Andrzej Tuchowski

Nationalism, Chauvinism and Racism as Reflected in

European Musical Thought

and in Compositions

from the Interwar Period

\title{
Volume 14
}

Eastern European Studies

in Musicology

Edited by Maciej Gołąb 
This book concerns the ways in which many different types of nationalism, chauvinism and racism penetrated into musical thought in the interwar period, and how the leading artistic personalities of that period reacted to these ideologies. The concept of "nationalism" is understood broadly in this book and covers the entire spectrum of its positive and negative aspects. The topics listed in the book's title have been discussed on the example of selected four countries, significant with respect to population and territory and representing different social-political systems: Germany (mostly after 1933), Italy, Poland (after 1926) and Great Britain. This selection is also representative of the main ethnic groups in Europe: Anglo-Saxon, Germanic, Latin-Romance and Slavic.

Andrzej Tuchowski, a musicologist and composer, is a professor of music theory at the Zielona Góra University and Karol Lipiński Music Academy in Wrocław. He specialises in the $19^{\text {th }}$ - and $20^{\text {th }}$-century music history and theory as well as in the socio-political aspects of music in the $20^{\text {th }}$ century. 
Nationalism, Chauvinism and Racism as Reflected in European Musical Thought and in Compositions from the Interwar Period 


\title{
Eastern European Studies in Musicology
}

Edited by Maciej Gołąb

\author{
Editorial board \\ Mikuláš Bek (Brno) \\ Gražina Daunoravičienè (Vilnius) \\ Luba Kyjanovska (Lviv) \\ Mikhail Saponov (Moscow) \\ Adrian Thomas (Cardiff) \\ László Vikárius (Budapest)
}

Volume 14 
Andrzej Tuchowski

Nationalism, Chauvinism and Racism as Reflected in European Musical Thought and in Compositions from the Interwar Period

Translated by Tomasz Zymer

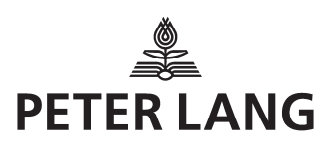




\section{Bibliographic Information published by the Deutsche Nationalbibliothek}

The Deutsche Nationalbibliothek lists this publication in the Deutsche Nationalbibliografie; detailed bibliographic data is available in the internet at http://dnb.d-nb.de.

Library of Congress Cataloging-in-Publication Data A CIP catalog record for this book has been applied for at the Library of Congress.

The Publication is founded by Ministry of Science and Higher Education of the Republic of Poland as a part of the National Programme for the Development of the Humanities. This publication reflects the views only of the authors, and the Ministry cannot be held responsible for any use which may be made of the information contained therein.

FOR THE DEVELOPMENT OF HUMANITIES

Printed by CPI books GmbH, Leck

ISSN 2193-8342• 978-3-631-78727-4 (Print)

978-3-631-79589-7 (E-PDF) • 978-3-631-79590-3 (EPUB)

978-3-631-79591-0 (MOBI) • DOI 10.3726/ b15888

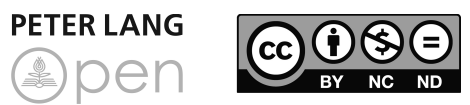

Open Access: This work is licensed under a Creative Commons Attribution Non Commercial No Derivatives 4.0 unported license. To view a copy of this license, visit https://creativecommons.org/licenses/by-nc-nd/4.0/

(C) Andrzej Tuchowski, 2019

Peter Lang - Berlin · Bern - Bruxelles · New York ·

Oxford $\cdot$ Warszawa $\cdot$ Wien

This publication has been peer reviewed.

www.peterlang.com 


\section{Contents}

Introduction

I. The National and Universal Dimensions of Music in the Aesthetic Thought of Ralph Vaughan Williams and Karol Szymanowski

II. The Racist Foundations of the National-Socialist Thought on Music

1 "Was ist Deutsch in Deutscher Musik?": Concerning the Germanic and Nordic Racial Features in German Music

2 'Judentum in Musik' - Around the Musical Activity of the 'AntiRace'

2.1 Organic Harmonic-Tonal Unity 74

2.2 The Organic Unity of Formal Structures 75

2.3 The Organic Aesthetic-Social Unity 77

III. Das Volk, die Volksgemeinschaft, der Volkskomponist: The Concept of the "Community of Blood" and the Debate Concerning National-Socialist Normative Musical Aesthetics

IV. Between Thought and Action: Nazi Racial Doctrines and the Consequences of Their Implementation in the Context of the Reactions of Europe's Music Circles in the 1930s

1 Journalism and the Music Environment in Interwar Poland: “... Far-Reaching Caution Is Recommended"

2 Protecting Elitism: Szymanowski, the Grand Polish 'Aristocratic' Traditions and the 'Jewish Question' 
3 The Polish "Rassenkunde": Józef Reiss and His Research on "The Jewish Spirit in Music"

4 Zofia Lissa: The Problem of Race in Music ........................................ 123

5 Chopin and the Question of 'Racial Purity' ........................................ 127

6 The Reactions of British Music Critics, the Appeasement and the British-German Policy for the Musical Cooperation of "Germanic Sister Nations"

7 The Ideological Counter-Offensive of British Great War Generation Artists - Pacifism against Racism and Chauvinism

81938 - The Breakthrough Year: Benjamin Britten's and Michael Tippett's Politically Involved Works in Relation to Events in the Third Reich

\section{The Italian "National Awakening" and Historical-Imperial Nationalism. Art in the Context of the Fascist Myth of Romanità}

1 Modern Art or Degenerate Art? Modernism and Its National Aspects in Fascist and Nazi Ideologies

2 The Musical Apologies of Rome in the Service of Fascist Imperial-Historical Nationalism

2.1 "Salve Roma divina!": Hymn to Rome by Giacomo Puccini 174

2.2 "Tutto che al mondo è civile, grande, augusto, egli è romano ancora!" Ottorino Respighi's Roman Trilogy and the Nationalist Musical Aesthetics of the Fascist Era 178

2.3 From Rimsky-Korsakov to Giannotto Bastianelli: Transformations in Respighi's Aesthetic Stance on His Way to the "National Revival"

2.4 Prophetic Aspects: The Roman Trilogy in the National and International Context

\section{From the Myth of Romanità to Fascist Racism: Italian Musical Thought in the Face of Political-Ideological} Changes in the late 1930s 
VII. The "New Rome" Clashes with the "Third Greek

Civilisation" - The Decline of the Myth of Romanità

VIII. Postscript: The Decline of Racism and Chauvinism, "Crypto-Nationalism" and the Demythologisation of Nationalist Concepts of Tradition after World War II ...... 215

1 "Crypto-Nationalism" and "National Musicologies" ....................... 218

2 From Nationalism to Universalism ...................................................... 221

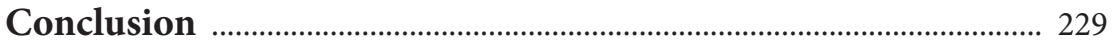

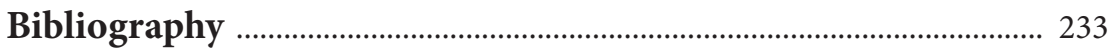

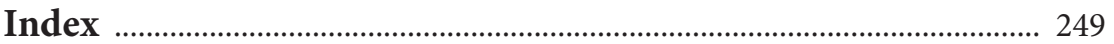





\section{Introduction}

The concept of "nationalism" usually does not evoke positive associations in Poland. Nationalist beliefs, views and attitudes are for the most part associated in articles on social and cultural subjects with unjustified claims concerning the superiority of everything that is "our own" over all things "foreign" or "alien", with feelings of aversion or at best suspicion toward other cultures, and with the desire to isolate one's own nation viewed as a kind of besieged fortress. In the West, on the other hand, nationalism is for many historians and journalists a neutral concept referring to a certain type of social-political and cultural awareness which developed in the early 19th century and was based on the conviction that the interests of a nation are superior to the interests of individuals, social groups and classes. This concerned first and foremost the problem of power and control since - as Anthony D. Smith ${ }^{1}$ observes - the key feature of all nationalism is the conviction that the nation is the most important, ultimate source of political power, which dominates over all other forms of legitimacy. One might well challenge this thesis by pointing to nationalisms that flourished in 19th-century imperial monarchies, such as tsarist Russia, which combined national messianism with the doctrine of the divine origins of the emperor's authority. However, in the reality of the 20th century, and especially in the face of the clear tendency to form ethnically tightly-knit and cohesive national states in the period between the two world wars (which we will herein refer to as the "interwar" period) - this thesis could well prove valid. Another element common to all forms of nationalism is a strong attention to, and emphasis on, the separate identity of one's own national traditions and culture, as well as the emotional affirmation of that identity, which sometimes leads to heated, emotionally charged debates concerning national subjects. Hence the not infrequent claim that nationalism and patriotism are in fact one and the same phenomenon. This claim, however, was criticised by Zygmunt Balicki (a leading Polish National Democracy or "Endecja" ideologist and activist) who claimed that - even though the two are indeed inseparable patriotism is a thing of the heart, and nationalism - of the brain:

"If patriotism is a national sentiment," wrote Balicki in 1912, "then nationalism is the thought of the nation, which - though it cannot be conceived and grow without this emotional foundation - is nevertheless a more complex spiritual phenomenon, since it

1 Anthony D. Smith, National Identity, (Reno-Las Vegas-London: University of Nevada Press, 1993), p. 74. 
presupposes the existence of at least some degree of organisation in the community, or in any event - some binding directives that determine public opinion. (...) Patriotism only concerns the sphere of the dispersed experience of internal states and external events by the masses, and spontaneous or emotional reactions to those states and events. But as soon as a central thought or idea appears in the nation, which aims to carry out some plans with regard to the nation's defence, strengthening and expansion - we already witness the appearance of the first germs of nationalism within a nation." ${ }^{2}$

The strategic priorities identified by Balicki as "the nation's defence, strengthening and expansion", corresponding to his concept of "national egoism"3 (from which many Endecja activists, including Roman Dmowski himself, distanced themselves at that time) prove that Balicki thought of national ideology primarily in "defensive-offensive" terms - which is understandable given the historical circumstances of that period. ${ }^{4}$ Statements in a similar vein were made - as we will further demonstrate - by numerous composers, music critics and writers commenting on the mission of national music in the first three decades of the 20th century. The said priorities notably correspond to Hans Kohn's ${ }^{5}$ vision of

2 Zygmunt Balicki, "Nacjonalizm a patriotyzm" [Nationalism and Patriotism], Przegląd Narodowy No. 5, May 1912, in: Z. Balicki, Wybór pism [Selected Writings], ed. Piotr .Koryś, (Kraków: Ośrodek Myśli Politycznej: “Księgarnia Akademicka”, 2008), pp. 412-413.

3 Balicki, Egoizm narodowy wobec etyki [National Egotism vs Ethics], (Lwów: Towarzystwo Wydawnicze, 1903). Balicki distinguishes rational and irrational altruism. The latter is characterised, among others, by a neglect of one's own national interest while acting in the service of other nations. "Our effeminate public can sense how little we can gain for ourselves from the hostile forces, and still it childishly prides itself on what we have done for others at our own expense" (p. 67). As an example of such irrational altruism in Polish foreign policies, Balicki quotes the Battle of Vienna (1683), which saved Austria - Poland's future partitioner, while the defeated Turkey would prove in the future to be "our natural and faithful ally" (p. 67).

4 Balicki stressed that "the struggle for assets between nations can no longer be limited to policing agreements and asserting property rights. It calls for a cultural campaign and for a high level of civic self-awareness on the part of all the groups and forces that constitute the nation" (Balicki, Nacjonalizm a patriotyzm, p. 414).

5 Hans Kohn, The Idea of Nationalism. A Study in its Origins and Background, (New York: The Macmillan Company, 1947). Kohn emphasises that - while in the past nationalism constituted "a great force of life", facilitating the establishment of civil liberties, at the time of his writing (i.e. in the early 1940s) "it may become a dead weight upon the march of humanity"(pp. 22-23). Generally Kohn distinguishes two types of nationalism: "civic/liberal", typical of highly developed Western countries (primarily the United Kingdom, France, and the United States), and ethnic-type nationalism characteristic of Germany and other Central and Eastern European countries 
historical transformations in European nationalisms during the 19th century. While the early-19th-century nationalism that developed mainly in Western Europe (described by Kohn as "cosmopolitan" or "open") was famous for its favourable disposition toward other nations, in the second half of the same century, nationalism in some countries paradoxically began to demonstrate arrogant, and finally - aggressive qualities as it transformed into its "closed" variety. While the first type of (for instance, Polish Romantic ${ }^{6}$ ) nationalism embraced the idea of international solidarity and acted as a positive factor that facilitated the integration of the international community, the other type - which rejected the concept of a community of different nations and demonstrated more or less arrogantly its superiority - turned out to be a potential threat. In this manner, nationalism may well transform into its degenerate form, tantamount to chauvinism, which inevitably provokes a defensive reaction in the neighbouring countries. Though Kohn (who refers mostly to German history) ${ }^{7}$ does present a certain model of historical transformations, one cannot help but notice that that the extreme types of nationalism he distinguished are also relevant as suprahistorical categories - as attitudes that are potentially present in every place and time.

As for assessing whether a given national ideology is considered to be nationalistic or rather chauvinistic - this depends largely on the commentator's political stance, as Roman Dmowski observed with considerable irritation in 1903. He claimed that the term "chauvinism" is abused and misinterpreted in Poland, mostly as a result of socialist propaganda. In the eyes of the socialists, Dmowski argued, even someone's conviction that "Polish songs work better on my soul than Dubinushka [Russian folk song]" is already chauvinistic. What is more - he adds maliciously as Endecja's chief ideologist - "for all kinds of Russophiles the

(pp. 329-356). Currently, however, such geographic-civilizational "attributions" provoke reasonable doubt since, among others, the ethnic element was also of considerable importance in the European West.

6 Andrzej Walicki observes that Polish Romantic nationalism and its intellectual component played a major role in 19th-century European history. Cf.: Andrzej Walicki, Philosophy and Romantic Nationalism. The Case of Poland, (Oxford: Oxford University Press, 1982), p. 3, Walicki, Naród, nacjonalizm, patriotyzm [The Nation, Nationalism, Patriotism], (Kraków: Universitas, 2009).

7 Cf. Kohn, The Mind of Germany. The Education of a Nation, (New York: Charles Scribner's Sons, 1960). 
term 'chauvinism' in the sense in which it is used by the socialists comes very handy indeed."

In his defence of nationalism against accusations of being chauvinistic, Dmowski eventually quotes the following, very apt argument:

"If chauvinism - as understood by every civilised person - is a blind belief in the virtues of one's own nation and its superiority over others, then please note that the democraticnationalist movement in Poland, like no other political option today, sharply criticises our national vices and looks for ways to overcome them, working more than anyone else in the educational field." 9

Dmowski was undoubtedly right here. His cutting retort reveals another line of division between "self-critical" nationalisms which aim to eliminate what is considered as the nation's vices, and "apologetic" ones, prone to the unquestioning mythologisation of everything "native". The Polish Romantic national thought was sometimes close to the latter stance. An extreme example of this is the messianic vision of Poland as "Christ of the Nations". Here one should recall the historical contexts of nationalisms and their interactions with other ideologies. The Polish nationalism of that era, rooted in the Romantic ethos of combat and fed by the cult of successive Polish uprisings, was in a way forced to mythologise and beautify its object because of the need for strong national integration. It was meant to motivate the nation and then to take up arms. This type of nationalism depended more on elements of "propaganda of war" than on long-term educational processes and their effects. Endecja's nationalist ideology - highly critical of revolutions and rebellions and embracing many of the positivist ideals - as well as the pro-European, modernist nationalism of Young Poland (as represented by Przybyszewski ${ }^{10}$ ) developed in different conditions altogether. Characteristically, notwithstanding their different viewpoints and spheres of activity, Dmowski, Balicki, Szymanowski, Karłowicz, Przybyszewski and Paderewski all postulated a modernisation of Polish economy, culture and national mentality. They recommended education and systematic work rather than armed campaigns as a remedy for civilizational backwardness. Even though Polish nationalism was

8 Roman Dmowski, "Szowinizm (November1903)”, in: Dmowski, Pisma [Writings], vol. 3, Diesięć lat walki [Ten years of struggle], (Częstochowa: Antoni Gmachowski i S-ka, 1938), p. 120.

9 Dmowski, Szowinizm, p. 121.

10 Stanisław Przybyszewski, Szopen a naród, [Chopin and the nation], (Kraków: Spółka Nakładowa "Książka", 1910), also c.f. Prszybyszewski: Szlakiem duszy polskiej [The trail of Polish soul], (Poznań: Spółka Nakładowa "Ostoja”, 1917). 
prone to exaltation, to a mythologisation of the Commonwealth's history and an apology for its heroic achievements - its pioneers were also capable of more profound thought which frequently anticipated the ideas of later theoreticians and historians of that ideology. The very fact that Mochnacki and Libelt - the founders of Polish nationalist ideology in Chopin's time - asked questions such as "What is a nation?" - places them in the avant-garde of more profound nationalist thought. Mochnacki's answer anticipates in fact the conclusion made by a contemporary theoretician of nationalism, Ernest Gellner, that nationalism creates the nation, and not vice versa. ${ }^{11}$ This observation is prefigured in Maurycy Mochnacki's definition of a nation:

"...a nation is not merely the sum total of people inhabiting a certain area delimited by some borders. The essence of a nation is the collection of all its ideas, concepts and sentiments related to religion, political institutions, law and customs, and even closely connected with geographic context, climate and other empirical conditions of life."12

The thusly defined "essence of a nation" leads to the necessity "to accept oneself in one's own being" and to confirm this "acceptance" in written testimony and works of art, in other words - in the form of "moral, mental and aesthetic" representations. If such national self-awareness, confirmed by the said testimony (which Gellner identifies with nationalist thought) does not manifest itself the nation remains a mere collection of individuals "like particles of matter loosely connected by mechanical principles, which can easily be pulled away and separated by mechanical means."

As mentioned above, similar questions were asked by Karol Libelt - a Poznańbased philosopher and pupil to Hegel himself. Libelt agreed with his colleague from Warsaw as to the importance of "shared ideas, sentiments and concepts" for the essence of a nation, and he emphasised the fundamental role of high-quality literary works in the process of confirming the former. In his definition of a nation, however, Libelt places his accents differently from Mochnacki. Nations are, he claims, a natural phenomenon and each of them carries out its own mission given to it by God, which is identical with the aspiration for "progress, freedom, and light." Libelt emphasises the significance of historical and communal contexts for the formation of a nation. He concludes that the very notion of a nation (Polish naród) derives from the word for "clan" or "family" (Polish ród),

11 Ernest Gellner, Nations and Nationalism, (Oxford: Blackwell, 1983), pp 48-49.

12 Maurycy Mochnacki, O literaturze polskiej w wieku XIX [On Polish Literature in the 19th Century], ed. Henryk Żywczyński, (Kraków: Krakowska Spółka Wydawnicza, 1923), p. 35. 
and thus it points to the tribal and familial roots of every nation. Crucial for the emergence of Polish nationhood were the historical moments of inducting unrelated families into the same Polish coat-of-arms (thus forming heraldic clans) which was done for the Lithuanian nobility by King Władysław II Jagiełło, and for the Ruthenian nobility by King Władysław IV. In this way, Libelt claims, "families of different tribes were united into one set of clans, like tributaries flowing into one main river of history." ${ }^{13}$ Finally Libelt claims, making use of a musical metaphor, that the ethnically heterogeneous regions of the old Commonwealth were united into one organism, like "variations in which a person can hear one and the same melody, imbued with the spirit of the nation - and this unity, this melody, depends on the community of clanship." ${ }^{14}$ Thus for Libelt the dominant nation-building factor is the historical community of clans, which explains the identification of the Polish "nation" with the nobility (before the 18th-century partitions of Poland). In this sense, a Lithuanian or Ruthenian nobleman is a part of the Polish nation (even regardless of the language of everyday communication) more than an ethnically Polish burgher or peasant.

Even though both of the above-quoted definitions concern Polish national thought, the differences between them can also be considered on a more universal level. They illustrate the multiplicity of definitions of a nation, some of which focus on the historical and/or social-class community, while others point to the community of language, culture, territory, race, etc. For this reason, as John A. Hall has amply demonstrated ${ }^{15}$, one universal theory of nationalism cannot be formulated. All classifications of nationalisms are vague and sometimes even dubious. Except for the extreme examples, it is also frequently not easy to clearly distinguish nationalism from chauvinism. Apart from the abovementioned political context, the subjective intention of the following /or/ aforementioned author should also be considered.

In order to apply the above considerations to the world of music, one could well ask whether the title of Józef Reiss's well-known publication "Polish Music is Most Beautiful of All" proves that its author was a chauvinist. One could make that argument if he had used his musicological expertise and analytic-critical skills to prove the thesis contained in this statement by means of a comparative

13 Karol Libelt, O miłości ojczyzny [On Love for the Fatherland], (Brody: Feliks West, 1907), p. 43.

14 Libelt, O miłości ojczyzny, p. 40.

15 John A. Hall, "Nationalisms: classified and explained", Deadalus, Summer 1993, No. 3, p. 1. 
study of the music of Poland with other nations. However, the same title can also be interpreted as a type of "mental shortcut". In the subjective view of the author as a patriot, Polish music simply sounds most beautiful, independent of the possible intersubjective opinions of the international music community. The same can be postulated concerning the message contained in (the former first stanza of) the German national hymn Deutschland über alles. That Germany is the highest value for German patriots, priced above "everything in the world", only confirms their praiseworthy patriotic sentiment without precluding the possibility of retaining a friendly and positive attitude toward other nations. However, once one begins to interpret the phrase über alles in der Welt as plain belief in the superiority of one's own nation over others - the chauvinistic character of such a proposition becomes unquestionable.

"Open", positive nationalism could often be the driving force and a creative stimulus for culture - as exemplified by the works of composers belonging to various national schools. Racism, on the other hand, left a negative mark on history, not only in the form of the once common call for racial segregation in public life, but also as the deceptive and dangerous "science" appropriated by the Nazis, which led in the 20th century to genocide on an unprecedented scale. However, racism also manifested itself in many different variants (cultural, biological, colonial-type, etc.), thus it seems reasonable that we should follow Claude Levi Strauss's rather broad definition: "Racism is a doctrine that claims to see the mental and moral characteristics of a group of individuals (however the group may be defined) as the necessary effect of a common heritage." 16 This definition accurately identifies the gist of the racist doctrine and can constitute a point of departure for a study of its consequences and their scale. Also in this case, there is a notable difference between the doctrine itself (consisting of relatively harmless academic speculations reflecting the current state of knowledge) and the results of putting this doctrine into practice. One could also distinguish different forms of racism, some causing less (or some more) evil. What we must not do, however, is apply our present-day civilizational standards and state of knowledge to past periods and assess the attitudes and achievements of the previous generations on the basis of our current standards and knowledge. Just as 19th-century academic medicine saw "impure blood" as the cause of tuberculosis - which led to the application of blood-letting as a form of therapy ${ }^{17}$ - so also for 19 th-century

16 Claude Levi-Strauss, The View from Afar, English transl. by Joachim Neugroschel and Phoebe Hoss, (Chicago: University of Chicago Press, 1992), p. XIV.

17 Chopin's sceptical attitude to the academic medicine of his day is believed to have significantly prolonged his life. One should also recall Adam Grobler's warning that in 
anthropology the inequality of human races was something obvious, and it affirmed the mental superiority of white people while possibly accepting that dark-skinned ones may be physically stronger and fitter. Some educated people such as Josiah Clark Nott, a 19th-century physician from the Southern United States - even entertained the idea that people of African descent may be the link between the animal and the human worlds, which resulted in accepting slavery as a "natural" state. ${ }^{18}$ Seeing the qualities of various human groups as the inevitable consequence of their common genetic heritage led to a hierarchical view of humanity which frequently sanctioned the authority of a "racially superior" group over the other groups.

From the early 20th century onward, this doctrine also began to incorporate more and more frequently, divisions within the globally dominating white race. Thus conceived, racism reached its peak in the interwar period, when two types of racism co-existed. These two differed in the attitude of the "dominant" race toward the "inferior" races. The first type, which we may label as "pragmatic", aimed at a co-existence of races based on submission, segregation and exploitation, but also - for instance in the case of British colonial racism - on missionary, educational and civilizational activity directed toward the subordinated peoples. The other, "fundamentalist" type - characteristic of Nazism - aimed solely at ruthless exploitation or at extermination.

If we accept the statement (attributed to Einstein) that nationalism is "an infantile disease (...) the measles of mankind" - then it follows that probably the most dangerous of those "diseases" was racism itself. It is also evident that the two decades that separated the two world wars were - to extend Einstein's medical metaphor - the years of a veritable "epidemic" of such "maladies", of which humanity seems not to have been aware for the most part. The political situation facilitated their development. The newly created or revived countries

each age knowledge is only a collection of opinions held at a given point in time. We should be able to abandon those opinions and beliefs as soon as more credible opinions have appeared. Cf. Adam Grobler, Pomysly na temat prawdy [Concepts Regarding Truth], (Kraków: Aureus, 2001), p. 53.

18 In the 1840s Nott compared human skulls of various races and came to the conclusion that the structure of black-skinned people's skulls determined their lower level of intellectual faculty. He also held the opinion that slavery (understood as a kind of "human farming") provides the optimum conditions for black people to prolong their lifespan and develop both physically and mentally - better than in the free state. Many people shared Nott's views at that time. Cf. Jerzy J. Wiatr, Zagadnienia rasowe w socjologii amerykańskiej [Racial Issues in US Sociology], (Warszawa: PWN, 1959), p. 18. 
exploited their (authentic or reinvented) traditions of national culture, which gave credence to their political presence, while nationalist sentiments were also rising in the countries traditionally considered as the great European powers. In the defeated Germany nationalism evolved into chauvinism, which was accompanied by a brutal struggle against left-wing forces, which were growing in strength. In the victorious Great Britain, nationalism was an integrating factor which counteracted the disintegrating tendencies in the British Empire. Italy also victorious, but left with a ruined economy- was experiencing the euphoria of a "national revival" under the influence of a (politically manipulated) nostalgia for the lost Roman-imperial roots. All these phenomena were influenced by the Great Depression, by problems with national minorities, by widespread faith in the efficacy and smooth functioning of ethnically uniform national countries, and in the progress of technology and science. The latter raised hopes that suitable state policies combined with eugenics could improve the quality of the "race" and help create a healthier, stronger, and physically and mentally fitter population. The former (owing to the popularisation of the radio and to the mass impact of the cinema) opened up previously unknown possibilities for state propaganda intending to manipulate public opinion. The huge potential of this propaganda manifested itself in the (also previously unknown) totalitarian systems. By applying censorship, the systems took care to eliminate from public space all ideas, views and attitudes that could compete with those officially advertised.

This collection of studies concerns the ways in which many different types of nationalism, chauvinism and racism penetrated into musical thought in the interwar period, and how the leading artistic personalities of that period reacted to these ideologies. The concept of "nationalism" is understood broadly in this book and covers the entire spectrum of its positive and negative aspects. The book discusses 20th-century schools of composition that emerged on the wave of patriotic enthusiasm at periods of "national revival", aesthetic systems tinged with national ideas, the relation between "rooting in one culture" and universal values, as well as historiosophic concepts that upheld the given nation's claims for a hegemonic position. Our studies also deal with chauvinist propaganda in totalitarian states. The negative, chauvinistic type of nationalism degenerated - in extreme cases (such as the Third Reich and fascist Italy) - into racism.

In order to respect Maciej Gołąb's ${ }^{19}$ postulate of subjecting historical studies to theoretical rigour, and because of the impossibility of creating one comprehensive

19 Maciej Gołąb, Musical Modernism in the Twentieth Century. Between Continuation, Innovation and Change of Phonosystem, (Frankfurt am Main: Peter Lang, 2015), pp. 14-15. 
theory of nationalism (already signalled above, and demonstrated by John A. Hall), we have adopted the method of presenting the topics listed in the book's title on the example of selected major countries, significant with respect to population and territory and representing different social-political systems.

Our selection is justified by the fact that the extent to which the said ideologies could function in public life depended on specific systems of authority and on limited freedom of speech. In democratic countries they had to compete in public with other concepts, and the debate was in no way limited by the state. In totalitarian countries the situation was diametrically different. There, those ideologies were the main instrument of control over the masses and the foundation of state propaganda. For the subject of our studies we have selected exclusively European countries, representing cultures based on Greco-Roman civilizational foundations and shaped by the Western forms of Christianity (Catholic and Protestant). I assume that a highly representative image of the phenomena in question can be derived from the study of Germany (mostly after 1933), Italy, Poland (after 1926) and Great Britain. This selection provides us with a full palette of political systems from "absolute" totalitarianism (the Third Reich) to "relative", less oppressive totalitarianism, somewhat operetta-like in character (the fascist Italy), to authoritarianism with a wide margin of preserved civil liberties (the 2nd Polish republic after $1926^{20}$ ), to full pluralist democracy with guaranteed freedom of public speech (Great Britain). This selection is also representative of the main ethnic groups in Europe: Anglo-Saxon, Germanic, Latin-Romance and Slavic. Moreover:

20 Hannah Arendt classified the 2nd Polish Republic as a country governed by a "non-totalitarian dictatorship", listing Poland along with Mussolini's Italy, von Horthy's Hungary, General Franco's Spain, and others. Cf. H. Arendt, The Origins of Totalitarianism, (San Diego-New York- London: Harcourt, Brace \& World, 1979), pp. 308-309. Admittedly the only fully democratic state in this part of interwar Europe was Czechoslovakia. However, putting Poland in one category with fascist Italy and Spain raises considerable doubts, especially when we compare the scope of freedom of speech and other civil liberties in pre-war Poland as opposed to the other countries. The scale of state bureaucracy and censorship was also different, as confirmed by excerpts from the Polish 1930s press quoted further in this book, which - as in the case of the Endecja opposition party organs - were frequently critical toward the authorities. Polish censorship mostly focused on eliminating all texts that "defiled" the memory of Marshall Józef Piłsudski or promoted communist ideology, including calls to incorporate Poland into the Soviet Union. In the interwar Poland, unlike e.g. in fascist Italy, the official state propaganda was far from omnipotent. 
- two of the selected countries were undoubtedly superpowers (Great Britain and Germany), while Italy and Poland aspired to this kind of status.

- Germany and Italy were traditional historical leaders of musical development, while Poland and Great Britain worked hard to "catch up" and to form their own solid, national schools of composition.

- The 3rd German Reich was the only country in that period which (from its inception in 1933) began to implement racist doctrine in all areas of life (including music history and theory) and used it as the foundation of official ideology, gradually combining Great German chauvinism with biologicaltype racist ideology.

- Fascist Italy provides the only, unique example of ideological evolution from a relatively "open" ethnic nationalism to historical-imperialist nationalism, to racism.

- Interwar Poland and Great Britain were multinational countries dominated by "leading" national cultures - respectively Polish and English. These internal relations had an impact on the specific character of nationalism in these two countries and (particularly in Poland) - on the various types of anti-Semitism, which, however, seldom turned strictly racist in character. Importantly, it was in England in the late 1930s that "politically involved" music compositions appeared, expressing protest against chauvinism and racism as well as against the violence inevitably generated by these ideologies (Michael Tippett, Benjamin Britten).

- England, Italy and Poland all boasted major artistic personalities in that period (Ralph Vaughan Williams, Ottorino Respighi, Karol Szymanowski). At a similar time and age (around forty), though in different circumstances, these composers experienced their "national awakening" and became the icons of their own respective music schools.

In each case, the study of the impact that nationalism, chauvinism or racism exerted on broadly conceived musical thought is presented against a wide panorama of political and social, as well as general, cultural contexts, also including mutual interrelations between the countries under study as well as the influence of ideas and cultural policies developed in those countries on other regions in Europe. The book ends with an extensive Postscript which presents the scope of the influence of the rudiments of nationalism and its latent forms on the music of the second half of the 20th century - the period of gradual international integration. We will dedicate attention not only to the ideological contexts of musical historiography, criticism and theoretical thought, but also to the ideas and practice of leading composers from the selected countries. Each of them 
reacted to the surrounding reality in their own individual way. Nevertheless, we can find a certain common ground in their opinions, attitudes and statements, which can be attributed to the "spirit of the age". In each case, however, it will be the author's aim to reconstruct the atmosphere of those times and places, and to understand them rather than passing any judgments or opinions. It is frequently all too easy to pass judgments from the perspective of our present-day historical knowledge. 


\section{The National and Universal Dimensions of Music in the Aesthetic Thought of Ralph Vaughan Williams and Karol Szymanowski ${ }^{21}$}

State histories can hardly be more different, it might seem, than those of Poland and England in the last three hundred years. England - the dominant nation of the United Kingdom - created history's greatest empire during those years, implemented an industrial and scientific revolution of global significance and transformed the cultural landscape in a large portion of the world, which has had lasting consequences until now. Poland, which used to be the dominant nation of the old Polish-Lithuanian Commonwealth - lost (in political terms) all that an erstwhile empire could lose, becoming a symbol, a tragic victim of shameful conspiracy for some, or a loser of its own making for others. Thomas Carlyle, an influential British philosopher and historian and author of the very popular (and dear to the Victorian establishment of the empire) ideology which claimed that "the strongest are right" - characteristically opted for the latter assessment of Poland's fall. The fate of the Polish-Lithuanian Commonwealth was for him a model example of a state that suffered a catastrophe due to the moral decline of its elites. Once moral disintegration had reached a certain critical point, he claimed, the state as a representation of the nation is doomed to fall, whereas the nation itself will be subordinated to another, stronger one which derives its strength from moral principles, and is therefore protected by Divine Providence. Today such a historiosophic paradigm requires no commentary. Curiously, in line with this reasoning not only Prussia, but also the tsarist Russia was a model of virtue. All the same, one should stress the importance of this view for the development of 19th-century English nationalism ${ }^{22}$ and its specific qualities, the

21 This chapter is an extended version of an article published in: Karol Szymanowski w perspektywie kultury muzycznej przeszłości i współczesności [Karol Szymanowski in the Context of Past and Present Musical Culture], ed. Zbigniew Skowron, (WarszawaKraków: Musica Iagellonica, 2007), pp. 49-78.

22 Hans Kohn stresses the supra-historical stability of English nationalism, whose qualities developed as early as the 17th century, and whose religious and liberal character stemmed from the awareness of the common roots of political and religious freedom in England. According to Kohn, English nationalism, invariably emphasising individualism and placing the human community above national divisions, had a strong impact on the character of British 19th-century imperialism. Cf. Kohn, The Idea of Nationalism, pp. 178-179. 
most prominent of which was its undaunted triumphalism. Donald Read quotes examples of opinions ${ }^{23}$ which can be seen as a kind of Victorian creed, such as: "one Englishman can beat two foreigners", "the English fiscal system is the best in the world", and "our men of business, when they take the trouble to excel, are without rival in the world." These and similar views, rooted in the unquestionable civilizational success of the English nation, supported the claim that the Providence has extended special protection over the British Empire. At the same time, however, such opinions blurred the distinction between what was British and what was ethnically English (the same was true about opinions concerning Poles in the old Polish-Lithuanian Commonwealth).

Naturally, the differences in historical conditions also determined the different shape of Polish national thought. Still, paradoxically, there was also a marked element of triumph in Poland - a moral one, albeit tinged with bitterness. Dmowski wrote that the nation's tragedy was not always viewed as a downfall. Poles were never able to stoop to the cynically treacherous ways of international policy, which made many a state into an empire. ${ }^{24}$ Despite a hundred years of life under foreign rule (in the partitioned Polish territory), Polish culture survived and battle-hardened - can now stand every trial. Naturally, the Romantic tradition in Polish national thought (as represented by Mochnacki, Mickiewicz, Słowacki, and Towiański), as well as their early 20th-century successors - based its ideology on an idealised vision of the nation's history. Also present, however, was space for the workings of Divine Providence. Despite the nearly blasphemous criticism contained in Chopin's Stuttgart diary and in Mickiewicz's Forefathers' Eve, the dominant view was that the nation, deprived of its own state, nevertheless enjoys special divine protection that will ensure its survival. Poland was still to play its unique role in history as the "Christ of Nations". Being a nation - observed Ernst de Renan in $1882^{25}$ - involves shared experiences and

23 Donal Read, Edwardian England, (London: Harrap, 1972), pp. 15-16.

24 Cf. Roman Dmowski, Myśli nowoczesnego Polaka [Thoughts of a Modern Pole], (Kraków: Towarzystwo Wydawnicze, 1904). Dmowski quotes this view as characteristic of the anachronistic nature of Polish 19th-century national ideas and of how far they diverged from the realities of life. He ironically comments on the popular opinions that violence and treason as the foundations of Prussian policy must lead the German nation to a future catastrophe. While his criticism of the Polish national vices was accurate, in his views on the prophecies of the Romantics concerning the future of Germany - he was proved to have been wrong.

25 Quoted after: Eric J.Hobsbawm, Nations and Nationalism since 1780: Programme, Myth, Reality, (Cambridge: Cambridge University Press, 1990), pp. 12-14, cf. also: Anthony D. Smith, Nationalism and Modernism, (London: Routledge, 1998), p. 10. 
memories, but also shared "forgetfulness". A tendentious approach to the history of one's own nation is a constitutive feature of the phenomenon of national historical memory. Still, it was history (albeit frequently reduced to mythology) that constituted the driving force of 19th-century national thought both in Poland and England. Both nations derived their characteristic sense of pride from history: Poles - from past achievements and the conviction about their own moral superiority; Englishmen - from current successes seen as the effect of England's moral prowess which earned her the support of Divine Providence.

Historical character is contained, in a sense, in the very etymology of the word 'nation'. As stressed by E.J. Hobsbawm ${ }^{26}$, the Latin natio refers to the source or origin; the same is true about the Slavonic naród (from ród - the clan, the progeny), as the already quoted Karol Libelt observed. However, Antony D. Smith ${ }^{27}$ stressed that national thought and theoretical reflection on the phenomenon of nationalism need not focus on common origins, which are the subject of a broadly conceived history. Contrary to appearances - as we have already signalled before - the idea of a 'nation' is an ambiguous one and its semantic content depends on its context: philosophical-ethical (the nation and national identity as an absolute value or as a means to securing other values), political and anthropological (the rules of the relationship of nation vs. individual; the social principle of national community), and historical (the place of the nation in history; its 'roots' in the history of culture). From this point of view, the ethnic-cultural criterion is (along with an idealised vision of history) dominant both in English and Polish traditions. In both cases, the turn toward a historical mythology of the nation received support in the form of works of art, and music played a vital role here. In England - largely thanks to Ralph Vaughan Williams - it was, as I will demonstrate below, the music of the Tudor era, and in Poland - obviously the works of Chopin.

It can be viewed as a paradox that in such radically different historical, geopolitical and (especially) economic circumstances, the history of Polish and English music went through similar phases, experiencing its heyday and its decline in the same periods. In both countries, the 16th century has customarily been referred to as 'the golden age' when musical culture flourished, and both experienced a musical 'renaissance' with the onset of the 20th century, after two centuries of stagnation. The phenomenon of Chopin does not fit into this picture of parallel music development - but the English could balance the account with the

26 Hobsbawm, Nations and Nationalisms, p. 15.

27 Smith, Naional Identity, pp. 10-11. 
appearance of Handel a hundred years earlier. Though of German descent, he nevertheless contributed greatly to the music tradition of England. Chopin wasas Szymanowski was the first to point out - a brilliant exception in the context of Polish culture in his age. "He did not remain in any organic relation with that culture, had neither predecessors nor successors, and was almost paradoxical in his 'singularity' - a bright lone star amid the night." ${ }^{28}$ Szymanowski's critical remarks on the condition of music culture in Polish territories find their striking counterpart in the writings of George Bernard Shaw and Ralph Vaughan Williams, though the motivation was obviously different in either case. In 1919 Shaw wrote:

"And we are a people of low pleasures because we are brought up to them: the British workman finds the public-house and the football field offering themselves to him insistently at every turn; and the British gentleman is actually forced to spend his boyish leisure at cricket and football before he enters an adult society in which he cannot escape hunting, shooting, bridge, and billiards, though he can go through life as a complete gentleman without hearing a Beethoven sonata in any other form than that of a disagreeable noise which he forbids his daughters to make in the schoolroom except during the hours when he is usually out of doors. If you eliminate smoking and the element of gambling, you will be amazed to find that almost all an Englishman's pleasures can be, and mostly are, shared by his $\operatorname{dog} . . .29$

Vaughan Williams wrote in a similar spirit, though without Shaw's sharp tongue. He claimed that from the 18th century onward, when political power in England had been taken over by the entirely uncultured gentry, the practice of art came to be regarded as "unworthy of a gentleman's time." 30

In the history of music, the late 19th and early 20th centuries were for both nations the time to "catch up on the backlog", especially in the field of symphonic music. This revival took the form (common to both nations, in a sense) to (as Karłowicz put it) "snatch the knowledge from the Germans." In both England and Poland, the 20th century brought world-class artistic personalities and schools of composition which enjoyed a well-established international position. By a strange twist of fate, the two greatest authorities in the field, now

28 Kornel Michałowski (ed.), Karol Szymanowski, Pisma muzyczne [Karol Szymanowski, Writings on Music], (Kraków: PWM, 1984), p. 40.

29 George B. Shaw, "The Future of British Music", The Outlook, 19th July 1919. Quoted after: Louis Crompton (ed.), The Great Composers. Reviews and Bombardments by Bernard Shaw... (Berkeley: University of California Press, 1978), pp. 360-361.

30 Ralph Vaughan Williams, National Music and other Essays, (Oxford: Oxford University Press, 1987), p. 4. 
already considered as classics in both countries - Benjamin Britten and Witold Lutosławski - were born in the same year. The greatest similarity, however, we can discern in the work on behalf of national music undertaken by Karol Szymanowski and Ralph Vaughan Williams - the two artists whose contribution to their respective musical cultures can hardly be overestimated. They represent the generation that entered the music scene early in the 20th century.

Ralph Vaughan Williams's life (1872-1958) was much longer than Szymanowski. 10 years older than the latter composer, he also outlived Szymanowski by 21 years. He was a man of a strong mental and physical constitution, leading a regular, respectable life free from any social scandals or excesses that were typical of the bohemian artists who Szymanowski closely associated with. Like Szymanowski, he impressed people with his cultured manner, versatile interests and profound erudition. Unlike the master from Villa Atma (who was a brilliant autodidact), Vaughan Williams studied at Britain's most renowned universities.

Stylistically and in terms of technique, the two composers had little in common. Szymanowski's style was dominated by his modernist fascinations, while Vaughan Williams's musical language was shaped by a nostalgia for the past and by cautious attempts to modernise tradition. Nevertheless, both artists' styles developed in similarly meandering fashion and in the same direction - toward national music. In the interwar period they had in common not only their fascination with folk scales, rhythms and a 'folkish' type of sound, but also their considerable activity as writers, teachers and organisers. Both passionately engaged in the promotion of the ideology of national music, which they understood in a similar fashion - as their publications from that time also confirm. Their musical nationalism was quite devoid of any chauvinistic elements. Moreover, national music was for them an organic part of a greater whole termed European musical culture, with which they felt close ties, although each of them understood that culture in his own way. Both also expressed their concerns about the domination of German culture, which had previously been very close to their hearts.

What is evident in the writings of both composers is their fervent dedication to the cause of national cultures, and the emotional character of their discourse, which reminds one of the Romantic roots of both artists. This also found its reflection in their music, which through all of its stylistic stages preserved a Romantic type of expression, particularly in the form of ardent, emotionally intense lyricism. It would be interesting to examine in this context the question of possible communication between the two, or their opinions about each other's work. In the interwar period, as we know, Szymanowski spoke warmly of England, of its 
culture and civilizational achievements, also making positive comments about the evident revival in British music. He quoted the names of Arnold Bax and Arthur Bliss in this context, but there was no mention of Vaughan Williams, and he made the following reservation: "I do not have too much confidence in the musical talents of the Anglo-Saxon race." ${ }^{31}$ As for Vaughan Williams, from among Polish composers he mentioned only Chopin, whom he valued highly, though it would not have crossed his mind (and in fact nobody else's mind in England) that Chopin could be placed on par with the German masters, as in Szymanowski's writings. Even though both composers' works (Szymanowski's Kurpie Songs and Vaughan Williams's Benedicite) were performed at the same concert at London's Queen's Hall (on 28th July 1931 at the 9th annual ISCM Festival), Szymanowski did not visit London on this occasion. There is no information from available sources about any mutual contacts, which supports the supposition that the two composers never met in person.

Szymanowski's and Vaughan Williams's views on the issue of national music can be gleaned, as I have said, from their articles and interviews published during the interwar period. In Szymanowski's case these texts have been collected in volumes containing his musical and literary writings ${ }^{32}$, while for Vaughan Williams the main source of his opinions on this matter is his book National Music ${ }^{33}$, published in 1934 and comprising his new editions of lectures that he had delivered in the USA in the early 1930s. Szymanowski's 'conversion' to the national cause was, as we know, rather sudden and very likely related to his "intoxication with Polish freedom" and the related surge of patriotic sentiments. With Vaughan Williams, the situation was more complex. His views on national music crystallised gradually over many years, in connection with such factors as the disappearing ethnically English folklore (from 1903) and with his growing fascination for the musical traditions of the Anglican Church. These inspirations coincided with a change in English national thought that took place at the turn of the century and was stimulated by the political situation.

31 Cf. Michałowski (ed.), Karol Szymanowski, p. 61.

32 Michałowski (ed.), Karol Szymanowski, Teresa Chylińska (ed.) Karol Szymanowski, Pisma literackie [Karol Szymanowski, Literary Works], (Kraków: PWM, 1984).

33 Oxford University Press, London 1934. Two extended editions of the book were published after World War II, containing Vaughan Williams's articles written both before and after 1934: National Music and Other Essays (OUP, Oxford 1963) and the second revised edition (under the same title), which included publications omitted from the 1963 version, printed over a period of fifty years (OUP, Oxford 1987). 
The ever increasing economic expansion of Germany and the USA from the 1880s onward had shocking economic consequences for the Brits, and forced them to abandon the triumphalist rhetoric that derived British national superiority from their civilisational success. Germany was becoming a great military power as well, which made the claim that "the strongest are always right" rather risky. Additionally, internal unrest threatened the unity of the British empire. Thus, a new type of nationalism emerged, based on the primacy of cultural values, which attached much importance to England's pre-industrial art and folklore. Because of the special role of the latter, British historians refer to that ideology as ruralist nationalism ${ }^{34}$.

The phenomenon of cultural nationalism - specifically in relation to music composition - is obviously the subject for a separate study. According to Leon Plantinga ${ }^{35}$, in the 19th century it developed mostly in countries struggling for their independence, among the so-called developing nations, and in the context of a sense of cultural inferiority to other nations. None of these can explain the appearance of this phenomenon in England. As stressed by E. J. Hobsbawm ${ }^{36}$, nationalism can arise both spontaneously, as a 'grassroots' movement, or it can be steered 'from above'. In the case of nationalisms present in great empires, the latter situation is more common, since imperial power and conditions for further expansion need to be maintained. This, then, was the aim of the Slavophile messianism in Russia and the usurpation of the role of the heir to the Roman Empire by both the German Reich and Russia ${ }^{37}$. England for obvious reasons could not claim this kind of role, whereas the awareness of economic and civilizational achievements and of the wide civic freedoms stopped functioning in the British Empire as an integrating factor. It was then that the British elites accepted the claim that - for the sake of maintaining social and moral order - the sense of national identity had to be reinforced through a wider dissemination of patriotic behaviour models. Both English history and ethnic folk culture were

34 Alain Frogley, "Constructing Englishness in music: national character and the reception of Ralph Vaughan Williams", in: Alain Frogley (ed.), Vaughan Williams Studies, (Cambridge: Cambridge University Press, 1996), pp. 10-12.

35 Leon Plantinga, Romantic Music, (New York: Norton 1984), p. 400, quoted after: A. Frogley, "Constructing Englishness", p. 7.

36 Hobsbawm, Nations and Nationalism, pp. 10-12. Hobsbawm defines this 'down-up' nationalism as 'popular protonationalism'.

37 Cf. Hans Kohn, Reflections on Modern History, (Princeton: Van Nostrand Company, 1963), pp. 133-135. 
therefore idealised and opposed to the demoralised modern life of great industrial cities ${ }^{38}$. The rhetoric of a collective "spirit of the nation" (also found in the writings of Vaughan Williams) dates from that time. It was claimed to be most strongly present in folk songs. In British writings this rhetoric was influenced by Herder and $\mathrm{Hegel}^{39}$, but the analogies to the ideology of the völkisch movement (popular among the German intelligentsia in the 19th century) are more evident. Also in Germany, this ideology was (as I will demonstrate later) employed for social-political ends. On the other hand, not without significance for the growing interest in the vanishing folklore were (according to Percy M. Young ${ }^{40}$ ) pro-socialist sentiments that gained followers among British intellectuals, which found its expression, among others, in the tendency for the tastes of the lower and higher social strata to 'level off'. This was also true of Vaughan Williams, who demonstrated his ability to combine such seemingly contrary ideologies as socialism and nationalism. In his country he was no exception. ${ }^{41}$

How did Vaughan Williams's aesthetic views and artistic preferences evolve? As in the case of Szymanowski, their paths to the 'discovery' of national music traditions led through periods of enchantment with German and French music. It began with a youthful fascination for Wagner, which was characteristic of their generation. Later, in the 1890s, already as Parry's pupil at London's Royal College of Music, Vaughan Williams added Bach, Beethoven and Brahms to the list of his beloved masters. This was obviously the influence of his teacher. Parry, known for his conservative-academic and Germanophile tastes, was an ardent devotee of Brahms, who enjoyed great esteem in England at that time. As evident from a

38 England was most advanced in terms of urbanisation and industrialisation of all European countries at the turn of the 19th century. In 1914 only $14 \%$ of the British population were employed in agriculture, while in Germany that figure amounted to $33 \%$, and in France - to 43 \%. Source: Percy M. Young, A History of British Music, (London: Ernst Benn, 1967), p. 545.

39 Cf. Frogley, “Constructing Englishness", p. 11.

40 Young, A History, p. 545.

41 The composer's friend Bertrand Russell, a descendant of one of England's most prominent aristocratic families, also had leftist views. A. Frogley emphasises that this peculiar synthesis of nationalism, socialism, and even imperialistic ideology corresponded very well to the ideological make-up of the British elite in the early 20th century (Cf, Frogley, “Constructing Englishness”, pp. 12-13). This opinion was also confirmed by Hans Kohn, who suggested that the specific character of the dominant type of insular socialism, different from parallel developments on the continent, was largely due to the strong impact of English nationalism on that ideology, cf. Kohn, The Idea of Nationalism, p. 178. 
letter written to his cousin and fellow student at Cambridge, Ralph Wedgwood, in the autumn of 1897, Wagner still remained the young composer's greatest idol. When asked by his cousin to choose a wedding gift, he answered without hesitation that "he should prize a Wagner full score more than anything..." ${ }^{42}$, and he included a whole list in the order of preference, starting with Tristan und Isolde and ending with Die Meistersinger von Nürnberg. Also the choice of Berlin as the place to continue his studies (in 1897 Vaughan Williams studied composition for several months with Max Bruch) was determined, as the composer himself recalls, by the fact that Berlin was at that time the only city where Der Ring des Nibelungen was performed without cuts. ${ }^{43}$ Notably, Szymanowski also eagerly visited Berlin at the same age (though he did not take up studies there) and shared Vaughan Williams's fascination with Wagner, even though his modernist passions made him naturally prefer the music of Strauss, Reger and Schönberg.

Berlin offered the 25-year-old Vaughan Williams a great wealth of experiences and allowed him fully to absorb all aspects of the German culture which he had valued so highly at that time. However, his correspondence from February 1898 shows that his musical tastes were already beginning to change. He wrote critically of the works by contemporary German composers which he heard in Berlin, concluding that most likely the future of music lay "between Russia and England." First, however, he claimed that the Russians needed to stop being overly original and that the English should stop imitating others. In the same letter he remarks: "I very much believe in the folk tune theory" ${ }^{44}$, explaining that he means creative stylisation rather than direct quotations that bury original samples of folklore under a heavy mass of symphonic texture quite foreign to folk music. Interestingly, the concept of a peculiar cultural 'alliance' reaching

42 Quoted after: Hugh Cobbe, "Vaughan Williams, Germany, and the German tradition: a view from the letters", in: Frogley (ed.), Vaughan Williams Studies, p. 83.

43 In 1897, several months after Brahms's death, Vaughan Williams published an article which was an attempt to reconcile the followers of the two musical idols of that time Brahms and Wagner - through a historical argument which aimed to prove that the two masters in fact represent separate disciplines of art and are therefore incomparable. The article presents Wagner's work as the ultimate product of the historical development of the Romantic school. From Schubert and Weber to Schumann and further on, it was the rise of a new 'musical-dramatic' art that can no longer be referred to as 'music'. Wagner brought this historical process to full fruition by bringing the new art to its proper home - to the theatre. Brahms, at the same time, remained faithful to the traditional art of music. Cf. Cobbe, "Vaughan Williams, Germany", p. 83.

44 From a letter to Randolph Wedgwood, February 1898, quoted after: Cobbe, "Vaughan Williams, Germany", p. 87. 
over but omitting Germany anticipated Szymanowski's later ideas - though, as we know, Szymanowski did not see any role in his scheme for England. Most importantly, Vaughan Williams saw folk song already at that time as a kind of remedy that would make possible the liberation of music from German domination. As he recalled years later, folk song encapsulates the simplest type of musical idiom "which we unconsciously were cultivating in ourselves."

Indeed, the works he wrote after 1902 demonstrate his growing interest in modal and pentatonic scales, which frequently (as in three Norfolk Rhapsodies for orchestra) determine his basic harmonic structures and polyphonic progressions. At the same time, his thematic material and textures undergo a substantial reduction. From 1903 Vaughan Williams took up systematic field trips with Gustav Holst, thus becoming one of the pioneers of the movement for the preservation of England's disappearing original folklore. The following year Vaughan Williams joined the Folk Song Society and began to demonstrate a growing interest in 16th-century Anglican music, which - as he frequently stressed - is one of the foundations of English national culture. It would be an over-interpretation, however, as Michael Kennedy observes ${ }^{45}$, to suggest that the composer was 'liberated' from under German domination by direct contact with folk song. Quoting Vaughan Williams's own statement of 1903 that English folk song would not become the foundation of the English school of composition, Kennedy observes that the composer's busy work as an ethnographer was related more to his preoccupation with teaching music than to his interests as a composer. He wished to restore to the English society its forgotten and vanishing folk music, and even have it arranged so that it can enter concert repertoires ${ }^{46}$. According to Kennedy, what really 'liberated' and formed Vaughan Williams's mature, fully recognisable style was his stay in Paris and his studies with Ravel, which had commenced in January 1908. Ursula Vaughan Williams wrote ${ }^{47}$ that the composer was openly enthusiastic about his French master. "I am getting a lot out of Ravel - I hope it doesn't worry him too much - only I feel that 10 years

45 Michael Kennedy, Preface to the 2nd edition of National Music and Other Essays, (Oxford: Oxford University Press 1987), p. VII.

46 On the other hand, Vaughan Williams was aware already then - as evident from his later statements -- of the major social importance of the awareness of one's own native folklore for overcoming widespread conviction of the English people's unmusical nature. Changes in social awareness were of crucial importance to the growth of England's own school of composition.

47 Ursula Vaughan Williams, A Biography of Ralph Vaughan Williams, (Oxford: OUP, 1992), p. 80. 
would not teach me all I want" - he wrote in a letter, admitting that it was Ravel who suggested that he should orchestrate his pieces thinking in terms of sound colour, and not of instrumental lines ${ }^{48}$. Indeed, in 1909-1910 he wrote his first major works - On Wenlock Edge for tenor, string quartet and piano (1909) as well as the famous Fantasia on a Theme by Thomas Tallis for strings $(1910)^{49}$.

Notably, the key stylistic breakthroughs in Szymanowski's life followed a similar pattern. He also began to free himself from under the influence of German musical culture around the thirtieth year of his life (this change can be heard in his Tanz [Dance] and Der verliebte Ostwind [The East Wind in Love] from the cycle of Des Hafis Liebeslieder [The Love Songs of Hafiz]), while the principal breakthrough in his musical style came 8 to 10 years later. Both composers were in some ways captivated by the exotic, which led their imagination far from the canons of the dominant German culture. Szymanowski, like other modernists, drew on the culture of the Near East, while Vaughan Williams - on the 'native exoticism' whose charm Szymanowski would only discover after 1919. What both composers had in common was their fascination with French culture, which played a major role in the shaping of their respective styles - especially with the achievements of Maurice Ravel.

As observed above, ruralist nationalism (popular among the English intellectuals in the early 20th century) substantially influenced the development of Vaughan Williams's folkloristic passions. However, his article bearing the provocative title Who wants the English Composer $?^{50}$ published in 1912, proves that he did not embrace this ideology in an unreflective manner. In the article, he criticised his compatriots for writing derivative music, and observed that whenever any novelty reached the British Isles from overseas, the British invariably demonstrated a deplorable attitude that he characterised as "the desire to do it too." For art to be valuable, he claimed, it needs to grow organically out of the very life of the artist, the community he lives in, and the nation he belongs to. "Have not we all about us," he asked, "forms of musical expression which we can take and purify and raise to the level of great art?" ${ }^{51}$ Here he quoted examples: "the lilt of the chorus at a music-hall joining in a popular song, the children dancing to a

48 U. Vaughan Williams, A Biography, pp. 80-81.

49 This beautiful, nostalgically inspired piece was in fact composed for three string ensembles treated 'polychorally', and took advantage of the acoustics of Gloucester Cathedral.

50 RCM Magazine, Vol. IX, No. 1, 1912, quoted after: D. Manning (ed.), Vaughan Williams on Music, (Oxford: OUP, 2008), p. 41.

51 Quoted after Manning (ed.), Vaughan Williams on Music., p. 41. 
barrel organ, the rousing fervour of a Salvation Army hymn, St. Paul's and a great choir singing in one of its festivals, the Welshmen striking up one of their own hymns whenever they win a goal at the international football match, the cries of the street pedlars, the factory girls singing their sentimental songs? Have all this nothing to say to us?"52 he asked rhetorically.

The opportunities for artistic explorations of the folklore of great cities, which Vaughan Williams outlined above, seem to anticipate trends characteristic of the interwar period. His probable sources of inspiration are here (as Byron Adams claims) the poetry and views of Walt Whitman ${ }^{53}$ as well as the artistic tendencies he observed during his stay in Paris. As we know, the composer put these ideas in practice in his monumental London Symphony (1914), whose thematic material was inspired by the folklore of the London agglomeration. In Szymanowski's music we will not find similar fascinations, and most likely he would not have accepted Vaughan Williams's criticism of adopting novelties from abroad (except when it led to clearly derivative imitation). However, Szymanowski definitely embraced the idea of nobilitating elementary forms of musical expression and elevating them to the status of 'high art' - albeit in a different context.

The article discussed above is significant in the context of the formation of Vaughan Williams's views on the national and universal dimensions of music. The final impulse came from the traumatic experience of World War I. On a wave of patriotic fervour, the composer (like his friend Gustav Holst, and like Maurice Ravel on the other side of the English Channel) joined the army as a volunteer. The wartime experience deepened his sense of the power of human community, which became a nearly mystical value for him, but also gave a new dimension to his search for universal values, both in the spiritual and political spheres. Henceforth he defined himself as a federalist, a believer in a joint international European government - which did not collide in any way with his cultural nationalism. Later, during World War II, Vaughan Williams would write:

52 Manning (ed.) Vaughan Williams on Music., p. 41.

53 Whitman was one of Vaughan Williams's favourite poets. The latter was fascinated with Whitman's glorification of the powerful rights of life and nature, his search for the transcendental in seemingly banal everyday situations (including observation of the streets of Manhattan), and Whitman's ability to elevate the national element to a universal level. It is very likely that Vaughan Williams's cultural nationalism was largely shaped by his contacts with the poetry of Whitman. Cf.: Byron Adams, "Scripture, Church and culture: biblical texts in the works of Ralph Vaughan Williams", in: Frogley, (ed.) Vaughan Williams Studies, pp. 104-105. 
"I believe that the love of one's country, one's language, one's customs, one's religion, are essential to our spiritual health. (...) I believe that all that is of value in our spiritual life springs from our soil; but this life cannot develop and fructify except in an atmosphere of friendship and sympathy with other nations." ${ }^{.54}$

As evident from the above, for Vaughan Williams the notion of the community was the key to understanding national music. Both his historiosophic concept formulated in National Music, which determined his understanding of the laws of musical history, and the definition of the art of music itself - derived from that concept. Vaughan Williams starts his reasoning with a polemic on Whistler's view that the concept of national music is a curiosity that could be compared to 'national chemistry'. According to the composer, Whistler fails to recognise the difference between science and art. Science is a pure quest after knowledge and, as such, clearly has no limits. Art, on the other hand, and particularly musical art - uses knowledge merely as a means to an end - as Vaughan Williams puts it, as a tool to express personal experience in such a way that it becomes more understandable to others. The logical consequence of such reasoning is that those 'others' are - first and foremost - those closest to the author with respect to nationality and culture; as a matter of fact, they are members of the same nation or of another homogenous community of a similar kind. ${ }^{55}$

The above is a necessity, since no one can work in a social vacuum and the creative process always presupposes the existence of some kind of audience. The artist puts inspiration in a form shaped by the circumstances of his or her time and place, even though in most cases this process takes place spontaneously and without conscious effort. Therefore each artistic endeavour, regardless of the class of the artist's talent, is determined by the qualities of the community in which he or she has grown up ${ }^{56}$. Be it a Beethoven symphony or a folk musician's song, it is always shaped by history and by long tradition. As for folk songs, claims Vaughan Williams, we can say the same that Gilbert Murray said about the Bible and the works of Homer. They are not the work of one poet's imagination, but encapsulate the accumulated emotions of several generations; "there is in them,

54 R. Vaughan Williams, National Music, p. 154.

55 R. Vaughan Williams, National Music, p. 1.

56 This thesis can be corroborated by statements that come from Polish émigré composers - found e.g. in the memories of Alexandre Tansman, who claimed that childhood and adolescence, the cultural traditions the social environment in which one grew up, can never be erased from one's mind. Konstanty Regamey spoke in similar terms when he confirmed his allegiance to Polish culture. Cf.: Zofia Helman, "Emigrees by Choice", in: Musicology Today, Vol. 8, 2011, p. 12. 
as it were, the spiritual life-blood of a people..." 57 The same is true about music of the highest artistic calibre. True style - here Vaughan Williams quotes Hubert Parry - is not an individual product. The greatest geniuses are preceded by entire generations of nameless craftsmen-composers who are rooted in the tradition and who themselves have a long genealogy. Contrary to popular belief, great masters usually closed historical epochs, which were inaugurated by pioneers of lesser stature. "Is not the mighty river of Wagner," asks Vaughan Williams rhetorically, "but a confluence of the smaller streams, Weber, Marschner, and Liszt?" In his view, genius is "the right man in the right place at the right time" ${ }^{\text {" }}$. We know many examples of time that grew ripe, but the space remained empty for the lack of the right person that could fill it. On the other hand, "we shall never know of the number of 'mute and inglorious [John] Miltons' who failed because the place and time" were not ready for them. "Was not Purcell a genius born before his time?" asks Vaughan Williams; "was not [Arthur] Sullivan a jewel in the wrong setting?" 59

These assumptions have subsequently become the basis for reflections concerning various aspects of music history in the context of national ideology, and confirming the theses discussed above. The text is clearly influenced by interpretations of historical mechanisms borrowed from the theory of evolution, with echoes of the historiosophic concepts of Hegel and Herder. In this context, Vaughan Williams dedicates much space to 16th-century English religious music. He engages in a polemic with the opinions of British historians, who expressed their astonishment at the suddenness with which the English Renaissance had taken hold. Vaughan Williams presented his own scenario of historical events one that he believed in deeply. Throughout the Middle Ages, he claimed, English folk religious music flourished, though it was ignored by the English court (dominated by French culture) and by the Italianate church. It was from that music, from the oral tradition of folklore, that the energy, vitality and wealth of music during the Tudor era derived. Vaughan Williams quoted the evidence of the existence of French folk religious chant at the time of Charlemagne and drew a map of evolutionary development from folk song to chorale to organum to the polyphony of Thomas Tallis. He used a similar line of reasoning in his survey of European national schools, which (for obvious reasons) were at the centre of his attention. In this context he highly praised Chopin and Mussorgsky, whose

57 R. Vaughan Williams, National Music, pp. 23-24.

58 R. Vaughan Williams, National Music, p. 4.

59 R. Vaughan Williams, National Music, p. 4. 
originality, he claimed, was directly related to their creative approach to their respective folk and national traditions.

The local roots of great (naturally - German) masters are discussed separately in Vaughan Williams's book. He especially focuses on the "greatest of the greats" - J.S. Bach. Probably no art is more universal than the music of Bach, he claims, and still one could hardly find anyone more 'local' and more dedicated to his community. Bach never left his home country and seldom travelled outside his place of residence. He was steeped in local tradition. Vaughan Williams admits that Bach eagerly absorbed the achievements of other musical cultures, thus enriching his own style and technique. All the same, his artistic identity was decisively shaped by two traditions: the organ music of his 'Teutonic predecessors' and the religious songs that gave his own nation its identity. In this context, we read in National Music:

"Who has heard nowadays of the cosmopolitan hero Marchand, except as being the man who ran away from the Court of Dresden to avoid comparison with the local organist Bach?"60

Here we come to a key question: How did Vaughan Williams explain the supranational, universal impact of the works of great masters? In the first chapter of his book ("Why Music Should be National?") he questions the claim that music is a "universal language" and, with his characteristic humour, attributes this notion to "some misguided thinker, probably first cousin to the man who invented the unfortunate phrase 'a good European'" 61 . Even though most of the texts in National Music were written in the 1930s and breathe the atmosphere of that time, and notwithstanding the author's tendency to provoke by consciously exaggerating - his text does contain some clues that can serve as an answer to the question above. It seems that the key to his understanding of the phenomenon of musical universality lies in his descriptive, genuinely naturalistic metaphors, especially in the above-quoted metaphorical vision of Wagner's oeuvre as a great river fed by the waters of countless tributaries. Only music of the highest calibre can reach that universal level and transcend the boundaries of local community cultures. This is because a genius can express in both synthetic and original ways what the previous generations had laid the groundwork for. Universal literary masterpieces also come into being in this manner, Vaughan Williams claims. This concerns the already quoted examples of the Bible and of Homer. As a river needs those numerous tributaries, art also needs a rich multi-generational

60 R. Vaughan Williams, National Music, pp. 2-3.

61 R. Vaughan Williams, National Music, p. 1. 
tradition plus the right person at the right time and place, who will be able to collect all those influences into one powerful current capable of transcending national boundaries. The richer the tradition, the more music a given culture produces, and the greater the chance for great individuals to appear. Only such individualities can make a universal impact. ${ }^{62}$ It is evident from this line of argument that Vaughan Williams - unlike many of his contemporaries, including Szymanowski - did not believe in the existence of musically gifted and musically mediocre nations. Germany gave the world those he considered to be the greatest composers because through the conscious effort and perseverance of many generations, they built up a tradition that propelled and released tremendous creative force. England, on the other hand, oblivious of its own traditions plunged into the vicious circle of self-depreciation, convinced of its musical impotence. From this point of view, 'musical language' understood as a complex of technical-musical qualities is of secondary importance. In any given historical period, the dominant musical culture imposes its own language on the international society. As in the case of the Italian opera and the German symphony, this language becomes universal after some time.

Another universal aspect of art clearly pointed out by Vaughan Williams is of a philosophical nature: it is music's mission. The visible, audible and comprehensible media used by musicians are symbols not merely of other visible and audible phenomena, but of what transcends our senses and knowledge. ${ }^{63}$ Art is an attempt to reach the infinite, claims the composer. In his post-Romantic vision, a special place is reserved for music, which is rooted in everyday life in a way quite inaccessible to other arts. It is hard to determine whether Vaughan Williams knew the writings of Friedrich Schleiermacher and Ludwig Tieck, and to what extent he agreed with the Romantic metaphysics of $\operatorname{art}^{64}$. Still, it is this

62 The above discussed article of 1912 suggests that the key to the universal impact of music is the artistic class represented by the given artist. Those greatest and best known (universally acclaimed) have been closely connected with their respective national cultures. Cf.: U. Vaughan Williams, The Biography, p. 101.

63 R. Vaughan Williams, National Music, p. 122.

64 Frierdrich Schleiermacher (1768-1834), a German philosopher and theologist, was one of the most influential figures in the intellectual life of early German Romanticism. He is known as one of the precursors of modern hermeneutics as well as an advocate of the concept of parallelism between religion and the arts (especially music) as both lead human souls "to the infinite". The Romantic metaphysics of absolute, autonomous music conceived as an expression of the "infinite" was also represented in works of some eminent German writers of the same generation: Ludwig Tieck and Wilhelm Heinrich Wackenroder. Cf: Carl Dahlhaus, "The Esthetics of Feeling and Metaphysics”, 
aspect of his aesthetic thought that inevitably leads to questions concerning his worldview. Paradoxically, despite his many works inspired by religious texts or for use in the Anglican Church, Vaughan Williams was an atheist. In his mature years he moved toward a less radical kind of agnosticism, with some pantheistic strains.

Conflicts of outlook related to the clash of scientific rationalism and traditional religious faith were in fact frequent in Victorian England and had manifested themselves earlier in the Williams family. The composer's father who died when Vaughan Williams was just two years old - was an Anglican priest. The composer's mother - Charles Darwin's niece - attempted to reconcile belief in the revealed truths of the Bible with the results of scientific research. ${ }^{65}$ However, Vaughan Williams's worldview was affected most strongly not by his family connections, but by his historical studies in Cambridge (1892-95), where he came under the influence of such intellectuals as George Edward Moore and Bertrand Russell. As we know, Russell called himself an agnostic because he found himself unable to disprove the existence of God. He added, however, that it would be equally hard to demonstrate the non-existence of Zeus, Hera and other deities of ancient Greece. Presenting Christian dogma on one level with Greek mythology was - as we have seen - also characteristic of Vaughan Williams. For all we know, however, the composer did not share Russell's radical views on the institution of the Church. For him, the Anglican Church was an inherent part of the national tradition; it guarded moral and social order, and as such it was worthy of respect and support, regardless of one's personal attitude to the dogma itself. He was aware that culture grew out of the soil of specific religious ideas, which entailed a similar attitude to other religions and denominations as well. Apparently the scientific fascinations of his friends associated with philosophical realism did not quite satisfy the composer's mind. He felt the need for a spiritual dimension on which to build his own aesthetic, and which could constitute an alternative to traditional piety. As in the case of Szymanowski, it seems, for Vaughan Williams music became an alternative to religious faith.

in: Dahlhaus, The Idea of Absolute Music, (Chicago and London: University of Chicago Press, 1989), pp. 64-66.

65 Byron Adams quotes Vaughan Williams recalling a conversation with his mother, in which he asked her what she thought about her famous uncle's then highly controversial book. Her answer was evasive: "The Bible says that God made the world in six days, Great Uncle Charles thinks it took longer: but we need not worry about it, for it is equally wonderful either way." Adams, "Scripture, Church and culture", p. 101. 
The composer's views on the national and universal aspects of music as presented in National Music derived from his conviction about the indispensable 'rooting' of all cultural phenomena in their geographic and ethnic context. This conviction, supported by his experience as an ethnographer, influenced his interpretation of historical processes and gave his statements a specific colouring, frequent in the history of English thought. Apart from the strong influence of the theory of evolution, a distinct predilection for realism and pragmatism is evident here - both dear to the English philosophical tradition. Szymanowski would most likely have accepted many of the English composer's views without reservations, while others would have inevitably met with his opposition. Interestingly, he was the closest to Vaughan Williams when external historical events made him leave his "ivory tower" and firmly stand on the ground - which he not always seemed to have been eager to do.

Though Szymanowski did not present his views in a coherent and systematic way as Vaughan Williams had, the former's sketches, materials for Ephebos and his publications from the interwar period make it possible to compare the similarities and differences between the two composers with regard to the topic in question. As previously stated, for Vaughan Williams the point of departure was his pragmatic distinction between the aims of science and art. Szymanowski did not consider this issue, but in his sketches for Ephebos we find an interesting definition of music, put in the mouth of one of his novel's protagonists. His definition is based on the view of music as an autonomous art; it is strict and technical, but does leave some space for the audience. "The artist shall not go beyond certain territories because the audience would not be able to react emotionally to his work; the audience, on the other hand, shall make sure that those territories are as extensive as possible." ${ }^{\prime 6}$ Evidently for both artists the audience's emotional reaction was a constitutive element in the functioning of a work of art. For Vaughan Williams, however, the audience was primarily the ethnic community, whereas Szymanowski seems to be referring to a supra-national community based on the values of high culture. In the preface to Ephebos, Szymanowski declared himself wholeheartedly a supporter of 'pan-Europaism' in music, a trend of clearly elitist nature, which claimed that the most valuable individuals were to unite around "the greatest achievements of individual, spiritual culture." It purported to be "a secret plot of the solitary ones, faithfully guarding our most sacrosanct common good." ${ }^{67}$ Szymanowski opposed the thus understood pan-Europaism,

66 Teresa Chylińska (ed.) Karol Szymanowski, Pisma literackie [Karol Szymanowski, Literary Writings], (Kraków: PWM, 1989), pp. 136-137.

67 Chylińska (ed.) Karol Szymanowski, pp. 128-129. 
and destructive Bolshevik internationalism of the masses, and to nationalism (described as "narrow and egoistic in a way)." The Polish composer admits, however, that in the historical circumstances of his time his pan-European ideals had very little chance to be put in practice. He calls them "a chimera" and therefore sides with nationalism "as the only truly creative element in history." ${ }^{68}$ As Zofia Helman aptly $\operatorname{argued}^{69}$, Szymanowski found his spiritual homeland in the culture of the fin de siècle. In the extremely unfavourable conditions related to the historical cataclysms of the 1910s, it comes as no surprise that he should seek refuge in this 'homeland' while writing his novel. Sober realism, however, made him revise many of his earlier views. This is evident, for instance, in his letter to Zdzisław Jachimecki in 1920, in which he frankly admitted that "Poland has no time and no use for such artistic luxuries as me" and then adds with disarming pragmatism: "an honest policeman in the street, when viewed from this perspective, is worth more than I am." ${ }^{30}$ It was most likely this sober realism and the need to be useful in the face of political events that led Szymanowski to embrace the nationalist outlook. This only happened gradually, however, and not without certain reservations. "There are certain evolutionary phases (both in the history of humankind and of individuals) in which the national sentiment already loses its creative force and almost becomes an obstacle to the further journey", ${ }^{71}$ we read in his preface to Ephebos. From sketches written in the same period we learn that as late as the early 1920s, Szymanowski had formulated views with which Vaughan Williams could fully have agreed. In his comments on the historical roots of patriotism, he refers to it as "an offshoot of the primeval instinct of defending the family cave, later - the clan and tribe", which is strikingly similar to what Vaughan Williams had written concerning the origins of nationalism. Their conclusions were identical. According to Szymanowski, patriotism "in historical practice proved to be the most stable emotional support for any form of culture building - or perhaps the only one."72 Vaughan Williams would surely have also agreed with his Polish contemporary's realistic acceptance of the inevitability of national 'rooting':

68 Chylińska (ed.) Karol Szymanowski, Pisma literackie p. 129.

69 Zofia Helman, "Karol Szymanowski’s Songs in the Literary and Musical Context of His Times". In: The Songs of Karol Szymanowski and His Contemporaries, ed. Zofia Helman, Teresa Chylińska and Alistair Wightman, Los Angeles: Polish Music Center at University of Southern California, 2002, p. 6.

70 Chylińska (ed.) Karol Szymanowski, Pisma literackie p. 29.

71 Chylińska (ed.) Karol Szymanowski, Pisma literackie p. 129.

72 Chylińska (ed.) Karol Szymanowski, Pisma literackie. p. 193. 
"Even if we were to reject the emotional and idealistic content of such notions as 'patriotism, 'Fatherland' and our duty toward it [...] there will always remain a number of positive conditions which make it impossible to proceed in human history beyond the magic bounds of 'nationalism'. The idea of a 'human' is a philosophical chimera that has no existing counterparts on Earth, while the Poles, French, Chinese, Zulus, and the Russians most certainly exist as countless individuals whose spiritual and physical character has been determined once and for all by a number of undoubtable, indisputable facts such as the longitude and latitude of their place of living, the soil and climate, the shape of the landscape, the type of work..."73

The consequences of such a claim are obvious: the ethnic features are "by their very nature" reflected in the work of art. A question emerges, however: "should these features decide the value of the work?" Szymanowski answers in the negative:

The true value of a great work of art lies where the ethnic man - a Frenchman, Englishman or Pole - ends in an artist, and a human begins, facing life all alone as a metaphysical question. ${ }^{74}$

What we have, then, is man facing universal questions. This conclusion, echoing Witkacy (S.I. Witkiewicz) is, in some ways contrary to appearances, not far removed from musical universalism as defined by Vaughan Williams, especially with reference to Whitman's 'metaphysics of life', which (as I have mentioned earlier) greatly fascinated the English composer. Szymanowski's cult of individualism, identical with his postulate of respecting artistic freedom, which he emphasised till the very end of his life - led him to a warning which is sometimes misinterpreted as criticism of national art. In a sketch written most likely before 1920, we find the following remark:

National art as a postulate is a dangerous misconception. It is a notion born in quite a different cultural sphere; a purely rationalist conviction that the contemporary nation-state, should - among many other attributes $[\ldots]$ also have its own aesthetic. ${ }^{75}$

Further in his text, however, Szymanowski says this view is "quite correct" as long as it does not infringe "the absolute creative freedom of the artist", ${ }^{76}$ which would automatically annihilate the very possibility of a national art. This opinion does not contradict in any way his later declarations concerning national music or his own music, for that matter. The above may sound overly categorical; all

73 Chylińska (ed.), Karol Szymanowski, Pisma literackie, p. 208.

74 Chylińska (ed.), Karol Szymanowski, Pisma literackie, p. 209.

75 Chylińska (ed.), Karol Szymanowski, Pisma literackie, p. 209.

76 Chylińska (ed.), Karol Szymanowski, Pisma literackie, p. 209. 
the same, history confirmed the truth of this statement. The postulate of national art, when employed by official state politics (especially in a totalitarian state) does usually prove to be a "dangerous misconception". Szymanowski's pronounced stress on freedom as a necessary condition for the flourishing of art (including national art) finds its distinct parallel in Vaughan Williams's claim that the national character of music ought to develop and find expression in spontaneous individual creations, in fact - without the artist's conscious effort in this direction. Otherwise art will lose its most precious attribute - the sincerity of expression. Naturally, Vaughan Williams worked in quite different geopolitical circumstances and did not experience the same kind of threats as a composer who personally witnessed the Bolshevik system - one of the forms of the totalitarian state.

In his publications from the interwar period, Szymanowski presented his views using the (then popular) rhetoric based on the belief in the unique and historically unchanging features (both physical and spiritual) of different human races. In 1922 he commented that music "is so strongly related to an artist's individual qualities that it must eventually have roots in his racial background." 77 He claims one should look for the essence of national music not so much in the stylisations of folklore as in the ability to get an in-depth insight into the qualities of a given race. In the context of the forms of projecting and absorbing emotional content specific to a given nation, Szymanowski again refers to the idea of an 'emotional bond' so typical of his thought. The previously unspecified 'audience' takes on a distinctly national character, and so the 'emotional bond' becomes identical with Vaughan Williams' concept of 'sympathy', while the 'insight into racial character' finds its counterpart in the centuries-long tradition that gave birth to the cultural qualities specific to the given 'community'.

As we know, Szymanowski conceived of genuine national music as an organic and spontaneous combination of modern, top-class technical-formal solutions with expressive-emotional content that penetrated into the deepest layers of the nation's "racial identity"78 Only this kind of synthesis, he claimed, can guarantee

77 Michałowski (ed.), Karol Szymanowski, p. 60.

78 Szymanowski's critical attitude to the 19th-century tendency to identify national character in music with folk arrangements has already been anticipated at the turn of the 19th century in statements by, among others, Zygmunt Noskowski, and particularly by Aleksander Poliński, who emphasised that the expression on "nationality in music" depends on convergence between the "internal mood" of the musical work and the "general mood of the folk's music." Cf. Magdalena Dziadek, Polska krytyka muzyczna w latach 1890- 1914. Koncepcje i zagadnienia [Polish Music Criticism in 
that the national music will secure its place in the universal dimension as well. His model in this area was Chopin, whom he called "the creative genius of our race." Characteristically, it is in the context of Chopin's music that Szymanowski uses much of his 'racial' terminology. ${ }^{79}$ In 1920 he described how Chopin portrayed the soul of the people in its "infinite racial depth"80, while 10 years later he praised the composers of the Russian school for understanding Chopin's "original racial qualities." ${ }^{\text {"I }}$ In his 1921 publication dedicated to Stravinsky he stressed that "like our Chopin in the past", Stravinsky managed to capture "the racial features inherited from many generations" 82 , and in his article on Bartok's folklorism he criticised Bartok's placement of two great Romantics, Liszt and Chopin, "on one level in relation to the music of their respective folk", though he admitted that the "racial subtleties" of Chopin's art may not be quite comprehensible to foreigners, but can be much more easily grasped by the Polish audience ${ }^{83}$.

1890- 1914. Concepts and Ideas], (Katowice: Wydawnictwo Uniwersytetu Śląskiego, 2002), pp. 467-468.

79 As Zofia Helman aptly demonstrates, Szymanowski most likely understood the concept of 'race' in agreement with the 19th-century theory of Hippolyte Taine, as "a complex of permanent mental features, of predispositions and original qualities" which reach deeper than "the national character". Cf. Z. Helman, "Dylemat muzyki polskiej XX wieku - styl narodowy czy wartości uniwersalne?”, [The Dilemma of Polish 20th-Century Music: A National Style or Universal Values?] in: Ana Czekanowska (ed.) Dziedzictwo europejskie a polska kultura muzyczna $w$ dobie przemian [European Heritage and Polish Music Culture in the Age of Transformations], (Kraków: Musica Iagellonica, 2005), p. 181.

80 Michałowski (ed.), Karol Szymanowski, p. 40.

81 Michałowski (ed.), Karol Szymanowski, p. 41. Another author who wrote quite extensively about the "racial kinship" of the Slavic peoples and its musical consequences was Ludomir M. Rogowski, who believed in the Ur-Slavic rots of Polish culture. In the interwar period, his views seem to have been relatively the closest to Szymanowski's statements as quoted above. Cf.: Ewa Wójtowicz, „'Muzyka nie jest kosmopolityczna' - Ludomira Michała Rogowskiego myśli o muzyce narodowej ["Music is not cosmopolitan" - Ludomir Michał Rogowski on national music], in: Skowron (ed.), Karol Szymanowski w perspektywie..., pp. 79-92.

82 Michałowski (ed.), Karol Szymanowski, p. 54.

83 Michałowski (ed.), Karol Szymanowski, p. 173. Leszek Polony aptly observes that: "Szymanowski never explained in any detail what he understood by 'racial qualities' and the ways they are manifested in music. In his aesthetics, these qualities play the role of an intangible, indefinable factor akin to the 'absolute' of the Romantics." Cf. Leszek Polony, Polski ksztatt sporu o istote muzyki [The Dispute Concerning the Essence of Music in Poland], (Kraków: Akademia Muzyczna, 1991), p. 213. 
Vaughan Williams did not emphasise the need for the Europeanisation and constant modernisation of musical language (though he did introduce these elements in his own music from the interwar period). However, he would have agreed with Szymanowski's other conclusions, without reservation, concerning the essence of contemporary national music. Though he did not refer to the concept of 'race' in his writings, Vaughan Williams likewise believed in the presence of unchanging, historically constant expressive-emotional qualities which were the determinants of the national style (more profound than folk stylisations). The English composer was also equally convinced about the existence of subtle musical features that could only be understood within the given national culture.

We can find other analogies between the writings of the two composers as well. Like Vaughan Williams, Szymanowski granted Bach the highest place in the history of music: "I frequently feel that Bach is the very summit of music." ${ }^{4}$ Szymanowski also shared the belief in the metaphysical mission of art: "Most important in art is what lies beyond it, a certain transcendental element. Even unmusical people can feel the air of another world blowing through music." ${ }^{35}$ Szymanowski respected tradition and its culture-building power. He even used identical comparisons as Vaughan Williams when he stressed that the great masters are like aristocrats with huge family trees; whole generations contributed to their identity. Another striking similarity is their similar attitude to institutional religion. For both composers the religions they were brought up in were strongly related to national traditions; both saw religious faith as a source of the wealth of imagination and priceless artistic inspiration. Szymanowski's confession that the "Holy God [Polish religious hymn] sung in some village church" moved his "religious instinct" more deeply than the most sophisticated Latin mass - would have undoubtedly found full sympathy with his English colleague ${ }^{86}$. Another striking analogy is Szymanowski's treatment of the culture-building function of folk song, which he poetically describes as "the spring of vital inspiration eternally flowing from the very heart of the race." ${ }^{87}$ Both composers quote folk song as proof of the existence of a primeval, instinctive need for music among the wide masses. Finally, as mentioned above, both saw the domination of the German music tradition as a threat to 20th-century national schools in music. "Sound development of Polish music depends solely on how thoroughly we can liberate

84 Michałowski (ed.), Karol Szymanowski, Pisma muzyczne, p. 451.

85 Michałowski (ed.), Karol Szymanowski, Pisma muzyczne, p. 456.

86 Michałowski (ed.), Karol Szymanowski, Pisma muzyczne, p. 371.

87 Michałowski (ed.), Karol Szymanowski, Pisma muzyczne, p. 269. 
ourselves from the powerful grip (...) of German music", wrote Szymanowski in 1922. Five years later, he stood up in defence of other national schools as well:

Great music can be founded on something different from the German 'emotional type'. The racial qualities of other national groups must be elevated to the rank of the highest values in $\mathrm{music}^{88}$.

Despite all these analogies found in the writings of the two composers, they differ not only in the distinct intellectual traditions on which their reflections are based, but also in their attitude to modern trends of general European significance. Szymanowski would not have shared Vaughan Williams's distrust for the notion of a 'good European'. He frequently conveyed what amounted to genuine enthusiasm for pan-European values and expressed his conviction that the "separate racial identity of Polish music in its deepest sense" can only be achieved through Europeanisation. Isolation leading to parochialism, he believed, was the greatest threat to that true identity. Vaughan Williams explained that he did not advocate artistic provinciality, but in his writings he did not dedicate much space to that threat. After all, he spoke for a culture that had dominated a large part of the world and could hardly be seen as provincial. It also seems likely that Szymanowski's attachment to Europe and its values (which he strongly emphasised during his stay in the United States) resulted from his sense of integral relation with the continent - stronger than in the case of the English composer. 19th-century England, busy constructing its own empire, frequently distanced itself from the continent. The greatest discrepancy between the two composers' views concerned, however, not so much the 'strategy' but rather the 'tactics' of building a modern national school. Szymanowski resolutely rejected all 'protectionist' inclinations in the repertoire policies of concert organisers. $\mathrm{He}$ claimed that music institutions ought to be open to works of the highest artistic value regardless of the nationality of their authors, while compositions which are "dilettante and devoid of talent, however strongly rooted to our national tradition they might be" 89 ought to be left out of concert programmes. Szymanowski thus represented an attitude of a truly liberal openness combined with an optimistic appraisal of the vitality of the Polish nation and its culture:

"We are indeed a healthy and strong society, and no external influences can jeopardise our effort to build our own culture. On the contrary, we can easily absorb the genuinely valuable and sound elements of foreign culture, and this can only be to our benefit." ${ }^{\prime 0}$

88 Michałowski (ed.), Karol Szymanowski, Pisma muzyczne, p. 378.

89 Michałowski (ed.), Karol Szymanowski, p. 152.

90 Michałowski (ed.), Karol Szymanowski, p. 155. 
Vaughan Williams, on the other hand, liked to compare the revival of English music to the growth of a young and still fragile plant and therefore postulated creating ideal 'greenhouse' conditions for that growth, with a tendency to protect his own culture from external competition ${ }^{91}$. Some of his statements are highly controversial in this context; one of them was quoted by Alistair Wightman as an example of English "tweedy chauvinism", with which Szymanowski's very open attitude "contrasts pleasantly"92. Wightman's example shows that for the sake of prompting his nation to produce its own music, Vaughan Williams was ready to accept such extreme solutions as a ban on the performance of foreign music:

"In this way the people of each nation, being prevented from employing others to make music for them, would be obliged, if they wanted it, to make it for themselves...If there was no indigenous music to be had the art in that country would die out altogether...."93

This peculiar proposal had no chance to be put in practice. It seems unlikely that Vaughan Williams, known for his realism, could treat it seriously. On the other hand, the quotation reveals both strong the emotional involvement and presence of some historical trauma (related to the mass employment of foreigners by courtly patrons some centuries before, which limited the patronage of native musical art). Michael Kennedy warned readers against overly literal treatment of the composer's verbal extravaganzas and of his deliberately exaggerated statements, characteristically presented with tongue in cheek.

Kennedy represented Vaughan Williams as a man of impressive build whose opinions were just as big and bold as his looks ${ }^{94}$. His sense of historical mission frequently led him to make provocative statements. Concerning national music, Vaughan Williams appears to have represented a stance that was so 'protectionist' that even Szymanowski's staunchest opponents from Warsaw seem liberal in comparison. Still, life itself proved that the rhetoric illustrated above did not translate into action in the composer's own life. After the outbreak of

91 It transpires from the results of Levi's research that in early 20th-century Great Britain slogans like "buy British" were also frequently applied to music. Cf.: Eric Levi, "Those damn foreigners' Xenophobia and British Musical Life During the First Half of the Twentieth Century", in: Twentieth-Century Music and Politics, ed. P. Fairclough, (London and New York: Routledge, 2016), pp. 81-96.

92 "The attitude revealed here [i.e. in Szymanowski - author's note] contrasts pleasantly with the tweedy chauvinism of Vaughan Williams". In: Alistair Wightman, "Szymanowski's Writing on Music - A Comparative Study", Res facta No. 9, PWM 1982, p. 47.

93 Wightman, "Szymanowski's Writing on Music" p. 47.

94 Kennedy, Preface, p. V. 
World War II, circumstances favoured possible legal restrictions in the context of a threat to national values. As the Nazi repressions against Jews and political opponents escalated, the number of German emigrants to the UK was growing in the late 1930s. These included many musicians, musicologists, and music critics. Soon after the war broke out, the British authorities were forced to intern the refugees from Germany and Austria for reasons of prevention. Though Vaughan Williams expressed his fears of England being dominated by these emissaries of German musical culture, he did his best to free the interned musicians. He used his authority, social position and connections for this purpose. In the summer of 1940 he was appointed head of the British government's advisory committee for refugees, and obtained release for most of the detained artists.

What did he feel at that time? We can glean this from his letter (quoted by Hugh Cobbe) to Ferdinand Rauter (an Austrian musician who settled in London in the late 1930s), written on 16th August $1942^{95}$. In the letter, Vaughan Williams frankly expresses his fear that the recent "peaceful invasion" of England by Austria might completely annihilate what he called (using one of his favourite naturalistic metaphors) "the tender little flower of our English culture." Considering Austria's glorious musical tradition, he argued, it is only natural that they see it as one and only, and are prone to dismiss everything that differs from it as an error or a product of ignorance. The Austrians also consider it as their mission that they should instil their culture in every soil they settle on, as the only one worthy of being cultivated. However, as Vaughan Williams warns his reader, any attempt to convert England into Austria's musical protectorate "could kill all the musical initiative in this country - destroy all that is vital and substitute a mechanical imitation of your great art - which will have no vitality, no roots in the soil and no power to grow to full stature." ${ }^{96}$ The only viable solution is assimilation: "Become Englishmen - try to assimilate our artistic ideals and then strengthen and fertilize them from your own incomparable art." ${ }^{\prime 97}$ In the final section of the letter, he explains the reasons for the atrophy of musical creativity in his fellow countrymen, as diagnosed earlier in his National Music: "As you must already know from your sojourn in England that there is a tendency, clearly, among English people to take that 'Schmidt' is musical - while Smith is ipso facto unmusical." ${ }^{18}$ What follows is a request to support Smith and help him

95 Cobbe, "Vaughan Williams, Germany", pp. 95-96.

96 Quoted after: Cobbe, "Vaughan Williams, Germany”, p. 95.

97 Cobbe, "Vaughan Williams, Germany", p. 95.

98 Cobbe, "Vaughan Williams, Germany", p. 96. 
to gain self-confidence, to discover his artistic potential and possibilities, so as not to perpetuate the vicious circle of impossibility and the false conviction that Smith's only chance was "musically to turn into a Schmidt."

Though leftist and liberal ideologies sometimes treat nationalism and chauvinism as one and the same phenomenon, it would be unfair and far-fetched to label the author of the London Symphony as a chauvinist. He never claimed the superiority of his own nation and never exhibited contempt toward other nations - quite the opposite. One should probably agree with Frank Howes's description of Vaughan Williams's nationalism as a 'positive' one ${ }^{100}$, i.e. devoid of chauvinistic leanings and based on the conviction that the international community gains its most originality and distinct character thanks to the contributions of the various national cultures. It is also hard to imagine a chauvinist who enthusiastically supports the idea of a united Europe, as Vaughan Williams did. He believed that the community of nations ought to be integrated politically, but the different cultures and nations ought to preserve their separate identity which stems from their authentic native traditions. In this view, Europe is a multi-coloured mosaic of cultures developing bottom-to-top from grassroots and strongly rooted in local traditions. The idea of a universal, supra-national language thus became of secondary importance.

Szymanowski approached the cause of European musical culture rather differently. To him, most important were the top-to-bottom, shared system of values and the common musical language which, thanks to the contributions of the various 'racial identities', gained a national colouring. While Vaughan Williams emphasised the community and the ethnic-territorial identity, Szymanowski attached more significance to the intergenerational bond, which resulted in the need for the constant modernisation of style. The reason why Vaughan Williams was less critical of isolationist tendencies than Szymanowski may have been the different historical experience and the different causes of the crisis of musical culture in Poland and England. Polish culture was indeed seriously undermined by provinciality and parochialism, which served as a serious warning for Szymanowski, Karłowicz and the entire Young Poland generation. As for the crisis of English musical culture, Vaughan Williams believed its roots were quite the opposite - the decline of England's own original tradition, forgetting one's

99 Quoted after: Cobbe, "Vaughan Williams, Germany", pp. 95-96.

100 F. Howes, Ralph Vaughan Williams, Grove's Dictionary of Music and Musicians, London 1975, Vol. VII p. 700. Ernest Gellner describes this type of nationalism as 'universal. Cf. Gellner, Nations, p. 1. 
own folklore, which strengthened and popularised the conviction that a nation with no living folklore cannot be a musical one. In order to authenticate their opinions, Szymanowski quoted the case of Moniuszko while Vaughan Williams pointed out the phenomenon of the 'provincial composer' Mussorgsky as an example. The two nations' different historical experiences thus shaped the different ideologies of national music represented by the two composers.

What was the significance of Vaughan Williams's and Szymanowski's ideas and oeuvre for the later development of musical culture in their respective countries? How were they viewed by their major successors? Szymanowski, as we know, became the unquestioned leader of the Polish 20th-century school of composition. His music inspired the successive generations, from those that grew up in the 1930s to the "new Romanticism" of the 1970s and even contemporary Polish jazz. Szymanowski's thought on music, naturally cleansed of the anachronistic references to the category of 'race', does not provoke opposition today. His postulates of organically embedding the national component in the universal European musical language and of avoiding isolation - now seem obvious.

The fate of Vaughan Williams's artistic legacy was more complex. Already in the late 1930s he came under the criticism of the young generation of composers at that time. Both William Walton, the rising star of English music, and his debuting younger colleagues, of whom Benjamin Britten is the best known openly expressed their fascination with the outside world. They rejected the nationalist rhetoric; their idols were Stravinsky, Prokofiev, Bartok, Schönberg, Ravel, Gerswin, and even American jazz. More than in the native folk song, they were interested in new compositional techniques and in technical mastery. They attacked Vaughan Williams with arguments similar to those that Szymanowski and Karłowicz had once used against the Polish advocates of the inviolable (provincially conceived) national tradition. The British conservative press printed reviews that opposed the suspect cosmopolitan competence and technical brilliance to something vaguely defined as 'sincerity of expression', which was supposed to be a quality of native English music. The adherents of European modernism counterattacked by claiming that this 'sincerity' is a cover for common incompetence and amateurism. All this was tinged with political conflict. The young generation for the most part did not know Vaughan Williams's pro-socialist sympathies, which one could hardly have guessed, considering his social position. So he was attacked by persons with leftist views. The hardest times came for Vaughan Williams in the 1950s, when followers of the pro-European option gained a powerful ally in many of the German and Austrian émigrés for whom Vaughan Williams had so generously interceded. By now they had become influential critics, journalists, conductors and professors of British 
universities - and it was much more difficult for them to understand the music of Vaughan Williams than that of Britten, whose brilliant career many of them supported (one example is Hans Keller). From the 1950s onward, Vaughan Williams's position was becoming distinctly weaker, while that of Britten and Szymanowski was getting stronger. The latter was recognised, also in British musical circles, as one of the leading 20th-century composers - and his fame overshadowed that of Vaughan Williams in the latter's own country.

However, the "Guardian of British Music", as Ferdinand Rauter called him in a letter -eventually emerged victorious. Before the outbreak of World War II, Britten had left for the United States with the intention of settling there permanently. America welcomed him warmly and he scored major successes there; all the same, he decided to return. It was only in America that Britten recognised his own separate national identity and realised that his proper place was on the other side of the Atlantic. In his letters and memories from that time, he wrote about cultural 'rooting' and about the significance of tradition. How homesick he must have been we may surmise from the fact that he returned at the moment of greatest threat, when England was facing the entire Nazi German power alone. Despite his pacifist outlook and danger to his own life, he came back to his fatherland in the time of combat. His first operatic hero, Peter Grimes, with whom he had largely identified with himself, preferred to perish rather than leave the land where his heart was. "I am a native rooted here..." Some time later Britten admitted that he had always had the deepest respect for Vaughan Williams, however much they differed in their views on art.

This transformation, which took place when Britten was almost thirty, could be interpreted as a sign of maturity, but also - as the first triumph of the author of National Music. His second triumph was the awakening of the dormant musical potential in his nation, the fruit of hard work. Nowadays nobody can doubt any more that Smith is just as musical as Schmidt, and Great Britain ranks among the greatest musical powers of the present-day world. Since the late 1980s, Vaughan Williams's vast and partly forgotten output of compositions has undergone a distinct renaissance and attracted growing interest not only in the English-speaking countries, but worldwide. His great hope has also been fulfilled, and we have a united Europe without borders. Now there is a chance to build such international relations as the English composer dreamt of, based on integrity or on political cooperation which guarantees peace while maintaining cultural diversity - a "Europe of Homelands" which safeguards the continuation of national and regional traditions. There is also a chance - as Szymanowski wished - for Polish culture to win, once and for all, its permanent place on the map of Europe, so that it will never again play the role of a backwater cut off from the rest of the world. 



\section{The Racist Foundations of the National- Socialist Thought on Music ${ }^{101}$}

"The 'nation' is a political expedient of democracy and Liberalism. We have to get rid of this false conception and set in its place the conception of race, which has not yet been politically used up."

This statement by Hitler, reported by Hermann Rauschning ${ }^{102}$, refers to the vision of the future global 'revolution' which he presented to the elites of the Nazi movement. The revolution was to result in the emergence of a new social order based on biological and racial criteria. Nazi chauvinism was thus most likely only a passing stage for Hitler, a political necessity that would lead to racial 'internationalism' as the socio-political foundation of the new system. Though today it is obvious for us that this vision was sheer madness, one should recall its proper historical context. The concept of race - "not yet been politically used up," as Hitler claimed in his time, but today considered as compromised and downright dangerous - was quite common in the writings of the interwar period and in most cases free of the negative meanings that tragic history would later impose

101 This chapter is an extended version of an article entitled "Racism in Nazi Historiography and Concepts of Music Theory", printed in: Nationality vs Universality: Music Historiographies in Central and Eastern Europe, ed. Sławomira Zerańska-Kominek, (Cambridge: Cambridge Scholar Press, 2016), pp. 212-238.

102 Hermann Rausching, The Voice of Destruction, New York 1949, p. 232. In light of research conducted in recent decades by the Swiss historian Wolfgang Haenel (Die Fälschung von Rauschning Gespräche mit Hitler, Berlin: Ullstein, 1984), Rauschning's book has lost much of its credibility. On the other hand, what Haenel proves is that Rauschning could not have held nearly a hundred conversations with Hitler, which he claimed to have been hissource of information. For this reason, Haenel recommends as more trustworthy the book Hitler: Memoirs of a Confidant (Yale: University Press, 1985) by one Otto Wagener, a distinguished veteran of the Nazi movement, who had private contacts with Hitler. Paradoxically, however, Rauschning shows Hitler as what he really became later during the war, whereas while reading Wagener's memories we begin to suspect that he tried to whitewash his idol -following the old principle that the tsar is good, only surrounded by bad officials. Wagener presents the führer of the Third Reich as a gentle and sensitive man, in fact - an advocate of peace, whose main historical mission was to strengthen Christian morality in German society (!). In this context we may accept the view of German historian Martin Broszat, who argues that while the 'conversations' themselves are fiction in Rauschning's book, the information is correct and collected from other, mostly well-informed sources. 
on it. Too many men of science, art and politics the consideration of the cultural and physical features that distinguish one human race from another seemed to be something obvious, and racial prejudice, personal resentments as well as stereotypes were used in public statements without the fear of their authors being compromised. Claude Levi-Strauss defined racism as "a doctrine that claims to see the mental and moral characteristics of a group of individuals (however the group may be defined) as the necessary effect of a common genetic heritage."103 Thus, conceived racism was nothing embarrassing for a large part of Europe's elites in that period. For instance, Neville Henderson, the British ambassador to Berlin in 1937-1939, saw nothing inappropriate in his published remark that the frequent Prussian tendencies to cruelty and militarism might have resulted from the admixture of 'Slav blood'104. Henderson reacted with indignation to the antiJewish actions of the Nazis, but in his own views he betrayed a predilection for covert acceptance of anti-Semitism, albeit in a more 'civilised' form, as well as of dictatorship itself, which need not always be associated with tyranny:

"One cannot, just because he is a dictator, refuse to admit the great services which Signor Mussolini has rendered to Italy; nor would the world have failed to acclaim Hitler as a great German if he had known when and where to stop; even, for instance, after Munich and the Nuremberg decrees for the Jews." 105

We should remember that this statement comes from a seasoned diplomat's memoirs in which he strove to create the best possible impression of himself. Henderson was hardly isolated in his views. According to Leonard Mosley ${ }^{106}$, Lord Camrose, owner of the "Daily Telegraph" and one of Chamberlain's most powerful supporters as prime minister, won a suit against Oswald Mosley, leader of the British fascists, whom he had accused of insulting him by calling him a Jew in public. One of Chamberlain's cabinet members, Sir John Simon, felt it appropriate to make a public statement that despite his 'Biblical' name, he was of Welsh, and not of Jewish descent.

Antisemitism was omnipresent in Europe at that time, and was also present as we know - in Polish political writings of that period. The National Democrats, and especially the radical party wing, were at the forefront of this trend. The anti-Semitic sentiment of some activists was so strong that they made absurd

103 Claude Lévi-Strauss, The View from Afar, Preface, (Chicago: University of Chicago Press, 1992), p. XIV.

104 Neville Henderson, Failure of a Mission:Berlin 1937-1939, (New York: G. P. Putnam's Sons, 1940), p. 5.

105 Henderson, Failure of a Mission, p. 12.

106 Leonard Mosley, On Borrowed Time, (London: Pan Books Ltd, 1969), p. 120. 
accusations concerning a German-Jewish plot against Poland or (until the Nazi terror became apparent) - questioned the sincerity of Hitler's anti-Semitism ${ }^{107}$.

On the other hand, interest in racial issues is evident in statements made by eminent artists and humanists who could hardly be suspected of pro-Nazi sympathies, or in fact of subscribing to any specific political option. As we have mentioned before, Karol Szymanowski used the then fashionable term 'race' instead of the traditional 'nation'. His comments on the 'Jewish question'108 (which we will discuss later) can easily cause some embarrassment today. He cannot be unequivocally labelled as an anti-Semite, but he clearly copied certain stereotypes cherished by the German völkisch movement tradition, which also made their way into the racist writings on music created in the Third Reich.

In the context of the above examples (naturally, many more could be quoted), Hitler's statement quoted at the beginning of this chapter could hardly shock the public opinion - especially in Germany, where racist ideas, the Germanic version of Christianism, as well as völkisch mysticism had taken root for many generations, and where Nazi ideology found a fertile soil. Hitler was well known for his ability to sense the mood of the masses and the political climate. He would not have used racist ideology to propel his totalitarian state if it had not found favour with many millions of Germans. The examples of racist concepts as applied to the music theoretical debate, which we present in this study - therefore need not be viewed as the product of political conformism or of totalitarian control. Though the political element was undoubtedly highly significant, one can hardly overestimate the deep-rooted stereotypes and the peculiar fashion for racist ideas among intellectuals. It seems highly likely in this context that many of the music theoreticians we quote here truly believed in the racial doctrines, and that some of their concepts could have been formulated quite independently from the Nazi terror.

Racist music-theoretical concepts presented in the Third Reich stem from the same sources as the entire Nazi ideology. The oldest of them date back to 18th-century Volkist (völkisch) ideology ${ }^{109}$, which was an original German

107 Cf. Bogdan Halczak, “Cele polityki endeckiej wobec mniejszości żydowskiej w Polsce w latach 1919-1939" [Aims of National Democratic Policies toward the Jewish Minority in Poland, 1919-1939], Biuletyn Żydowskiego Instytutu Historycznego, Nos 3/95 - 2/96, pp. 37-47; "Stosunki polsko-niemieckie w publicystyce obozu narodowego w latach 1922-1939" [Polish-German Relations in the Publications of Polish Nationalists, 1922-1939], Przegląd Zachodni, No. 3, 1995, pp. 118-127.

108 Karol Szymanowski, "Kwestia Żydostwa" [The Jewish Question], [in:] Chylińska (ed.) Karol Szymanowski, Pisma literackie, pp. 225-240.

109 The meaning of this term is explained in detail in George L. Mosse, The Crisis of German Ideology: Intellectual Origins of the Third Reich, (New York: Grosset and Dunlap, 1964). 
literary-philosophical basis for many aspects of Nazi ideology. The central idea of the Volkism (Völkismus) was a mystical bond between the soul of the individual, the collective spirit of the nation, and the natural environment.

"According to many Volkist theorists, the nature of the soul of a Volk is determined by the native landscape. Thus the Jews, being a desert people, are viewed as shallow, arid, 'dry' people (...). They thus contrast markedly with the Germans, who, living in the dark, mist-shrouded forests, are deep, mysterious, and profound. Because they are so constantly shrouded in darkness, they strive toward the sun, and are truly Lichtmenschen."110

The most influential ideologist and promoter of Volkist ideology in the 2nd half of the 19th century was Paul de Lagarde, who postulated a Germanic religion based on a return to Christian roots. ${ }^{111}$ History, according to de Lagarde, was an expression of religious spirit, which manifested itself to individuals only within the boundaries of a national community. The basis for this relationship was a mystical union of cosmic energy, the natural environment and the nation, which integrated these three ideas into a mysterious organic whole. Anti-Semitism was a natural consequence of de Lagarde`s ideas, but it was motivated by religion, not by racism. Those Jews who denounce their religion - which de Lagarde saw as leading to materialism and a source of evil - can find their place in the national community. This type of anti-Semitism corresponded to the legal situation of the Jews in Germany and Austria before 1918, when they had no access to higher academic positions and to managerial posts in the state administration and the army unless they converted to Christianity. This was the probable reason behind Gustav Mahler's conversion to Catholicism before taking up the post of director of Vienna's Imperial-Royal Opera.

Julius Langbehn, the next influential continuator of the Volkist tradition, did not share his predecessor's religious motives. In his book Rembrandt als Erzieher $^{112}$ he expressed his racially motivated hostility toward the Jews, even postulating that they should be expelled from Germany. His views contrasted with those of Eugen Diederichs ${ }^{113}$, a representative of a modern and tolerant version of Volkism in the early 20th century - a Jena publisher and man of the world known for his eccentric manners and interests. Though he also saw the Jews as racially alien for the Germans, devoid of inner spirituality (because they are uprooted), he claimed that they played an important role by integrating the

110 Mosse, The Crisis, pp. 4-5, quoted after: Barbara Johnson, A World of Difference, (Baltimore: JHU Press, 1989), p. XVIII.

111 Cf. Paul de Lagarde, Deutsche Schriften, (Göttingen: Dieterich, 1878).

112 Leipzig: Hirschfeld, 1900.

113 Cf. Mosse, The Crisis, pp. 79-82. 
different European nations, tempering nationalisms and conflicts. His view, however, was rather an exception among the adherents of Volkism.

The second source of racism in Nazi ideology were the (pseudo-)scientific works of the main theoreticians of racism: Joseph Arthur de Gobineau ${ }^{114}$, a French diplomat and student of racial history and Houston Stewart Chamberlain, an English botanist and natural philosopher living in Germany, whose book Die Grundlagen des XIX Jahrhunderts ${ }^{115}$ influenced Hitlerism particularly strongly. Both of them argued for the racial superiority of the Germanic race and warned against degeneration supposedly caused by race mixing, which, they claimed, led to the decline of many ancient cultures.

Chamberlain, who married Richard Wagner's daughter and was close to the composer's family, evidently absorbed Wagner's pan-Germanic doctrines and, combining Gobineau's theories with social Darwinism, made a name for himself by claiming that the future belonged to the Germanic race. He also denied the historical causes of the hostility between the Germans and the Jews, and argued that the conflict was the result of diametrically different racial characteristics, which determined the course of history and were a hotbed for the inevitable racial struggle. It was this element of Chamberlain's theory that laid the foundations for Nazi historiosophy and played a key role in the Nazi interpretations of music history. Another of Chamberlain's extremely popular concepts frequently quoted in musicological publications under the Third Reich was the identification of the external physical features of the given race with its internal, spiritual qualities. Chamberlain was convinced that these two spheres mutually conditioned each other.

The third source - especially significant for Nazi music theory - was Wagner's famous pamphlet Das Judenthum in der Musik (Jewry in Music). This text was of special importance because of the Nazi cult of Wagner as a prophet of the Tausendjähriges Reich (Thousand-Year Reich). Both Wagner's music dramas and his writings had a major impact on Hitler's political concepts ${ }^{116}$. Though Wagner was motivated by personal circumstances rather than any kind of ideology, his immense authority was employed in the service of the promotion of racism soon after his death. This was mostly the work of Chamberlain, Cosima Wagner and

114 Cf. Joseph Arthur de Gobineau Esai sur l'inegalite des races humaines, (Paris: FirminDidot frères, 1853).

115 Houston Stewart Chamberlain, Die Grundlagen des XIX Jahrhunderts, (München: Bruckmann, 1900).

116 More on Wagner's posthumous influence on Hitler's thought, political concepts and aesthetic taste - in: Joachim Köhler, Wagner's Hitler - the Prophet and His Disciple, Engl. transl. Ronald Taylor, (Oxford: Polity, 2001). 
the Wagnerian Club, which they ran and which exerted major influence over the German elites in the early 20th century ${ }^{117}$. Additionally, Chamberlain's extensive monograph dedicated to the Bayreuth master's work and thought ${ }^{118}$ reinforced in the minds of Germany's interwar intelligentsia an image of Wagner that was well suited to Nazi ideologists. Chamberlain stressed that Wagner did not believe in the equality of races and warned people against the disastrous consequences of mixing them. He was said to have inherited these views from Count de Gobineau, who was allegedly his friend ${ }^{119}$. The British founder of modern racism also dedicated much space to his famous father-in-law's pamphlet on Jews and music, claiming that this was not the only text in which Wagner had warned his readers against the destructive influence of the Jews on the culture and moral integrity of European nations. Chamberlain's analysis of Wagner's pamphlet was accompanied by an extensive historical commentary, which reached far back into European history in order to demonstrate to German readers how many intellectuals of the past sensed the 'Jewish threat' and expressed the view that Jewish religion is based on egoism incompatible with the rules of Christian social life ${ }^{120}$.

As evident from this brief survey, the racist ideas presented by the Nazis were far from original. What was undoubtedly new was the melding of many heterogeneous, scattered, previously elitist concepts into one doctrine and turning it into a general-national and legal one - into a crucial tool of state control. Also of major importance in the context of Germany's preparations for the war was the psychological and political dimension of racism. As Erich Fromm wrote in 1941, "While Hitler and his bureaucracy enjoy the power over the German masses, these masses themselves are taught to enjoy power over other nations and to be driven by the passion for domination of the world." ${ }^{121}$ Racism in the Nazi version gave every 'racially pure' German - regardless of social position - a sense of superiority over the 'inferior races' and consequently legitimised exercising over those races an authority just as ruthless and brutal as the one that ruled the Germans themselves. ${ }^{122}$

117 Cf. Mosse, The Crisis, p. 125.

118 H. S. Chamberlain, Richard Wagner, Sechste Auflage, (München: F. Bruckmann, 1919).

119 Chamberlain, Wagner, p. 323. Chamberlain refers here to Wagner's text Heldentum und Christentum.

120 Chamberlain, Wagner, pp. 324-326.

121 Erich Fromm, Escape from Freedom, (New York: Holt, 1941), p. 194.

122 Erich Fromm was then still unaware of the secret closely guarded by the top leaders of the movement: After future victory, the role of the 'master race' was not to be played by the Germans. Rule of the world was to be given to the future super-race of 'supermen', for which the Waffen SS troops were the breeding ground. 
Taking into account the political importance of racism, it is no wonder that after 1933 it penetrated deeper and deeper into the various areas of public life in Germany. For the purposes of populism and propaganda, the simplified model inherited from the pioneers of this doctrine was quite sufficient. The 'Nordic race, placed at the very top of the hierarchy, was identified only with values then universally deemed positive in Germany, while the exclusively negative qualities were reserved for the 'anti-race ${ }^{123}$ at the other end of the scale - that is, the Jews. To the ideological section of the NSDAP, however, this simple scheme was not enough. Conscious of the weak scientific basis of racist theory and of the impossibility to unequivocally define 'race', from the very moment of taking over power in the state, the Nazis initiated large-scale research aiming to confirm the doctrine and provide propagandist arguments that could appeal to wide intellectual circles. The ideology needed a modernised foundation in the form of an academic infrastructure covering the largest number of disciplines possible. "The great worldview", argued Alfred Rosenberg, the principal ideologist of the Third Reich, is one that can cement all areas of life into one internally integral whole ${ }^{124}$.

Of fundamental importance was the anthropological-medical research carried out at universities and in institutes run by the SS, frequently supported by wellknown German academics, such as the Berlin-based professor of anthropology Hans Günther. Great importance was also attached to historical-archaeological work coordinated by an organisation called Ahnenerbe (Ancestral Heritage) created especially for this purpose in 1933 within the scientific section of the SS and operating under the personal patronage of Heinrich Himmler. The statutory tasks of Ahnenerbe included the study of the space (Raum) inhabited by the old Germanic tribes, the study of the spirit (Geist) and worldview (Weltanschauung) of these tribes, and of the deeds and heritage (Erbe) of the Nordic race ${ }^{125}$.

Artistic studies constituted a separate field. The main assumption was that art is a reflection of the spiritual qualities of a given race. Considering the traditionally prominent role of music in German culture, musicology was to play a particularly important role in this study. "Was ist deutsch" in German music - finding

123 Cf. Yves Ternon and Socrate Helman, Histoire de la Medecine SS ou le mythe du racisme biologique (Tournai: Casterman, 1969). The authors obseve that with the development of concentration camps, the term "anti-race" was applied to all prisoners. Imprisonment meant that the person constituted a threat to the Aryan race.

124 Quoted after: Fritz Reusch, Musikund Musikerziehungim Dienste der Volksgemeinschaft, (Berlin: Zickfeldt, 1938), p. 1: "Eine grosse Weltanschauung ist eine Schau, die eine alle Gebiete des Lebens umfassende innere Bindung schafft".

125 Cf. Ternon-Helman, Histoire de la Medecine SS, pp. 63-66. 
an answer to this question "is becoming an urgent necessity, both from the scientific, artistic and political point of view", wrote Robert Pessenlehner in $1937^{126}$. Karl Blessinger, representative of the extreme anti-Semitic option among musicologists - NSDAP members, formulated this thought even more radically:

"Of all the disciplines which the Jewry has aimed its attacks at, music plays a highly important role. Music is not only an essential expression of the spirit of the nation, but also a key tool of spiritual influence on people. After the Jewry has taken over music, it will control all people who are susceptible to its influence." ${ }^{27}$

As we can surmise, this kind of argumentation met with a particularly favourable response among the NSDAP leaders - because of the regime's anti-Semitic obsessions, but also owing to the German society's universal belief in the special significance of music, seen as superior to other arts. The Nazi ideology may have defiled the fruits of the German Romanticism (as Richard Grunberger claims), but it did inherit the Romantic vision of music as a magic path that leads the soul to eternity ${ }^{128}$. The conviction about the metaphysical mission of music, inherited from the Romantic literary tradition (Tieck, Wackenroder, Hoffman), corresponded well to the vision of music (presented by more recent German writers, such as Thomas Mann) as "the most German of all arts" (Deutscheste Kunst) ${ }^{129}$. In 1936 Walter Gross wrote that, were the German nation to disappear one day and leave

126 Robert Pessenlehner, Wom Wessen der Deutschen Musik, (Regensburg: Bosse, 1937), p. 10.

127 Karl Blessinger, Judentum und Musik - Ein Beitrag zur Kultur - und Rassenpolitik, (Berlin: Hahnefeld, 1944), p. 8: "In dem auf allen Gebieten vorgetragenen Angriff des Judentums auf unsere Kultur and unsere Lebensformen spielt die Musik eine hochbedeutsame Rolle. Denn die Musik ist nicht nur ein wesentlicher Ausdruck der inneren Haltung eines Volkes, sondern darüber hinaus ein entscheidendes Mittel zur seelischen Beeinflussung der Menschen. Wenn der Jude die Musik beherrscht, dann hat er die Menschen. Wenn der Jude die Musik beherrscht, dann hat er die Menschen, die ihrer Wirkung unterliegen, weitgehend in seiner Hand".

128 Richard Grunberger, Historia społeczna Trzeciej Rzeszy, transl. W. Kalinowski, (Warszawa: PIW 1987), p. 295. Eng. original: A Social History of of the Third Reich, (London: Weidenfeld\&Nicolson, 1971).

129 Cf. Albrecht Riethmüller, Musik, die 'deutscheste' Kunst, [in:] Verfemte Musik: Komponisten in den Diktaturen unsers Jahrhunderts, ed. Joachim Braun, Vladimir Kabusicky and Heidi Tamar-Hoffmann, Frankfurt am Main: Peter Lang, 1995, pp. 91-97. It must be remembered, however, that both in the works of Heinrich and Thomas Mann we can find the earliest examples of warnings against the appropriation of the great tradition of German music by nationalist extremists. In his satirical novel Der Untertan of 1919, Heinrich Mann includes a parodistic view of the reception 
behind the scores of its many symphonies, the Mongols who would discover them could perhaps decipher and even perform them, but "would never be able to bring out the emotions and experiences that remain unique to the Germans." 130

Naturally, the regime could hardly remain indifferent to the political and educational-propagandist potential of the deep-rooted belief in the unique spiritual impact of music (shared by a large proportion of the German society). "Of all the arts, music has played the most significant role in the national-socialist revolution", wrote the Nazi professor of pedagogy Fritz Reusch in $1938^{131}$. This special role of music in the service of ideology and the state was then quite widely discussed, and this view was upheld by the party leaders ${ }^{132}$. Undoubtedly the music played in German homes and concert halls had to be racially immaculate. Only large-scale musicological research could guarantee this.

Pessenlehner's and Blessinger's above-quoted statements illustrate the main line of division between the two main trends in musicology under the Third Reich, inspired by racial doctrine. This division reflects the bipolar character of the Nazi hierarchy of races and the dualist theory of Chamberlain. We can thus divide the musicological writings from that time into the following groups:

1. Texts aiming to define the Germanic/Nordic racial features in music. This topic was tackled from different methodological perspectives: historical (inspired by Chamberlain's historiosophy as well as Carlyle's and Nietzsche's concept of the strong being always right), anthropological (based on most recent research) and musical-analytical texts/writings. Anti-Semitism also appears in this group of writings as a Nazi dogma, but its edge is tempered and the awareness of theory and methodology - greater than in the other group.

2. Texts dealing with the "Judentum in Musik". They concern the other end of the Nazi racial hierarchy - the activity of the so-called 'anti-race' in the fields of music composition and performance, music theory and pedagogy, as well as the economic-organisational base of German musical life. These works

of Wagner's Lohengrin by the protagonist, who impersonates those features of the Prussian petty bourgeoisie that underlay the triumph of the Nazis.

130 Walter Gross, Der Rassengedanke im neuen Geschichtsbild, Berlin: Junker und Dünnhaupt 1936, 1942, p. 5.

131 Reusch, Musik und Musikerziehung, p. 1: "Zweifellos hat unter allen Künsten die Musik die unmittelbarste Beziehung zur Kampfzeit und völkischen Erhebung des Nationalsozialismus."

132 Cf. Reusch, Musik und Musikerziehung, Hermann Matzke, Wege zu deutscher Hausmusik, (Breslau: de Wit, 1936), Peter Raabe, Die Musik im dritten Reich, (Regensburg: Bosse, 1935). 
are dominated by the conspiracy theory stemming from extreme, venomous anti-Semitism. Their authors are clearly putting their research at the service of current politics.

We will now move on to a more detailed presentation of the individual publications and the theoretical-methodological standpoints outlined above.

\section{1 “Was ist Deutsch in Deutscher Musik?": Concerning the Germanic and Nordic Racial Features in German Music}

As early as in 1933, the Wrocław-based ${ }^{133}$ musicologist Hermann Matzke ${ }^{134}$ postulated applying the theories of the precursors of racism in the methodology

133 Hermann Matzke (b. 1890 in Breslau [Wrocław], d. 1976 in Konstanz) undoubtedly belonged to the intellectual elite of Lower Silesia in the interwar period. His versatile education and vast scope of activity were impressive. He was a researcher, journalist (mostly a music critic), organiser (of scientific research and music promotion), as well as a musician (conductor and composer). He studied musicology, history, literary studies, philosophy, law, economics and physics at universities in Breslau, Berlin and Bern. He also took private organ, flute and violin lessons, as well as studying foundations of counterpoint and conducting technique. He was a faculty member of Breslau's Technische Hochschule, where he obtained his postdoctoral degree (Habilitation) in 1930 and the post of Professor. It was at that academy that he established (in 1932) the Institut für Musikalische Technologie, and he became head of the institute. It played a major role in the study of the acoustic and technological principles of instrument building, which was Matzke's main field of research along with music sociology. After World War II, he received many accolades and high recognition from the authorities of West Germany. The main source of knowledge about his life and achievements is the website www. hermannmatzke.de, maintained by the scholar's descendants as well as by German organisations that collect documentation for the intellectual life of pre-war Lower Silesia (mainly the Haus Schlesien Deutsches Kultur - und Bildungszentrum). Matzke's texts from the Third Reich period (in which he definitely embraces Nazi views and ideas) have been omitted from his biographical information on the website (Lebenslauf), but listed among all his other publications, where they may easily be overlooked among the huge number of review and press titles. In the Polish Encyklopedia Muzyczna PWM [PWM Music Encyclopaedia], ed. E. Dziębowska, Kraków: PWM, 2000, Vol. “M” which includes an entry for Matzke most likely because of his above mentioned scientific achievements and his contributions to the culture of Lower Silesia - his Nazi writings have tactfully been left out. It is hard to determine to what extent his opinions as presented in those works resulted from his genuine convictions, determined by the "spirit of the time", and to what extent they were a reflection of political conformism.

134 Hermann Matzke, Über Deutschen Musikausdruck und deutsche Musikpflege, (Breslau: Hoppe, 1933), p. 8. 
of modern art studies. In order to establish the features typical of the art of each individual nation and race, wrote Matzke, "culture studies ought to develop in (at least) two directions: one examining the external, formal aspects of art, and the other with its internal spiritual qualities." ${ }^{355}$ This post-Romantic stance - characteristic of Nazi musicology, as we shall see later - led the author to a criticism of the hitherto research on art. In his opinion, it had been too one-sided, concentrated solely on the former, external aspects. "Looking from outside", Matzke admitted, "the history of art appears to be a history of forms and their transformations." ${ }^{136}$. This point of view does not explain, however, what those transformations had resulted from. Matzke believed that they were caused by changes in the 'spiritual content' (Geist-Inhalt), which can only be examined by taking into account the history of the races (Rassengeschichte). Like other Nazi theoreticians of art (e.g. Pessenlehner and Eichenauer), Matzke was aware of the obstacles he would encounter in his research. The most serious of them was race mixing. He claimed that the basic impulse for stylistic transformations occurring in music history comes from the clash of two opposed tendencies: stasis (determined by tradition and heritage) and dynamics (resulting from the fusion of different traditions). Both trends, the static and the dynamic, may sometimes develop parallel to each other. This usually happens when the traditions of one nation or a group of nations merge within one and the same race. The mixing of different races, however, blurs the impact of both tendencies and makes it difficult to discover the regularities in the 'history of the races'.

Matzke interprets this Rassengeschichte (following Chamberlain) as an eternal spiritual 'battle' which must lead to the victory of the 'racially most valuable' culture, which will dominate the 'inferior' cultures. As we can easily guess, the winning culture is to be the German one. Having described the characteristic features of Oriental and African music, Matzke argues that the "Western era in music" (abendländische Epoche der Musik) began with the appearance of the Germanic tribes. It is to them that Matzke attributes the key role in the creation of the "greatest miracle in the history of music" - polyphony, and

135 Matzke, Über Deutschen Musikausdruck, p. 8: "Zur Feststellung der Künstlerischen Eigentümlichkeiten der Volker und Rassen wird die Kunstwissenschaft mindestens zwei Wege ienschlagen müssen: einen von der Form her (von aussen) und einen vom Geist, von der Seele, vom Inhalt her (von innen)".

136 Matzke, Über Deutschen Musikausdruck, p. 8: "Von aussen gesehen ist die Kunstgeschichte eine Geschichte der Kunstformen und ihrer Wandlungen". 
consequently also harmony ${ }^{137}$. It is irrelevant, says Matzke, whether polyphony originated, as different authorities variously claim - in the Netherlands, England, northern France, or northern Germany. All these places are in the North Sea basin, and from the racial point of view, polyphony arose "als Ergebnis einer nordmenschlichen Gefühls - und Ausdrucksanlage." 138

Matzke presents a whole succession of historical facts in such a way as to prove that polyphony is a natural vehicle for the Nordic Rassenempfinden, whose final triumph came with the harmonies of Bach's Das wohltemperierte Klavier. By going beyond the then favoured "vocal style" and reaching the summit of the "instrumental Absolute" (instrumentalen Absolutismus), Bach's masterpiece marked "the triumph of the Germanic spirit"139. Naturally, the immense and unquestionable achievements of German music in the 18th and 19th centuries were interpreted by Matzke as a confirmation of that victory on a spiritual plane. This view is highly characteristic of Nazi writings on music. Matzke admits that most Baroque and Classical forms were invented by Italians and Frenchmen, but claims that it was only German composers who endowed those forms with "the highest spiritual value." The same is true about the opera, he says, since it was Mozart and Gluck that initiated the evolution leading to Wagner's synthesis of arts, typically German in its organic nature.

The history of music in our millennium, according to Matzke, has thus been determined by the 'German spirit' gradually achieving domination. $\mathrm{He}$ interpreted this process as a Darwinist-type evolution leading to progressively higher forms of perfection. As a typically German quality, Matzke quotes the Romantic phenomenon which he calls the faustische Doppelseele, and which he detects in the major-minor and consonance-dissonance polarities, in the opposition of form and content, which Hanslick (as a non-Aryan) apparently could not comprehend. Another racial feature of German music is, according to Matzke, its marked tendency to be rooted in outlook and the supra-physical world which Matzke saw (like Fritz Reusch) as the true source of high artistic quality. All this was supposed to confirm the nationalist thesis that music was "the most German of all arts", which for the Nazis was a reflection of the spiritual qualities of the German race.

137 Matzke, Über Deutschen Musikausdruck, p. 11: „Für die Musik bedeutet der Eintritt der Germanen das grösste Wunder der Musikgeschichte, das Erwachen der Mehrstimmigkeit und damit der Harmonie".

138 Matzke, Über Deutschen Musikausdruck, p. 11.

139 Matzke, Über Deutschen Musikausdruck, p. 5. 
While Matzke directly refers to the 'classics' of racism and uses the manipulation of historical facts as his main methodological tool, Richard Eichenauer's Musik und Rasse ${ }^{140}$ represents a different, anthropological-historical trend. Eichenauer developed the methodological and theoretical foundations of his research by reference to the most recent studies in physical anthropology. Following the typology of European races presented by the already mentioned Hans Günther ${ }^{141}$ - a leading representative of the German Rassenkunde - Eichenauer attempts to establish what musical qualities should be considered as characteristic of each of the six types. Since, as he argues in the introduction, nobody can doubt that there is a fundamental difference between the music of the 'white race' and those of non-European cultures, he finds it proper to examine how racial conditioning works within European music itself. Fundamental to this question is his conviction that spiritual differences between races are just as clear and easy to define as the physical ones, and that both these spheres - spiritual and physical - are permanently interrelated. Quoting Ludwik F. Claus ${ }^{142}$ as his methodological model, Eichenauer prints portraits of artists considered as eminent composers in the history of music, and then classifies them on the basis of their physiognomies using Günther's typology. This research procedure is to serve as a basis for a confrontation of the results of stylistic analyses with the physical features characteristic of each racial type. However, as the author himself warns, conclusions from such comparisons can only be drawn very cautiously. "If the physical image of the given race (Rassenbild) coincides with the spiritual one, it only makes the diagnosis concerning that latter aspect somewhat more probable." ${ }^{143}$ On the other hand, the absence of such a concomitance does not automatically make our identification of the spiritual aspects incorrect since races frequently mix. In the case of historical research, the lack of reliable objective visual representations of composers from the past is naturally a major limitation.

Another method of identifying the race of composers applied in Nazi musicology (indicated by Kurt Gerlach) ${ }^{144}$ was the study of documents in order to establish their ancestry, many generations back. However, as Eichenauer

140 Richard Eichenauer, Musik und Rasse, (München: Lehmann, 1937).

141 Hans Günther, Rassenkunde des deutschen Volkes, (München: Lehmann, 1930).

142 Ludwig F. Claus, Die Nordische Seele, (München: Lehmann, 1936).

143 Eichenauer, Musik und Rasse, p. 15. "Stimmen körperliches und geistiges Rassenbild überein, so wächst die Wahrscheinlichkeit dass das letztere vom Beurteiler richtig gesehen ist”.

144 Kurt Gerlach, Begabung und Stammesherkunft im deutschen Volke, (München: Lehmann, 1929). 
observed, this method could also frequently fail. Besides, apart from identifying a composer's racial features, how are we supposed to establish that the 'spiritual attitude' (Seelenhaltung) of the given piece is "Nordic, Baltic or Dinaric"? Eichenauer refers to the methodology used in works dedicated to the graphic arts and poetry ${ }^{145}$. Nevertheless, comparisons of the artist's racial features with his or her preferred ways of presenting landscapes, people and objects can only be applied to musical research to a very limited extent since music represents "menschliche Seelenregungen, Gemütszustande und Gefühlsentwicklungen" rather than material objects. ${ }^{146}$ Eichenauer proposes therefore (after Ludwig Schemann ${ }^{147}$ ) that we should compare the stylistic qualities of a given musical work and the vaguely defined "overall spiritual impression" (Seelischen Gesamteindruck) left by this work with the "spiritual image" of the given race as described by scholars from other disciplines of art, as well as psychologists and anthropologists. Eichenauer realised quite well that the seelischer Gesamteindruck inevitably sounds like a subjective impression. Therefore he postulated that the relations in question should be established on the basis of the largest possible number of analyses.

The above-presented methodological assumptions led the author to similar conclusions as those proposed by Matzke, though presented with rather less chauvinistic exaltation and more semblance of scientific objectivism. $\mathrm{He}$ attempts to demonstrate the historical significance of the struggle between alien (non-European) and Nordic-Germanic racial elements, which, he claims, was particularly violent in the first millennium CE. In historical development, those alien elements were overcome, particularly with the dawning of the age of polyphony. Like Matzke, Eichenauer viewed European polyphony as a Nordic invention and a characteristic indicator of the spiritual qualities of the Nordic race. This is supposedly confirmed by the physical traits of the majority of eminent composers of polyphonic music (for instance, Palestrina is characterised here as "dinarisch - nordisch", Willaert - as "vorwiegend nordisch mit dinarischem Einschlag", etc.) Transplanting Lorenz's theory of the development of musical forms onto racist grounds allows Eichenauer to conclude that every great Nordic composer, even in the age when homophonic textures were still predominant, betrayed a predilection for 'polyphonising' as his style matured. However, since this generalisation is obviously too arbitrary, the author himself

145 Hans Günther, Rasse und Stil, (München: Lehmann, 1926); Paul Schulze-Naumburg, Kunst und Rasse, (München: Lehmann 1935).

146 Eichenauer, Musik und Rasse, p. 16.

147 Ludwig Schemann, Rasse in den Geistwissenschaften, (München: Lehmann, 1930). 
decides to ask the question which every German reader could inevitably have asked: If polyphony is the defining quality of Nordic music, why is it that the Viennese classics departed from this style? At this stage in historical development - the author explains reassuringly - departure from polyphony meant that the 'outmoded' (überreift) technique was abandoned in favour of new tendencies which made room for creativity. And it is creative action that best characterises the Nordic race ${ }^{148}$.

Yet another methodological perspective is represented by works whose authors postulate a racial characterisation of German music based on analyses of the musical works themselves. This school could be labelled as autonomousanalytic. It is exemplified by the book Vom Wessen der Deutschen Musik written by Robert Pessenlehner ${ }^{149}$, who set out to examine the specifically German qualities of the great German music tradition from J.S. Bach to Wagner. His aim was to capture the historically stable, unchanging elements, appearing independently of stylistic and technical transformations. By comparing Vivaldi's compositions and their arrangements by J.S. Bach, Pessenlehner opposed the clarity and simplicity of Italian music to the typically German tendencies to complication and monumentalism. It is these tendencies, he claimed, that motivated Germans more than other nations to write intricate polyphony, which Pessenlehner - like the authors discussed above - saw as a distinguishing racial quality. He quotes the opinions of 18th-century French and German critics and who concluded paradoxically that "to be German means to be unclear"150. This conviction, claims Pessenlehner, resulted from a common misunderstanding; in fact, when taking over and adopting foreign forms, the German masters demonstrated immense artistic ingenuity. Rather than copying those forms, they transformed them in the German spirit, and were therefore accused of obscurity. This, however, is only "apparent obscurity" in the case of the greatest masters, he claims and presents as proof his detailed formal analyses of J.S. Bach's Brandenburg Concerto No. 1 and St Matthew Passion, the finale of Beethoven's Symphony No. 9 as well as Wagner's Rheingold. Despite historical differences, he argues,

148 Eichenauer, Musik und Rasse, pp. 212-214. More on Eichenauer's personal career as a Nazi fanatic and on the history of racial obsessions in the study of polyphony, in: Karen Painter, "Polyphony and Racial Identity: Schönberg, Heinrich Berl, and Richard Eichenauer", Music and Politics, Vol. V issue 2, summer 2011 http://quod.lib.umich. $\mathrm{edu} / \mathrm{m} / \mathrm{mp} / 9460447.0005 .203$ ?view=text;rgn=main (accessed 24th September 2015).

149 Regensburg 1937.

150 “Deutsch sein heisst unklar scheinen", Pessenlehner, Vom Wessen p. 80. 
despite monumentalism and technical complexity - all these works demonstrate a symmetry of the formal-dramatic plan, which is a key racial determinant of German music.

In the field of rhythm, says Pessenlehner, a good example of "apparent obscurity" is the use of syncopation. He compares examples of melodies from the works of Pauman, Finck, Froberger, J. S. Bach, Mozart, Beethoven, Schumann, Brahms, and Pfizner and quotes Arnold Schering's studies of Lutheran chorales. At the same time, he arbitrarily dismisses the obvious fact of syncopation being present in the music traditions of other nations as evidence of the influence of German music. He sees the syncope as a kind of German 'racial symbol' and concludes that, thanks to the use of syncopation, we may distinguish Aryan from non-Aryan composers on the German music scene. Despite all efforts to assimilate it, "non-Aryan artists have failed to make this symbol their own". He quotes Mahler as an example of a composer whose entire output of compositions was apparently a struggle to apply syncopation in the same way as in the music of Aryan composers. Aware of the extremely controversial character of this thesis among others, in the context of the origins of jazz - Pessenlehner categorically states that jazz was invented by the American music industry and had nothing to do with genuine Negro folklore. Curiously enough, he explains jazz syncopation with one of the favourite Nazi conspiracy theories which they used to explain politically or ideologically inconvenient facts: "It is certain that in the case of jazz the aim was a degeneration of the symbol of German music."151

What is striking about Pessenlehner's research is the contrast between his analytic competence in details and the arrogant, nearly arbitrary character of his general conclusions. Josef Müller-Blattau ${ }^{152}$, on the other hand, seem to come closer to our modern standards of scientific discourse. He analysed the melodic structures of the oldest preserved melodies from the Germanic times, and described characteristic turns (interval progressions and contours of movement). He later examined the use of the same kind of turns in German medieval secular and ecclesiastical songs, folksongs and artistic German music until the mid-18th century. His research culminated in a chapter dedicated to the works of the most 'Germanic' of German composers, in whose music Müller-Blattau also found numerous examples of melodic turns rooted in old Germanic songs.

151 "Gewiss ist, das sich bei der Jazzmusik zum Ziel um die Entartung eines Symbols der Deutschen Musik handelt". Pessenlehner, Vom Wessen, p. 104.

152 Josef Müller-Blattau, Germanisches Erbe in deutscher Tonkunst, (Berlin: Vieweg \& Teubner, 1938). 
This is how, according to this author, the continuity of the Germanic tradition manifested itself in German music. This continuity, he claims, was motivated by racial identity.

\section{2 'Judentum in Musik' - Around the Musical Activity of the 'Anti-Race'}

When the Nazis seized power in Germany, antisemitism had already had a deep-rooted tradition in the country. Its origins and causes were extremely complex, related to social, political, economic, cultural, religious, psychological factors as well as to the ideological doctrines discussed above ${ }^{153}$.

Anti-Jewish sentiments were particularly strong during the Great Crisis, which created a social basis for the dissemination of ideologies previously limited to a part of the German elites. As mentioned above, the Volkist milieux had long been convinced that the Jewish character, determined by the desert landscape, was faulty in its creative dimension and lacked spiritual depth. They also saw the great modern cosmopolitan cities, which were a natural environment for the Jews, as dangerous for the spirit of national community. "Between the sands of Eastern deserts and the modern stone deserts of the West there is only a difference of degree, but not of essential character"154, wrote Heinrich Berl in 1926. The identification of Jews with the avant-garde in art (and consequently with the dismantling of traditional artistic values) was common enough (also outside Germany); Karol Szymanowski polemicised this view in his writings ${ }^{155}$.

However, the assessment of the role of Jews in music was far from unequivocal until the Third Reich era. Apart from threats, some authors also saw positive elements. One example is the 1926 book publication Das Judentum in der Musik by the already mentioned Heinrich Berl. The title of this highly peculiar attempt at transplanting the ideas and methods of Husserl's phenomenology onto the field of Volkist thought was borrowed from Wagner, whose view of the Jews as a foreign body' (Fremdkörper) in the music culture of the West, Berl accepts as correct. The question is, Berl writes further, what role this 'foreign body' plays, whether positive or negative. Before answering this question, he engages in an extensive discussion

153 The role of these individual factors has been discussed in more detail in: Mosse, The Crisis, Fromm, Escape, Grunberger, A Social History.

154 Heinrich Berl, Das Judentun in der Musik, (Stuttgart: Deutsche Verlags-Anstalt, 1926), p. 43: "Zwischen der Sandwüste des Orients und der modernen Steinwüste des Okzidents ist nur ein gradueller Unterschied, kein prinzipieller".

155 Cf.: Szymanowski, "Kwestia żydowska", pp. 225-240. 
of differences between Eastern and Western music. Later he proposes the thesis that the music of European Jews belongs spiritually (Seelisch) to Eastern, but morphologically - to Western culture. This, he claims, does not contradict the Volkist doctrine of artistic work being determined by qualities of landscape, though the Jews have undeniably created their art for many centuries in many varied types of landscape. However, Berl asserts that the primacy of the Landschaft only concerns the spiritual, not the morphological qualities of music, and the former are similar in all Jewish music regardless of the geographic context in which they live. The spirit of the desert (die Seele der Wüste) ${ }^{156}$ manifests itself everywhere in their case. A nation formed in the desert will preserve its original qualities despite wandering and settling in other types of landscape.

Berl uses the terms of phenomenology in an attempt to present this phenomenon from a theoretical perspective: "Jewishness in music is nothing else but a problem of Oriental pseudomorphosis inside Western music." ${ }^{157}$ By 'pseudomorphosis' he means that a different noumen, a quite different essence is concealed behind the given artistic phenomenon. "For me, music is eidetic in Husserl's understanding of the word," Berl explains, "which means that it is independent from the world of phenomena, though it manifests itself through that world." 158 In this sense, "pseudomorphosis is only a world of mechanical, not of organic phenomena, of phenomena freed from [the essence of] being."159

Berl accepts that the Jews are a non-organic population among nations that organically grew in the given area, but warns against accusing them rashly of negative influence on European culture. He suggests that the widespread conviction about their creative impotence is rooted in the view that their race demonstrates no graphic-spatial talents. What specific technical-musical features distinguish Jewish music from its European context? According to Berl, it is the definite primacy of melody over harmony. Oriental cultures place temporal over spatial phenomena. For this reason the Jews, who are apparently "deprived of the spatial sense" are prone to perceiving harmony as a sum total of melodic lines, but never think in terms of autonomous harmonies consisting of a number of sounds. This

156 Berl, Das Judentun. p. 18.

157 Berl, Das Judentun p. 17: "Das Judentun in der Musik ist nicht anders als das Problem einer morgenländischen Pseudomorphose innerhalb der abendländischen Musik".

158 Berl, Das Judentun, p. 13: "Musik ist für mich - im Sinne Husserls - eidetisch, was bedeutet, dass siê unabhängig von Erscheinungswelt ist, obwohl siê sich durch die Erscheinungswelt manifestiert".

159 Berl, Das Judentun, p. 13: "Pseudomorphose ist nun eine Welt der mechanischen, nicht der organischner Erscheinung, der Erscheinung, losgelöst vom Wesen”. 
is also a consequence of their subjective-synthetic rather than objective-analytic way of perceiving reality. As a consequence, Jews prefer that element of music which is directly related to the projection of emotions - that is, melody. Another reason is (here Berl reiterates a then popular stereotype) that Jews are lyrical, not epic artists by nature. And melody is the lyrical component.

However, Berl does not share Wagner's view that the Jews pose a threat to European music. Quite the contrary - he claims that while Strauss and Pfitzner took the Wagnerian tradition to absurd levels and dealt it a mortal blow despite glorifying it, it is "Mahler and Schönberg [who] give music a new impulse and a new life basing on the worlds of rhythm and melody." Already Nietzsche had foreseen that Wagner brought a certain era to a close. Tristan was the swan song of European music, and at the same time - the point of departure for the music of the future, of which Schönberg is a pioneer. Despite his methodological eclecticism and a sometimes unclear line of thought, we may assume that for him the principle of the primacy of landscape (filtered through popular 1920s stereotypes) concerned only some selected aspects of music - namely, those related to the sense of space, of which Jews were supposedly devoid. On the other hand, his final conclusions suggest that the Seele der Wüste (conceived as the cause of a phenomenologically understood pseudomorphosis) makes the artistic music of the European Jews different but not inferior. This contradicts the claims of strictly racist theories for which the cultural pseudomorphosis as described by Berl could only be a negative phenomenon. Though Berl and the Nazis agreed in calling the Jews a Fremdkörper, his conclusions could not meet with a positive reception in the Third Reich, because the Nazi view of the role of Jews in European music was closer to that of Wagner than that of Berl.

As I have already explained, studies of 'Judentum in Musik' were taken very seriously in the Third Reich, especially in the late 1930s, when the supporters of the extermination of the Jews began to dominate the Nazi party policies ${ }^{160}$. Such studies, officially approved of and marked as a political priority, were conducted by many institutions including, among others - under the auspices of the Institute for the Study of the Jewish Question (Institut zur Erforschung der Judenfrage) and the Music Chamber of the German Reich (Reichsmusikkammer). The result

160 Cf.: Ternon - Helman, Histoire de la Medecine SS; on the legal status of musicians of Jewish origin after the Nuremberg Laws came into force, see also: Ewa Hanau: "Die musikalischen Aktivitäten des Jüdischen Kulturbundes in Frankfurt am Main”. In: Joachim Braun and others (ed.), Verfemte Musik, (Frankfurt am Main: Peter Lang, 1995), pp. 79-87. 
of these studies was a monumental six-volume edition of the Lexikon der Juden in der Musik ${ }^{161}$ - commissioned by the NSDAP leadership and supplemented by a nearly one-hundred-page long catalogue of Jewish music compositions (including film and popular music). Another publication of this type (i.e. aiming at a racial 'purification' of German music life) was Christa Rock and Hans Brückner's lexicon Judentum und Musik, printed in Munich in 1936 ${ }^{162}$. A full presentation of the officially approved views on the role of Jews in German music can be found in the book Judentum und Musik ${ }^{163}$ by the previously mentioned Karl Blessinger.

The Nazi perspective on this issue combines extreme anti-Semitism with the nationalists' thesis about music being the Deutscheste Kunst. Both of these views are presented here from a distinctly political point of view. Central to this view is the conviction that the central aim of the international Jewry is control over the world (Weltherschaft). In order to achieve this control the Jews have, since the 18th century, systematically penetrated all the fields of economic and cultural life in various European countries, particularly in Germany as that continent's greatest power. Since music plays an especially significant role in German culture, its gradual penetration by the Jews becomes a political problem. The spiritual power gained by controlling German musical life can make it possible for Jews to obtain political power as well. The Nazi interpretation of the general principles of music history as well as individual phenomena was subordinated to this fundamental thesis. The politically-involved racial doctrine thus permeated music aesthetics, theory of musical forms, as well as the interpretation of social and economic phenomena that influenced artistic trends and supraindividual styles. Just as real socialism cherished the theory of 'class struggle' or 'warfare', the dogma of national socialism was that of racial warfare understood in terms already outlined by Chamberlain, but now definitely political and determining the interpretation of events in all areas of public life in accordance with totalitarian state doctrine. As mentioned before, the main two opponents in

161 Lexikon der Juden in der Musik, ed. Theo Stengel and Herbert Gerigk,(Berlin: Hahnefeld, 1944). The contents of this curious publication are discussed in detail by Jan Stęszewski in his paper "Lexikon der Juden in der Musik" z perspektywy współczesnej i polskiej ["Lexikon der Juden in der Musik" from the Contemporary and the Polish Perspective], [in:] Muzyka i totalitaryzm, ed. Janina Tatarska, (Poznań: Akademia Muzyczna, 1996), pp. 48-59.

162 Christa Rock, Hans Brückner, Judentum und Musik: mit dem ABC judischer und nichtarischer Musikbeflissener, (München: Hans Brückner, 1936).

163 Berlin 1944. 
this warfare were Germany as the racial aristocracy among Europe's 'non-Jews' ('Nichtjuden' - a term consistently applied by Blessinger) and the international Jewry preying on the cultures of its European hosts, aiming to decompose and falsify (Verfalschung) their spiritual values. Its activity leads to a loss of racial instinct (Rasseninstinkt) and thus to the loss of the spiritual - consequently also political - self-determination of the nations of Europe.

Blessinger's second initial assumption is the claim (taken from the Volkist tradition) that Jews are artistically impotent. In the Nazi interpretation, the principle of the primacy of landscape was replaced with doctrine of 'impure blood' as the source of genetically determined creative impotence. Such an explanation sounded more modern and was politically more convenient, since it avoided placing Jews on a par with the desert nations of Asia Minor. "It should be considered," warns Blessinger, "that Jews stand in sharp racial contrast to the nations of their original [geographic] environment, because their blood is - in comparison with those nations - impure and degenerate." 164 This was supposed to result from their wandering lifestyle, lack of rooting, and the mixing of races. Artistic impotence was understood as the inability to engage in any other activity but that which led to the decomposition of the host cultures.

What did this decomposing effect consist of, and how was it supposed to lead to a loss of self-determination?

As mentioned before, Nazi musical aesthetics fought against Hanslick's formalism and did not accept autonomous treatment of art. "The greatest artistic achievement of the West is not 'beauty', but a work of art whose external element is permeated by spiritual force of impact," claimed Rosenberg ${ }^{165}$. Matzke confirmed: "We [the Germans - note AT] value unique character more than form." ${ }^{166}$ As for the Romantics, form was viewed only as the external 'lining' of the musical work. Music's content was the vaguely defined spiritual element which, according to the Nazis, expressed the spirit of the national community and was therefore an artistic reflection of the emotional and intellectual

164 Blessinger, Judentum, p. 143: "Es ist (...) zu berücksichtigen, dass das Judentun $\mathrm{zu}$ de Völkern seiner ursprünglichen Umgebung rassisch insofern in einen scharfen Gegensatz steht, als sein Blut im Vergleich zu diesen Völkern unrein und degeneriert ist ..."

165 Quoted after: Reusch, Musik und Musikerziehung, p. 32: „Das höchste Kunstwerk des abendlandes ist nicht ein 'Schönes', sondern das Werk, welches das Aussere mit seelischer Stosskraft duerchsetzt".

166 Matzke, Über Deutschen Musikausdruck, p. 9: "Wir schätzen Charakteristik mehr als Schönheit, Gehalt mehr als Form.” 
qualities characteristic of the given race, which can only be represented in music by an irreproachable representative of that race. The assimilating Jews, claimed Blessinger, can at best absorb the external (formal) features of German music, falsifying at the same time its spiritual content. The internal order of the work and balance between its external and internal components is disturbed in this way. Consequently the work loses its bond with the national community and no longer fulfils its positive culture-building function. Rather than reinforcing the characteristic qualities of the German nation (such as idealism, valour, discipline and creative sense), it begins to act as a medium of alien and hostile indoctrination.

Meeting the racial criteria by a given composer is not sufficient, however, to fully protect his audience against the influence of Jewish music. Blessinger asks:

"Where, for instance, can any fundamental difference be found between the virtuoso pieces of the Jew Herz and those of the non-Jew Hünten, or between the atonal experiments of the Jew Schönberg and those of his Arian pupils?"167

He answers this question as follows: Even racially irreproachable German composers may become tools in the hands of Jews if they have lost their racial instinct. The decomposing virus is transmitted from teacher to pupil and eats up the 'healthy tissue' of national culture. This process makes it easier for the Jews to cover up the traces of their destructive impact, confuses the public and - most importantly - ensures the effectiveness of their work. This sensation-oriented conspiracy theory concerning music history led Blessinger to formulate the postulate of examining the racial origins of new composition techniques. "We do fight the Jewish spirit," he wrote, "wherever it manifests itself, and most severely where it penetrates like a poison into our own nation." ${ }^{68}$ His thesis, which he attempts to prove through tendentious interpretation of historical facts, is that the Jews began to penetrate into Prussia's musical life during the reign of Frederick William II, and took place on many levels. It began, Blessinger claims, by gradually taking control over the economicorganisational basis of musical life and over the opinion-forming circles. The press (which was getting more and more powerful) played a major role in this

167 Blessinger, Judentum p. 9: "Worin liegt z. B. der wesentliche Unterschied zwischen den Virtuosenstücken des Juden Herz und des Nichtjuden Hünten, zwischen atonalen Experimenten des Juden Schönberg und seiner nichtjüdischen Schüler?”

168 Blessinger, Judentum, p. 9: “... wir bekämpfen ja den jüdischen Geist, wo er sich auch zeigen möge, und am schärfsten da, wo er als Giftstoff in unser eigenes Volk eingedrungen ist". 
process, as did the power of Jewish money. The rich Jewish bourgeoisie of Berlin opened its salons to both the people in power and the Prussian intellectuals. Vivid social interest in art helped the Jews penetrate both into the political and artistic elites. Through these salons, and through the press they controlled, the Jews could consequently promote their own music performers. Then came the time to penetrate into the most important field of German music life - that of composition. Blessinger distinguished three historical stages in this process of 'disintegrating work' (Zersetzungswerk):

1. The organic unity of European cultural heritage is disrupted. Its various parts preserve only their external formal links, but lose the internal bond. For this period, the characteristic figure was Mendelssohn, and the dominant tendency - that for assimilation, which 'camouflaged' the Jewish origins.

2. The various elements of heterogeneous origin form a compilation devoid of deeper meaning, motivated only by current commercial aims. Characteristic of this period were the operas of Meyerbeer and, generally speaking, the artistic activity of German Jews who settled in Paris.

3. The 'camouflage' is discarded; Talmudic pettifoggery and a 'magic' pose are presented as the final achievement of Nordic philosophy and worldview. The most eminent representative of this trend was Mahler, whose work led to the disruption of Western musical sound order and its replacement by 'chaos', eventually elevated by Schönberg to the rank of an aesthetic principle.

As we can see from the above, in Nazi thought about music the idea of 'organic unity' became one of the key distinguishing marks of Aryan origins ${ }^{169}$. As evident in Blessinger's line of argument, this notion was applied to three basic fields:

169 The ideas of 'organic nature' or 'organic unity' appear in all the texts discussed here to define qualities characteristic of German, Nordic or - most generally - Aryan music. It should be noted that apart from German music theory, the same concepts also functioned in Volkist thought, where 'organic unity' was a mystic union of the individual, the Volk, the landscape and cosmic forces. It was such unity that the German nation strove for. Moreover, "'organic means artistic," as Langbehn would argue (cf.: Mosse, The Crisis., p. 64). In this context it is interesting to note that during the severe crisis in the last years of the Third Reich, when total war made it necessary to close down most magazines dedicated to culture, Herbert Gerigk proudly announced that the Muses did not go to sleep for this reason, because, while other nations may see culture as a kind of rest, for the Germans it is 'organically essential.' Herbert Gerigk, "Schweigen die Musen?" In: Musik im Kriege, II/7-8 (1944) p. 121, cf. also: Karen Painter, "Musical Aesthetic and National Socialism", in: Music and Dictatorship in Europe and Latin America, eds. Roberto Illiano and Massimiliano Sala, (Turnhout: Brepols), 2009, pp. 121-140. 
1. harmonic-tonal, related to the organisation of harmonies

2. formal-architectural, referring to the sum total of relationships between the various formal constituents and the whole.

3. aesthetic-social (these two aspects were virtually inseparable in the Nazi state) - comprising the work's value and a wide range of supra-individual style developments in the context of the organic bond between music and the national community.

\subsection{Organic Harmonic-Tonal Unity}

Blessinger saw the principle of tonal unity as one of the key features of the German tradition in music, regardless of the intensity of modulations and the saturation of music with chromatic elements. He considered Wagner's music as the greatest achievement in this area, arguing that harmonic innovations never led to a loss of tonal unity in his works. He quotes Wagner's own statements to demonstrate that the composer instinctively avoided two extreme tendencies that could lead to the disruption of tonal unity ${ }^{170}$. Naturally, according to Blessinger, both these tendencies originated in Jewish circles. The first - a conservative one - was allegedly promoted by Mendelssohn and Hanslick. The other extreme was represented by supporters of "progress at any cost", with Adolf B. Marx as its initiator and advocate. The former tendency resulted in ossification and monotony, while the latter led to conscious breach of all the rules passed down by tradition. Consequently, both these extremes were to cause the breakdown of the system on which the Western music tradition was based. The principle of tonal unity - as a product of artistic intuition, not of intellectual speculation - was therefore presented as one of the foundations of Aryan music culture.

Another factor which undermined the sense of tonal unity was - according to Blessinger - the dismantling of the organic bond between melody, harmony and counterpoint. Also in this case, Blessinger saw the cause of this 'decomposition' as related to the activity of composers and theoreticians of Jewish origin. "Mahler was above all the one who led the voices without care for the harmonies that resulted," he claims, and quotes the sentence (attributed to Mahler) that "Es gibt keine Harmonie, es gibt nur Kontrapunkt." ${ }^{171}$ Just as the previously cited Berl, Blessinger expressed the conviction that linear writing without a solid

170 Blessinger, Judentum, p. 150.

171 Blessinger, Judentum, p. 111: "Vor allem Mahler war es, der eine rücksichtlose Stimmführung ohne Beachtung des Klanges pflegte". 
harmonic basis is a trademark of Semitic music. In Nazi aesthetics, this linearity is presented as a deliberate attempt to decompose the system, of which not only composers of Jewish origin, but also racially 'impure' theoreticians were accused. The latter's subversive work depended on 'false interpretations' of the masterpieces of German music. The falsehood consisted in attributing to those musical works such technical norms which were alien to the spirit of German tradition. Blessinger sharply attacked Schenker for his 'myth-creating' (sagenhaft) concept of the Urlinie (p.125) and for discovering linear voice leading in improbable contexts ${ }^{172}$. His criticism of Kurth was even more severe. Blessinger claimed that Kurth's concept of 'linear counterpoint' not only distorted the true meaning of Bach's polyphony, but led to chaos in new German music. Kurth was similarly criticised (though without venomous anti-Semitic comments) by Matzke, who categorically stated that in German music there had never been any 'linear polyphony'. Every German type of linear writing, he explained, had a more or less distinct harmonic dimension. "Polyphony without a harmonic basis becomes anarchy," Matzke warned, and concluded ominously that linearity and atonality were invading German music from alien cultural space ${ }^{173}$.

\subsection{The Organic Unity of Formal Structures}

Concerning the formal-architectonic aspect of organic unity, Blessinger postulated the existence of a sharp contrast between organic form in the German sense and Jewish formal constructs. ${ }^{174}$ The German creative genius conceives of the work of art as a living whole - a universe in which every detail (independent of its own significance) is subordinated to that whole. Form develops through a series of clear and definite culminations (Höhepunkte), between which one can find equally distinct moments of calm (Ruhepunkte). The different themes are organically interconnected, regardless of whether the secondary theme stems out of the main one or complements and sharply contrasts it in terms of expression.

172 In the context of these Nazi attacks, one should note Schenker's paradoxical stance aptly defined by Maciej Gołąb as 'aggressive Teutonism. “There is something paradoxical," wrote Gołąb, "in the fact that Schenker's pan-Germanic theory was banned by Nazi censorship because of his Polish-Jewish roots." (Cf.: Maciej Gołąb, "Analiza i dzieło" [Analysis and Work], Muzyka No. 4, 1986, p. 37). Schenker also claimed that Chopin's genius had more in common with German than with Polish culture (cf.: Ian Bent, "Heinrich Schenker, Chopin and Domenico Scarlatti", Music Analysis V/2-3 1986, pp. 131-149.

173 Matzke, Über Deutschen Musikausdruck, p. 23.

174 Blessinger, Judentum, p. 70. 
In both cases, they form an organic whole. The symphonic forms of the German classics characteristically develop in the shape of vast arches that correspond to the monumental quality of 'German sentiment'. This element is missing from the works of Mendelssohn, Meyerbeer and Mahler - the three most eminent composers of Jewish origin, whom Blessinger - in accordance with the racist principle of genetic determination - treats as representative examples of the whole 'anti-race'. Jewish composers are incapable of grasping form as a whole. In their music, form is the sum total of details which never make up organic unity. Mendelssohn seems to be the closest to the German tradition, but in his case form was mechanically taken over from the German masters and, instead of acting as 'the outer shape of a living organism' becomes a 'fossilised norm' which reduces the will to develop freely ${ }^{175}$.

The most important quality that distinguishes German music in formal terms from the Jewish ones is the German tendency to use dynamic forms as opposed to static forms in Jewish compositions. This tendency manifests itself in the predilection for mechanical repetitions, especially of the individual motifs, which is allegedly typical of Jewish music. Blessinger admits that such repetitions are also present in Aryan music, including German works. However, in German music every repetition of a motif is related to an increase or decrease in the tension, and is therefore part of the overall formal development. In Jewish music, on the other hand, repetitions keep the music on the same level. Blessinger sees here an analogy to Oriental magic charms, which characteristically makes him conclude:

"A formula that is incessantly repeated in this way leaves an indelible mark on the listener and he cannot get it out of his head. This is how the Jew attains his goal; his music takes possession of the man against the latter's will,.176

The racial foundations of the process of dismantling the organic unity of form had yet another aspect, Blessinger claimed; namely, the distortion of relationships between the components related to pitch (melody, harmony, and counterpoint) and the elements of rhythm and sound colour. In the German music tradition, rhythm organically grew out of, and was subordinated to, the melodic progressions, while in 20th-century music it gained more and more independence until it came to dominate some styles such as jazz and selected trends

175 Blessinger, Judentum, p. 71.

176 Blessinger, Judentum, p. 70: “... eine Formel, die so unablässig wiederholt wird, prägt sich dem Hörer unauslöschlich ein und will ihm nicht mehr aus dem Kopfe gehen. Und damit hat der Jude seinen Zweck erreicht: seine Musik ergreift Besitz von den Menschen selbst wider deren Willen". 
in European contemporary music. This process began, according to Blessinger, with the operas of Meyerbeer and the operettas of Offenbach, which he criticised for the exaggerated exposition of rhythmic formulae. However, also in this area he attributed the strongest impulse for further 'disintegrating activity' to Mahler, and in particular - to his Symphony No. 7. He dismissed Mahler's characteristic combinations of instruments as 'absurd', and his sound colours as 'aggressive' and 'garish'. Blessinger even went so far as to see in Mahler the origins of "modern American-Jewish dance hits." 177

\subsection{The Organic Aesthetic-Social Unity}

In the aesthetic-social context, the idea of organic unity concerned the link between specific stylistic tendencies and the life of the national community, as well as propagandist and educational aims. Blessinger analysed the progressive alienation of artistic music from society since the early 19th century and attributed this process to the 'disintegrating work' of the Jews, making them responsible (as the Volkist theoreticians before him) for all the negative consequences of modern life. It was Romanticism that, by embracing the unusual and exotic, allowed racially alien artistic phenomena to penetrate freely into European culture, he argues ${ }^{178}$.

In the social context, this phenomenon was facilitated by the emergence of the free market for artistic goods, whose anonymity made it possible for Jewish organisations to take over that initiative. From that time on, the phenomenon of 'forgotten genius', unknown in the feudal era, became more and more common, while those Aryan artists who did not lose their 'racial instinct' had to struggle with influential music critics, who represented Jewish interests in most cases. The destructive function of the 'Jewish conspiracy' can be summed up in this context as follows: While progress in art is desirable and inevitable, it must not violate the organic bond between art and the national tradition. It was the spirit of the national community that inspired one of the 19th century's greatest innovators - Richard Wagner. His example proves that there is no contradiction between modernity, originality and bond with the nation. However, the Jews, motivated exclusively by commercial and political aims as well as by the current intellectual fashions which they created - imposed aesthetic ideas that praised modernity for its own sake. In this way, they triggered a sequence of stylistic transformations that isolated music more and more completely from society.

177 Blessinger, Judentum, p. 140.

178 Blessinger, Judentum, p. 36. 
This isolation was a kind of 'self-defence mechanism' and resulted from the 'racial instinct' of national communities. Since contemporary European artistic music could only have a limited social impact, the Jews began to expand their activity in the field of popular music (especially in the United States), which also brought them - apart from influencing the social masses - substantial profits in financial terms. It was the rhythm-dominated American Schlagerstill that proved most problematic to Nazi musicologists and educators. The fact that this racially 'degenerate' music was immensely popular among the German population, especially among young people - was extremely inconvenient, because it contradicted the thesis that the racial instinct of the masses is infallible and undermined the doctrine that racially correct music was organically related to various forms of life in the national community. The role of this collective racial instinct was stressed by the previously quoted Nazi professor of music pedagogy, Fritz Reusch, who ostentatiously condemned all intellectual speculation in music and postulated focusing on that kind of style whose racial purity and link to the mythic Volsksgemeintschaft are indisputable: namely, Prussian military marches and German folk music ${ }^{179}$. Especially the latter, as a spontaneous expression of 'life itself' and of the spirit of German community, was recommended for use in young people's education. It could not be denied, however, that youth from large cities favoured jazz and American dance music ${ }^{180}$. This contradiction was

179 Reusch, Musik und Musikerziehung, pp. 2-7. The author stressed the positive role of march rhythms in the fight against symptoms of undesirable individualism.

180 One should note that the place of jazz (or rather - of American syncopated dance music then commonly referred to as jazz) in the life of the Third Reich was a rather complex matter. Apart from the huge gap between Nazi ideologies and educational doctrines on the one side and the wide masses of young people on the other, there was an equally striking difference of approach among the high dignitaries of the Nazi state, many of whom loved entertaining themselves with the sounds of American hits played by dance orchestras. As Will Studdert's most recent study suggests, Goebbels himself preferred a 'pragmatic' approach to this issue, so that the young Germans would not tune in to Anglo-American radio stations. After the outbreak of the war, this problem became a propagandist priority, so German radio launched a broadcast series entitled Frohe Stunde Am Nachmittag and a representative state big band was established under the auspices of the Ministry of Propaganda. Previously, some SS music centres attempted to create 'racially correct' syncopated music as a Nazi competition for jazz, but these endeavours were unsuccessful. Cf. Will Studdert, " 'Happy Hour in the Afternoon' and 'Station Debunk': Two Nazi Jazz Projects of World War II", in: Music and Propaganda in the Short Twentieth Century, ed. Massimiliano Sala, (Turnhout: Brepols 2014), pp. 37-56. 
explained by Blessinger through a characteristic Nazi medical-biological metaphor. He claimed that the Schlagerstill works in the spiritual sphere just as drugs affect the physical one. People become addicted and demand more and more, even though the narcotics ruin their health. "This demonstrates," concludes Blessinger, "how hard it is to stop the craving for poison once it has been injected, and how hard it is to awaken the racial instinct once it has been lost." 181

The author attempts to demonstrate the truth of all Nazi theses through a tendentious choice and interpretation of historical facts, the statements of eminent composers, various episodes from their biographies, and analyses of individual works. Like the other theorists discussed above, Blessinger manipulated the choice of facts so as to prove his aprioristic initial thesis. This method, which can be called 'politically motivated deduction', can best be illustrated through the example of his treatment of quotations from, and inspirations by, the works of other composers in the music of three eminent Jewish-German artists. Blessinger quotes random examples of similarities between Mendelssohn's motifs and those of Beethoven and Zumsteeg to prove the creative impotence of the entire 'antirace. He approaches the music of Meyerbeer and Mahler in the same fashion. In order to authenticate his theses, he also quotes Wagner's and Schumann's criticism of Les Huguenots. Schumann pointed out evident influences of Rossini, Mozart, Herold, Weber, Bellini and Spohr in Meyerbeer's music. Though both Wagner and Schumann valued Mendelssohn highly, this inconvenient fact is explained so as to defend the authority of the German masters. In the historical realities of the 19th century, claims Blessinger, even a genius endowed with such racial instinct as Wagner could miss the truth that "every Jew, with no exceptions, strives to achieve the control of his race over the world." 182

There are no exceptions since a Jew who does not support this aim will be rejected by the Jewish community as a traitor, and, consequently, no one will ever hear about him, says Blessinger.

The above-presented set of theoretical concepts and types of argumentation behind musicological research is an attempt to reconstruct part of the reality of the Nazi state. The ideology-dominated scientific world produced publications which mixed no-nonsense, rational thinking with demagogy. Otherwise competent analyses sometimes led to curious conclusions and generalisation.

181 Blessinger, Judentum, p. 153: „Hier ist ein deutlicher Beweis dafür gegeben, wie schwer es ist, einen einmal festgesetzten Giftstoff wieder zu beseitigen und einen verlorengegangenen Rasseninstinkt wiederneu zu wecken“.

182 Blessinger, Judentum, p. 81. 
Objective scientific discourse appeared side by side with chauvinist exaltation and anti-Semitic hysteria. This corset of ideology inevitably meant that deduction was favoured to induction, facts were manipulated and the musical reality was tendentiously presented. For these reasons, any polemic seems pointless - especially if we were to conduct it within the scientific framework of the present-day state of knowledge and historical experience. On the other hand, however, the question appears whether we can reconstruct the intentions and motivations and separate the academic paradigms of that time from ideology and politics. This problem calls for separate research and cannot be solved within the limits of the present study. Nevertheless, a study of the abovementioned publications confirms the well-known truth that in the totalitarian state, attitudes to the official ideology vary from fanatical zeal to ostentatious reserve, even suggesting some form of opposition. Though little is known about the biographies of the authors discussed here, one can hardly overlook the diametrical difference in the research stances (and human attitudes) between Müller-Blattau and Blessinger. The former used the safe guise of nationalism to present research which - though it satisfied the official demands - could harm no one. The latter presents himself as a fanatical Nazi who actively supported the crimes of the regime. While the results of the former scholar's research still preserve their validity, Blessinger's work can now only be viewed as a terrifying example of political denunciation supported by the use of pseudoscientific discourse. However, was Blessinger really a fanatic? In his book Die musikalische Probleme der Gegenwart und ihre Lösung ${ }^{183}$ of 1919 we find none of the visions of the Jewish threat known from his Judentum und Musik. The latter text may either testify to his ideological conversion or to his political conformism.

What, then, is the contemporary value and significance of racism-inspired music-theoretical works? They are undoubtedly a document of directions in German theoretical thought at that time. Even if we modify their theoretical basis and remove the thesis concerning the inequality of races and the convictions concerning genetic determination, if we postulate that all research be purely empirical - it is still hard to imagine that a modern scholar could ask questions such as "Was ist nordisch?" with reference to form, melody and harmony. The same concerns the complex of problems related to "Judentum in Musik", though in this area the Nazi studies can at least direct our attention to the vast, not fully

183 Blessinger, Die musikalische Probleme der Gegenwart und ihre Lősung, (Stuttgart: Filser Verlag, 1919). 
recognised contribution of persons of Jewish origin to music composition, performance, pedagogy, theory, as well as the organisation of musical life in various European countries. ${ }^{184}$ The questions we ask as scholars clearly reflect the character of our own times and our specific historical reality.

184 It ought to be remembered that not all the texts on the broadly conceived "Judentum in Musik" published in the Third Reich represent the Nazi point of view. An example to the contrary is Julius Sachs's booklet Der Jüdische Musikalien - Katalog: Die wichtigsten Werke Jüdischer Komponisten (Breslau: Brandreis, 1936). Both the title and the date of publication suggest just another political denunciation. However, the book is in fact an attempt to promote (!) the compositions, music performances (piano paraphrases) and editorial activity of the German Jews: "Mit Stolz kann man auf die Künstler und ihre Werke blicken, die dieses Buch füllen" - says the author in the introduction and notes that - while scholars disagree concerning the existence of Jewish folk music - the artistic music composed by the Jews is undoubtedly "reich an Genialität." On the other hand, however, Sachs misappropriates some artists, for instance by placing Chopin in the catalogue only because his works were arranged by Friedmann (!) This kind of inadvertent errors (Chopin listed among Jewish composers) could be used by the Nazis as yet another argument to support their propaganda. 



\section{Das Volk, die Volksgemeinschaft, der Volkskomponist: The Concept of the "Community of Blood" and the Debate Concerning National-Socialist Normative Musical Aesthetics}

Was the Third Reich a totalitarian state? The question may seem absurd. And yet - as Karen Painter demonstrates - there are many historians who argue that the German nation's enormous support for Hitlerism (at least in the initial years of the Nazi rule) and the fact that the Nazis took over power in a legal way make the answer not as obvious as it might seem. ${ }^{185}$ On the other hand, Hannah Arendt in her classic monograph The Origins of Totalitarianism, claims that of all the European dictatorships that emerged in the first half of the 20th century, only two can be described as fully totalitarian: the Third Reich and Stalin's USSR ${ }^{186}$. This is because only these two empires, says Arendt, aspired to global hegemony. The compulsion to struggle for worldwide domination results from "the very nature of totalitarianism." For this very reason, Mussolini's fascist regime which is believed to have coined the term 'totalitarian state' - does not fulfil Arendt's criteria for a totalitarian state, despite the belligerent poses and cocky declarations for which the Duce was notorious.

More frequently, however, we meet with interpretations of totalitarianism which focus first and foremost on the forms of internal rule and authority in the given country ${ }^{187}$. From this point of view, totalitarian rule is undoubtedly one that strives to control every sphere of the citizens' lives, depriving them of their individual private freedom inasmuch as the technical instruments of control and the available coercive measures make it possible. It is commonly known that

185 Painter, Musical Aesthetics, p. 121. Notably, doubts concerning the totalitarian character of the Third Reich were also formulated by the German historian Martin Broszat, for whom the social-political system of the Nazi state was determined more by a rivalry between party and state bureaucrats than by Hitler's authority as a dictator.

186 Arendt, The Origins of Totalitarianism, pp. 380-392.

187 Cf. Carl Friedrich, Zbigniew Brzeziński, Totalitarian Dictatorship and Autocracy, (New York: Harvard University Press, 1961), pp. 52-54; Norman Davies, Europa. Rozprawa historyka $z$ historia [Europe. A Historian's Dispute with History], (Kraków: Znak,1999), pp. 1017-1027. 
omnipresent propaganda and ideological indoctrination, as well as the attitude of the authorities to those few who did not accept the ruling ideology - leave one with no illusions as to the character of the Nazi state, even though power was taken over quite legally and the majority of the citizens supported the regime.

What is paradoxical in this context is that in the case of the Third Reich, one may hardly speak of one official normative musical aesthetic since there were no regulations and guidelines that could establish such norms ${ }^{188}$. It is usually stressed that the Nazi state's cultural policy was inconsistent and decentralised. It depended on personal conflicts between high ranking state and party officials who competed in this field (mainly between Rosenberg and Goebbels). It was also prone to frequent changes and upheavals resulting from incongruent decisions typical of Hitler's bureaucracy and from the unclear competences of the various centres of authority. Even though negative models, mainly in the form of the so-called 'degenerate art' (Entartete Kunst) were commonly known, the regime did very little to clearly define the music of 'the national socialist era'. Goebbels's famous 'ten commandments of German music' (announced during the opening ceremony of Reichsmusiktage in 1938) consisted in fact of commonplaces and generalisations concerning links to 'the people' or 'the nation' (das Volk) and the primacy of melody and empathy over intellectual constructs ${ }^{189}$. Little was also done to censor ${ }^{190}$ music composition apart from the previously discussed assessment

188 Painter, Musical Aesthetics, pp. 121-122.

189 Joseph Goebbels, “Zehn Grundsätze deutschen Musikschaffens”, in: Amtliche Mitteilungen der Reichsmusikkammer 5, No. 11 (1938), quoted after: Albrecht Dümling, Peter Girth, (eds.). Entartete Musik: eine kommentierte Rekonstruktion, (Düsseldorf: Servicedruck Kleinherne, 1988), p. 123;. See also: David B. Dennis, Inhumanities: Nazi Interpretations of Western Culture (New York: Cambridge University Press, 2012), pp. 176-177. Some scholars believe that Goebbels' “Ten Principles" simply reflected the Propaganda Minister's own personal tastes and were symptomatic of his ignornce in serious music. See: Robert Warren Bailey, Performing for the Nazis: Foreign Musicians in Germany, 1933-1939, MA diss. University of Calgary, Alberta, 2015, pp. 9-10, https://prism.ucalgary.ca.

190 Muzyka Polska (No. 2, p. 106) informed early in 1939 that the Reichsmusikkammer established a music censorship office in order to "prevent the performance of undesirable or harmful works." From the report we learn, however, that the harmfulness was usually associated with racial origin. Cf. also: A. E. Steinweis, Art., Ideology, and Economics In Nazi Germany: The Reich Chambers of Music, Theater, and the Visual Arts, (Chapel Hill (NC): University of North Carolina Press, 1993), pp. 138-142 and Ursula Geisler, "Political Music Censorship: Some Remarks on Nazi Music Regulations 1933-1945”, Danish Musicology Online Special Edition, 2015, pp. 77- 89, http://www. danishmusicologyonline.dk. 
of the racial identity of the composers themselves. One must remember, however, that national enthusiasm and pro-state sentiments, even fanatical admiration for the ruling ideology - were very common in music circles, which made all censorship and bureaucratic limitations simply redundant, because the music environment censored itself, and music critics, musicologists as well as musicians competed in their efforts to discover and emphasise what was 'truly German' and 'racially valuable' in music. Research conducted by Karen Painter ${ }^{191}$ proves that critics belonging to the Arbeitsgemeinschaft Berliner Musikkritiker were the first to express their full support for the cultural policies of the new government - as early as the spring of 1933. Soon, leading representatives of all music-related professions expressed their enthusiasm for the Nazi 'national revival': from instrument builders to teachers to composers and performers of church music. Enthusiastic in their support of national socialism, especially in the early years of the Third Reich, was the young generation of composers who clearly believed in the same myth that lured Russian futurists about twenty years earlier - that the revolution was bound to support 'new music' (whatever this was supposed to mean); many artists secretly hoped that this would be their way to recognition and acclaim. They were fascinated with the idea of a state protecting artists and promoting their works. The young composers expected art (like the politics of the day) to encourage national unity and facilitate a new, general integration of society. The economic situation distinctly improved after 1935, which translated into a gradual decrease in the number of unemployed professional musicians. This fuelled the enthusiasm. Careerism and opportunism added to this trend. According to Michael Kater, during the 12 years of the Third Reich's existence, more than 20,000 politically motivated music compositions were written. Most of them were dedicated to the ruling ideology and to the cult of Hitler himself $f^{192}$.

This situation explains why Goebbels could afford the 'liberal' view expressed at the opening of the Reichsmusikkamer (and discussed by Otto Graf) that "the national-socialist state must uphold the principle that art is independent, and lack of intuition may by no means be replaced by organisational structures. Art may develop and flourish only in conditions of maximum possible freedom..."193

191 Painter, "Musical Aesthetics", p. 122.

192 It should be noted that the Führer, seeing how art was becoming a convenient springboard for mediocre artists' careers, forbid the dedication of new music works to him (1935). Cf. Michael H. Kater, The Twisted Muse: Musicians and Their Music in the Third Reich, (Oxford: Oxford University Press, 1997), p. 13.

193 Cf.: Otto Graf, “Organizacja życia muzycznego w Niemczech” [Organisation of Music Life in Germany], Muzyka Polska, VI, 1935, p. 114. Similarly 'liberal' views were 
It also becomes clear why - in the first years of the Nazi rule - Goebbels's Reichsmusikkammer refused to censor piano recital programmes at Berlin's concert halls so as not to permit performances of 'atonal' music, which was postulated by the influential Nazi critic Dr Fritz Stege ${ }^{194}$. The ministry's reply was unequivocal - let the audience pass judgments on the value of the music. Though such a reply was - as often indicated - supported by the authority of the then head of the Reichsmusikkammer, Richard Strauss, it is still a telling fact that the minister backed Strauss against the demands of an influential party activist ${ }^{195}$.

Naturally, from our present historical perspective and point of view it is easy to accuse the German music circles of that day of conformism, opportunism, short-sightedness, and other (even worse) vices. We should remember, however, what the economic situation was like in Germany in 1933, how long and painful the Great Depression proved to be, and what level of unemployment German musicians had to face, though most of them still remembered the halcyon days and the universal flourishing of music life in the German empire. Germany was one of the world's richest, most modern and dynamically developing countries, traditionally associated with high culture and its generous support by both the state and private patrons. In the face of the Great Depression in the late 1920s, however, this state was forced to gradually reduce its subsidies for music institutions, which - combined with the bankruptcy of many

expressed by Goebbels also much later. Stephen McClatchie quotes Goebbels' letter of 19th November 1943 to Hans Lammers, where he wrote that every act of official censorship is a threat to "the development of German culture." Cf.: Stephen McClatchie, "Wagner Research as 'Service to the People': The Richard -Wagner Forschungsstätte, 1938-1945", in: Music and Nazism: Art under Tyranny, 1933-1945, Michael H. Kater and Albrecht Riethmuller (eds), (Laaber: Laaber-Verlag, 2003), p. 160.

194 German musicians recalled that Stege was notorious for his fanaticism and for ruthlessly eliminating his aesthetic opponents. For instance, in 1934 he denounced Hans Stuckenschmidt to the authorities for his involvement in the defence of artistic freedom, new musical ideas and musicians of Jewish origin. As a result Stuckenschmidt was banned from publishing (Schreibverbot), which led him to choose emigration later. Cf.: Frank Hilberg: "Vom Protagonisten zum Anachronisten - Zu einer Textsammlung von Hans Heinz Stuckenschmidt", in: Musik Texte Nr. 134 (2012), p. 91.

195 As we know, the Nazis did not collaborate with the famous composer for too long. In 1935 the Gestapo intercepted a letter from Strauss to Stephen Zweig, in which Strauss distanced himself from racial policies and admitted that he used the post of head of the Rechsmusikkammer to play a game with the regime and prevent an even worse situation in musical life. Disgusted and indignant, Goebbels suggested dismissing Strauss, officially because of his old age and deteriorating health. 
private businesses that had previously supported culture - led to the closure of orchestras, opera houses, music schools and other similar institutions, as well as to a drastic reduction of concert life. No wonder that music circles - like workers and the intelligentsia - had little to thank the Weimar Republic for. Despite the gradual improvement of the situation in the 1930s, in 1936 about $80 \%$ of those lucky musicians who had regular employment earned c. 200 Deutschmarks per month - less than the average worker's pay. Unemployment among musicians amounted to roughly $20 \%$ - double the country's average. It was therefore life itself that made musicians - especially those playing wind instruments - enthusiastically greet the formation of the great Wehrmacht, whose different troops in fact competed for who could boast the best brass band. The same was true about paramilitary and youth organisations, each of which wanted to have its own orchestra and its own music events. No wonder, then, that the music environment supported Goebbels, who as early as 1935 launched a programme of financial assistance for unemployed, sick and retired musicians, and imposed on the immensely popular foreign bands that played Schlager und Tanzmusik a tax on their profits in the German Reich (the bands themselves decided about its level) which went toward the maintenance of unemployed German musicians ${ }^{196}$.

In 1938 the situation was already diametrically different. The economy prospered, fuelled by armaments, while the first territorial conquests provoked such an explosion of musical activity that qualified instrumentalists and singers were in short supply, which persuaded Goebbels to pass a decree guaranteeing a minimum wage in this profession. Moreover, orchestras classified as 'high culture' were granted higher fees than dance-and-entertainment bands. It was then that orchestras were divided into five classes, and the musicians' pay depended on the artistic competences of the given orchestra.

Let us now return to the beginnings of Nazi rule and the high expectations of young composers, and in fact nearly the entire music world in Germany. Those expectations were aroused by an official statement from Walther Funk, secretary of state at the Ministry of Public Enlightenment and Propaganda (Reichsministerium für Volksaufklärung und Propaganda), who represented the state authorities during the general assembly of the German Composers' Union

196 Detailed statistical data concerning the improvement of the situation of German musicians, a higher level of employment, and growing number of orchestras and music theatres in Germany in 1931-1936 were published in "Muzyka Polska" in January 1936: anon. "Kronika: Niemcy - Nowe hasła" [The Chronicle - Germany - The New Slogans], Muzyka Polska, Jan. 1936, pp. 83-84. See also: Kater, The Twisted Muse, pp. $7-11$. 
(Berufstand Deutscher Komponisten) held in Berlin on 16th-20th February 1934 and chaired - as the Polish press emphasised - by Richard Strauss himself ${ }^{197}$. The event was organised on a grand scale, with fine music performances (including a concert of the Berliner Philharmoniker under Wilhelm Furtwängler) and international publicity. Representatives of composers' associations from several European states were invited to deliver speeches, and the sessions of the assembly were attended by numerous journalists, representatives of the diplomatic corps, and all major figures of German music life in that period, including Richard Strauss, Paul Hindemith, Hans Pfizner, and Otto Schumann. Sweden and other Scandinavian countries (warmly referred to by the German press as 'the Nordic community') were represented by the then leading Swedish composer of national orientation, Kurt Atterberg, who was also a music critic. Carol Bérard, vicepresident of the French Composers' Federation, spoke on behalf of his country; Italy was represented by Adriano Lualdi, Austria - by Wilhelm Kienzl, who - to the delight of the hosts - stressed the importance of the "German blood brotherhood"198. Most frequently commented upon by both the German and foreign presses were two speeches. One was given by Richard Strauss, Germany's highest, widely accepted authority on musical matters and the unquestioned leader of the German composers' milieu; the other - by Walther Funk, whose statement was greeted as the initial declaration of the new German authorities concerning the centralisation of German music life and the key points of the government's cultural policy. It was also from Funk's speech that composers could learn - in general terms - what the new authorities expectations from them were. I will discuss his line of argument here.

Every 'true art', claimed Funk, derives from the nation, the people (das Volk). The aim of the new government is to restore the right order of things, in which artistic activity is a concern of the entire nation. The times of 'uncontrolled liberalism' under the Weimar Republic led to a total alienation of artists; the nation began to shun contemporary music. At the same time, liberalism and its key tenet - 'unbridled individualism' - caused egoism on a massive scale and the disintegration of the national community. It was liberalism that laid the foundation for ultra-modernist tendencies in art, which proved fatal, as they created a gap

197 Cf. Anon. “Kronika”, Muzyka, No. 3 (113) 1934, p. 136.

198 Cf.: Petra Garberding, "'We Take Care of the Artist': The German Composers' Meeting in Berlin, 1934” Music \& Politics 3, No. 2 (Summer 2009), https://quod.lib.umich. $\mathrm{edu} / \mathrm{m} / \mathrm{mp} / 9460447.0003 .204 /$--we-take-care-of-the-artist-the-german-composersmeeting? rgn=main;view=fulltext, accessed: 20.06 .2014 . 
between artists and the nation. The same ideology also contributed to the economic crisis, which placed the artists representing high culture in a catastrophic situation. In the modern world, Funk argued, there are no patrons of art, so the government must extend its protection over art and artists ${ }^{199}$.

Here, naturally, one must ask whether the work of every ('racially impeccable', of course ${ }^{200}$ ) German composer will be the subject of such state patronage? In this case, the German press reports interpret Funk's speech in rather different ways. Fritz Stege, already mentioned above as the leader of Berlin's music critics, summarised the gist of Funk's speech briefly as follows: "The main point is not the direction, but the essence of art. The nation (das Volk) will again live in and with art, and artists will be welcomed again by the nation! This is the first task of national-socialist cultural policy with regard to artistic work." ${ }^{201}$ Robert Oboussier presented Funk's views in more detail: "The task of [German] art is to express the essence of German-ness (die deutsche Wesenart). The nation may live in art and with art only when this art grows out of national roots. If these conditions are fulfilled, the state is ready to accept responsibility for artistic patronage." 202

Of crucial importance here seems to be the meaning of the term das Volk and its semantic evolution in the Nazi period. As correctly observed by Petra Garberding ${ }^{203}$, to the German-speaking observers of the Berlin assembly of composers, this term was associated with 'the nation' or 'the folk', which fitted in with the (more or less modernised) trend of 'return to the roots' strongly present in many European countries at that time, for instance in the works of

199 Based on the report of Kurt Atterberg, quoted after: Garberding, "We Take Care of the Artist", pp. 6-7.

200 Giselher Schubert, “The Aesthetic Premises of a Nazi Conception of Music," trans. Steven Lindberg and Joan Evans, in Music and Nazism: Art Under Tyranny, 19331945, eds. Michael H. Kater and Albrecht Riethmüller (Laaber: Laaber-Verlag, 2003). According to Schubert's correct observation the substance of the National Socialist aesthetics of music was mainly racist and political. pp. 64-65.

201 Fritz Stege, "Der Deutsche Komponistentag”, Der Berliner Westen, 19 Febr. 1934: "Es geht nicht um die Richtung der Kunst, sondernd um die Art der Kunst. Das Volk soll wieder in der Kunst und der Kunstler im Volke leben! Das is die erste Aufgabe drer nationalsozialistischen Kunstpolitik". Quote after: Garberding, "We Take Care of the Artist", p. 8.

202 Robert Oboussier, "Der schaffende Musiker in neuen Deutschland. Erster deutscher Komponistentag”, Deutsche Allgemeine Zeitung, 19 Febr. 1934, quote after Garberding, "We take Care of the Artist". p. 7.

203 Garberding, "We Take Care of the Artist", pp. 7-8. 
Bartók, Szymanowski, Respighi, Vaughan Williams, and others. By examining the semantic contexts of the Swedish translation in Atterberg's press reports for the Stockholm press in that period, the Swedish scholar demonstrated that he understood this term in a highly 'conservative' way. For the Nazis, however, das Volk was not merely a group of people united by one language and culture. It was now, first and foremost, a racial-biological community, a "community of blood".

The world learned more about this "community" in the context of the Nazis' musical-aesthetic demands in 1938 from the previously mentioned article by Fritz Stege ${ }^{204}$ in the Brussels-based international magazine La Revue Internationale de Musique. Stege wrote that three ideas: those of the nation, the state, and art must become one. This is necessary because the state is unimaginable without its nation, and the nation - without its own art. Art, on the other hand, cannot exist 'for its own sake' without the honour of expressing the nation's ideas. Should the Germans continue in that direction which developed after the Great War, the German audience would lose all contact with contemporary music and concert halls would be quite empty. Composers would have no other audience but themselves. The author proudly affirms that now, German composers no longer act on behalf of any "narrow group of snobs" but attempt to express the spiritual aspirations of the entire Volksgemeinschaft. The same Volksseele, he claims, was expressed in the past by such masters as Mozart, Beethoven, Schubert, and Brahms. Each of them represented the spirit of the community and deserved to be called a Volkskomponist (here this mythic term again) regardless of whether their works were actually based on German folklore. As we can glean from this statement, a Volkskomponist can express the spirit of the national community and inspire it to follow him, and can create works both original and comprehensible for that community. This is the creative stance that Germany expects from its composers. Naturally, in order to deepen the national community's perception, the state ought to conduct large-scale and comprehensive activity in the field of the society's music education. The level of that education must be more or less equal so that the 'musical Volksgemeinschaft' becomes a fact. Additionally, classes previously deprived of access to German 'high music' will in this process come to accept it as their own, because it has grown from the very centre of the nation's soul. The immensity and scale of this project is evident in the list of educational-popularising actions carried out in this area: symphonic concerts in factories and small towns far away from large cultural centres, etc.

204 Fritz Stege, “Die gegenwartige Lage der deutschen Musik”, La Revue Internationale de Musique, 1/1, March-Apr. 1938, pp. 77-84. 
The social dimension of music in the German Volksgemeinschaft was described in a somewhat broader historical perspective (most likely expressing the views of NSDAP's left wing, which is evident in the strongly anti-bourgeois rhetoric) in an extensive study written for the Polish audience by Otto Graf, who wrote in 1935:

"For Germans, the Great War marks the boundary between 19th-century culture and the cultural needs of modern Germany. Before the war the bourgeoisie, made barren by prosperity, opposed the working class which fought for its right to survive. Today our nation is united in the experience of shared calamity. The traditional foundations of culture are questioned and collapse, while the material wealth of the nation and its ideological foundations - individualism and class consciousness - disappear. We must become aware of two indispensable foundations of culture - race and blood - and the fact that even the greatest genius is nothing if he does not form a close bond with the blood of the nation."205

Graf stressed that striving for the optimal development of the creative individual is no longer the most vital aspect of culture, and the artist should not aim exclusively at expressing his or her 'inner self'. The artist may not act in isolation from the needs of the nation and ought to consider the nation as "principal and patron, inspiring him to create." Graf postulates "looking for points of convergence in those instances when pure culture grew exclusively out of the life of the people." He claims that this was the situation from the 16th to the 18th centuries, when "music was folk music in the most proper sense of the world." This is why, Graf claims, we now "sense the close bond between the art of that time and the yearnings and desires that still motivate us today." Apparently afraid that he might be misunderstood (because the Polish audience will read him in translation without access to the original), Graf explains that he certainly does not call for halting progress in music; it is only necessary to prevent extreme and unbridled trends. He also expresses his support for ambitious functional (utilitarian) musical forms and highly praises the earlier achievements of Paul Hindemith in this area, claiming that his works will be "the lodestar for the music of the future" because they were a reaction against "the stifling and hypocritical music from previous decades..."206 The most important imperative, however, for an artist in contemporary Germany must always be "the sense of responsibility for educating the nation." Mass and modern music education therefore becomes a priority.

205 Graf, “Organizacja życia muzycznego”, p. 121.

206 Graf, “Organizacja życia muzycznego”, p. 125. 
The immense importance of occasional and functional music in the social life of Germany and the generous state support for such music were also the subject of a report from an anonymous correspondent of "Muzyka Polska", who informed Polish readers in 1936 about the methodical and premeditated "incorporation of music into the life of the nation, and turning music into a living form of applied art, a necessary component of Germany's collective national life."207 The correspondent stressed that such music must be adjusted to the community, to the wide social masses in Germany - and must appeal to those masses:

"Hence the slogan: folk song and folk music, that is, the one that originated in the folk now or in the past, and that is comprehensible for this folk. [...] The state frequently entrusts the writing of such music to individual composers. They still get lots of experimentation and have not created a uniform style yet, because the movement is too young for that. But its value lies in its very existence..." 208

It isn't difficult to see the similarity between the emphasis on universal communicative qualities and the related official state-inspired postulate of simplifying musical style - and the principles formulated about a dozen years later by socialist realism. The national-socialist propaganda of 'universal accessibility' anticipated to a very large extent the rhetoric of socialist realism from its most coarse period. In both cases one must distinguish the postulate of 'return to simplicity' by itself from the forms of administrative-political pressure that forced artists to implement this postulate.

One should remember that in the 1930s the music environment in many countries of Europe was evidently tired of the avant-garde sometimes referred to as 'ultra-modernism' and associated in popular thinking with dodecaphony, which - in the view of many critics and composers - 'undermined' the foundations of European musical culture. An alternative was seen in Emmanuel and Ravel's neo-modality (praised in 1937 by the Paris-based Dutch critic Fred Goldbeck ${ }^{209}$ ), while others saw a chance for rescue and revival in vitalism, neoClassicism or in the influence of jazz. It must be clearly stated that the very tendency to simplify technical principles is by no means 'backward' or reprehensible and has appeared many times in the history of art, for instance in the form of the classicist reaction to the exuberance of the Baroque. Moreover, the

207 Anon. "Kronika: Niemcy - Nowe hasła" [The Chronicle - Germany - The New Slogans], Muzyka Polska, I 1936, p. 80.

208 Anon. "Kronika”, pp. 80-81.

209 Fred Goldbeck, "La musique dans l'exposition internationale de 1937”, Numero special de la Revue Musicale, 1937, pp. 85-91. 
simplification of technique - even when it evidently took place under pressure did not prevent great individuals from producing outstanding works of art. Such compositions as Lutosławski's Concerto for Orchestra, Orff's Carmina Burana, numerous pieces by Myaskovsky, Shostakovich and Prokofiev prove that on a certain level of artistic mastery, simplification - even that more or less imposed on artists - did not affect the originality of their works. The relevance of the rhetoric that demands 'creative freedom' may also be questioned by demonstrating that it does not have a strong historical basis. What kind of 'creative freedom' was enjoyed by such artists as Bach, Haydn, and Mozart, not to mention a whole galaxy of earlier masters who left behind epoch-making masterpieces? On the other hand one should remember that the historical transformations of the 19th century extended the autonomy of art to previously unknown dimensions, making this creative freedom - like other civil rights - part of the civilizational canon of modernity, protected by the powerful world of the media, the most influential of which in the early 20th century was the press.

And it was the press - primarily the British press - that immediately pointed out to Fritz Stege that what he described as priorities of the state's cultural policy became in fact a form of pressure that clearly infringed upon creative freedom. Furthermore, English commentators were aware of just how greatly the attitudes of the Nazi state contrasted in this respect with the openly liberal approach of the fascist authorities in Italy, which made a point of opening up to all creative trends. Considering Hitler's great esteem for Mussolini as the pioneer figure of the 'new order' in Europe and the substantial propagandist benefits from such cultural policies as those adopted by Mussolini - why did the Third Reich opt for a different approach? Even if this new approach was not regulated by any official orders and remained mostly in the sphere of 'recommendations'? Paradoxically, however it was understood and implemented, the limitations of pluralism in artistic life could only turn against the propagandist interests of the very state that imposed such limitations. It seems obvious that in the best interest of every state, it should aim to achieve global renown for as many artists working under its patronage as possible, which translates into positive reception of the country in the media - regardless of what aesthetic forms the authorities themselves may prefer. Mussolini was certainly aware of this propagandist advantage (I will elaborate on this subject further on). Many years later this mechanism was also understood by the authorities of communist Poland under First Party Secretary Władysław Gomulka, which viewed the avant-garde with a kind eye even though one can hardly suspect them of authentic admiration e.g. for Penderecki's sonorism. But - as those old enough may still recall - the international success of any Polish citizen was automatically advertised as a success of 
the socialist state (while a Polish citizen's failure was naturally his or her own private affair...) Why, then, was this mechanism not comprehended by the German minister of propaganda?

It seems that opinions expressed in the Western press made little impression on the German authorities of the time. One should also remember that Germany - as the country that produced the most modern cars, locomotives and aeroplanes - had no complex of 'civilizational backwardness' that would need to be compensated by some kind of 'modernity' in art. The aforementioned condemnation of the musical avant-garde as a conspiracy of the 'anti-race' aiming to destroy the order and harmony of the Aryan culture - definitely excluded any other stance but that presented by Funk, Stege and Graf. In 1933-1936 the obvious political priority was national integration - possibly as thorough as possible - and the Nazis subordinated all their actions to this aim. The task of winning over the hearts and minds ${ }^{210}$ of as many Germans as possible - especially from among the working class - was much more important that the opinions of the international press. Artistic taste is an indicator of social status, claimed the French sociologist and philosopher Pierre Bourdieux many years later. Making the world of elitist music available to the average German ${ }^{211}$ (who had previously not been able to afford it, in financial terms) and the authority's declaration that - regardless of social position - the average German, as part of the mythic Volksgemeinschaft, is the subject and the main addressee of new music ${ }^{212}$; excellent orchestras performing in front of working-class or small town audiences, which may not have fully understood the masterpieces it heard, but did certainly

210 This was clearly stressed by Goebbels in his speeches. For instance, at the 1934 Parteitag in Nuremberg he said that for what is important for maintaining authority is not brute force but "winning over the heart of the nation, and not letting it go" (das Herz eines Volkes zu gewinnen und es auch zu behalten). Quoted after: Bernd Sponheuer, "Nationalsozialismus", in: Musik In Geschichte und Gegenwart, 2003, Sachteil, Vol. VII, p. 26.

211 As early as 1934, Goebbels stated emphatically that from that moment on every German, regardless of social class, will have access to the opera and to other forms of high musical culture, previously reserved for the financially privileged strata. This gesture was praised by some British commentators. Cf.: Eric Levi, "Appeasing Hitler? Anglo-German Music Relations, 1933-1939”, in: Music and Propaganda In the Short 20th Century, Massimiliano Sala (ed.), (Turnhout: Brepols, 2014), p. 27.

212 In a speech delivered at Berlin Opera on 26th November 1937, Goebbels stressed that people look to the theatre and the concert hall for what they are missing in their everyday lives: namely - beauty, nobility, wonder and illusion. Quoted after Sponheuer, "Nationalsozialismus", p. 27. 
appreciate the gesture itself - all this was a masterstroke of social engineering and propaganda ${ }^{213}$. These gestures were meant to emphasise the 'socialist' programme of the new authorities, which aimed to give everyone equal opportunities and to create conditions for the social-cultural advancement of the very same classes that had traditionally been defended by the left wing. In this way the Nazis deprived the left - gradually pushed to the margin, and soon silenced by arrests - of its chief weapon, winning over the simple folk mostly because all the above-listed gestures were made to look genuine by the improved economic situation and the quickly falling levels of unemployment.

The cultural policy and all levels of social activity were no doubt dominated by paramount purpose of the nation's total integration around Nazi ideology and around Hitler himself, whose rapidly developing cult inevitably led to the acceptance of the Führer's tastes and preferences as a model of 'political-aesthetic correctness' for the entire state. As we know, apart from Wagner, Hitler was particularly fascinated by Bruckner and Beethoven, but historians stress that Hitler himself did not interfere with current developments in music composition, nor was he really interested in them in fact, ${ }^{214}$ since he focused on architecture (which resulted in his famous collaboration with Albert Speer ${ }^{215}$. On top of this, the Germans were, as I already mentioned, universally aware of the greatness of their own music tradition, and so the regime was interested in the appropriating and propagandist use of that tradition rather than in focusing on new music ${ }^{216}$. The

213 We may note a certain analogy to the new type of 'egalitarian' relation between officers and low-ranking soldiers, as described by the US correspondent in Berlin William L. Shirer. From the moment the Wehrmacht was formed, the old divisions of class and caste were abolished in favour of a protective attitude on the part of the officers, so that soldiers would feel they are the subjects, not objects, in the military structures. Cf.: William L. Shirer, Dziennik berlinski [The Berlin Diary, originally published: New York: Alfred A. Knopf, 1941], transl. J. Kudliński, (Warsaw: Bellona, 2007), pp. 328-329.

214 More on the musical interests of the dictator of the Third Reich in reports of eyewitnesses in: Christa Schroeder, Bytam sekretarka Hitlera [I Was Hitler's Secretary], transl. M. Podwysocka, Warsaw: Bellona, 1999, pp. 170-171, English edition: He Was My Chief: The Memoirs of Adolf Hitler's Secretary, Engl. transl. Geoffrey Brooks, (Barnsley, Yorkshire: Frontline Beeks, 2012).

215 Cf. Painter, Musical Aesthetics, p. 123

216 More on political manipulation by means of national-musical myths in: Iwona Massaka, Muzyka jako instrument wplywu politycznego [Music as an Instrument of Political Influence], (Łódź: Ibidem, 2009), pp. 204-207. See also: Bernd Sponheuer, "The National Socialist Discussion on the 'German Quality' in Music," in Music 
traditional cult of the so-called absolute music in Germany and the fact that the leading Nazi musicologists rejected illustrative and programmatic music as alien to the German spirit (Blessinger) made it inevitably difficult to precisely define those musical categories that were supposed to embody the spirit of national socialism. Stege, for whom (apart from obvious racial criteria and the equally obvious distancing himself from all 'racially suspect' experiments) the quality of the music was of paramount importance, saw the continuation of the tradition of great German masters as the criterion of musical quality. He saw this tradition in a rather non-historical perspective as an expression of 'the soul of the nation'. In 1936 this leading Nazi critic made it clear in his article for "Voelkische Musikerziehung" ${ }^{217}$ that the composer's party membership or declared wish to create a composition in the national-socialist spirit do not prove by themselves that the resulting music fulfils this aim. On the other hand, an apolitical composer may write music that reflects the spirit of the new time. A symphony - which as 'absolute music' seems to have no obvious relation to National Socialism - may in some circumstances prove more National-Socialist than another work which represents a superficial attempt to represent this ideology. The necessary condition is for the composer's state of mind, emotions and experiences (which inspire the act of creation to agree with Nazi principles).

This requirement is vague and imprecise at best, which makes the author's intentions quite clear. The impossibility to verify the circumstances of the creative act leaves only one way of proving the 'Nazi spirit' of the composition - the reception of the work by the wide national community, and especially - by its leaders, the Nazi officials. The complex ritual of state and party ceremonies on various levels called for suitable up-to-date, serious and monumental music that could command the respect of the audience and integrate the wide German audience. The safest way to achieve such qualities was to imitate - as closely as possible - the traditional models set forth by Beethoven ${ }^{218}$, Brahms, Bruckner and Wagner. Thus the dominant (albeit officially not specifically announced) interest of musical aesthetics in the Third Reich was a kind of academism which favoured an eclectic turn toward the national masters of the past as brilliant exponents of

and Nazism: Art Under Tyranny, 1933-1945, eds. Michael H. Kater and Albrecht Riethmüller (Laaber: Laaber-Verlag, 2003), pp. 32-42.

217 Fritz Stege, a statement in: Volkische Musikerziehung. III, 1936, p. 91, quoted after: Josef Wulf, Musik im Dritten Reich: Eine Dokumentation, (Frankfurt am Main: Ullstein Verlag, 1983), p. 247, see also: Painter, "Musical Aesthetics”, p. 127.

218 Cf. David B. Dennis, Beethoven in German Politics, 1870-1989 (New Haven and London: Yale University Press, 1996). 
the mythic supra-historical German Volksseele. This turn focused on the monumental symphonic and large-scale vocal-instrumental forms worthy of the Reich's splendour and once cultivated by the German masters ${ }^{219}$. Extremely characteristic in this respect was using the model of Brahms's Ein deutsches Requiem with new secular texts glorifying heroes who perished fighting for the Reich, while the traditional references to the Protestant chorales, Bach and Schütz were preserved. Brahms's masterpiece had already been reinterpreted in a nationalistic vein soon after the reunification of Germany, while early in the 20th century this type of interpretation was attempted by, among others, Max Reger and Hans Pfitzner. Examples of this quasi-religious tendency in the academicconservative trend of officially approved music in the Third Reich can be found in two compositions of the same title: the Deutsches Heldenrequiem by Gottfried Müller and by Hermann Erdlen, as well as the Totenfeier by Cesar Bresgen ${ }^{220}$. For obvious reasons, the heroic-national themes returned with double force when Germany began to pay with blood for their aggressive policies.

A different type of inspiration which could potentially lead to the creation of a new National-Socialist style - came from the previously mentioned consideration of 'was ist Deutsch' and 'was ist Nordisch' in music. This longing for a 'pure Nordic' racial ideal in music was clearly reflected in the early years of the Third Reich in the music critics' largely favourable attitude toward pan-Nordic ideas and the work of Jon Leifs - an Icelandic composer residing in Germany. Leifs claimed that Iceland, thanks to its complete isolation, was the only country that preserved the original uncontaminated Nordic qualities. In the context of ideologically motivated research into 'racial qualities', this sounded like a genuine revelation. On the wave of official favour and promoting his thesis about the 'racial supremacy' of Icelanders, Leifs successfully published in Germany his

219 See Karen Painter, Symphonic Aspirations: German Music and Politics, 1900-1945 (Cambridge, MA: Harvard University Press, 2007), pp. 212-18. Painter focuses on politically and ideologically biased way of reception of the great heritage of German symphonic music and the role of professional music criticism in the dissemination of specific ideologies among German audiences.

220 Cf.: Katherine FitzGibbon, Deutsches Heldenrequiem: Secular Requiem In the Third Reich as an Extension of German Tradition, a paper delivered at the international conference State Music and Dictatorship, Paris, EHESS, 14th-16th May 2009; cf. also: eadem, "Gottfiried Mullers Deutsches Heldenrequiem (1934): Nazi Ideology Cloaked in Historic Style", in: Composing for the State. Music in Twentieth-Century Dictatorships, E. Buch, I. C. Zubillaga, M. D. Silva (eds), Abington 2016, pp. 70-82. 
own settings of Icelandic folksongs and other compositions based on Icelandic folklore ${ }^{221}$.

Stege personally shared Leifs's enthusiasm about the search for the 'Nordic roots' of German culture (which he actually demonstrated in his compositions of that time, whose titles advertised them as 'Nordisch', 'Volks-', 'Deutsch', etc.). He therefore followed the work of the Icelandic citizen with much hope ${ }^{222}$.This affair, however, came to an end with a major scandal - disastrous for the idea and for Leifs's career in the Third Reich, but very fortunate for his later postwar life. In March 1941 at the Berlin Singakademie Leifs presented his Concerto for organ and orchestra, which, though motivically rooted in 'racially pure' Icelandic music, was so saturated with brutally dissonant and highly 'modernist' harmonies, utterly at odds with the Nazi model of racial correctness - that the fanatical critic had no choice but to condemn Leifs, which marked the definitive end of his German career ${ }^{223}$.

221 According to a report by Nancy Fleetwood ofromAugust 1935, a 'Nordische Abend' was held in Berlin in the summer of that year. The Berliner Philharmoniker under Hermann Stange played, among others, Jon Leifs's Iceland Overture and Sibelius's Symphony No. 5. Cf.: Nancy Fleetwood, "Musical Notes from Abroad:Germany" The Musical Times Vol. 76, No 110, Aug. 1935, p. 749.

222 Already in 1933, in the context of debates concerning the staging of Leoš Janáček’s Jenúfa in German opera houses, Stege argued that German operas ought to promote Nordic composers rather than Slavs or Hungarians. Cf.: Fritz Stege, "Die Reinigung des deutschen Opernspielplans”, Zeitschrift fur Musik, Jahrgang 100 (1933). pp. 487-488.

223 Stege was in this case supported by the audience, which ostentatiously left the concert hall during the performance of the piece. Leifs wrote his Organ Concerto for about 13 years (between 1917 and 1930). It represents his mature style based mainly on a synthesis of Icelandic folk motifs with elements of medieval technique (parallel forths and fifths) and parallel chords that sometimes led to bold, massive accumulations of dissonances. Extremely characteristic is the opening of the Concerto - aggressive organ 'clusters' set against powerful timpani strokes and chordal shifts in the orchestral part. It is hard to understand Leifs's decision to perform this piece at that particular place and time. Having lived for many years in Germany, he must have known what the authorities and the audience expected him to produce, and his position in the Third Reich was rather precarious since his wife was a German Jew. He used his personal connections to guarantee himself and his family a safe departure from Germany in 1943. Cf.: Hallgrimur Helgason, Jon Leifs, MGG, 2003, Vol. 10, pp. 1523-1524; see also: Hallgrimur Helgason, "Der islandische Komponist Jon Leifs und seine Idee der Nationalen Schule”, in: Broschure der Freiherr vom Stein-Stiftung, Hamburg 1980, pp. 17-32. 
But austerity, simplicity, even brutality was no obstacle in gaining the favour of high authorities as long as the music met with an enthusiastic reception of the wide masses. Moreover, despite the undoubtedly influential position of Fritz Stege and Alfred Rosenberg (who supported the critic) ${ }^{224}$, they did not make key decisions concerning the state's cultural policies and did not have the last word on the shape of national-socialist music. The real power and decisive voice in this area belonged to Goebbels, who had a part of the state's apparatus at his disposal, as well as a strong position in the Nazi party. It was Goebbels who decided to back the highly promising Carl Orff as the future pillar of Nazi musical culture, motivated by the enormous success of that Bavarian composer's magnum opus the stage cantata Carmina Burana.

All the same, the composer's road to the winning the favours of the Nazi propaganda minister was rather sinuous ${ }^{225}$ and led through stormy debates on a topic apparently rather far removed from the ideas of German music in those times namely, the music of Stravinsky. In a postwar interview, when asked what music was expected from German composers by the authorities in the Third Reich, Gottfried von Einem answered: "as different from Schönberg as possible." ${ }^{226}$ In the interwar period, Stravinsky's works were frequently considered as the precise opposite of Schönberg, which also coincided with the considerable success of his music in Germany. This did not change when the Nazis came to power. A large proportion of music circles as well as a wide audience held the Russian master in high esteem, while among officials and party leaders opinions were divided ${ }^{227}$. The premiere of Carmina Burana in Frankfurt am Main (1937) met with a mixed reception. Some critics felt outraged at the frivolous sections of the cantata which did not fit in with Nazi moral stance; other were not happy about the

224 As the 1930s were wearing on Stege - evidently aware of who held the real authority over culture in the Third Reich - distanced himself more and more from Rosenberg, until he finally he became Goebbels's loyal henchman.

225 Cf. Kater, "Carl Orff in Dritten Reich", Vierteljahrshefte für Zeitgeschichte, 43, 1 (January 1995), pp. 1-35, ifz-muenchen.de.

226 Kater, The Twisted Muse, p. 177. Paradoxically, Schönberg's statements from the 1930s prove his extreme nationalistic views. He stressed that his music derived from the German tradition and was free of any alien influences. He also claimed that his music could effectively thwart the hegemonic expansion of Romance and Slavic cultures. Cf.: A. Schönberg Nationale Musik, (1931): English reprint as.: National Music, in: idem: Style and Idea, L. Stein (ed.), Los Angeles: University of California Press, 1984 pp. 169-174.

227 Joan Evans, "Stravinsky's Music in Hitler's Germany," "Journal of the American Musicological Society" No. 56, 2003, pp. 525-594. 
use of Latin rather than German ${ }^{228}$. On the other hand, references to Bavarian folklore were noticed as a definite asset of the work, and the scandalising praise of the 'seven cardinal sins' might well correspond with the rise of neo-paganism, which emerged triumphant in the years when the Third Reich was at the height of its power. The cantata also anticipated the mood of 'enjoying life while it lasts', the hectic pursuit of pleasure by soldiers aware of how precarious their life was on the front. But the most significant attack came from Fritz Stege's protégé, the Nazi reviewer of the influential Volkischer Beobachter - Herbert Gerigt, and from Heinz Fuhrmann of Niedersächsische Tageszeitung, in their reviews from 15th and 16th June 1937, both critics accused Orff of an ill-fated turn to primitivism, fatalism, and pointed out the distinct influence of Stravinsky's rhythmic concepts $^{229}$.

228 Already after the war, Orff used this argument himself to authenticate the thesis concerning his supposedly critical attitude toward the regime. Cf. Michael H. Kater, Composers of the Nazi Era - Eight Portraits, Oxford University Press, 2000, p. 112. In the chapter entitled Carl Orff: Man of Legend (pp. 111 - 143) Kater summarises the postwar debate about Orff's past, quoting, among others, various highly regarded German musicologists (including Carl Dahlhaus), who resolutely rejected any attempts to accuse the composer of conformism. On the other hand, Kater underlines the very telling fact that Orff accepted the commission for music for $A$ Midsummer Night's Dream which - owing to the Nazi policy of Aryanising concert programmes - was to replace Mendelssohn's masterpiece on German concert stages. Other composers such as R. Strauss and Pfitzner distanced themselves from these kind of commissions. Though it would be hard to demonstrate that Orff shared the Nazi ideology, the data collected by Kater undermine the theses of apologists who defended the Bavarian composer. See also: Richard Taruskin, "Can We Give Poor Orff a Pass at Last?", in: Taruskin, The Danger of Music and Other Anti-Utopian Essays, (Los Angeles: University of California Press, 2009), pp. 161-167.

229 Herbert Gerigk, "Problematisches Opernwerk auf dem Tonkünstlerfest:,,Carmina Burana" von Carl Orff," in Völkische Beobachter (Berliner Ausgabe), Nr. 167, 16 June 1937, p. 5, Heinz Fuhrmann, "Zum Tonkünstlerfest 1937 des Allgemeinen Deutschen Musikvereins in Frankfurt a.M. und Darmstadt," Niedersächsische Tageszeitung (Hannover), Nr. 136, 15 June 1937. Quoted after: Andrew S. Kohler " 'Grey C', Acceptable": Carl Orff's Professional and Artistic Responses to the Third Reich, PhD diss., University of Michigan 2015, pp. 157-158, http://deepblue.lib.umich. edu/bitstream/2027.42/111359/1/askohler. Accessed: 30 .08.2018, see also: David B. Dennis, War on Modern Music and Music in Modern War: Voelkischer Beobachter Reception of 20th Century Composers (Chicago: Loyola University, 2010), p. 7. https:// ecommons.luc.edu/history_facpubs/28/ accessed: 10.11.2018. 
This was hardly a recommendation. While Orff's evident indebtedness to Stravinsky was not problematic for the audience and the performers, it was viewed as an ideological dissonance by state officials and by the critics belonging to the NSDAP. When a year later the much discussed exhibition of 'degenerate music' opened in Düsseldorf, Stravinsky was one of the targets of ideological attack. His portrait was exhibited with the following note: "Judge for yourselves whether Stravinsky is not a Jew."230 But the level of this exhibition was so low that even German music circles, known for their loyalty and support for the state authorities, could hardly conceal their disgust ${ }^{231}$. Peter Raabe, Strauss's successor as head of the Rechsmusikkamer, protested strongly, and Strauss himself quite clearly criticised the exhibition - albeit in a very diplomatic form. Eminent musicians simply boycotted this event.

Seeing that he had taken things too far, Goebbels soon closed the exhibition. The successive performances of Orff's cantata in 1938 brought him such enormous success that one could hardly pretend to ignore it. Eventually Goebbels passed a highly positive judgment on Orff's composition, praising its "splendid beauty" and the composer's "highly promising talent."232 Such words, coming as they did from an omnipotent Nazi minister, put an end to all discussions, and from 1939 onward Orff experienced his 'golden days': commissions, performances, high earnings, and most of all - the minister's favours, which was reflected in the (obviously centrally controlled) positive opinions of the German press.

It is hard to say to what extent political pragmatism proved more important here than ideological correctness. On the other hand, from the purely ideological point of view Carmina Burana_was not as problematic as the fundamentalists from Rosenberg's circles might see it. Austerity and simplicity bordering on primitivism, as well as brute force of sound were, after all, aesthetic qualities

230 Cf. Ludwik Erhardt, Igor Strawiński, (Warszawa: PIW, 1978), p. 268. According to Joan Evans this question was retained in Stravinsky's memory as a "more straightforward version of the racial slur" in the original caption under the portrait which asked "Who invented the story that Stravinsky comes from the Russian nobility?" (Evans, "Stravinsky's music" p. 570). Evans reconstructs the story of Stravinsky's formal complaint which he submitted to German authorities (Evans, "Stravinsky's Music", pp. 569-577).

231 Chracteristic is the ironic comment in the annoucement of this infamous exhibition in "Muzyka Polska" suggesting that it is the "German press" - not musicians - who decide about which works are "degenerate", Cf. "Kronika - Niemcy" [ChronicleGermany], Muzyka Polska No 5, 1938, p. 249.

232 Kater, Composers..., p. 132. 
that fitted in very well with the Nazi cult of power, contempt for all decadence and refinement, as well as the declared return to the pagan roots ${ }^{233}$. Stravinsky's music may not have been a well-received model of composition technique, but one could hardly fail to notice that it was Stravinsky who opposed Schönberg and, though considered a modernist, was never proven to be a Jew. He was a kind of 'lesser evil', and the spontaneous reaction of the German audience was a key argument for the ideologists, especially in the light of the doctrine of the German Volksgemeinschaft's infallible 'racial instinct'.

Research carried out by Michael Kater ${ }^{234}$ has revealed documents which prove that Goebbels intended to use the trend represented by Orff as a model for the future of national-socialist music. Discouraged by the eclecticism, derivative and conservative character of German music in that period, Goebbels clearly meant to use his influence to create a kind of Nazi 'modernism'. However, these ambitious plans were put off until later and eventually thwarted by the fall of the Third Reich. One could argue that the omnipotent Nazi official and the all-powerful Nazi state experienced the truth of the opening and closing motto of that very same musical work which they greeted as the correct response to its official stylistic norms: "Fortune is fickle."

233 On the other hand, as Andrew S. Kohler aptly observes, there are many dark moments in Carmina Burana: "In the context of totalitarianism, it is not surprising that Orff's works contain many sardonic, ironic, and grotesque elements, similar to what Dmitri Shostakovich was writing in the context of Soviet Russia at the same time", Kohler “'Grey C', Acceptable”, p. 133.

234 Kater, Twisted Muse., pp. 45-46. 


\section{Between Thought and Action: Nazi Racial Doctrines and the Consequences of Their Implementation in the Context of the Reactions of Europe's Music Circles in the 1930s}

Racism as the foundation of academic doctrine and thought on music and as the ideological basis of Nazi cultural policies must certainly have had an impact on the situation in other European countries in the 1930s. The reactions and their emotional colouring were greatly varied, depending on the political-ideological profile of the given magazine, on its topical focus and - perhaps most importantly - on how complete freedom of speech was in the given country. No wonder, then, that among the countries of prewar Europe, German racist thought and practice at first had little influence in Italy, but this changed diametrically in the late 1930s, when the political situation enforced by signing an alliance with the Third Reich led to the passing of the so-called leggi razziali (racial laws), the Italian version of the famous Nuremberg Laws. They did not grow organically out of fascist ideology itself, but were rather a politically motivated 'implant' taken over from Italy's powerful ally. Hence the considerable degree of indifference that the elite of the Italian fascists exhibited toward racism. Due to the deep assimilation of Italian Jews, anti-Semitism was not a social problem in that country, and Mussolini distanced himself from racism in many of his statements from the early 1930s, claiming (e.g. in an interview conducted by Emil Ludwig in 1932) that "race is more a sentiment than a reality."235. Importantly, some of the high-ranking officials in Italy, as well as veterans of the fascist movement, were of Jewish origin, and the passing of the leggi razziali in 1938 became a personal and ideological tragedy for them. It was also in that period that Italian racist thought on music made its appearance. It was derivative of German writings, and in a sense complementary to them, as it attempted to create an 'antidote' for the glorification of the 'Northern genius' by reference to the great heritage of the 'Mediterranean race. The evolution of Italian ideology from the 'national awakening' to racism deserves a separate study and will be discussed in more detail further on in this book.

235 Emil Ludwig, Talks with Mussolini, (London: G. Allen \& Unwin 1932), p. 75. 


\section{Journalism and the Music Environment in Interwar Poland: “...Far-Reaching Caution Is Recommended”}

Comparison of the reactions of the music circles in Poland and England demonstrates some differences. In England attitudes varied greatly, whereas in Poland the dominant stance was that of maintaining distance. Already in 1933, "Kwartalnik Muzyczny" printed Bronisława Wójcik-Kepreulian’s review of Eichenauer's previously discussed book Musik und Rasse ${ }^{236}$. The reviewer maintains a matter-of-fact, balanced tone proper for a musicologist, presenting the book in the categories of scientific discourse. "When reading this book," she writes, "however fascinating its subject may be, especially in present-day circumstances - far-reaching caution is recommended..." Wójcik-Kepreulian quotes Jan Czekanowski's Outline of Anthropology ${ }^{237}$ and concludes that, despite the existence of a great number of publications describing "the mental qualities of the various racial components of humanity", these are all merely the impressions of journalists who "do not control or test their propositions by means of objective contemporary research methodology." Furthermore, "these presentations are sometimes not free of tendentious political colouring, which leads to diametrically opposed views. While militant German nationalism of the politicalanthropological kind believes that the best psychic qualities are inherent in the Nordic race and attempts to demonstrate that race's superhuman claims scientifically (emphasis as in the review), liberal Jewish writers go as far as to deny the existence of any racial differences and attributed all differences to the influence of the social environment." This review is an attempt at an unbiased presentation of the premises of nationalism as an ideological directive that determined the academic paradigms at that time. The words quoted above - written in 1930, cited in 1933 - could not take into account the later situation, the Nazi authorities' smooth passage from ideology to action, which elevated one of the previously described extremes to the status of official ideology, while the advocates of the opposite view were completely silenced and eliminated. Notably, the 'far-reaching caution’ postulated by Bronisława Wójcik-Kepreulian (albeit in a slightly different context) became the key quality of the vast majority of articles and press reports printed in Poland and concerning the music life of Poland's Western neighbour in later years, when the racial purges became a fact. In 1935, Zygmunt Grabowski reported: "The spectacle of transformations in German culture is something so

236 Kwartalnik Muzyczny, Nos 19-20, 1933, pp. 172-176.

237 Jan Czekanowski, Zarys antropologii, (Lwów [Lviv]: Lwowska Biblioteka Slawistyczna, 1930), p. 432. 
extremely complicated and at the same time misleadingly simple and provoking simplistic generalisations that [...] any judgments can only be passed with great caution in these circumstances." ${ }^{238}$ On the other hand, though, the same author noted the progressive 'nationalisation of art', its subordination to the ideology of Blut und Boden, and the demand of racial purity, which provoked some anxiety. A reserved and moderate tone also dominates in the reports sent from Germany by Max Meissner. In 1934 he wrote for "Muzyka":

"Following the recent political and social shake-up in Germany, Berlin's music life has not regained its lost balance yet. As we know, many of the most eminent artists, who contributed very intensely and effectively to German culture and art, and were of merit to our music, had to leave Germany owing to the Reich government's order. This has had a number of negative consequences for contemporary artistic life in Germany, as evident from the lowering of standards and the reduced intensity of music life in the state's main music centres..."239

Meissner does not mention the fact that the main reason for so many excellent artists leaving Germany (a situation which he finds deplorable) was the widespread racial purge. It is hard to determine now why this information was omitted. Meissner evidently treated the perturbations described in his report as temporary and believed that they would undoubtedly be overcome once full social-political stability had been restored. Most Polish critics also shared this view.

Rafał Ciesielski observes that Polish music critics noted the special place of music in national-socialist cultural policies:

"Critics ascertained this on the basis of the external presence of music in culture and life, determined by the new ideology. Their critical commentaries sometimes show that they have found the (officially decreed) position of music in the new circumstances very attractive, and admired the scale of its social influence under the new ideology."240

238 Zygmund Grabowski, "Niemcy po przewrocie" [Germany after the Political Revolution], "Życie sztuki” No. II, 1935, p. 302.

239 Max Meissner, "Stosunki muzyczne w Trzeciej Rzeszy" [Music Relations in the Third Reich], Muzyka No. 3 (113) 1934, pp. 125-126.

240 Rafał Ciesielski Refleksja estetyczna w polskiej krytyce muzycznej okresu międzywojennego [Aesthetic Thought in Polish Music Criticism in the Interwar Period], (Poznań: PTPN 2005), p. 360. Cf. also: Rafał Ciesielski, "Muzyka zagrożona? Polska krytyka muzyczna okresu międzywojennego wobec uzurpacji totalitarnych w muzyce" [Endangered Music? Polish Interwar Music Criticism in the Face of Totalitarian Usurpation in Music], in: Pokój jako przedmiot międzykulturowej edukacji w muzyce [Peace as a Subject of Intercultural Music Education], (Słupsk: Wydawnictwo Akademii Pomorskiej, 2007), pp. 228-239. 
And indeed, the statements of Grabowski, Prosnak, Różycki, and others (quoted by Ciesielski) stress the fact (also emphasised by Nazi propaganda) that music was an integral part of the nation's life and therefore its presence in all aspects of the collective life of the national community was necessary. They also stressed the comprehensive programme of the society's music education and of making artistic music available to a wide population. ${ }^{241}$ That these kind of state policies met with their approval (or even a kind of envy) is quite understandable. After all, many musicians expected this kind of support from the state, and this expectation was publicly expressed first and foremost by Karol Szymanowski ${ }^{242}$. Ciesielski believes that the generally 'overly neutral' attitude of Polish critics to the situation in Germany after 1933 resulted largely from their confidence in centuries-old German music culture and from the lack of any personal experience in this area. Those Polish musicians who had personal contact with musical life in the Third Reich explicitly signalled the major threats inherent in the new situation.

However, if we agree that no music critic works in a socio-political vacuum, one needs to ask - to what extent this 'neutrality' was part and parcel of the

241 Characteristic in this respect is the previously quoted anonymous report from Germany printed in the Chronicle column of Muzyka Polska in January 1936 (under the title Germany: The New Slogans). Its author writes with admiration about the methodical and well-thought-out programme of making music part of the nation's life. Rarely has music - as an applied art - played such a major role as "in today's new Germany", claims the author. In this way, we read, music is turning into a powerful tool of education and state formation. "We are thus coming back to old Plato," the author concludes. He highly praises the dynamic activity of the Reichsmusikkammer and expresses his regret that "So much has been said in Poland about creating an analogous situation..." Commentaries of this kind were pretty common and revealed an attitude of poorly concealed envy, expressed by such rhetorical questions as "Why do we not have it in our country?" Cf. anon. "Kronika- Niemcy- Nowe hasła", [Chronicle Germany - The New Slogans], Muzyka Polska, I 1936, pp. 80-82.

242 Szymanowski, as we know, supported the idea of a comprehensive system of state music education (which was only implemented after 1945) and demanded active educational policies as well as highly specialised, elitist training for artists on a good European level. However, as Magdalena Dziadek demonstrates, in times of crisis the government had to choose between an elitist and an egalitarian model of education. She suggests that it was the contemporary German and Soviet example that decided about opting for that latter model. Cf. Magdalena Dziadek, "Karol Szymanowski as Chancellor of the Higher School of Music In Warsaw. New Facts, New Light", in: Karol Szymanowski: Works - Reception - Contexts, ed. Zofia Helman, Musicology Today, 2008, pp. 94-117. 
dominant views presented in the press by the main political powers of pre-war Poland? What we mean is, naturally, the attitudes of the most representative and influential political groups toward the Third Reich on the one hand, and toward Jews on the other. As we know, despite major differences between the ruling bloc (the Sanation) and the nationalist movement, both camps expressed a preference for a 'strong-arm government'. This concerned both the idea of a 'national revolution' supported by Dmowski (the leader of the National Democrats) and carried out - as he wrote with approval in 1934 - only in Italy and in Germany, and the 'strong state' postulated by the ruling camp. However, while Dmowski was in favour of overthrowing the liberal order, he at the same time had distanced himself from the militarisation of political life that was typical of totalitarian states. He saw the introduction of military discipline in public life as a great threat because if everyone "thinks the same, it means that they think as they are commanded to, or in other words, they do not think at all." ${ }^{43}$ This view was shared by many activists and journalists in nationalist circles. The 1930s press contains many opinions similar to that of Jan Korolec, who proudly affirmed in Prosto z mostu (1935) that - contrary to the principle of 'herd obedience' that dominated the social-political life of Germany and Italy - Poland, owing to its traditions looking back to Jagiellon times, was likely to strike the balance between a strong state and the freedom of thought and speech $^{244}$. German economic progress was impressive, but the national press noted scrupulously and with growing apprehension the cases of Catholic Church persecution, ruthlessness and brutalisation of public life ${ }^{245}$. Critical voices also appeared in specialist and popular press - especially in historical magazines, which drew a parallel between the news of repression of dissident intellectuals as well as book burning

243 Quoted after: Roman Wapiński, Historia polskiej mysli politycznej XIX i XX wieku [The History of Polish Political Thought], (Gdańsk: ARCHE, 1997), p. 214.

244 Jan Korolec, "Czy slowo zaklęcia będzie powiedziane po polsku?” [Will the Spell Be Uttered in Polish?], Prosto $z$ mostu, No. 3, Warsaw 1935: "Fascism failed to reconcile introducing order with preserving the freedom of the individual (...) By hindering individual creativity, fascism is unable to create new life." The author accused German national socialism of the same mistakes. The Germans did not understand that "even the best trained flock of sheep will not be able to form a new life" (p. 4).

245 E.g., the Poznań-based Dziennik Narodowy No. 52, 1935 quotes the secret Gestapo circular aimed "against malicious criticism of national-socialist ideology by the Jesuits and other Catholic speakers," who, in case they are caught committing this kind of crime, ought to be immediately arrested (p. 2). 
in Germany and similar events taking place in ancient Rome ${ }^{246}$. Distrust for the Third Reich was also present (though well concealed) in the ruling camp. Despite officially good Polish-German relations, Marshall Piłsudski himself - if we can believe the accounts of his aides - had already foreseen in 1934 that this was a temporary harmony and the situation would change radically within four years $^{247}$.

As far as the attitudes to the Jewish population are concerned (which in prewar Poland was viewed more as a religious community than a national minority), there was a major difference of opinion between the Sanation and the nationalists, and the views on this issue also evolved in both of these two main camps. As we know from his earlier writings, ${ }^{248}$ Dmowski showed a preference for cool, matter-of-fact analyses of the historical role of the Jews in Polish history. He negatively assessed the early 20th-century domination of trade, finance, transport and other branches of modern economy by the Jews (in most territories of the old Polish-Lithuanian Commonwealth with the exception of the more highly developed Wielkopolska). However, he blamed the conservative attitudes and indolence of "Polish dandies" for this state of affairs, claiming that the Polish nobility saw enterprise and business-like attitudes as "a discredit to a gentleman's honour" and preferred to compete for the convenient "posts in state institutions", which were in the hands of the powers occupying Poland. In the later period, however, the National Democratic leader accused the Jews more and more often of preventing a strong middle class from developing in Poland. Irritated by the attitudes of well-organised Jewish groups- which during the Versailles Peace Conference preferred to negotiate with Western politicians without applying for his agency as a representative of the revived Polish state - he was more and more

246 Ignacy Wieniewski, "Habend sua fata - insignia" Filomata, Lwów, 1938 No. 101. The author recalls the Roman Emperor Domitian sentencing Arulenus Rusticus and Herennius Senecio for the crime of praising "enemies of the state", while their books were also burnt. Philosophers who could sympathise with the culprits were exiled. Wieniewski comments: "Publicly burning the books of dissident writers...Is this Domitian's Rome or Hitler's Germany? The fate of Rusticus and Senecio is now also the fate of the whole elite of German writers whom Hitlerism holds in disfavour, led by the genius of Thomas Mann..." (p. 527).

247 Cf. Mieczysław Pruszyński, Tajemnica Piłsudskiego [Piłsudski’s Secret], (Warszawa: Polska Oficyna Wydawnicza, 1997), p. 200.

248 Dmowski, Myśli nowoczesnego Polaka [Thoughts of a Modern Pole]. 
prone to accept the conspiracy theory and accused the Jews of actively contributing to all of Poland's historical misfortunes ${ }^{249}$.

Such views found numerous and eager followers ${ }^{250}$, but they were disputed even in the nationalist-Catholic circles themselves, and opposed particularly strongly by Józef Piłsudski, whose federationist visions entailed sensitivity and respect toward national minorities and whose authority guaranteed relative social peace in this area. Still, as late as 1935 the nationalist press accused the government of economic favouritism toward Jewish circles, of which the case of Jewish Zero-Interest Funds (which outraged minor traders and craftsmen) was supposed to be a key example. "Dziennik Narodowy" claimed that these funds were subsidised by several government departments while "the few Polish craftsmen's funds that exist are quite exhausted," so that a 'Christian' trader or craftsman must "visit several, sometimes a dozen credit companies" in order to obtain funds for his or her business, and usually "he ends up with nothing."251 It is hard to determine what motivated the officials of the Sanation government to this 'favouritism', but the obvious question is: Why could the respective 'Christian' circles not organise themselves as well as the Jewish ones? It must be stressed, too, that the press did ask such questions in this period. Since the economy was (especially during times of crisis) one of the main sources of conflict between 'Christians' and 'Jews' in prewar Poland (these were the categories used in that period), we can easily imagine what impact this kind of news had on the moods of those in society. As we know, after Piłsudski's death the Sanation came somewhat closer to a nationalist standpoint, at least concerning the Jews, and anti-Semitic sentiments began to spread in society, also affecting the intelligentsia. Magdalena Dziadek demonstrates in her research to what extent the

249 Dmowski, Przewrót [The Revolution] (1934), quoted after: Wapiński, Historia polskiej mysli, p. 194. Dmowski's conspiracy theories and anti-Semitic obsessions fully manifested themselves in his literary attempts of the 1930s, particularly in his novel Dziedzictwo [The Heritage] (1931). Cf. Andrzej Micewski, Roman Dmowski, (Warszawa: Verum, 1971), pp. 333-336.

250 According to the directives of the Camp of Great Poland (OWP) and All-Polish Youth, the status of a citizen ought to be distinguished from that of a person who 'belongs' but has no right to vote and is subject to restrictions and limitations similar to those imposed on the Jews in Austria-Hungary. The difference would be that baptism could not change this status, which excluded any chances of assimilation. This concept was criticised by the Catholic Church.

251 Anon. "Żydowskie kasy bezprocentowe stwarzają konkurencję polskiemu rzemiosłu" [Jewish Zero-Interest Funds Go into Competition with Polish Craftsmen], Dziennik Narodowy. No. 52, Poznań 21st August 1935, p. 5. 
staffing of managerial posts at music schools in the 1930s depended on being an 'ethnic Pole ${ }^{252}$. Toward the end of the decade such criteria were no longer a question of behind-the-scenes pressures, but were now openly applied. In 1937 limits were imposed on the access of Jewish youth to Polish universities, and the infamous 'ghetto benches' were introduced (student segregation). The former quota imitated the US and British practice of the day. The latter aimed at preventing violent behaviour (coming to blows) rather than strict racial segregation. All the same, these measures reflected the social atmosphere at that time.

The rise in anti-Semitism in Poland after 1934 suggests that it may to some extent have been fuelled by events in the Third Reich, possibly even inspired by the naive association of the propaganda of the German boom and rising prosperity with the progressive 'Aryanisation' of public life, economy and culture. On the other hand, however, one needs to remember that, unlike in Nazi Germany, Polish anti-Semitism was not an official state doctrine, but it manifested itself in the form of local conflicts of varying character and intensity, while state authorities made attempts to handle and resolve these conflicts rather than provoking them as in the Third Reich. The Polish state authorities and the Catholic Church for the most part supported assimilation and integration, while in Germany no assimilation was even considered, and the Jews - regardless of their religion and declared loyalty to the German state - could only leave the Reich if they obtained an entry visa from another country, which was by no means easy in practice. The ideological background was also different. In Poland the majority of nationalist organisations did not go beyond the concept of so-called 'integral nationalism', and the biological racism propagated by the Nazis found few followers. This was largely related to the strong influence of the Catholic Church on the programmes of parties and factions that declared themselves as upholders of Christian and national values. In his pastoral letter from 29th February 1936, Cardinal August Hlond, the Primate of Poland, warned Poles against "importing from abroad fundamentally and ruthlessly anti-Jewish ethical attitudes" because it was at

252 Dziadek, "Karol Szymanowski”, p. 102. Other sources show that such recommendations did not result exclusively from anti-Semitism. Maciej Gołąb quotes a letter (of 20.02.1938) from Prof. Adolf Chybiński to the director of Poland's National Library, Prof. Mierczyński, in which Chybiński recommends a young musicologist - Józef Chomiński - who "despite his Greek Catholic faith" considers himself as a Pole, stresses his links to Polish noble families, researches Polish music and writes in Polish. Cf.: M. Gołąb, Józef Michał Chomiński. Biografia i rekonstrukcja metodologii [Józef Michał Chominski. A Biography and Reconstruction of Methodology], (Wrocław: Wydawnictwo UWr, 2008) p. 33. 
odds with Catholic ethics. This warning suggests that some kind of fascination with the Nazi purges did exist among the most vehement anti-Semites in Poland.

Nevertheless, avoiding "ruthlessly anti-Jewish" attitudes did not mean rejecting the criticism of vices at that time stereotypically attributed to the Jews and those qualities of their culture that evidently clashed with Polish tradition. It is a fact that Jews fight with the Catholic church, wrote Cardinal Hlond, that they embrace freethinking ideologies and are the avant-garde of godlessness, the Bolshevik movement and subversive activity. The influence of the Jews on morals is disastrous, and their printing houses propagate pornography. It is also true that Jews practise deceit, make profit through usury and trade in white slaves. It is true, claimed the Cardinal, that the influence of the Jewish on the Catholic youth at schools is mostly negative in religious and ethical terms. ${ }^{253}$

From today's 'politically correct' point of view, these kind of accusations would surely call for proof. Did police statistics really confirm the greater susceptibility of one ethnic group to certain types of crimes? Even if confirmed, in modern public culture generalisations that offend a certain community as a whole are unthinkable. These, however, are present-day standards and they must not be projected into the 1930s. In that period, generalisations and stereotypes of this type were common throughout Europe, and public opinion was definitely more callous and insensitive than today. The criticism of generalised national qualities voiced in that period (whether fairly or not) need not automatically be viewed as an expression of hostility for the nation at which it was levelled. Today such statements would be condemned as anti-Semitic, but if we apply our own standards to the early 20th century, it may lead to such absurd judgments as accusing Paderewski or Dmowski of anti-Polish attitudes just because they criticised Polish national vices - especially those that led the Polish-Lithuanian Commonwealth to a catastrophe in the 18th century. Coming back to Hlond's letter, his conclusions leave us in no doubt as to his intentions, which were devoid of any hostility - just the opposite:

"In all fairness, not all Jews are like that. Many of them are true believers; honest, just and philanthropic people. In many Jewish families the sense of family bond is both sound and exemplary. In the Jewish world we know people who are ethically distinguished, noble and respectable. We may love our own nation better than others, but we must not hate anyone, Jews included. In trade it is recommendable to have a preference for our own businesses, to avoid Jewish shops and Jewish stalls at the fair. But we

253 Cardinal August Hlond, List pasterski [Pastoral letter] O katolickie zasady moralne [For Catholic Moral Principles], Poznań 29.02.1936, Postulatorial Centre of the Society of Jesus, www.patrymonium.chrystusowcy.pl, accessed 10.06.2014. 
must not devastate Jewish shops, destroy their merchandise, break windows and hurl bangers at their houses. We should protect ourselves from harmful moral influence of the Jewry, from their anti-Christian culture, and in particular - boycott the Jewish press and demoralising publications. But we must not assault Jews, beat and injure them, and we must not slander them. Also in a Jew we must respect and love a man and our neighbour, even if we cannot respect the unspeakable tragedy of that nation which was made guardian of the Messianic idea, the fruit of which is our Saviour. When the grace of God enlightens the Jew, he will come and greet his and our Messiah with genuine joy, and we too should greet him with joy among us Christians."254

As evident from the above, Primate Hlond (brought up in Silesia, active mostly in Wielkopolska) was favourable toward the social-economic ideas promoted in the 1930s by the national democrats in Poland (such as the famous slogan "buy from your own people, your own products for your own money"). He asks Poles to grade their attitudes: "we may love our own nation better than others" and "have a preference for our own businesses". All the same, in fundamental ethical questions his teaching is definite: "we must not assault Jews...", "also in a Jew we must respect and love a man and our neighbour." The final paragraph of his letter is a warning against provocations, which proves the Church hierarchs' good knowledge of the complex political situation in that period:

"Beware of those who incite to violence against Jews. They serve a bad cause. Do you know who gives them orders? Who profits from those riots? The good cause will gain nothing from such imprudent actions. And the blood that is sometimes shed on such occasions is Polish blood."255

Provocations suggested here by Hlond - possibly instigated by Nazi agents in Poland - were highly probable and fitted the image of the extremely complex relations between Poland and the Third Reich. Most recent studies prove that international relations were changing very fast in that period and - as Piotr Zychowicz suggests in his much publicised book The Ribbentrop-Beck Pact Hitler, who greatly admired Piłsudski for his victory over the Bolsheviks in 1920 as late as 1939 still planned to draw Poland into an alliance against the USSR. These revelations (though well known to British historians for a long time ${ }^{256}$ )

254 Hlond, List pasterski.

255 Hlond, List pasterski.

256 This is evident from the previously cited book by L. Mosley, which includes an extensive discussion of the conversation between Ribbentrop and Lipski during the famous dinner at Berlin's Adlon Hotel in the spring of 1939. 
have now also been confirmed by German historian Rolf-Dieter Müller ${ }^{257}$, who also disclosed the much regrettable statement made by the Polish ambassador to Berlin, Józef Lipski, that if Hitler solves the Jewish question, Warsaw should erect him a monument (!). Naturally, at that time nobody associated this 'solution' with mass extermination, which was beyond imagination by the current standards of civilisation. ${ }^{258}$

The above-presented facts and opinions characterise the atmosphere in which the Polish music environment functioned at that time. The National Democrats exerted much influence in that environment, and controversial (from our present-day point of view) opinions concerning 'the Jewish question' can be found also in several (rather marginal) texts by Szymanowski, most likely written in the early 1920s. Though the composer did not publish those texts (which only seems natural, considering the enormous role of three brilliant Polish-Jewish musicians - Rubinstein, Fitelberg and Kochański - in the popularisation of his music), his private convictions still seem interesting enough to dedicate to them a separate section of this book.

\section{Protecting Elitism: Szymanowski, the Grand Polish 'Aristocratic' Traditions and the 'Jewish Question'}

Reading these texts ${ }^{259}$ - some of which are just loose notes, thoughts evidently scribbled down, at the moment when they appeared - one cannot fail to notice a certain internal discrepancy, most likely resulting from a conflict between personal experience and ideas derived from books. On the one hand, Szymanowski presents a surprisingly severe criticism of the cultural-historical role of the Jews in European culture. On the other, the great artist was too sensitive not to be moved by the depth and expressive power of Mahler's music, and it is in the context of the latter that Szymanowski made some very interesting comments. In a text in which he opposes 'pan-Semitism' to 'pan-Aryanism' (tellingly put in brackets), Szymanowski expresses his regret that the National Democrats and their equivalents throughout Europe do not cooperate "not to lose touch with

257 Rolf-Dieter Müller, Der Feind steht im Osten: Hitlers geheime Pläne für einen Krieg gegen die Sowjetunion im Jahr 1939, (Berlin: Christoph Links Verlag GmbH, 2011).

258 In that period the 'solution' was interpreted as assisting the Jews in emigrating and finding their own place to live, in which their own state could be built. We must remember that many Jewish activists also supported this kind of Zionist ideas and campaigns.

259 Szymanowski, "Kwestia Żydostwa ” 
the deepest sources of our cultural consciousness, the hidden flame that is the only effective weapon against Jews..." The composer believes that finding such a weapon is necessary, considering the 'disruptive' impact of the Jewry's activities in contemporary culture. At the same time, "the Aryan spirit looks hectically and a bit chaotically for those sources, lost when Catholicism (not Christianity) was pushed to the background as a mainspring of culture..."

Worrying as these statements may sound, they are not an unequivocal admission of racist views. Szymanowski's standpoint could rather be defined as determined by 'history-and-class'. Later in the text we learn that for him, 'Aryanism' was a synonym for aristocratic quality in the best sense of the word - a deep rooting in the elitist values of the West's high culture - while he associated 'panSemitism' with cosmopolitan 'internationalism' pushing that culture into decline, and with bolshevism. Hence, he writes further, "a progressive in the rude sense of the word is nearly a synonym for a Jew." It seems that Szymanowski borrowed these anti-Semitic topics (i.e. his understanding of the historical and cultural processes) from Antoni Marylski's book The History of the Jewish Question in Poland (1912) ${ }^{260}$. This publication - very popular in the $1910 \mathrm{~s}$ - is a clinical case of the 'ruthlessly anti-Jewish' stance mentioned by Cardinal Hlond in his letter. Marylski not only attributed the worst vices to the Jews, but saw them as the demonic source of all evil in history. In fact he puts them outside and above history by claiming that, while "the history of other nations is a constant evolution and self-improvement, or else - complete decline, leading to annihilation and extinction (...), the Jews have petrified in their morally and spiritually destitute state, in their insufficient ability - and so they continue." ${ }^{261}$ Szymanowski's diagnosis was a bit similar. In his view, 'progress' or 'evolution' in Jewish psyche "is overall an illusion, because it takes place in the closed circle of fossilised racial features, like a series of new labels stuck to a bottle that has for centuries contained one and the same poisonous liquid..."262 However, once Szymanowski enters the domain of music, where he feels at home, his stance becomes much less radical,

260 Antoni Marylski, Dzieje sprawy żydowskiej w Polsce [The History of the Jewish Question in Poland], (Warszawa: Gebethner i Wolff, 1912). The date of this infamous publication notably coincides with the date of the deportation to the former Kingdom of Poland of large Jewish populations from other regions of the Russian Empire. This influx of Jews led to a rise in anti-Semitic sentiments and caused some nationalist circles to react. It was also at that time that the pogroms of Jews (mentioned by J. Reiss, see below) took place in Russia.

261 Marylski, Dzieje sprawy żydowskiej, p. 22.

262 Szymanowski, "Kwestia Żydostwa ”, p. 233. 
and in the case of Gustav Mahler he seems to forget completely about 'poisonous liquid' and yield to the charm of the great Viennese symphonist's works. Though in the opening section of his sketch entitled Mahler's Art he still makes a biting remark about the lack of depth in educated Jews' "opinions on art and philosophy," he does add a cautious "usually", and admits that those educated Jews can boast a "trained and complex intelligence". He finds the reason for this "lack of depth' not in stereotypical Volkist tales about 'sterile desert' or in racial deficiencies, but in the lack of "a passion for life instinct", as a result of which "the noble representatives of that race are for the most part infinitely sad." This sadness is an effect of "the fatigue of centuries", of their "too long and indeed too tragic existence." 263 Szymanowski also applies this highly literary thesis to Mahler himself, whose "art is moving to the highest degree and immoral in a sense." Szymanowski writes: "a noble Jew's smile is gentle and sad - the smile of an old wise man who has experienced the cruelty of life, but does not want to disperse the illusions cherished by the young. This is the smile I find in Mahler's music."

One can hardly help but notice that Szymanowski forgot about his reading and the generally accepted stereotypes in this sketch and followed his own artistic intuition instead, his own personal experience, which led him to conclusions quite the opposite of his previous claims. The very concept of 'noble Jews' is at odds with the thesis of the 'degenerating and poisonous' influence of the entire race, and also with Marylski's views. Furthermore, Szymanowski's honest admission that he listened to Mahler "with tears in my eyes (...) nearly forgetting about the music and loving this great, noble, infinitely sad Human Being" - is not just an apt summary of the essence of the genius of this Viennese master in an era of decadence and decline. This confession also seems to shed light on the truth about Szymanowski himself, about the contradictions inherent in his complex and colourful personality, which was emotionally intense, genuinely passionate and inspired by the depth of its aesthetic experience. This experience clearly proved the falsehood of prejudice and racial doctrines. A genuine, 'ruthless' anti-Semite (if I can use Hlond's term again) could hardly have admitted, even to himself, that probably the most 'Semitic' of history's great symphonists had such a profound artistic impact on him, not to mention calling such a composer 'great' and noble'.

In Szymanowski's comments we often sense his 'aristocratic' habits and manners, as well as the kind of polite and elegant nonchalance that the nobility (not only in Poland) typically exhibited toward Jews. Unlike the 'ruthlessly

263 Szymanowski, "Kwestia Żydostwa ”, p. 236. 
anti-Jewish' attitudes (of open hostility which would allow for no exceptions), Szymanowski's stance could be described as 'relative' or 'selective' anti-Semitism. His racially motivated and generalised dislike of the Jews does not automatically concern all the representatives of the Jewish nation. To a self-declared supporter of elitism and defender of 'high' culture, such as Karol Szymanowski, this 'aristocratic' type of anti-Semitism was directed mainly against 'ordinary' Jews, those who represented 'egalitarian' tendencies. Unlike Marylski, Szymanowski did not deny Jewish achievements, talents and their great potential for development ${ }^{264}$, though he complained that those 'noble' Jews were not very numerous.

Finally, we must remember that Szymanowski - like Wagner before him could well claim that he was an artist in all that he did or wrote. Therefore we should not overemphasise the internal contradictions in his writings or see them as an expression of a logical and consistent ideology. On the other hand, one could ask to what extent Szymanowski's private views were shared by others in the Polish music world at that time? To what extent were such views representative? This question is quite justified in that the majority of Polish composers in that period, and of the Polish intelligentsia in general, descended from the landed gentry or nobility. Moreover, the National Democrats (whom Szymanowski supported) were very popular in music circles. Is it possible, then, that the Polish critics' rather feeble reactions to racist purges and persecution in Germany could be caused by their more or less camouflaged anti-Semitism? Could they consider those purges as a price that must be paid for the national homogenisation of society - a price perhaps not too high, considering the scale of the state patronage of music and musicians in the Third Reich? Or - a more likely hypothesis - could the critics' stance reflect the Polish Sanation government's policy of neutrality and non-interference in the internal affairs of both totalitarian neighbour states? We must leave these questions without simple answers.

\section{The Polish "Rassenkunde”: Józef Reiss and His Research on "The Jewish Spirit in Music"}

The aforementioned advice (formulated by Bronisława Wójcik-Kepreulian) to exercise "caution" when talking of racial issues in music, especially with reference

264 In the sketch Kwestia żydostwa [The Jewish Question] Szymanowski presented two contradictory views which were very widespread in the 1920s: While some denied any artistic talents and abilities to the European Jews, others claimed, conversely, that "the talents and abilities of the European Jews, and their role in art are undeniable, though they never reach the level normally required from an artistic genius." (p. 238). 
to Jewish culture - becomes understandable after 1933, because this hot and potentially explosive subject also became at that time a strongly political one. Previously, however, it was considered "safe" enough to produce a Polish version of the musicological Rassenkunde, one example of which can be found in the vast treatise by Józef Reiss, published in instalments in the fortnightly "Muzyk wojskowy" ("The Military Musician") ${ }^{265}$. Its author was a well-known musicologist, lecturer, music journalist and activist. In his text, he obviously followed in the footsteps of German authors, more specifically by the previously mentioned Heinrich Berl, whom he actually quotes and who represents an attempt to define the immanently Jewish qualities in European music. Berl also takes up the then much discussed (see above) questions of the existence and impact of suprahistorical 'racial' features determining the identity of a given culture.

Reiss's point of departure is an attempt to discover the Jewry's most typical quality, which he defines as "its mysteriously paradox nature." The paradox results from the history of a nation of "wondering exiles, who - despite the most severe persecution, scattered throughout the world - have survived through millennia." This paradox is also the clash of exuberant individualism and collective "psychology of the masses" propelled by "a concordant rhythm of religious sentiment," and the contrast between mystical longings and a strong sense of reality, a coldly calculated kind of realism. The conditions and brutal fate developed in Jews' exceptional powers of adaptation, and the main factor of the community's integration has been ritual synagogue singing. What is reflected in these songs is "boundless sorrow, inconsolable longing and melancholy lyricism" - qualities which Reiss interprets after Berl and the German Volkist tradition as an emotional reflection of the landscape. "The soul of the desert is enchanted in this song." 266 Having analysed the melodic structures of synagogal songs, Reiss concludes that they are mostly based on melodious declamation centred on one sound, balanced by richly ornamental sections. These - as Reiss calls them - typically Oriental qualities of Jewish music also include "an affected tone, bathos and expressive paroxysms." But the drama of the Jews, living as they do among alien cultures, lies according to Reiss in the fact that "a Jew can no longer be himself, but is unable to become anything else, to creatively collaborate with the alien society." As an example of this kind of tragic conflict, Reiss quotes the figure of Mendelssohn, whose great artistic talent, he reminds us, was recognised even by such avowed anti-Semites as Wagner, who, however, criticised Mendelssohn for

265 Józef Reiss, “Dusza żydostwa w muzyce”\{[The Jewish Spirit in Music] Nos. 9-14, 1928. 266 Reiss, “Dusza żydostwa”, Muzyk Wojskowy, No. 9, 1928, p. 3. 
"the lack of sincere accents that could inspire the heart..."267 Reiss summarises Wagner's famous anti-Semitic pamphlet and concludes that, paradoxically, it undoubtedly did them a great service since "it awakened the creative powers dormant in the soul of the Jewry, but previously stifled by alien culture."

It is hard to establish precisely the relationship between the reception of Wagner's pamphlet and the evident explosion of the European Jews' activity in the fields of music composition, performance, and the organisation and management of musical life. All the same, Reiss's historical overview proves that the "Jewish element" was present in European music from the time of Hans Neusiedler's 16th-century tablatures and Italian Renaissance madrigals (A. Gabrieli Ebraica), mostly as a caricatural ingredient or as an Oriental colour. It recurred throughout the 19th century in the works of Chopin, Mussorgsky, Liszt, Rimsky-Korsakov, and R. Strauss. Reiss also lists musicians of Jewish origin who were active in Europe since the Middle Ages, arguing that the apogee of their activity in early music came during the Italian Renaissance, which was extremely open to their contributions. In this context Reiss mentions in particular the Dukes of Mantua, renowned for their patronage of Jewish musicians, one example of which was the brilliant career of Salomone Rossi ${ }^{268}$. After his death, no major composer emerged from the international Jewish community for the next two centuries. Still, as Reiss claims, music must have attracted the Jews "as a sphere of the subconscious, of instinct and emotion. No wonder that they used their powers of accommodation, their unusual sensitivity and subtle sense of insight into everything foreign - to absorb, and soon to conquer this new field of artistic creativity." Reiss describes how in the 19th century, Jewish composers empathised so perfectly with the national styles that several of them even achieved the status of 'models' in this field. For instance Mendelssohn, the "ideal representative of Romanticism in German music"269, gained fame as a master of "sentimental lieder", to which he gave their complete form. Bizet - whom Reiss calls "the most Romantic of all composers" - was also of Jewish origin. And, eventually, what can be "more Parisian" (asks Reiss rhetorically) that the famous Cancan from Offenbach's Orphee aux Enfers? Anton Rubinstein, on the other hand, was the actual father of Russia's professional music tradition, while Mahler led Beethoven's symphony-cantata form to the point of such "overemphasis" that its further development was virtually impossible. The 19th-century Jewish

267 Reiss, “Dusza żydostwa ”, Muzyk Wojskowy No. 10, 1928, p. 3.

268 Reiss, "Dusza żydostwa ", Muzyk Wojskowy No. 11, 1928, p. 3.

269 Reiss, "Dusza żydostwa ”, Muzyk Wojskowy No. 13, 1928, p. 2. 
contributions in the spheres of music organisation, management and publishing were even more impressive. All this organisational and economic infrastructure demanded substantial investments and - as Reiss stressed - the readiness to take risks in financial terms, especially when promoting new artistic trends. Reiss explains the successes scored by the Jews in all kinds of popular music genres and in the field of music performance (in which, he claims, they became global leaders) by pointing out their tremendous powers of accommodation and their ability to absorb elements of foreign cultures. However, perfect assimilation has its negative sides, especially for those who "abandoned the banner of Jewry. [...] Unfortunately, in such circumstances a Jew knows neither limit nor proper tact," writes Reiss, and criticises Mendelssohn, Meyerbeer and Mahler for artificiality, insincerity and exaggerated pomposity in their handling of religious themes. Mendelssohn, whose "oratorios and church music were to blot out the memory of his Jewish origins" were sometimes "more ecclesiastical than the Church itself" in these kinds of works, and as a result they "offend the ears with insincerity and some alien tone." Reiss extends the same charges to Meyerbeer, and in both cases he falls back on the authority of 19th-century critics (such as Heinrich Heine and Robert Schumann). Though his criticism of Mahler was not supported by documents from the reception of his music, its tone of distrust for Jewish neophytes - converts to Christianity - is quite characteristic and worth quoting 270 , since it also frequently recurred in the early decades of the 20th century:

"And finally, was in not something distasteful on the part of G. Mahler to use the hymn Veni Sancte Spiritus in his Symphony No. 8? Can we talk of sincere inspiration in this case? The words of this mystical hymn can arguably have a true emotional value only for a born Christian of deep faith."

Reiss also protested against the assimilating tendencies in 19th-century synagogal music, which - in so-called "progressive temples" - was ornamented in the fashion of Christian liturgical music, with the addition of choirs and organ, while old synagogal chant was forcibly adapted to the principles of functional harmony: "What represents the purest and most noble expression of the heart overflowing with religious passion in an Orthodox synagogue, in the modern temple becomes a mere show and a caricature!"

Reiss sums up his treatise with the conclusion that "the Jewry has indeed had its brilliant composers, but it has not created Jewish music." What, after all,

270 To mention only the figure of Prosecutor Jadassohn from Heinrich Mann's satirical novel Der Untertan. 
do the works of Mendelssohn, Meyerbeer, Bizet and Anton Rubinstein have in common? - he asks rhetorically. He then calls upon the post-Romantic dualist aesthetic opposition between form and content and argues that "the forms of their works are those of Western European music, and it is not Jewish in spirit. Where national identity and an awareness of one's race are absent, their art always remains cold and distantly removed from life." This is why - despite Mendelssohn's technical and formal mastery - his music "oozes such coldness, and frequently even tedium. What do his 'songs without words' tell us today? Are they not to us 'songs without content and without a soul'?" However, Reiss admits that Mendelssohn also wrote some (or a few) brilliant works, the greatest of them being the Violin Concerto in E Minor, which he describes with unfeigned admiration as:

"an unequalled poem, the fruit of genuine inspiration. What is the secret of such compositions? They contain a subconscious element that informs the music of Mendelssohn, but also that of Offenbach, Bizet, Rubinstein and G. Mahler: namely, the soul of the Jewry! The call of its blood! Blood penetrates the external tissue of form, because blood is the unifying ingredient that nothing can destroy."

Reiss does not explain in what way this "spirit of the race" manifests itself in Mendelssohn's Violin Concerto. Also in the case of Offenbach and Bizet, he rests satisfied with such comments as that Daemon's Aria from Les Contes d'Hoffmann is "Jewish throughout", or that the 'fate' motif from Carmen has an Oriental colour. Traditionally, like many other authors exploring "the spirit of the Jewry" - Reiss focuses on Mahler, whose music combines well-known paradoxical contraries: "moments of greatest inspiration side by side with trivial folk 'Gassenhauer' melodies and naïve nursery songs, or military march rhythms."271 This paradox - which cannot be solved in aesthetic terms - is easy to explain once we realise that it is the result of "Mahler's Jewishness - despite his breaking away from the Jewry!” Thus Mahler's mystical-Talmudic longings (which Reiss attributes to the strong influence of the poetry by Siegfried Lipiner) overlap with "the Jewishness that subconsciously flows through his soul." Racial instinct, claims Reiss, also manifests itself in the use of children's choirs, frequent in Mahler's symphonies. Where does this come from? Reiss's resolute answer is supposedly based on some unspecified scientific research: "It undoubtedly results from certain mental predispositions characteristic of the Jewry. It has been proved that Jews more than any other race have a strongly developed longing for the time and land of childhood. Living among alien national entities,

271 Reiss, “Dusza żydostwa ” Muzyk Wojskowy, No. 14, 1928, p. 1. 
the Jew experiences a tragic sense of isolation, and seeks sanctuary in the past to which he escapes..." Reiss refers to Max Brod, author of the treatise Heidentum, Christentum, Judentum (1921), widely discussed and popular between the world wars, and wonders whether the frequent march stylisations in Mahler's music really reflect his childhood experience of the garrison orchestra's rehearsals in the barracks near the Mahlers' home - or perhaps they draw on the Eastern European tradition of Chassidic songs, which usually exhibit march rhythms. Reiss admits that Mahler did not know those songs but "who knows - perhaps deep in the subconscious regions of his soul he discovered the same tone, akin to the soul of the Jewry!"272 Reiss eventually concludes that the more or less disguised "racial instinct" is present in the music of all composers of Jewish origin, regardless of the degree to which they assimilated to their host cultures. He finds evidence of this, among others, in the music of Arnold Schönberg, "the leading figure of contemporary German music" and his Pierrot Lunaire with its characteristic Sprachmelodie. Could it be that this technique "is derived from the spirit of synagogal recitative songs?" asks Reiss rhetorically again.

As we have seen, Reiss values most highly those works by composers of Jewish origin in which - from behind the masks of Western European form and technique - one can supposedly hear the mythical "voice of the blood" or "spirit of the race". The tragic split between the East and the West can be healed in the future, he believes, by clearly defining one's cultural identity on the basis of one's own national tradition, the wealth of folksong repertoire and authentic synagogal music. It was on the foundation of these traditions that artistic Jewish music experienced its revival - the first symptoms of which appeared, significantly, in Tsarist Russia in the last years before the 1917 Revolution:

"As from the pain and suffering, from the persecution of our nations, there sprang the inspired Romantic poetry of the three Polish National Bards - so also from the tears of the persecuted Jewish nation flowed the stream of national consciousness and the flourishing of a new life. The Russian 'Yevrey', harassed by pogroms, stood up and fought against political oppression, hand in hand with the Russian intelligentsia, united with it by a common ideal." 273

As in the case of all the earlier national schools, this national revival also began by collecting and documenting folk songs and other ethnographic material scattered throughout the vast Russian Empire. This work was coordinated by a society founded in St. Petersburg in 1880, and divided into sections located in

272 Reiss, "Dusza żydostwa" Muzyk wojskowy, No. 14, 1928, p. 2.

273 Reiss, "Dusza żydostwa " Muzyk wojskowy, No 14, 1928, p. 1. 
other major cities of the Empire. Based on these foundations, original artistic works began to appear, composed - interestingly - by artists belonging to radically different musical environments as far as artistic ideals were concerned. On the one hand, there were the pupils of the leading Russian national composer Nikolai Rimsky-Korsakov (who included Mikhail Gnessin and Ephraim Shkliar) - the natural followers of a folk-national revival. On the other, however, we can observe a certain paradox. Jewish nationalists belonged for the most part to the circle of Alexander Scriabin - known for his cosmopolitan and eccentric Messianist views, whose sense of mission, mystical ambitions, prophetic tone and nearly priest-like attitude proved particularly attractive to the Jewish nationalists. Also important was the visionary imagination of this brilliant pioneer of multimedia art, who was an ardent follower of the idea of Gesamtkunstwerk, but "did not inherit" the racist views of its founder - Richard Wagner...

As evident from above. Reiss's treatise fuses various tendencies characteristic of the first three decades of the 20th century. The concept of the crucial role of sincerity and authenticity in art, and the need for national affiliation and natural 'rooting' in one culture, without which art would be spiritually void, corresponds to the aesthetic stance of such artists as, for instance, Sergey Rachmaninov and Ralph Vaughan Williams. On the other hand, Reiss's representation of the music written by composers of Jewish origin in terms of the dichotomy between 'Western form' and 'Eastern spirit' clearly (though not always consistently) draws on Heinrich Berl's publication, already discussed here, which Reiss must have been well familiar with. Though the Polish author accepts the thesis (expressed in many later German publications) concerning the decisive role of 'racial instinct' in the identity of a work of art, similarly to Berl he avoids aprioristic value judgments. Moreover: his concept of "the soul of the Jewry" is definitely more philo-Semitic than anti-Semitic. He combines the erudition of a carefully educated musicologist with interest in new fashionable trends in human sciences. Like most academics in that period, Reiss followed the "news from the wide world" and asked the same questions that his generation was frequently concerned with. Admittedly the ideological basis of Reiss's interpretations comes dangerously close to the "impressions of the columnists" mentioned by Czekanowski in his sober commentary. Nevertheless, in the interwar period explaining e.g. Mahler's symphonic orchestration or his obsessive use of march stylisations with 'racial instinct' could seem just as revealing and meaningful to many readers as the earlier Freudian analyses. Today we dismiss the concept of race-specific talents as a curiosity, similarly as research into the call of 'Polish blood' in the works of great Russian masters of Polish origin, such as Stravinsky, Shostakovich, or possibly even Tchaikovsky (?!). Rather than 
pursuing such claims, we are interested in how and why Jewish communities in different European countries succeeded in promoting the talents of those in their religion, and why other cultures did not take advantage of the same tools and methods. But, as we have said before, every generation asks its own questions and tries to answer them in its own characteristic way.

\section{Zofia Lissa: The Problem of Race in Music}

Another scholar who took part in the Polish debate on racial issues in music was Zofia Lissa, who in the 1930s was a young and ambitious scholar just embarking on a brilliant academic career. Considering the later well-known MarxistLeninist views of this unquestioned star of Poland's postwar musicology, as well as her Jewish origins, some readers may find it surprising that as late as 1934 she still spoke approvingly of Rassenkunde and saw major cognitive potential in anthropological research on the racial aspects of artistic phenomena. It should be stressed, however, that she clearly distinguished between research on human races (which agreed with current scientific views) and racism as a political doctrine aiming to establish the hegemony of one race over another. She stated this difference clearly in her article The Problem of Race in Music, drawing wide historical parallels and arguing that:

\footnotetext{
"The most fatal complications usually occur when a scientific notion leaks prematurely to the masses. Lacking academic precision and separated from the entire edifice of knowledge of which they are but a part, such ideas become - in the wrong, unauthorised hands - a dangerous weapon and a germ of hatred between people. It was so at the time of Copernicus, Galileo Galilei and Giordano Bruno, whose scientific achievements were viewed as - first and foremost - a heresy. It was so in the middle of the last century as well, when Darwin formulated his theory of evolution in nature (...) and the same is now happening to Einstein's theory of relativity. A similar fate has now befallen anthropology, and one of it notions in particular - that of race."274
}

Lissa's thesis that the central social and political issues of the 1930s (especially in Germany) were the result of a 'leak' of ideas isolated from the 'edifice of knowledge' from academic circles to the 'wide masses' - is debatable. Many other scholars of the day approached the problem of racial inequality in the same way as the crowd swayed by politics and ideology. All the same, Lissa's diagnosis of the current state of affairs (presented further on in her article) is very far from any kind of 'caution', and, from the historical perspective, proves astonishingly

274 Zofia Lissa, "Problem rasy w muzyce" [The Problem of Race in Music]. Muzyka No. 3 (113) March 1934, p. 108. 
correct - the more so that it demonstrates how ideology combined with the mechanisms of social psychology stands above science and politics. It is an ideology created at the given time by influential circles in accordance with the popular 'fashion' and resulting in a kind of 'political correctness' which becomes an unwritten compulsion to accept the official standpoint:

\footnotetext{
“'Race', 'racism, 'Nordic qualities' - these are perhaps the most fashionable and popular terms used and unfortunately also abused today. These categories are now applied by everyone, by the great and the small alike. They are the ideas that steer the minds of the crowd. But unfortunately it is not merely another verbal deluge, a trendy 'ism' and a mental epidemic! Today racism already has terrible, bloody consequences - from the lynching of US Negros and the crimes committed by the Ku-Klux-Klan to the excesses of Nazi storm-troopers. Racism is a problem that is becoming a major burden on present-day life and politics, while the prospects for the future are even more tragic. Racism is an attitude to life that sweeps away everything human (ZL's own emphasis) in men and mostly brings out what is zoological in them!"275
}

However, as the young Polish researcher observed - while in social life racism was becoming a dangerous political weapon, in the field of science "it opens up very interesting questions, provides a new vantage point and a perspective for the study of phenomena." It should be noted at this point that the use of the term 'racism' (as a positive label) with reference to scientific studies seems highly unfortunate. The author apparently failed to notice that in academic life the meaning of 'racism' is precisely the same as in the broadly understood social reality. But - as we replace that misnomer 'racism' with 'the study of the human races', which, as the context proves, is what the author had in mind - we may disregard terminological inaccuracies and get to the main point. Lissa's answer to the question whether race is reflected in music is an unequivocal "Yes, and very strongly so." Racial identity entails differences in "the psychic constitution of composers," each of whom - Lissa claims - "is deeply rooted in his or her race or nation" and "demonstrates specific musical qualities related to them, even when he or she changes the place of residence, the environment and conditions of life." It is a fact, she writes, that not only "the various races, but even individual nations stemming from one anthropological line of development differ in their culture and art in a constant and distinct manner."

With reference to music, the author points to two fundamental types of differences. The first one results from what Lissa refers to as 'racial psyche', responsible for the difference of content in musical works, whereas the other

275 Lissa, "Problem rasy", p. 109. 
concerns the choice of sound material, the fundamental ingredients of the music. These two aspects are closely related to each other. For instance, as Lissa argues, the Chinese or Indian ways of dividing the octave, different from that used in Europe, causes that "the music of those peoples seems quite incomprehensible or even worse - out of tune - to the European ear." As a consequence, Western audiences are unable to grasp "the inner content of that music." Of special note is Lissa's claim that "even within more narrow territorial and historical boundaries, in the course of the last millennium of European music history" racial differences have been very strong, despite the use of the same sound material throughout the continent:

\footnotetext{
"These differences are more concealed in this case and lie in the psychic (emphasis ZL) content of the musical works themselves. Their reflection in the structure of those works is only a later consequence. The different psychic content of music compositions results from a different way of reacting to sound phenomena, which is specific to a given nation or race and leads to differences in the type of creative predisposition."276
}

These racially motivated creative predispositions manifest themselves in the way the music impacts the audience through four spheres that together make up the work as a whole. The most sophisticated of them, that of musical structures, appeals mainly to the intellect of the listener. The most direct one is the sphere of sensual impressions. "If we look at the entire history of the musical development of various European nations." Lissa writes, "the consistent predominance of some creative predispositions in certain national groups is clear that it immediately suggests itself." Romance nations - particularly Italians and Spaniards - characteristically pay much attention to "the beauty of sound" in the form of attractive melodies and rhythms. France (which Lissa discusses as a separate subcategory) has excelled since the Renaissance period in naturalistic and illustrative music, while Slavic nations focus on the emotional sphere in their music.

"The history and development of music among the Germanic nations - in England, Germany and the Netherlands - betray quite the opposite kind of musical talent, in which intellectualism and speculative quality are the predominant components. Polyphony, which originates among the peoples of the north, from Dunstable to all the Netherlandish schools, to Bach and Handel, as well as the support given to musical form by the Viennese classics, and even the contemporary music of these nations - all point to the predominance of the intellectual element. All this proves the presence of a constantly recurring type of creative predisposition characteristic of that race."

276 Lissa, "Problem rasy", p. 109. 
However, Lissa warns her readers not to see the above described regularity as a rule without exceptions. In some situations, the spirit of the age or a powerful artistic individuality proved stronger than these racial or national predispositions, and went beyond them, producing a synthesis of the tendencies of the given epoch, of the race and of "the individual psychic constitution" of the composer. All the same, from the perspective of the "entire development of music among the various racial groups in Europe," these regular lines of development resulting from racially determined predispositions must not be overlooked.

Reading Lissa's text reveals her intellectual background, her rooting in the solid tradition of German music theory and psychology, and especially in the 20th-century development of those disciplines, which is evident in her frequent references to "internal and external" aspects of the music work and to its "psychic content". On the other hand, she demonstrates a typical 1930s fascination with the cultural aspects of research on human races, and many of her theses (such as the notorious association of polyphony and musical intellectualism in general with the Nordic race) appear dangerously close to the conclusions presented in the previously discussed publications by Berl, Matzke and Eichenauer. But Lissa also shows her indebtedness to another heritage - that derived from her philosophy studies at Lwów University under the supervision of Professor Twardowski, founder of the famous Lwów-Warsaw school of philosophy and mathematics, which postulated, among others, a humanisation of mathematics and making the humanities more scientifically precise. Evidently aware of the dubious character of the similarities that her research bore to that of her German counterparts, and aiming at maximum precision in her statements, at the end of her paper Lissa once again distanced herself from any political contexts of the research on race. Racial classifications, she claimed, cannot be used as a basis for any value judgments passed on human groups, their ideas and art, nor can it justify one race's claims to hegemony over the others.

This article, written by a would-be exponent of Marxism-Leninism who despite her young age - had already obtained her doctorate five years earlier - may surprise us today with her overdue enthusiasm for the then fashionable "racial theories" and the scant interest she shows in the influence of the social environment - which was crucial in Marxist theory. It is difficult precisely to establish when Zofia Lissa's fascination with communist ideology began - but by the time of her next article on the subject of race, printed in 1938, the then 30-year-old Lissa had evidently undergone some kind of ideological metamorphosis. At the same time, the latter text is highly emotional - possibly because it was dedicated to Chopin, a composer on whose music she would write many excellent works in the future. But this is already the subject of the next subchapter, which deals with 
the rather curious (from today's point of view) debate on the "racial identity" of this most eminent representative of the Polish Romanticism.

\section{Chopin and the Question of 'Racial Purity'}

The question of racial "purity" or "identity" was discussed in the 1930s not only in the context of the Nazi dogmas discussed above. Sometimes the debate involved pride related to a family's past and origins, and especially to the fact of there being no undesirable 'admixtures' of plebeian or Semitic blood in the examinable history of the given lineage. This concerned both aristocratic families and wider communities, including national ones. It was this aspect - criticised by Lissa as 'zoological' (and indeed there was an analogy between pure-bred horses and the 'breeding' of people believed to represent the 'purest' and therefore best specimens of the given race). Despite the opinions of some authorities at that time, who warned their audience against the 'pernicious' effects of mixing human races, the application of this 'aristocratic' stance to artistic genius provoked opposition from many ideological groups and perspectives. While Zofia Lissa limited herself in her paper to the brief comment that contemporary anthropology was extremely sceptical with respect to the concept of racial purity, Ignacy Jan Paderewski - one of the greatest musical authorities of the day - expressed his opinion (in the context of the current situation in the Third Reich) much more bluntly:

\footnotetext{
"Racial purity? What nonsense! Who can be so stupid? Can you quote just one example of a perfectly 'racially pure' genius? If we were to accept as truly German only those German composers whose biographies agree with these fashionable theories - who are racially 'pure' Aryans - then where should we place Beethoven? Or Mozart, whose surname some philologists might derive from the Polish 'mocarz', meaning a strong man of power? And what about Wagner's eminently non-Aryan nose? What about Mendelssohn? Before the [Great] War, a group of leading German scholars produced an extensive academic study on the racial purity of Germans, but [emperor] Wilhelm did not permit its publication. Why? Easy to guess. He was told that according to this study, the vast majority of Germans are not racially Germanic, and not even Aryan..."277
}

This text, which appeared in 1934, is a printed version of an interview given by the old master of the piano most likely a year earlier. At that time Paderewski could not know that the question of Mendelssohn's 'racial identity' would soon be officially and definitively decided by the official authorities. Nor could

277 Ignacy Jan Paderewski, "Myśli, uwagi, refleksje” [Thoughts, Comments, Reflections], Muzyka No. 2 (112) 1934, p. 50. 
he imagine that the debate on 'racial purity' would soon also affect (albeit in a different context) Chopin. What was at stake were not the possible Semitic connections of the composer's ancestors (the above quoted Nazi researchers of that time did not level such charges against the master of the mazurka), but a hypothesis that presented such connections as an asset. This was understandable, because the said claim was formulated in Poland, where probably all the existing political and ethnic groups agreed as to a favourable, frequently enthusiastic opinion of Chopin, and, besides, the authors of this hypothesis were the Polish Jews, whose cult of Chopin was frequently as strong as that exhibited by ethnic Poles - and who gave the world one of the most eminent Chopin interpreters, Arthur Rubinstein. Though the ensuing debate in the Warsaw press was rather curious and short-lasting, it is worth noting, because it reflects the climate and interests dominant at that time.

1938 saw the publication in Poland of Mateusz Mieses's book entitled Poles Christians of Jewish Origin ${ }^{278}$. Its author was a specialist in Judaic studies, a philologist, and a Polish Jew. His aim was to familiarise the Polish reader with the very little known scale to which the ethnically Jewish element had penetrated over the many centuries into the families of Polish landed gentry, intelligentsia, and even the aristocracy, and as a result - Mieses claimed - many eminent Poles known in Polish history had some Jewish blood in their veins. The author was inspired to take up this subject by the current situation. In the preface he complains that under the influence of new ideas flowing from Germany - the 'zoological' type of anti-Semitism began to spread in Poland, which led to more and more different societies and associations wanting to become judenrein, "not only in the religious, but also in the anthropological sense." They were unaware, explains Mieses, that "our symbiosis with Poles-Christians (...) has proved favourable and invigorating" in every field. As a result of many centuries of Jewish neophytes penetrating into the Polish elite, in fact none of those elite Polish families could be quite sure that they had no Israelites among their ancestors. Mieses studies family bloodlines on the basis of armorials and various memories, and quotes numerous examples of Jews being baptised and, as a result, frequently Polonising their names (e.g. from 'Brunstein' to 'Brunicki'); this process was also combined with admitting them into the Polish nobility. Among many more or less convincing examples of such assimilation, Mieses also quotes some rather dubious ones, including the following comment concerning the genealogy of Chopin:

278 Mateusz Mieses, Polacy-chrześcijanie pochodzenia żydowskiego [Poles - Christians of Jewish Origin], (Warszawa:Wydawnictwo M. Fruchtmana, 1938). 
"Fryderyk Chopin, a musical genius, not only had a French father, but his mother was a [Jewish] neophyte. The well-known poet Antoni Lange wrote in his brochure entitled On the Contradictions of the Jewish Case (1911) that Chopin was half Jewish through his mother Justyna Krzyżanowska. I do not know Lange's source for this information, but it is a fact that 'Krzyżanowski' was a typical neophyte name (...), and Chopin strongly resembles a Jew in the shape of his nose and the expression of his eyes in the portrait."279

Mieses's conclusions with reference to Chopin - as well as his entire methodology - were sharply criticised by the reviewer of "Wiadomości Literackie" cultural weekly known by his pen name of Quidam, who accused the author of an unreliable approach and lack of solid source documentation, and of basing his claims on pure speculation and unconfirmed clues:

"Mr Mieses," he writes in his review, "would like - without much work or effort - to find the largest possible number of noble families having Jewish blood in their veins. Therefore he uncritically accepts every most trifling piece of gossip as proof and draws far-reaching conclusions from most illusory circumstantial evidence."280

Quidam calls Mieses's claims concerning Chopin's supposed lineage "reckless and flippant", pointing out how at another point the same author admitted that "the surname Krzyżanowski need not always indicate a neophyte." Talking of a figure of Chopin's stature, writes the reviewer, the author's "elementary duty was to examine his lineage and either refute the gossip or else support it with clear arguments." It should be stressed that Quidam did not treat Mieses's claims as any kind of 'blasphemy' - just the opposite. At the end of his review, he regrets that:

"The subject of this book - if studied with proper care - could have been of fundamental importance for the debate concerning the Jewry. It could have shown the traditions and the range of the Jewish presence in Poland, so that the absurdity of applying racism consistently to Polish history would have become evident..."281

While Quidam did not refer to Mieses's rash conclusions concerning Chopin's 'racial identity' drawn from his facial features as represented in an unidentified portrait, it was Zofia Lissa who spoke out on this theme. In her article Concerning the 'Race' of Fryderyk Chopin printed in one of the later issues of "Wiadomości Literackie", the scholar opposed "Mieses's superficial claim" to the results of "long-term studies on the anthropological structure of Chopin," so that

279 Mieses, Polacy-chrześcijanie, p. 77.

280 Quidam, "O Polakach pochodzenia żydowskiego" [On Poles of Jewish Origin], Wiadomości Literackie, No. 774, 1938, p. 6.

281 Quidam, "O Polakach", p. 6. 
the contemporary "myth of race", already blown out of proportion, should not be nurtured even further. ${ }^{282}$

According to Lissa, establishing Chopin's 'racial affiliation' is difficult due to the lack of reliable and objective sources. For a long time, all his images available to researchers had been either portraits or sculptures, that is, "artistic creations that deformed his face and figure to a greater or smaller extent." Interestingly, when we compare drawings, portraits and descriptions originating in different "anthropological environments", it turns out that in Polish and French circles, artists mostly emphasised the Armenoid features of Chopin's face, while Germans underlined the Nordic elements. However, claims Lissa, most of his portraits point to his Dinaric characteristics, which are also confirmed by the two surviving real-life likenesses of the composer (referred to by the author as "racially unprejudiced material") - namely, his death mask and the only preserved daguerreotype. The Dinaric type (very common in France, but rare in Poland) was (believed to be) a result of a mix between the Armenoid and Nordic races. Therefore Lissa moves on to a detailed study of the composer's face and the sum total of the descriptions of his figure in order to establish which of his features reflected the Armenoid, and which - the Nordic type. She eventually concludes that the Nordic element was poorly marked in Chopin and that the master of the mazurka was, all in all, "a typical Dinaric with some prevalence of the Armenoid element." 283 He inherited this type from his father Nicolas Chopin, who - as we can glean from descriptions and from his surviving portrait - was also "a typical Dinaric". On the other hand, the portrait and the existing descriptions of the composer's mother suggest Nordic features, and it was from her that Fryderyk inherited his few physical traits characteristic of that type. Mieses's speculations concerning the possible Jewish ancestors of some families bearing the name of Krzyżanowski require a closer study, says Lissa, but "her typically Nordic traits seem to contradict this claim."

Lissa, however, does not rest content with these conclusions concerning the physical evidence of Chopin's 'racial affiliation'. She further observes that in accordance with the principles of contemporary anthropological psychology "racial differences between people are the foundation of psychic identity" and therefore influence character, temperament and the entire psychic structure conceived as "a set of intellectual, emotional and volitional predispositions." On the

282 Zofia Lissa, "W sprawie 'rasy' Fryderyka Chopina" [Concerning the 'Race' of Fryderyk Chopin], Wiadomosci literackie No. 778, 1938 p. 7.

283 Lissa, "W sprawie 'rasy'”, p. 7. 
basis of the documented biographical data, the Polish scholar concludes that, beyond any doubt, the composer's spiritual profile "fundamentally agrees with the model of Dinaric psyche presented by the anthropology of race"284 - and refers at this point to the theory of Hans Günther (previously discussed here). Such qualities of Chopin's character as a strong sense of humour (he was quite a joker) and feeble will, combined with a short temper, lack of resolution, moodiness, sociability combined with strongly pronounced secretiveness, sensuality, a strong love of his fatherland, as well as outstanding talents for acting, mimicry and music - all perfectly fit Günther's Dinaric type of psyche. And here comes the surprising bit. Lissa writes:

"Chopin's music does not correspond in any way to what the anthropologists of race have established as the qualities of Dinaric art (Günther) and of their music in particular (Eichenauer). None of the qualities attributed to other Dinaric composers' music can be traced in the works of Chopin. On the contrary, it has all the qualities proper to the Polish social and ethnic environment in which he grew up..."285

Chopin's music is thus a strong argument against racist theses, Lissa argues. It is not race but rather the social and ethnic environment that determined the character of Chopin's oeuvre. This character did not change even when Chopin lived in France and "absorbed the influences of that culture in which the Dinaric type finds its fullest and most proper expression," she concludes.

The first impression a present-day reader of this paper will get is most likely astonishment at the seemingly paradoxical fact that a scholar of Jewish descent draws on Nazi theories formulated by German anthropologies to show that Chopin had no demonstrable Jewish ancestors. But if we place this debate in the context of its own time, and of one specific period in the ideological and scientific evolution of Zofia Lissa herself - things do not look so simple any more. Her emphasis on the role of social environment and her rejection of Eichenauer's theses concerning the impact of 'race' on the character of the music - testify to Lissa's intensifying links with Marxist-Leninist ideology, which she most likely began to absorb in that very period. Her motivation for taking part in this debate was most likely the academic ethos which aims at objective truth regardless of whether that truth is convenient at the given time and place. In fact, at the end of her article Lissa emphasises that she decided to shed light on the issue of Chopin's 'race' because it is "not only racists make demagogical and tendentious

284 Lissa, "W sprawie 'rasy", p. 7.

285 Lissa, “W sprawie 'rasy", p. 7. 
use of the notions of anthropology, but also those who, quite rightly, fight against fascism and are themselves affected by the consequences of the 'myth of race."

What is untypical of the normally very meticulous and no-nonsense approach represented by Lissa is the complete lack of musicological arguments which she could have used to support her thesis concerning the decisive impact of the social-ethnic environment of the composer's childhood and youth on his entire oeuvre. Lissa explained this lack by asserting that "Wiadomości literackie" was a magazine targeting wide circles of the intelligentsia rather than expert musicologists, and that for the latter group she had completed her extensive study entitled Chopin in the Light of Anthropological Research. The latter study, announced in her article, was to be published in one of the first Chopin annals prepared (according to Lissa's own words) by the Fryderyk Chopin Institute during that period. Unfortunately the publication never saw the light of day, and the typescript was lost, most likely sharing the tragic fate of Poland's capital. When Zofia Lissa returned to ruined Warsaw after many years' stay in Moscow, she was clearly reluctant to return to subjects which - in new ideological and political circumstances - no longer belonged to priority research topics.

In communist Poland after World War II, the official cult of Chopin was just as strong as in prewar Poland, and Szymanowski's claim that Chopin had created "the myth of the Polish soul" was still widely accepted. Both before and after the war, the figure of Chopin continued to function in Polish society as an integrating factor. In a sense, Chopin was also a symbol of the continuity of the Polish state, which - ever since its resurrection in 1918 (owed to a very large extent to Ignacy Jan Paderewski, who was a world famous interpreter of Chopin and at the same time the first prime minister of reborn Poland) - held Chopin's legacy in the highest reverence as one of the foundations of Polish national identity, which in a sense gave Chopin the status of a 'state composer ${ }^{286}$.

286 Notably, before WWII one of the main institutional promoters of Chopin's cult was the Polish Ministry of Foreign Affairs, and the founding committee of the Fryderyk Chopin Institute (est. 1934) also included - apart from the luminaries of Polish culture including Karol Szymanowski - the head of this ministry, Józef Beck. The Polonaise in A Major was used as the signature tune of Polish Radio Channel One, and Warsaw hosted one of the world's most important piano competitions - the Chopin Competition. Chopin's identification with the Polish state was also confirmed abroad albeit in a rather peculiar fashion. According to an anonymous correspondent of "Muzyka Polska" (January 1936), in Modena the eminent Italian musicologist Nino Salvaneschi delivered a paper entitled Chopin's Spiritual Struggle. The correspondent concludes: "It is curious that in Italy Chopin can be talked about in public, but he cannot (...) be played, since - according to the most recent directive of the Ministry of 


\section{The Reactions of British Music Critics, the Appeasement and the British-German Policy for the Musical Cooperation of "Germanic Sister Nations"}

Though the opinions of British critics varied greatly (as we have already mentioned), in these circles one can also find many statements which suggest that their authors were 'under the spell' of Nazi revolutionary cultural policies and their results. Moreover, British writers were frequently much more open in their admiration for this policy than Polish writers, and some of their texts (despite being published in titles independent from state authorities) seem to have accepted Neville Chamberlain's government policy of appeasement toward Hitler's hostile attempts. One example can be "The Musical Times", whose editors - judging by reports from Germany printed in that monthly - evidently underwent an ideological metamorphosis in the 1930s, evolving from resolute criticism to cautious acceptance, albeit not entirely free of reservations. In January 1934, "The Musical Times" published a brief and laconic review of Eichenauer's Musik und Rasse. The author, who signed his text with the initials M.D.C., notes that the book, completed in August 1932, "anticipated with surprising accuracy the line of Germany's new musical policy." The reviewer then briefly presents Eichenauer's main theses, emphasising his main assumption, namely that:

"part-writing, harmonic or polyphonic, as a basis of musical art, is entirely a nordic invention and that alone the nordic race, and accessorily the dinaric, have created and maintained the main traditions of musical art, the 'opposing forces' having been and still being many, from the Italian verists to the Russian nationalists, and, inevitably, the Jews" [spelling preserved from the original - translator's note]. ${ }^{287}$

Having perfunctorily presented several examples of Eichenauer's racial classification of composers, the reviewer sums up the role of artists of Jewish origins, a disproportionate number of whom were described as producers of "musical trash". Unlike artists of other races, Jews involved in atonal,

Work and Propaganda - he was deleted from Italy's musical programme as a composer from a state that takes part in the sanctions." The directive was evidently some kind of retaliation for the fact that Poland had supported the League of Nations sanctions against Italy after the latter's invasion of Abisinia. This was, however, a mere episode which had no major impact on the reception of Chopin in Italy or on the good relations between the two countries.

Cf.: anon., "Kronika:Włochy" [Chronicle: Italy], Muzyka Polska No. I 1936, p. 80. 287 Anon. (M.D.C.) review of 'Musik und Rasse' by Richard Eichenauer, The Musical Times Vol. 75, No. 1091, 1934 p. 40. 
quartertone-based music or other avant-garde projects "have at least the excuse of belonging to a race to which harmonic part-writing is fundamentally alien." This ironic remark leads to a conclusion which proves the reviewer's critical opinion of Eichenauer's book.

"Students wishing to investigate the basic and really significant factors of the problem, music and race, will, I think, find little to help them in Herr Eichenauer's contributions."

Eichenauer's speculations were criticised even more sharply by Edward Lockspeiser, who in his review written for "Music and Letters"288 accused the German admirer of the Nordic race of manipulating historical facts and being an ideologist in the service of the Nazi party. Lockspeiser commented:

"One must indeed be naively prejudiced to fit the history of music onto the theory of Nordic racial supremacy. In fact, to identify the spirit of seventeenth century Italian opera with spectacularism, to ignore the importance of Gabrieli's influence on Heinrich Schutz, to maintain that Gluck, as well as Jomelli, Traetta, Sammartini and Rameau, embodied the essence of Nordic ideals, is not merely biased but unhistorical. Herr Eichenauer further purports to prove that the disintegration of our musical values is due to 'denordization' - not only in Germanic countries, but in Latin countries as well! This thoroughly conforms with the tenets of a certain political party in Germany of whose ideology this book is evidently a product." 289

The tone of these reviews, printed in both of Britain's leading music periodicals, suggests that the reception of Musik und Rasse in the British Isles probably fell far from its author's expectations. There is also no indication that the readers of these magazines exhibited any closer interest in the topic. It is possible that many of them viewed Eichenauer's 'revelations' as some kind of harmless academic speculation, but the quoted reviews prove that their authors had already been fully aware at that time of the Third Reich putting these ideas into practice. In the summer of 1933 Victor Gollancz publishing house brought out The Brown Book of Hitler Terror - which, according to Samuel Hynes, had a significant bearing on the attitude of a large proportion of the British intelligentsia toward the Third Reich $^{290}$. In November of the same year, “The Musical Times" published a devastating report from Germany by the famous musicologist Alfred Einstein,

288 Edward Lockspeiser, (review of) "Musik und Rasse von Richard Eichenauer", Music and Letters Vol. 11, No. 2, April 1933, pp. 185-186.

289 Lockspeiser, (review of) Musik und Rasse, p. 186.

290 Samuel Hynes, The Auden Generation, Literature and Politics in England in the 1930s, (London: Faber and Faber, 1979, pp. 130-131). Hynes's opinion was confirmed by Susan D. Pennybacker, though she also noted the inaccuracies of The Brown 
who had fallen victim to the first racial purges and was forced to emigrate to England. This extensive account of the various aspects of Germany's musical life presents a dreary picture of the first effects of the Gleichschaltung policy, growing bureaucracy, and especially of the racial cleansing that opened up chances for power and promotion to mediocrities as long as they were loyal to the authority. Information that reached the British audience, thanks to Einstein, overlapped largely with what Max Meissner communicated to Polish readers in his previously quoted account - but Einstein's report was more precise and abounded in specific details, as well as attempting a historical analysis of the causes of the phenomena he was describing. The main difference between the two articles lay in their tone. Einstein's text was far from any kind of 'caution', and frequently betrayed the author's bitterness at the situation:

"In the Germany of today the treatment of music from a political standpoint is a systematic application of the term 'Gleichschaltung' in a sphere where such application is unwarranted. It is a misuse of the appellation 'volkstümlich' (at present more properly said 'volksverbunden'); a misconception of the popular, national spirit; it is the arrival of mediocrity, which thinks its opportunity has come, and before which more enlightened spirits must yield. I am not speaking of the expulsion of hundreds of directors, conductors, singers, teachers who have lost their posts, not through any lack of capability, but because they are Jews or politically unacceptable. I am not talking about the loss of artists such as Walter, Klemperer, Huberman, Schnabel, and a host of others, whose ranks have been joined, of their own free will, by Toscanini, Cortot, Casals, Busch - the new State snaps its fingers at them, and, seemingly indifferent, allows foreign countries to enjoy the benefit of their worth. I will not enlarge upon the impoverishment of German concert life, bad enough it is." 291

Apart from issues of quality, Einstein also quoted a telling figure: In early october1933, the London press announced approximately 40 concerts and other music events taking place in Britain's metropolis over a period of just two weeks, whereas in Berlin there were just four in the same period. The effects of political and racial purges coincided with the peak of the Great Crisis, which reduced subsidies for cultural institutions, led to the closure of opera houses and the disbanding of orchestras. And "worse is yet to come"292.

Book.: Susan D. Pennybacker, From Scottsboro to Munich - Race and Political Culture in 1930s Britain, (Princeton and Oxford: Princeton University Press, 2009), p. 208.

291 Alfred Einstein, "The Present State of Music in Germany", “The Musical Times” Vol. 74, No. 1089, Nov. 1933, pp. 977-978.

292 Einstein, “The Present State”, p. 978. 
While Einstein's pessimism proved justified with reference to racial cleansing, his predictions concerning the intensity of concert life and the state's support for music institutions did not come true, or at least not until the outbreak of the war. The return to economic prosperity after the crisis soon translated into a statistically reflected increase in the number of music events. It was probably for this reason - or to prevent accusations of being 'biased"293 - that the editors began to publish reports diametrically different in tone, written by Nancy Fleetwood, a British singer residing in Dresden, who stressed the political enthusiasm of the German 'national revival', the immense commitment of the Nazi authorities to the promotion of musical culture, and the spectacular flourishing of all aspects of music life in the Third Reich, both in terms of quantity and quality. Fleetwood's reports betrayed her own strong personal fascination with the changes in Germany, as well as possibly some degree of naivety. A typical example of her writing is her extensive account of the Reichstheaterwoche, a festival held between 27th May and 3rd June, which she praised with admiration: "It was really incredible how many operas, concerts, plays - not to mention 'Kundgebungen' (...) - were crammed into eight days, and still more incredible that the opera house, concert halls, and theatres, were packed to overflowing for every performance." ${ }^{294}$ This enthusiastic presentation leads her to a very heartening conclusion: "This only serves to prove that come what may, Germany is and the present Government certainly intend that shall continue to be - a nation of music-lovers and theatre-goers." The author derives this certainty from the activity of the Third Reich's supreme authorities:

"Hitler and many other prominent members of the Government set the good example by being present themselves at the opening performances in the opera house, and Dr Goebbels - who was responsible for the Festival - remained in Dresden during the greater part of the week and visited [the] opera or playhouse each evening." 295

The German Minister of Propaganda made a particular impression on Nancy Fleetwood thanks to his speech, in which he declared that:

293 Eric Levi suggests that this change of tone may have resulted from the German critics' very sharp reaction to Einstein's report. The editors of The Musical Times evidently did not have the intention to engage in a "verbal war" with their German colleagues. Cf.: Levi, Appeasing Hitler?, p. 26.

294 Nancy Fleetwood, "Musical Notes from Abroad: Germany," The Musical Times, Vol. 75 No. 1097, 1934, p. 655.

295 Fleetwood, “Musical Notes”, p. 655. 
"the State intends to undertake everything possible to promote theatrical art, especially German art and artists and, more especially, German music. Moreover it is to be made possible for every class of the people to visit the opera and theatres regularly; opera, drama, and music are to play an important part in the education of the rising generation, and are no longer to be regarded as luxuries for the favoured few."296

No wonder that such a cultural policy must have been to a musician's liking (both in England and in Poland). The notion of the price that would have to be paid for this in the future was then still rather hazy. Predictably, the more sombre aspects of life in the Third Reich, such as racial persecution, were omitted from Fleetwood's reports ${ }^{297}$. Today it is difficult to decide whether this was the result of a fascination quite common among music critics in that era, and to what extent her reports were influenced by the fact that she lived in Germany and was part of that country's musical life $\mathrm{e}^{298}$. Fleetwood strongly emphasised the scale of the German state's financial support for opera houses and other artistic institutions. The latter aspect generated a natural interest and undisguised envy in British musicians who - like many of their Polish colleagues - would gladly have welcomed similar policies in their own countries. An idea was even put forward that Britain should create a new ministry, the Ministry for Fine Arts, for the purpose of administering arts. A debate flared up in this context in "The Musical Times", which involved some rather curious arguments which, however, did not sound strange to the readers in the 1930s. One of the magazine's correspondents went as far as to claim that even "a country as non-musical as France" had its ministry responsible for the arts, which provoked a reaction from US musicologist Gilbert Chase (a specialist in the music of Latin countries) who warned against

296 Fleetwood, “Musical Notes", p. 655.

297 The only criticism concerning the Reichsmusikkamer was its excess of bureaucracy and the imposition of taxes on artists, not the question of racial persecutions. Cf.: Nancy Fleetwood, "Musical Notes from Abroad: Germany", The Musical Times Vol. 79, No. 1142, April 1938, p. 305.

298 This "conflict of interest" is distinctly evident in most of her reports, and especially in her praise of the Dresden Opera and its director, where she informs that the Reich's Chancellor himself decided to let him continue his work in this post, while the musical standards of the house were superior to anything that similar institutions in Europe could offer (Nancy Fleetwood, "Musical Notes from Abroad: Germany", "The Musical Times", Vol. 75, No. 1096 (June 1934), p. 555). In her report of April 1938 Fleetwood also modestly mentions her own recital of British songs broadcast by the Reichsrundfunksender Berlin on 22nd April 1938. Cf. Nancy Fleetwood, "Musical Notes from Abroad: Germany", The Musical Times Vol. 79, No. 1142, April 1938, p. 305 . 
rash attribution of some talents or their lack to entire nations ${ }^{299}$. Chase argued that such claims are rather a matter of 'personal opinion' and of the considerable difference in music tastes on the British and French sides of the English channel. He also corrected the correspondent, pointing out that France only had an arts department in the Ministry of Education, but no separate ministry - and rejected the naïve claim that having such a ministry bore any relation to the society's musicality and the musicians' welfare. Besides, who will persuade a pragmatic-thinking British taxpayer to support another bureaucratic body with 'cushy jobs' for officials, which will mediate in taking money from some and giving it to others. Here, however, there came an energetic response from the British Fascist Party, which solemnly promised to the magazine's readers that it would immediately put the idea of the ministry of arts into practice once it has taken over power in the country. The editors realised that this was really too much - this time on the pro-fascist note - and the debate was closed so that it could not be used for the purpose of obvious political agitation ${ }^{300}$. Nevertheless, the magazine continued to print text which more or less openly praised Nazi cultural policy. The culmination of this trend was Michael Bell's extensive report in the February 1938 issue of "The Musical Times", which showed such clear approval, even admiration, for the Third Reich's policies, especially in the field of music, that the author felt obliged to make the following reservations in the introduction:

"I realize that, in this most intolerant of all democracies, I run the risk of being labelled at least a Nazi propagandist and probably a Fascist when I attempt to put down a few random thoughts dealing with the place of music in the National-Socialist State. In reality my attitude to totalitarian institutions is scrupulously indefinite, since I find too much praiseworthy in them to become a decided antagonist, alongside too much blameworthy to be an out-and -out admirer."301

299 Chase Gilbert, "The State and the Fine Arts in France", The Musical Times Vol. 75, No. 1101 (Nov. 1934), p. 977.

300 To sum up the debate, the editors published a statement in which they assured readers of their political neutrality: "The article in our March issue dealing with the potentiality for good of a Ministry of Fine Arts was entirely non-political and made no reference to fascism or anti-fascism. Since the resulting correspondence has, without our help, taken that turn, it will now cease." Cf.: Henry B. Raynor and Robert Stevens, "Letters to the Editor - Fascism and Ministry of Fine Arts", The Musical Times, Vol. 75, No 1098 (August 1934), pp. 737-738.

301 Michael Bell, "Music in Nazi Germany", The Musical Times, Vol. 79, No. 1140 (February 1938), pp. 99-101. 
Leaving aside the author's highly provocative thesis concerning Great Britain in his time as "the most intolerant of all democracies," his declared neutrality is not really confirmed by the rest of his text. Bell deplores the lack of proper attention and appreciation of the crucial role of music in the Third Reich on the part of British commentators. "Yet no government, one may safely say, was ever filled with such idealism in respect of the art of music and the place of the arts as a whole as that of the present regime in Germany." The author supports this thesis with the words of Peter Raabe (as we remember, he was Richard Strauss's successor as head of the Reichsmusikkammer), who declared his trust in the Nazi state because it recognised the fundamental role of art in the nation's life. Bell repeats the German authorities' declarations previously quoted by Nancy Fleetwood that art would no longer be a luxury available only to the chosen few, but would become an essential element of social life, and "the prime element in that culture of the personality which parallels the culture of the mind and the culture of the body in a mutually interactive triad." Hence, as Bell observes, in contemporary German the term 'Kultur' has a broader significance than its English counterpart, 'culture', since in German it denotes "all that ennobles a faculty or faculties of the individual." What follows is an enthusiastic description of the state's wide range of activities aiming to improve the level of the general public's music education, including a favourable presentation of the work of the Reichsmusikkammer, inevitably critically compared (as in some Polish critics' sighs of "why not here") with the situation of music and musicians in Bell's own country.

All the same, Bell does note some inconsistence between the Chamber's longterm plans and the state's policies, mainly in the racial sphere:

"It is, for instance, difficult indeed to make the Chamber's balanced attitude in any way consistent with the Nazi ban on non-Aryan and other performers and composers - an attitude that has caused so much indignation outside Germany. The non-Aryans have been caught in the specious argument that as they are not themselves true to their fatherland (indeed, they cannot be expected to be since they are not Germans), how can they assist in that spiritual development of the nation which consists in making men 'tuchtig, gut und vaterlandstreu'? The forcible expulsion of many and the voluntary departure of others has undeniably inflicted a hurt on German musical life. To the evident antiNazi this hurt is irreparable, but although I have every sympathy with these outlawed musicians, I am afraid I cannot see any reason why in point of fact their removal should produce any permanent ill effect on music in Germany; this is probably the somewhat callous attitude of the German Government." ${ }^{302}$

302 Bell, "Music in Nazi Germany", p. 100 
Bell evidently cultivated a highly diplomatic language, which - as one of his readers ironically observed - suggests that he himself was not quite sure of the correctness of his theses ${ }^{303}$. On the one hand, he accepts the arguments of the Nazi authorities as apparently right, he supports what he calls Raabe's sensible and balanced plans and expresses his sympathy for the oppressed "non-Aryan" German musicians. On the other, however, he clearly underestimates the problem and seems to sympathise with the view of biological racists, who - as we know did not recognise perfectly assimilated Jews born in Germany as Germans, thus denying their own national self-identification and declarations of loyalty. Bell's standpoint provoked a response from one of the non-Aryan musicians settled in England, who tried to make the British readers awake to the fact they usually failed to observe - namely, that in the public space of the Third Reich there was room for only one, officially approved ideology, whose dogmas had to be followed by scholars working in all disciplines:

'It is hardly a 'specious argument' which, before being able to approve of an artist's work must needs know his origins! There might, indeed, have been some sense if it were found possible to judge an artist's origin by his work, but that is out of the question, and not a single common factor, which could be called 'non-Aryan', can be found in the works of, say, Schönberg, Mahler, Mendelssohn, Bruch and Meyerbeer..."304

One should note that in the last sentence of his report Bell suggests that the possible reason for racial cleansing lies in the rather too 'callous' attitude of the German authorities. This opinion, claims A.J.P. Taylor, interestingly harmonises very well with the dominant reaction of British society to the Nazis' anti-Semitic excesses at that time.

Hitler's rise to power, as Taylor observes ${ }^{305}$, rather divided than integrated the British political class. Though both the left wing and the Tories were equally

303 Thomas A. Russel, "Letters to the Editor: Music in Nazi Germany”, The Musical Times Vol. 79, No. 1141, March 1938, p. 216. The reader criticises Bell for ignoring the mass racial purges and penalisation of 'racially undesirable' persons and for dismissing these and other atrocities committed by the Nazis as mere 'callousness'.

304 G.F.D. (anonymous) "Letters to the Editor: 'Music in Nazi Germany', The Musical Times, Vol. 79, No. 1142, April 1938. pp. 286-287. In the same letter we find an ironic response to Bell's curious theses concerning the lack of tolerance in England: "May I add that, unlike Mr Bell, I do not find this English democracy at all 'intolerant'? If he had been living in Germany and had written half as sympathetically about Mendelssohn as he has about 'Music in Nazi Germany', he would probably have lost his livelihood!...” (p. 287).

305 A. J. P. Taylor, English History 1914-1945, (Oxford: Oxford University Press 1975), p. 461. 
critical of the new German authorities, their motives were different, which in the long run led to mutual distrust and accusations. At the same time, most British people embraced the principle of non-interference in other countries' internal affairs, especially with reference to world superpowers. However, the Nazi anti-Semitic actions made the British of all social classes break this rule and speak with one voice on this matter. On the other hand, however, there was a kind of quiet anti-Semitism then quite common in England, which manifested itself, for instance, in the Jews not being admitted to many prestigious clubs and in the application of the numerus clausus at many famous schools and universities. Taylor therefore believes that the critical reaction of the Britons was provoked by the Nazis' barbarian methods as such, and he concludes: “...some English people were no doubt the more annoyed at having to repudiate the anti-Semitism which they had secretly cherished." 306

Another aspect of the post-1933 anti-Semitic purges in Germany discussed by Taylor is that they eventually worked to the benefit of Great Britain, which willingly took advantage of the brain drain and welcomed (under the guise of humanitarian action) famous scientists, artists and financial tycoons who fled the Third Reich ${ }^{307}$. When Bell declared his disbelief in the long-term harmfulness of racial cleansing to German musical life, he was probably well aware that this process had permanently enriched the culture of his own country, despite creating competition for British musicians.

In order to present a fuller picture of the reactions of the British intelligentsia toward Hitlerite racism, we should also tackle the very important question from the standpoint of academic circles in the UK, which enjoyed global recognition and authority. Studies conducted by Gavin Schaffer, Susan D. Pennybacker and Elazar Barkan ${ }^{308}$ proved that the attitudes of British scholars (and in particular of anthropologists and biologists) were far from monolithic. All the same, already

306 Taylor, English History, p. 514.

307 Taylor, English History, p. 514. A typical example is the story of the naturalisation of Sigmund Freud, who (after the annexation of Austria by Hitler's Germany) was admitted into Britain by the authorities without all the usual formalities and procedures, obtaining citizenship in just one day. We know that obtaining a residence permit, not to mention the naturalisation for a German Jew of the lower social strata was very difficult, and the process took several years.

308 Gavin Schaffer, Racial Science and British Society 1930-62, (Basingstoke: Palgrave Macmillan 2008); Elazar Barkan, The Retreat of Scientific Racism: Changing Concepts of Race in Britain and the United States between World Wars, (Cambridge: Cambridge University Press 1992); Pennybacker, From Scottsboro to Munich. 
from the late 1920s onward they began to withdraw their previously enthusiastic acceptance for racial typologies and were becoming progressively more sceptical with regard to the possibility of unequivocally demonstrating to what extent man's psychic predispositions are determined by heredity, and to what extent by the environment in which he or she lives. According to Barkan, after 1933 the majority of researchers rejected Nazi biological racism as absurd (this is mainly evident in private correspondence), though few announced this rejection publicly before the end of the decade ${ }^{309}$. The publication of Julian Huxley and A.C. Haddon's book We Europeans ${ }^{310}$ in 1935 proved a major event. The work was later reissued and widely commented in the press ${ }^{311}$, which frequently emphasised the authors' anti-racist stance. According to Huxley and Haddon, the concept of 'race' as applied to human beings is vague and hard to define in scientifically verifiable terms. The authors quote numerous examples in order to demonstrate that the study of 'race' ought to be replaced with research on ethnic groups or nations. However, some other scholars, such as e.g. Reginald Gates, represented views that were closer to those of the German anthropologists.

Studies dedicated to this period stress the influence of the political atmosphere, public opinion and the expectations of various influential pressure groups on the official standpoint of the scholarly community. Barkan observes:

"The public demand was for anthropology to define race scientifically and rename it. Most anthropologists followed this intellectual trend against racism and shifted the subject matter of their research from the biological to the cultural. For many the transformation preceded the Second World War, but the British scientific community followed the government's policy of appeasement, and prevented the shift against rigid racial typology and, by implication, against racism, from receiving formal approval"312

It is hard to determine nowadays to what extent this discrepancy between British academics' privately expressed views and the official standpoint of various academic associations resulted from political pressure from the authorities, and to what extent it was an expression of spontaneous support for the government's policy. The latter hypothesis is quite likely as it agrees with the conciliatory attitudes characteristic of the intelligentsia at that time, frequently

309 Barkan, The Retreat, p. 279.

310 Julian Huxley, Alfred C. Haddon, We Europeans: A Survey of "Racial" Problem, (London: Cape, 1935).

311 Elsworth Huntington, "Exploding the Idea of Race", The Saturrday Review, 29 February 1938, p. 5.

312 Barkan, The Retreat, p. 296. 
noted by historians and resulting from a paralysing fear of armed conflict with Germany. That fear seemed well justified, especially when Germany's military power (frequently exaggerated, as we now know) was compared with the potential of Great Britain, poorly armed and unprepared for war. In such a situation, avoiding formal approval for the scientific critique of biological racism, which for the German Nazis was a type of quasi-religious dogma - corresponded distinctly with the policy of the British government.

Another form of support for the appeasement policy and consequently for a growing rapprochement between Britain and Germany was provided by the Anglo-German Fellowship - an organisation of influential politicians, journalists and businessmen, which from the beginning of its operations (1935) actively cooperated on - among other things - a musical exchange between Germany and Great Britain. This programme of exchange and collaboration in the field of music, initiated by the German side, had its hidden racist undertones, albeit they derived from a quite different context. It reflected Hitler's policy of German-British rapprochement, which he still insisted upon in the mid-1930s. The policy was to lead to an alliance and agreement about the division of the imperial spheres of influence that Hitler sketched in Mein Kampf. Music - as Eric Levi ${ }^{313}$ proves in his study - was to play an important role in this process of these two 'racially closely related' Germanic nations coming closer together. Especially attractive for the English was the prospect of German concert halls, normally hermetically closed to foreign composers, opening up to admit British music. This project gained impetus in 1935, when Joachim von Ribbentrop, a well-known admirer of British culture, became the Third Reich's ambassador to London ${ }^{314}$. Both the Anglo-German Fellowship and the Permanent Council for International Co-operation between Composers (headed by Richard Strauss) were involved in this project. The latter council had been founded in 1934 in Wiesbaden as an alternative to the International Society for Contemporary Music, which Germany left in 1933, accusing the ISCM of promoting composers of suspect racial origins and overly 'modernist' music ${ }^{315}$. One of the German side's first initiatives was to grant the University of Hamburg's Shakespeare Prize to Ralph Vaughan Williams (1936). The choice of the composer was rather

313 Cf. Eric Levi, Appeasing Hitler?, pp. 19-36.

314 Ribbentrop took up his London post in June 1935 and in the same year Germany obtained Great Britain's permission for increasing the size of the German Navy. He was also one of the key initiators of the Anglo-German Fellowship, Cf. Kalor Grynberg, Bolesław Otręba, Joachim von Ribbentrop, (Warszawa:Książka i Wiedza, 1995).

315 Cf. Eric Levi, Music in the Third Reich, (New York: St. Martin’s Press,1994), p. 93. 
obvious; he was also a learned historian, who enjoyed considerable authority in England, a racially 'impeccable' Aryan of eminently Nordic physiognomy, and his aesthetic-national views - especially the claim that art must be rooted in local culture - were fully acceptable to the Nazis. What was at work here was the same mechanism of trust and admiration for the German tradition as in Poland. The composer was impressed that a country which most English musicians saw as the artistic 'promised land' presented him with a prize. On the other hand, he was aware that contemporary Germany did not represent the same culture as in the past, which is evident from his letter addressed to the authorities of the University of Hamburg:

“...I feel bound to explain that I am strongly opposed to the present system of government in Germany, especially with regard to its treatment of artists and scholars. I belong to more than one English society whose [objective] is to combat all that the present German regime stands for... I cannot accept this great honour without satisfying my own conscience that I shall not feel in any way hampered in the free expression of my own opinion in accepting it." 316

Naturally, the German side assured the composer that the award had no political undertones whatsoever. The argument that eventually convinced the sceptical Englishman was that the prize was proof of a great change in the Germans' attitude toward English music in comparison with the 19th century. Tactfully enough, they did not refer in this context to Hanslick's famous contemptuous description of England as a "Land ohne Musik." Eventually Vaughan Williams accepted the prize and travelled to Hamburg in the summer of 1938 for its presentation. In the meantime, the artistic exchange between the two 'sister Germanic countries' was developing fast and also attracted lively interest in Poland. In January 1936 the bimonthly "Muzyka Polska" was informed in a report from London about a visit of critics representing Germany's leading music periodicals - the "Neues Musikblatt" and "Berliner Tagesblatt" - to the British metropolis, where they came to familiarise themselves "with the music life of that city and with trends in London criticism." The Polish correspondent stressed the German guests' "admiration for the abundance and good organisation of London's musical life, and for the level of the audience's music education. The English audience listens to concerts with the score in their hands; every third

316 Quoted after: Cobbe, "Vaughan Williams, Germany”, p. 92. More on the composer's internal conflict between admiration for the German music tradition and a realistic assessment of Nazi excesses can be read in: U. Vaughan Williams, Ralph Vaughan Williams., pp. 217 and 221. 
listener comes to the performance with the score." 317 The wide social scope of London's concert life was also noted and praised; this was made possible, the correspondent emphasised, by relatively low ticket prices. Naturally, the greatest interest was inspired by the exchange of excellent orchestras and by mutual presentation of works from the two countries. Thus, Dresden Opera's spectacles at London's Covent Garden ${ }^{318}$ and the London Symphony Orchestra's German tour under Thomas Beecham were widely reported, and the press dedicated much space especially to the ceremony of bestowing Britain's highest musical honour the Gold Medal of the Royal Philharmonic Society - to Richard Strauss, on the occasion of his visit to London with Dresden Opera's ensembles ${ }^{319}$. A series of British music concerts featuring works by Vaughan Williams, Elgar, Bliss, and others, were held in the main German music centres, while Berlin itself hosted in 1936 the premiere of Symphony No. 1 by the then rising star of English music - William Walton. This composition, one of the most significant British compositions of the interwar period, was favourably received by the German audience, which enjoyed the energy and vitality of the music as well as the evident continuation of the 'sound' Nordic stylistic trend mapped out by Sibelius. The Germans also clearly liked Walton's appearance (tall, blue-eyed and blondhaired). However, more and more British musicians were expressing their disgust and indignation at the pompous Nazi propaganda that accompanied these concerts. Ribbentrop, on the other hand, was disappointed by the distance with which the British authorities approached the programme - they seemed not to understand that it was not meant to be all just about music. Eventually the exchange was discontinued early in 1939. Already in January an anonymous correspondent of "Muzyka" magazine informed Polish readers that the London concerts of the Berliner Philharmoniker under Furtwangler had been cancelled, largely, as he claims, due to the unfavourable political climate, especially "the English society's attitude toward Germany." ${ }^{320}$ Still, according to Eric Levi, the direct cause of this cancellation was the reaction of British musicians, who were astonished by the reaction of German organisers of a choral festival, vetoing the main feature of the BBC Choir's programme - the works of... Vaughan Williams. It had turned out that the composer's criticism of the Nazi regime led to a ban on

317 (anon.), “Ze świata” (World News), Muzyka Polska, January 1936, p. 78.

318 (anon.), “Ze świata” (World News), “Muzyka Polska”, March 1936, p. 305.

319 (anon). "Ze świata” (World News), “Muzyka Polska”, May 1936, p. 428.

320 (anon). "Kronika” [Chronicle], "Muzyka" 1939 No. 1. p. 53. 
performing his music in the German territory ${ }^{321}$. The indignant Britons seemed to realise only now who really controlled the direction of this exchange - and consequently they boycotted the concert. We do not know how the composer himself reacted to this dishonour - or was it a 'distinction' for him? This dignified gentleman, brought up to respect freedom of speech as well as all kinds of 'gentlemen's agreements' - certainly had to accept, like the then British Prime Minister, that in the new political style agreements were entered into only to be broken at a later date whenever such a move could bring a political payoff.

Of the British periodicals in the 1930s, "The Monthly Musical Record" was distinguished by a consistently critical attitude toward Nazi ideology. It attacked particularly sharply the racial purges among German musicians. As early as in May 1933 the magazine's Notes of the Day informed about the dismissal of Bruno Walter and Otto Klemperer, who lost their posts not because of any artistic imperfections but due to ethno-political reasons in Chamberlain's spirit (naturally, this phrase refers to Houston Stewart Chamberlain). At this point, the editors reminded their readers of the ideological sources of racism and unequivocally condemned the decision as a case of "crude anti-Semitism," which must cause indignation in terms of music values and of decent, civilised liberalism. ${ }^{322}$

Naturally, qualifying these dismissals as "crude anti-Semitism," though well justified by the values quoted by the editors, shows that they could not imagine the real scale of crudeness and brutality still to come. Equally unimaginable at that time was the idea that high government and party officials who seized monopolistic power in a state boasting such an enormous cultural heritage could themselves organise racial persecution instead of preventing it. This is what most likely happened in the autumn of 1938 during the famous Kristallnacht - a demonstration of racist violence and brutality unprecedented in modern European history. As had happened many times before in history, artists - mainly writers and film-makers, but also politically and socially sensitive music composers - warned society of these social and political atrocities, which were unimaginable for people thinking in 'honest and civilised, liberal' categories. In the interwar period, British culture abounded in such artistic manifestos and prophetic, ominous visions, most of which came from artists of the younger generation, strongly involved in social drama and unwilling to isolate

321 Ursula Vaughan Williams writes (op. cit., p. 218) that this ban was imposed in February 1939. Cf. also E. Levi, Appeasing Hitler? p. 36.

322 From an anonymous commentary in: “The Monthly Musical Record”, LXIII, May 1933 , p. 78. 
themselves in variously conceived 'ivory towers'. It was also here, in the British Isles more than anywhere else, that novels, plays and compositions were inspired by the 'great politics', by the growing aggression of totalitarian states, the effects of putting racial doctrines into practice, which - possibly 'harmless' in the closed world of academic speculations - once they became part of everyday social and political reality, led to violence on a mass scale. It was this organised violence in international and domestic policies that progressively destabilised the European order and led to war. Fear of war was this generation's defining experience, which is why the youth in Great Britain at that time were particularly uniform with respect to ideology, their identity being defined by pacifism.

\section{The Ideological Counter-Offensive of British Great War Generation Artists - Pacifism against Racism and Chauvinism}

Pacifism was extremely popular among the young French and British intelligentsia in the 1930s. Pacifism was the exact opposite of totalitarian ideologies. Terror on a massive scale, the gradual militarisation of societies, which was justified either by struggle with a 'class enemy', or, as in the case of Mussolini ${ }^{323}$, by preparations for war, or as a 'natural' state that made the nation strong - all this was based on the glorification of, or acceptance for, organised violence. Pacifism rejected violence. It opposed social Darwinism and other historiosophic doctrines which saw 'struggle' (class or racial struggle) as the propelling force of history - with Christian and Buddhist ideas, as well as the Anglo-American philosophy of pragmatism and common sense. What, they asked, was the point of war as an instrument of international policy, when modern technology made it possible to destroy completely a large part of the continent and cause the collapse of human civilisation?

As we know, pacifism became widespread after World War I mainly in the victorious societies of those countries that imposed the Treaty of Versailles on the world, and were therefore not interested in changing the status quo. Pacifism was especially popular in England, in the generation born and brought up - as Samuel Hynes put it ${ }^{324}$ - in the shadow of the Great War. The shock of that war determined the psychic makeup of the entire generation. The atmosphere of that

323 Cf.: H. Kohn, “The Totalitarian Philosophy of War”, in: Reflections on Modern History, (Princeton: The Van Nostrand Company, 1963), p. 216.

324 Hynes, The Auden Generation, pp. 17-39. 
time and the qualities that shaped the generation's identity are faithfully reflected by the writings of its most eminent representatives: Auden, Upward, Isherwood, and Orwell. According to Hynes, these authors, brought up in the cult of heroic deeds and of heroic death for the king and the country - already as very young people they saw the glaring discrepancy between these idealised visions and the grim reality of the frontline as described by returning soldiers, many of whom were physically or mentally crippled by the experience. The generation soon found its own voice - Wilfried Owen, a 25-year-old poet and pacifist, who perished on the eve of a truce and whose pointless death became a symbol. The economical, nearly journalistic style of his poems was a revelation for them. Owen showed the war as it really was, in brutally drastic visions, but also making use of ironic paraphrases of Biblical stories ${ }^{325}$. It was apparently mainly to Owen that the British "Great War" generation owed its tendency to take up a moralising mission based on a reinterpretation of modernised Christian parables. This was related to the crisis and chaos in moral values and to attempts to understand the powers that govern contemporary society - attempts which resulted in literary visions of monstrous dystopian states. The first of these can be found in Upward and Isherwood's early Mortmere stories, set in a fantastic city where all the moral norms are turned upside down. Orwell's 1984, written after World War II, was a late version of such a dystopia.

The awareness that the 1930s were in fact a period in-between world wars began to take shape already in 1930. The first literary visions of the imminent catastrophe appeared in that very year, while after 1935 we have an impressive number of books dedicated to the future war, beginning with Evelyn Vaugh's novel Vile Bodies, which contains an interesting analysis of the origins of contemporary conflicts:

\footnotetext{
"Wars don't start nowadays because people want them. We long for peace, and fill our newspapers with conferences about disarmament and arbitration, but there is a radical instability in our whole world-order, and soon we shall all be walking into the jaws of destruction again, protesting our pacific intentions..."326
}

325 This paraphrase of the Biblical tale of Abraham and Isaac - characteristic of Owen, and later also of Benjamin Britten - is an accusation of hypocrisy levelled at the "old men" deemed responsible for the outbreak of the war. Abraham disobeyed the God he worships, and who commands him to sacrifice his pride. His thirst for blood makes him murder his own son and later "a half seed of Europe, one by one..."

326 Quoted after: Hynes, The Auden Generation, p. 61. 
The pacifist worldview was very widespread in British society during that period. G. M. Trevelyan writes:

"The English people, in a natural reaction after four years' experience of the unspeakable horrors of modern 'total' war, regarded pacifism and unilateral disarmament as a method of securing peace, and hailed the League of Nations as a machine for making all safe by some magic or automatic process not clearly defined."327

In 1933 the Oxford Union voted that they would not fight "for the King and the Country." In this way, they made it clear that in pacifism there was no distinction between aggressive and defensive war, because both were viewed as a crime ${ }^{328}$. A powerful pacifist faction, the Peace Pledge Union, active in the 1930s, received support from a public poll called the Peace Ballot, in which nearly twelve million citizens took part (1935). This situation could not remain without influence on the foreign policies of Neville Chamberlain's government - and Hitler eagerly took advantage of the public climate in the British Isles. Noble as the young British elite's motives undoubtedly were, that elite did not yet realise that it was playing into the hands of their future mortal enemy. By combatting the national armaments programme, the Great War generation contributed to the weakness of the main European empire that could defend liberal and democratic values. In this way, it determined its own tragic fate, and that of the whole of Europe - the same fate that it strove to avoid at any cost.

In music, the main exponents of the dominant pacifist ideology of this generation were Great Britain's two most eminent 20th-century composers: Michael Tippett (1905-1998) and Benjamin Britten (1913-1976).

\section{8 - The Breakthrough Year: Benjamin Britten's and Michael Tippett's Politically Involved Works in Relation to Events in the Third Reich}

When we compare the biographies of Benjamin Britten and Michael Tippett, we cannot fail to note some striking parallels in their aesthetic and political views,

327 George M. Trevelyan, A Shortened History of England, (Harmondsworth: Penguin Books Ltd, 1981), p. 558.

328 According, to English historian A.J.P. Taylor, this was a gesture of support for world peace rather than disloyalty toward one's own country. In that historical moment, the only kind of threat envisaged was still imperialistic-colonial war and the citizens of the world's empires - Great Britain included - united in such gestures in order to 'watch carefully' the policies of their own governments. Cf. Alan J.P. Taylor, English History 1914-1945, (Oxford: Oxford University Press, 1982), pp. 448-449. 
as well as their life histories. These similarities result largely from their strong generational identity. They were both born into prosperous middle class families and brought up in highly cultured environments. They received a very good general and musical education; both graduated from London's Royal College of Music. Their careers took different courses. Tippett lived much longer and fully manifested his talent only after his younger colleague's death. On the other hand, Britten's international position as a leading 20th-century classic still seems to outshine Tippett, though the latter's amazing late-maturing talent is now gaining more and more recognition, catching up with Britten's fame. In the early 1930s, both composers exhibited interest in the social-political context of art's function that was typical of their generation. Both perceived their own work through the prism of an aesthetic developed by a leading art ideologist who influenced their generation's dominant literary circles - namely, Wystan Hugh Auden. The key aspect of his aesthetic was a sense of social mission and the incorporation of a vast array of artistic tools from various disciplines for the purpose of actively supporting society's ethical education. Auden was convinced that apart from the attempt to use art to escape from reality (escape-art), ${ }^{329}$ it is modern society's vital need to cultivate a parable-art ${ }^{330}$. In the 1930s, both Britten and Tippett demonstrated their solidarity with those social classes that had been most acutely affected by the Great Depression ${ }^{331}$, both resolutely opposed all forms of chauvinism and racism, and both declared themselves as fervent pacifists.

Pacifism agreed both with the two composers' personal sensitivity and with the fashion that was then universally adopted by young intellectuals. Already as a child, Britten demonstrated a great sensitivity to social injustice and persecution, an attitude that was most likely enhanced by his father's habit of reading Dickens's novels aloud to the family in the evenings when the artist was just a

329 Wystan H. Auden, "Psychology and Art To-day", in: G. Grigson (ed.), The Arts To-day, (London: Bodley Head, 1935), p.20.

330 Britten came under Auden's influence in 1933, as a 20-year-old, when he started his work for the GPO-Film Unit in London, a documentary film studio that attracted England's greatest literary, film-making and graphic talents of the generation. Most likely under the influence of Auden's group, Britten began to drift to the left in his political views, which was also fashionable among students of elitist British universities during that period.

331 In 1933-34 Tippett was involved in outreach musical activity at the North Yorkshire Work-Camps; in the same period he founded and directed the South London Orchestra - made up of unemployed musicians and based in a working-class district of London. 
few years old. At secondary school Benjamin Britten was known to defend the weak from being bullied by stronger pupils - a mission which he could successfully undertake thanks to his impressive physical fitness ${ }^{332}$. His sensitivity, supported by Christian beliefs and generational tendencies, transformed in the 1930s into an absolute type of pacifism, with a nearly fundamentalist colouring, which accepts no exceptions to the commandment of "Thou Shalt Not Kill" and condemns every kind of violence, claiming that no state or social organisation can usurp the right to justify the use of violence.

Tippett's road to pacifism was more complicated, marked by internal conflicts related to his involvement in the communist movement and his fascination with Jung's theories. In 1935 Tippett joined the Communist Party of Great Britain, but as a follower of Trotsky and an opponent of Stalin, he soon left the party. Besides, the theory of class struggle and the cult of revolution were at odds with the pacifist repudiation of violence. Eventually Tippett chose pacifism and a more socialist worldview, while Jung's concepts of self-awareness and the balance of opposites allowed him to distance himself from the contradictions of his own nature ${ }^{333}$, as well as propose an interpretation of the subconscious motives of racist behaviour.

Britten was the first to react to racist acts of violence in his art. His song cycle Our Hunting Fathers for soprano and orchestra, to a text by W.H. Auden (1936), is a loud accusation of the well-to-do elite's thoughtless cruelty evident in hunting as kind of primitive atavism. But the cycle also presents parallels to similarly cruel hunts already organised at that time in Germany, in which human beings were considered as game. As Donald Mitchell observes ${ }^{334}$, the juxtaposition of the words "German, Jew" in the text of Britten's song about the hunt cannot be found in Auden's original and is therefore the composer's own, evidently political initiative. However, for a full manifestation in music of the protest against totalitarian violence (racism included) one had to wait for the year 1938, when dramatic international tensions and the threat of war triggered such responses. Both Tippett and Britten then made use of the forces that seemed ideal for such an ideological mission - namely, those of a mixed choir.

332 Britten excelled in many sport disciplines: he was an excellent swimmer, captain of a football team, and famous for his 'hard fists'. Unfortunately an inborn heart defect and being notoriously overworked led to his early death at the age of 63 .

333 Michael Tippett, Those Twentieth Century Blues: An Autobiography, (London: Hutchinson 1991).

334 Cf.: Donald Mitchell, Britten and Auden in the Thirties, (London: Faber and Faber, 1981), p. 48. 
Britten was the first to 'break the ice'. Alarmed by Germany's growing aggression on the outside (the Munich crisis) and inside the country (Kristallnacht - the 'Night of Broken Glass'), in the autumn of 1938 he completed his motet Advance Democracy for a capella choir to a text by Randall Swingler, editor of the leftist journal Left Review. The generic attribution of this work most likely results from the prominent role of counterpoint, from the relation between text and music, and the role of rhythm in the dramatic structure of the piece. These elements look back to both the concept of the medieval motet as derived from the French le mot ('the word'), and from the Latin motus ('movement'). The composition, made up of two strongly contrasted parts, opens with a sombre vision of urban blackout, where the night darkness is torn by cold anti-aircraft searchlights. The choir's hushed voices perfectly reflect the mood of anxiety, at times even of paralysing fear. The choir is divided into two groups; the female voices intone a kind of disturbingly monotonous cantus firmus vocalise, moving upward and downward in turns, on the foundation of alternating broken chords of $\mathrm{C}$ minor and $\mathrm{G}$ minor (modally speaking, minor tonic and minor dominant). Against this background we hear a march melody sung by male voices, made up of short, punctuated, staccato articulated 'cries', each 'cry' corresponding to a single text syllable. The text informs us of warnings and threatening news that fill newspaper headlines, of anxious speculations concerning such news, people whispering at the table or talking behind closed doors. Tension gradually grows, enhanced by a change of texture; the 'moaning' cantus firmus is taken over by the male voices, while the female ones take up the march-like declamatory melody. The music now moves into the key of $\mathrm{G}$ minor. As the tension further escalates, the exchange of voices becomes faster, and the pendulum-like movement of the cantus firmus grows wider in range. This animation of musical movement (though the dynamics still do not exceed piano - pianissimo) coincides with the appalling conclusion of this section; the price of the secret 'haggling' behind closed doors will be, as we hear, the 'people's doom. These words are followed by an aggressive crescendo that leads to another vision - openly exposing the brutality of the war machine swinging into action, the 'roar of war' in factories and the beat of thousands of marching feet, which drowns out all other voices and turns life in Europe into a nightmare. The march-like melody on these words is repeated with progressive downward shifts, which makes the impression of sound of marching troops fading away in the distance. Britten repeated these words and rhythms ${ }^{335}$ many

335 Importantly, such frequent mechanical repetitions were later used in Britten's opera Peter Grimes as an allusion to mindlessly repeated gossip - a dangerous mechanism 
times, clearly aware of the fact that march rhythms are the best symbol of militarism in sound, also purposefully applied as a way to appease people's conscience and steer the minds of individuals in totalitarian countries ${ }^{336}$. The main culmination of the piece leads to the somber reflection that the sun of safety and stability was setting for Europe, and the continent plunged in the shadow of dictatorships. We hear a rhetorical question: Can nothing save our freedom? Will our lives be reduced to dust?

The second part of the composition does provide an answer. As the minor keys give way to major ones, fear and uncertainty are replaced by joyous optimism. The passage-based cantus firmus, previously presented as a symbol of fear and threat, is transformed into a nearly victorious hymn. After the minor-tomajor transformation and all the voices joining forces in octaves and in unison, it becomes a symbol of social unity, while the expansive ascending movement illustrates the text's call to action. It is time for democracies to rise, to shake off passive apathy and begin to speak with one voice, so that the values that our fathers fought for were not annihilated. Swingler and Britten left the audience in no doubt as to what kind of struggle they had in mind. Though the words about reviving pride might suggest a reference to the demand (more and more popular, especially among the lower social classes in the British Isles) to show that the proud lion of Britain can still roar and oppose Hitler's aggression, from another section of the text we learn that it was also time... to disband army divisions.

The events of 1938 meant that the numbers of British pacifists began to dwindle with lightning speed. Still, orthodox followers of this doctrine, Britten included, remained resolute in their views. If we unilaterally disarm ourselves, others will follow. Why should any state spend enormous sums on the army if

in the collective psychology of totalitarian countries. An identical musical tool was used in the famous march from Symphony No. 7 'Leningrad' by Shostakovich, with whom Britten demonstrates spiritual and aesthetic affinities.

336 Thanks to (mainly American) journalists and diplomats, the West was already aware at that time that Nazi para-military organisations were responsible for the most brutal assaults of the Kristallnacht. Britten was right in his intuitive association of the Munich crisis with the events of that night. This is confirmed by Hermann Göring's frank statement at a meeting of the top authorities of the Third Reich on 14th November 1938: "If the Reich becomes involved in some international conflict in the nearest period, it is obvious, that also in Germany we will consider, first and foremost, how to settle all our accounts with the Jews.” Quoted after: Karol Jonca, „Noc kryształowa“ $i$ casus Herschela Grynszpana [Kristallnacht and the Case of Herschel Grynszpan], (Wrocław: Wydawnictwo Uniwersytetu Wrocławskiego 1998), p. 12. 
there is no threat from the outside? If this fails, however, and we are attacked, the only solution will be to refrain from armed resistance. This universal gesture of 'turning the other cheek' will take the wind out of the sails of even the most aggressive dictators. In the longer run, it will lead them to their fall.

Admittedly there was some kind of logic in this reasoning, but it the political situation of that time, it was naïve and dangerous. Naturally, there is no point in starting a polemic with these views now, with reference to the 1930s, and formulate conjectures as to what would have happened, had the democratic countries really 'disbanded their divisions', how the Nazis would have treated those nations which they classified as Untermenschen. Artists are often dreamers, but they can also prove to be visionaries. Britten had his idea - and though in the autumn of 1938 he must already have realised the inevitability of war $^{337}$, he still believed that this idea ought to be propagated, just as ethical norms must be followed regardless of circumstances. It was all about saving the dignity of humankind in a world in which violence would become an everyday experience for millions of people.

While Britten opened his series of pacifist manifestos with small and mediumscale musical genres, in order to pass on to great vocal-instrumental and operatic forms after the war, Tippett started directly with a great form and the largest performing forces available. His artistic response to the terrifying events of 1938 took the form of a huge oratorio entitled A Child of Our Time, for four soloists, two choirs and large orchestra. Inspired by the first mass Nazi pogrom of the Jews before the outbreak of the war - the Kristallnacht of November 1938, conceived as an act of revenge for the assassination of a German diplomat in Paris by a desperate 17-year-old Polish Jew - Herszel Grynszpan. Kristallnacht, which exposed the true face of Hitlerism, was a shock to European public opinion and largely contributed to a political 'sobering' of the silent admirers of the Third Reich in the West.

Notably, the whole tragedy began with a directive from Polish authorities which deprived émigrés of Polish citizenship if they had lived abroad for many years and did not maintain contacts with the mother country. This also affected 11 thousand Polish Jews living in Germany, and the Nazis eagerly used this opportunity to deport the already 'stateless' Jews to the Polish border, seizing

337 Soon after Chamberlain's return from Munich with his famous 'piece of paper' that was to guarantee peace in Europe, Britten wrote rather ironically in a letter to his editor that he was going to celebrate this event 'with berry picking', in the hope that there still would be some 'next year' when he can eat the jam made of those berries... Cf. Humphrey Carpenter, Benjamin Britten. A Biography, (London: Faber and Faber, 1992), p. 123. 
all their possessions. This was not the end of their drama. Since they had no Polish passports, the Polish authorities refused entry, thus sentencing the Jews to narrow vegetation in the border strip ${ }^{338}$. Among those who found themselves in this situation was the Grynszpan family, who had resided for many years in Hanover, running a tailor's workshop. They wrote a desperate letter to their son in Paris, hoping that Herszel might save them from this oppression and arrange for emigration to America - which was obviously a very unrealistic expectation. Herszel himself was an illegal alien in France and could not find steady employment; to make matters worse, his French was also poor. He lived with an uncle, took up casual jobs and also feared deportation. A US visa was completely beyond his reach. Feeling like a hunted animal, Herszel came to the German embassy on 7th November 1938, armed with a revolver, and demanded meeting with some higher official, on the pretext that he had important information to impart. In was early morning and the only higher official on duty was Ernst vom Rath, secretary of the embassy. Grynszpan was led into his room. Without saying a word, he took out a gun and shot three times at the terrified diplomat. Mortally wounded, vom Rath soon died in hospital despite energetic intervention of French and German physicians. Grynszpan voluntarily gave himself up to the police, and announced that his deed was an act of desperation and vengeance for the persecution of his compatriots. This statement was printed on the front pages in the press.

This assassination was precisely what the Nazis needed. Admittedly, vom Rath was not a member of their party and was even suspected of a lack of enthusiasm for national socialism. But this was no obstacle for the Nazis, who now had 'proof' of their theory concerning an international Jewish conspiracy against the Third Reich, and could launch the long-planned persecution. Goebbels was euphoric. He immediately travelled to Munich, where an assembly of the Nazi revolution

338 This is how the Western press frequently presented the situation, as did the British studies to which Tippett had access. For instance, Mosley wrote about thousands of homeless people facing the harsh 'Polish winter'. Some of the German sources, however, paint a much less dramatic picture, claiming that the hapless exiles' misery on the border did not take long, because in just several days the German and Polish authorities reached an agreement and the deportations stopped. We know that the Jews camping by the border near Zbąszyń were taken care of by the Polish Red Cross and Polish-Jewish organisations. The Polish state and local authorities took action as well, creating transition camps in the cities of Wielkopolska, and directing the sick to a hospital in Poznań, while children were placed in children's homes. Cf. Jonca, Noc kryształowa, pp. 101-102. 
veterans was just taking place. The following evening, hell was unleashed on Jews throughout Germany ${ }^{339}$.

These, then, were the events that Tippett used as the point of departure for his composition. The composer first addressed T. S. Eliot, a leading British writer of the time, to write the libretto, but the latter refused, fearing that his text might dominate the whole work. Knowing Tippett's own literary talent, he advised the composer to write the libretto himself. The text does not focus on the specific historical events; the composer uses them as a vehicle for a universal message, providing them with a psychological and philosophical context, with evident influences from the theories of C.G. Jung, while the simple and succinct style of the libretto brings to mind the writings of the aforementioned Wilfried Owen. From the formal-musical point of view, Tippett modelled his work on the oratorios of Bach and Handel, particularly on the Messiah. The tripartite composition is divided into traditional numbers: solo and ensemble sections (ensembles of soloists), interludes and choruses.

It is the choruses that play a crucial role here. Apart from ensemble scenes important for the progress of the action, and in which choruses symbolise antagonistic social forces (such as the Double Chorus of Persecutors and Persecuted) and apart from the traditional role of the chorus as a moralising commentator, Tippett also makes use of the original (though controversial) idea of summing up large sections of dramatic action by means of African-American spirituals, which make use of the joint forces of both choirs and the soloists. According to the composer, their function is analogical to that of the Protestant chorales in oratorios by J.S. Bach - they are the 'voice of the people' as well as providing a timeless, universal commentary. The choruses also have an extra-musical significance in the form of a global cultural, anti-racist message. In order to reconcile such distant forms of musical language - the spirituals, based on major-minor harmonies and the oratorio itself, with its complex contrapuntal lines and frequent strongly chromatic textures - Tippett used as an integrating component the interval of a minor third, which plays a crucial role in the selected spirituals, as well as in those sections of the work which contain enclaves of tonality (almost exclusively minor chords). The minor thirds also largely structure the motifs in those sections where linear chromatic progressions are presented without a tonal context.

The reflective first part opens with a melancholy, still very Romanticsounding orchestral introduction, after which the hushed voices of the choir

339 Cf. Jonca, "Noc kryształowa". 
announce that "The world turns on its dark side. It is winter." Philosophical questions follow: Can evil be good? Can human reason be wrong? The alto responds: "Reason is true to itself. But pity breaks open the heart." The choir's conclusions are alarming: "We are lost. We are as seed before the wind. We are carried to a great slaughter." This pessimistic reflection leads to a picture of 'our times' presented by the narrator (bass), dominated by persecutions both in the East and West. The Chorus of Persecuted asks when hunger is going to disappear from fertile lands, when the rule of usury and avarice ends in the cities? After this exchange of ideas and questions, we hear the voice of the protagonist (tenor), who depicts his desperate situation. He is still almost a child. "I have no money for my bread, I have no gift for my love. I am caught between my desires and their frustrations as between the hammer and the anvil." Then he asks another rhetorical question: "How can I grow to a man's stature?" The soprano echoes his anxieties: "How can I cherish my man in such days, or become a mother in a world of destruction?" The tension accumulating with the successive questions, to which no answers are provided, is relieved by the first spiritual, which ends the opening part of the oratorio. Everybody sings "Steal away to Jesus," as if to suggest that Jesus is the only light of hope in the face of overwhelming darkness caused by the global escalation of violence.

Part two tells the story of a young man who seeks justice in vain. The hushed melancholy lyricism gives way here to aggressive dynamism, while the tempi accelerate. The choir announces: "A star rises in mid-winter. Behold the man! The scape-goat! The child of our time." The narrator reports in a nearly evangelical language: "And a time came when in the continual persecution one race stood for all." The aggressive Double Chorus of Persecutors and Persecuted exchanges shouts that musically represent the vicious circle of hate in which society has lost its way. The Chorus of the Self-righteous shouts: "We cannot have them in our Empire. They shall not work, nor draw a dole. Let them starve in No-Man's Land!" The narrator retells the successive events that lead to the culmination. The persecuted young man is overcome by fury: "His other self rises in him, demonic and destructive. (...) He shoots the official," and the alto adds "But he shoots only his dark brother - And see...he is dead." This second part, abounding in movement and brutality, ends with a negro spiritual that recalls the fate of the Israelites in Egypt (Go Down Moses), thus suggesting a distinct parallel between the fate of the persecuted Europeans and that of the African American population. The finale brings a strong pacifist message: one cannot fight violence with violence. Good and evil, light and darkness, reside in every one of us. They need to be recognised and controlled. The final ensemble scene brings these significant words: "I would know my shadow and my light, so shall I at last be whole." 
This conclusion, derived from Jung's concept of self-awareness and the balance of opposites, proved crucial to the later development of the composer's aesthetic and ethical views. It also offers a key to understanding Tippett's pacifism.

The oratorio A Child of Our Time, written in the shadow of the dramatic events of 1938-41, was only premiered in 1944 and constituted a breakthrough in Tippett's career as a composer. It brought him fame and reinforced his position in his own country. Meanwhile the young assassin's deed was condemned immediately and as emphatically as possible - by both German and international Jewish organisations, who knew all too well that the event was extremely convenient for the Nazis in their policies ${ }^{340}$. What, then, happened to the ill-starred 'child of our time'?

Grynszpan's later fates could well serve as a scenario for an action movie ${ }^{341}$. The German authorities demanded that France should hand over the assassin, but the French refused, on the grounds that he was not a German citizen, and the crime was committed in French territory, which is where the culprit must be tried. In the meantime, the case was much publicised in the media, which motivated anti-Nazi journalists to attempt a defence of the young assassin. A prominent role in this campaign was played by US journalist Dorothy Thomson, expelled from Germany for her views in 1934. Thomson's thesis was that the real culprit was Germany and its anti-Jewish policies. She created an international fund for Grynszpan's defence and soon raised several thousand dollars. At the same time, she appealed to the Jewish communities not to contribute to the fund lest they should be accused of taking part in a conspiracy - especially since the Nazis threatened the Jews with another pogrom in case any organised protests should be held. Grynszpan's defence at court was taken up by one of France's most eminent barristers, who immediately developed an 'apolitical' line of defence. According to the French law, the punishment for every political assassination, regardless of moral motives, was a death sentence, while if the deed was qualified as a crime of passion, the culprit could avoid the capital punishment. The lawyer took advantage of gossip concerning the victim's homosexual preferences and presented the whole situation as the tragic end of a homosexual affair, the consequence of a conflict between lovers. Nevertheless, as French-German relations

340 Among the many speculations that appeared in the context of the assassination, some even claimed that Grynszpan worked for (or possibly was blackmailed by) the Gestapo. What is undoubtable is that it was Goebbels and Himmler in their two politicalempires' that profited most from the consequences of this act.

341 Such a film, entitled Livrez-nous Grynszpan, directed by Joel Calmettes, was actually made in France in 2008. 
were deteriorating, the prosecutor delayed preparing the indictment until the Third Reich's attack on France. The convoy in which Grynszpan and other prisoners were transported south was bombed. Some of the cars were hit and many of the prisoners perished, but Herszel and the remaining ones managed to escape. However, he voluntarily gave himself up to the police, presumably feeling that prison was the safest place for him. What he did not foresee was the fall of France. He soon found himself in the hands of the Gestapo and was transported to Berlin, where - paradoxically - he was not tortured or anything, because on Goebbels's orders he was to await a show trial. The latter was postponed all the time, since the German judiciary could not find the right legal clause to start a trial in Germany - for the same reason why France refused to hand Grynszpan over to the Nazis. What is more, the Germans now had the documentation prepared by the French defence and feared that revealing vom Rath's homosexuality, if publicly confirmed by Grynszpan, might compromise the Germans. In the end, the trial was never held. Grynszpan was transported to some camp deep in Germany, and was never heard from after that. 



\section{The Italian "National Awakening" and Historical-Imperial Nationalism. Art in the Context of the Fascist Myth of Romanità}

In December 1925 Roman Dmowski argued: "If we [Poles] were similar to today's Italy, if we were so well organised as the fascists and had Mussolini, who is undoubtedly the greatest man in present-day Europe - we would not need anything else..." ${ }^{342}$ Today Dmowski's claims may seem outrageous, but from the perspective of that time, Mussolini's achievements were viewed positively by many people in Europe. From the time of the famous march on Rome, Italy changed significantly, and though the price of political stability and economic progress was the gradual limitation of civil rights and brutal treatment of political opponents - in the international scene the dominant opinion was that expressed by Ray Moseley:

"Mussolini had instituted ambitious public works projects, set up a social security system, drained the Pontine Marshes, preserved the monuments of ancient Rome, and made the trains run on time. He was bringing order and discipline to Italy, compelling his countrymen to abandon their languorous Latin way of life and become part of modern Europe." ${ }^{343}$

It is difficult to judge whether Dmowski (who wrote these words in 1925, the time of another political crisis in Poland) was aware that "undoubtedly the greatest man in present-day Europe" was transforming Italy, politically and institutionally, into a totalitarian state. In 1934, when the Nazis introduced a state organisation modelled on the Italian fascists, Dmowski (as we explained before) was critical of this form of government. The Polish press of the 1930s also wrote critically (sometimes even caustically) about the inflated bureaucratic structures of the fascist state responsible for artistic patronage - one might think that "administering art is as important as art itself." Nevertheless, the prevalent tone in both the nationalist and the government-supported press was favourable toward Italy, its cultural achievements and the traditionally pro-Polish attitudes

342 Quoted after: Wapiński, Historia, p. 204.

343 Ray Moseley, Mussolini's Shadow. The Double Life of Count Galeazzo Ciano, Yale University Press 1999, Chapter One, available at: http://www.worldcat.org/wcpa/ servlet/DCARead?standardNo=0300079176\&standardNoType $=1 \&$ excerpt $=$ true, accessed 3.10.2018. 
of Italians. This sentiment was reciprocated by the Italian side despite the fact that in the late 1930s, the two countries found themselves in opposite political and military camps.

The history of Polish-Italian relations can indeed serve as a model example of how cultural factors and traditional mutual friendship dominated over shortlived political alliances. In an issue of the Warsaw-based social-literary weekly "Prosto $\mathrm{z}$ mostu" published just 10 days before the outbreak of the war, we find an extensive article by Adolf Nowaczyński ${ }^{344}$, who sums up the Polish-Italian relations to date. The author recalls the memory (still vivid in Italy) of the military actions of Mickiewicz's famous legion, which fought at the side of Garibaldi, as well as forgotten examples (worthy of a heroic film) of Italian volunteers taking part in the January Uprising of 1863/64 in Poland. He also quotes impressive numbers of translations of works by the greatest Polish writers into Italian, and observes: "When we examine the Italians' unusual liking for the remote, Hyperborean Poland and Poles in the 19th century (with no parallels among any other nations), there is one field in which our research and explorations yield truly phenomenal results." That field is that of opera, which, as Nowaczyński explains, was "the most popular, most favourite discipline of the arts, through which the eternal genius of that immortal nation expressed itself just as fully and perfectly as in architecture, the plastic arts and in painting." Nowaczyński stresses the fundamental importance of the Italian opera for the entire progress of European culture and notes that:

"No European nation's history has been explored so frequently and constantly as... Polish history. Not only authors of Polish operas, but even Polish playwrights have not explored their own history as often as it was done by the Italian composers, including such world-famous composers as Cherubini, Rossini, Donizetti, Ponchielli, and Verdi!"

Examples from 20th-century history quoted by Nowaczyński are even more telling. In 1916 a group of 70 Italian MPs and senators was the first in Europe to present a resolution demanding the restoration of the Polish state. In 1923 the Italian government was the first to recognise Poland's eastern borders, and a year later granted Poland the first 'stabilisation loan'. In 1931 Mussolini spoke enthusiastically about Poland's achievements. In 1938 Beck, the Polish Minister of Foreign Affairs, visited Rome, and the following year his Italian counterpart, count Ciano, came to Warsaw. "Can 1940 change all this?” asked Nowaczyński rhetorically.

344 Adolf Nowaczyński, "Italia i Polonia” [Italia and Polonia], Prosto z mostu, No. 34, 20th August 1939, p. 8. 
Naturally, many more examples could be added to Nowaczyński's list, and the colourful history of the Polish-Italian friendship deserves a separate monograph. What is interesting for us in the specific context of this book is that this history exemplifies similar parallel developments of nationalisms determined by similar historical conditions (in the case of 19th-century Poland and Italy - the struggle for state independence), lack of mutual conflicts, fascination with cultural and climatic-geographic differences, as well as the idealisation of past successes and of historical forms of statehood. As we know, the political elites of interwar Poland had superpower aspirations and eagerly referred in this context to the historical heritage of the (pre-19th-century) Polish Lithuanian-Commonwealth, which many Poles greeted with undisguised approval. Italy had much greater ambitions in this respect, proportional, one could say, to the ancient legacy which fascists appropriated and turned into their state's strategic aim (as well as the source of national fame). Fascist Italy was supposed to become not only an heir to the great Roman Empire, but its revived modern equivalent in the contemporary global context. It was the mission of fascism to return to Italy's imperial roots and link the remote but glorious past to an idealised future in which ethnic nationalism of the italianita type could transform into an imperial romanita. The fascists aimed to kindle national aspirations and convince their compatriots that with such roots (which other contemporary political powers could hardly match), Italy could well regain a place among the world's greatest empires. The very etymology of the term fascismo, which derives from fascio littorio - a bundle of rods tied around an axe, also used in the national emblem of the fascist state - referred to ancient Roman traditions, as also did the restored Roman salute with the raised, extended right hand, references to Roman eagles, triumphal arches, colonnades and other Roman elements that dominated new Italian architecture and cityscapes, exerting on the mass imagination an impact comparable to that of commercials ${ }^{345}$

Naturally, the dream of reviving the empire required an enormous civilizational and technical leap, the point of departure for which was the general modernisation of all aspects of life, and especially those that could transform

345 Laura Malvano, Fascismo e politica dell'immagine, (Torino: Bollati Boringhieri, 1988), pp. 152-153. The author stresses the role of visual messages in the fascist propaganda of the romanità myth. Visuals had a decisive influence on the hermeneutics of Romanity' on the mass scale. Of key importance was the intensity and frequency with which all the fasci, eagles and other Roman attributes were exhibited in public space, which worked on the fundamental level of perception. Cf. also: Andrea Giardina "The Fascist Myth of Romanity", Estudos Avancados 22(62), 2008, pp. 55-76. 
the nation's mentality in the way desired by the now all-powerful state. The corporation system imposed by the regime was to ensure the solidarity of all social groups and eventually impose national homogeneity. As Mussolini himself put it (or the neo-Heglist Giovanni Gentile, fascism's main ideologist, who inspired Mussolini's writings):

"for a fascist everything is contained in the state. There is nothing human or spiritual outside the state (...) Fascism is totalitarian in this sense, and the fascist state, as a synthesis and unification of all values, gives meaning to the entire life of the nation..."346

The total submission of all the population to a strictly centralised authority was to facilitate the planned 'civilizational leap' and diminish the huge contrast between the well-developed North and the backward South. The regime believed that only military-style organisation could release the enormous energy necessary to achieve the expected transformation. Mussolini had no doubts that a fascist must be a man of action who, moreover, is "aware in a masculine way of the difficulties encountered" and ready "to face them in an equally masculine fashion." A fascist "scorns comfortable life" since he "views life as a struggle and believes that man must earn a life truly worthy of being a man..." ${ }^{347}$ Some foreign journalists suggested that this great national effort and the imposition of military discipline on the society carried the danger of making the individual in such a state feel weak, lacking subjectivity, annihilated in fact. But Mussolini, similar to most dictators, liked to draw on military discourse and metaphors, and he had no such fears. For him, each citizen was to the state what a soldier is to the army - and so, the strength and possibilities of each citizen were multiplied, not diminished, by the strength and possibilities of other soldiers in various army units ${ }^{348}$. Fascist propaganda associated Rome with three main attributes: power, discipline and modernity. It was the all-embracing discipline imposed by Mussolini on his compatriots that was to guarantee national success, improve Italy's position and be the key to achieving the correct level of modernisation.

346 Benito Mussolini, Doktryna faszyzmu [The Fascist Doctrine], transl. S. Gniadek, (Lwów: Filomata, 1935), p. 22. Importantly, this was one of many translations into European languages of the entry for Fascismo, printed in the Enciclopedia Italiana, Rome 1932. Though the Italian dictator was officially its author, it is believed to have actually been written by Giovanni Gentile and commissioned by Mussolini.

347 Mussolini, Doktryna, p. 19.

348 Quoted after: Kohn, The Totalitarian Philosophy of War, p. 222. 


\section{Modern Art or Degenerate Art? Modernism and Its National Aspects in Fascist and Nazi Ideologies}

Intense modernisation was necessary to transform Italy into a revived Roman Empire, which once was the ancient world's civilizational avant-garde, astonishing in the scale of its construction works (huge edifices, roads, aqueducts), inventions that were thousands of years ahead of their time (concrete, the steam turbine), traffic organisation and such transport devices as ancient 'taxis.' The regime's enthusiasm for modernity also translated into promoting the arts. Mussolini saw himself not only as a patron of the arts and a friend of artists, but actually as 'one of them', which he announced with his characteristic directness at the opening of the Gruppo dei Pittori del '900 graphic arts exhibition in Milan in March 1923, where he felt, he claimed, as "an artist among artists", because politics is an art; indeed, the highest of all arts, since its material is the hardest to wield and at the same time easiest to shape - "that material is man." 349

This statement, apart from being a metaphor of the fascist ambition to form a 'new man', also proves that the Duce - like Hitler - viewed himself as 'an artistic soul', though unlike Hitler, who focused on graphic arts and architecture, Mussolini - having made some literary attempts in his youth ${ }^{350}$ - believed himself to be, first and foremost, a musician. He would play the violin with his son Romano (later known as a fairly good jazz pianist). Raffaello de Rensis even wrote a book entitled Mussolini musicista ${ }^{351}$, where he extols the Duce's musical talents like a courtly flatterer, though he modestly admits that he had had, until that moment, no chance to hear Mussolini play. Naturally, Italy's artistic circles tried to take advantage of both the dictator's artistic sympathies and of his

349 Quoted after: Fernando Tempesti, Arte dell'talia fascista, (Milano: Feltrinelli, 1976), p. 59.

350 In 1909 the future dictator wrote a historical novel, published in English translation in 1928 by the New York publisher Albert and Charles Boni. Is title, The Cardinal's Mistress, seems to foreshadow Mussolini's future love of 'carnal pleasures', for which he was notoriously known...

351 Mantua: Edizioni Paladino, 1927. It is a 47-page brochure, richly illustrated with the dictator's photos, published in the propagandist series "Mussolinia", edited by Franco Paladino and dedicated to the promotion of Mussolini's cult. The series includes panegyrics praising the leader's activity in many disciplines of life, which was to demonstrate his versatile talents and largely foreshadowed the future cult of Stalin in the Soviet Union and the Soviet bloc. 
imperial-Roman ambitions, which is well reflected in Pirandello's telling statement: "We need a Caesar for another Virgil to emerge." ${ }^{352}$

The most significant difference between Mussolini's and Hitler's attitude to artistic matters lay, however, not just in taste, but in fundamental contrasts between Nazi and fascist totalitarian ideologies. Nazism did not tolerate any modernist stance owing to Hitler's well-known conservatism, and the dogma of racial motives behind all avant-garde art (a conspiracy against Aryan culture) effectively tied the hands of even those among the Nazis who personally accepted some manifestations of modernism in art. Italian fascism, on the other hand, proudly identified with the achievements of futurism as the much desired affirmation of life and modernisation of the national spirit. The fascists also wished to emphasise the separate cultural identity of their revolution, which drew on hopes and slogans similar to those that lured Russian futurists after the Bolshevik coup. Only a revolutionary society, it was claimed, can accept a revolutionary aesthetic. The paintings and other graphic works by Enrico Prampolini, Fortunato Depero, Ernesto Michahelles (Thayaht), as well as the poetry of Filippo T. Marinetti introduced many people into the world of modern technology, which they viewed as a challenge for 'the new human', or rather for the 'new man' favoured by the fascists - a warrior and conqueror of nature, who was to become the fundament of the future empire, while women were to return to the role of "Vestals, priestesses of the hearth." 353 The cult of the machine, especially of the aeroplane (a key motif of futurist art) ${ }^{354}$, very common among young people and encouraged by the authorities, grew partly out of complexes concerning Italy's backwardness (we the modern fascist state are supporters of modern art), but it also provided a pretext for many iconic types of messages extremely useful from

352 The musical consequences of Italy's imperial ambitions were also commented on in Poland. In April 1936 Muzyka Polska informed of a competition for composers for Italy's new national hymn, "appropriate for the new Italy's imperial power." The jury, we read, included such eminent composers as Mascagni and Casella. Cf.: Anon. "Kronika - Włochy" [Chronicle - Italy], Muzyka Polska No. 4, April 1936, p. 368.

353 More on the cultural-political links between the Futurists and fascism, in: L. B. Mosse, "The Political Culture of Italian Futurism", Journal of Contemporary History, vol. 25, Nos. 2/3 1990, pp. 253-268.

354 In particular, the 1929 manifesto of aero-art (aeropittura), signed by Depero, Prampolini and Marinetti, among others, was an apology of a new perspective in art made possible by the bird's eye view from an aeroplane. The changing perspectives of the flight, claims the manifesto, create a new reality, encouraging the rejection of detail and a new synthesis of perspectives. 
the point of view of education and propaganda ${ }^{355}$. These included the visions of young 'knights of the sky' who formed one body and spirit with their steel steeds, as well as the images of machines as a magnification of human power and ability. The innovative so-called 'graphic syntheses' worked out by futurists (visually similar structures used to represent different but thematically related shapes) made possible multiply enhanced expression reaching directly the subconscious - which fully agreed with the policy of creating a homo novus ${ }^{356}$. For, instance, Prampolini's abstract portrait of Marinetti (1933-34) shows a head in a pilot's helmet, which can also be interpreted as a combat helmet or a swimming cap. The geometric figures in the painting may suggest parts of an aeroplane, while the irregular shapes in the background are like features of a landscape. The young man is represented here as a conqueror of the air and water, but also as a 'bird of prey' that descends on the enemy from above. Another characteristic work, Thayaht's sculpture Dux (highly regarded by Mussolini) is also a male head in a helmet - this time clearly a military one, but stylised in such a way that it combines ancient Roman, medieval and contemporary features. What particularly inspired the Italian Duce's imagination was the Latin inscription. The work's extremely comprehensive message includes, as David Odmond-Smith demonstrates ${ }^{357}$, not only an iconic vision of military leadership, but also a metaphor of the head of state as the nation's brain, the mastermind behind all the aspects of its progress.

Though such artistic representations could hardly fail to attract the attention of Nazi leaders in Germany, their forms remained unacceptable for those leaders. Both Thayaht's Dux and Prampolini's works were presented in the early spring of 1934 at an exhibition of Italian futurism in Berlin, and they did not inspire the German hosts' admiration ${ }^{358}$. Berlin critics admittedly refrained from direct attacks, aware of the importance of the planned alliance with Italy - but the Nazi press did not try to conceal its critical attitude to modernism as such, and in the very same year, at a NSDAP assembly in Nuremberg, Hitler denounced modern art as 'degenerate.' The Italian futurists represented by Prampolini immediately

355 See: Maria Elena Versari, "Futurist Machine Art, Constructivism, and the Modernity of Mechanization," in Futurism and the Technological Imagination, ed. Günter Berghaus (Amsterdam: Rodopi, 2009), p. 150.

356 Cf.: David Osmond-Smith, "Masculine Semiotics: the Music of Goffredo Petrassi and the Figurative Arts in Italy during the 1930s", Twentieth-Century Music, Nos. 1-2, 2012, p. 33.

357 Osmond-Smith, "Masculine Semiotics", p. 33.

358 Osmond-Smith, "Masculine Semiotics", pp. 33-34. 
hastened to back up their German colleagues. If the typically German expressionism - a 'national' artistic movement, one could say - has virtually been crushed, and its main representatives have been forced to emigrate, then what does national socialism intend to base its aesthetic identity on? - asked Prampolini ${ }^{359}$. Also Marinetti noted that the Nazis ignored those contexts of modern art that embodied the spirit of modernised nationalism. He expressed his doubts as to whether the Third Reich's cultural policies allow to classify the Nazi movement as revolutionary ${ }^{360}$. Of the greatest importance, however, were the statements from Mussolini himself, who not only publicly supported futurism as the aesthetic representation of 'revolutionary fascist culture', but also clearly distanced himself from the German Nazis' racist obsessions as applied to all kinds of avant-garde movements. "The Führer is wrong in describing Italian futurism and its Russian followers as Levantine or even non-Aryan," said the Duce in one of the interviews in 1934, emphasising that 'fascist culture' does not know the notion of degenerate art. He also stated that he had never been able to understand how "a man like Hitler" could allow the German authorities to wage war on expressionism, which was, after all, "the most outstanding manifestation of German art in the 20th century." 361 This was a paradox that he found incomprehensible. After all (as explained above), one of the leading musical expressionists and a bold experimenter looking to the future - Arnold Schönberg - considered himself a German nationalist and a modernist at the same time. As late as 1931 he still enthusiastically emphasised the profound, organic links between his music and 'the German soil', as well as German tradition in music ${ }^{362}$.

Italy was, at that time, evidently still independent of Germany, which manifested itself, for example, in ignoring racial theories (with the possible exception of colonial-type racism directed against people of dark carnation).

359 Prampolini maintained extremely lively international contacts. He was active in, among others, Zurich, Prague, Paris, and also stayed in Germany, where he was closely associated with members of the Bauhaus group. While in Paris he made friends with many Polish artists, including Jan Brzękowski.

360 According to Jerzy Waldorff's report of 1939, Marinetti supposed that Hitler's negative reaction to German modernism in the fine arts was motivated by petty personal resentments and the envy of a failed painter turned dictator. Cf.: Jerzy Waldorff, “Totalistyczne impresje” [Totalist Impressions], “Muzyka Polska” No 2, 1939, p. 76.

361 Quoted after: C. Salaris, Artecrazia: l'ávanguardia futurista negli anni del fascismo, (Firenze: La nuova Italia, 1992), p. 190. See. also: Osmond- Smith, "Masculine Semiotics", pp. 35-36.

362 Schönberg, "National Music”, pp. 169-174. 
The Nazis' hostile attitude to expressionism, which outside the Third Reich was viewed as a modernised emanation of the German spirit (while in Germany it was only seen as a subversive, 'decomposing' project of the international Jewry) was for Mussolini a strange internal contradiction. In the same 1934, the first tensions between Italy and Germany with regard to racial policies began to appear. When German researchers announced that people living south of the Alps had more 'Negroid' than Nordic features, the Duce reacted with evident irritation, and speaking to thousands of enthusiastic followers in Bari, he announced proudly:

"Thirty centuries of history let us view some doctrines as plainly pathetic, when they are taught on the other side of the Alps by those whose ancestors were illiterate while Rome had its Caesar, its Virgil and Augustus..."363

These widely commented statements made by Mussolini in 1934, when the Italian fascists' cultural policy was still open, and especially the Duce's ostentatious distancing of himself from Nazi racism - all earned Italy and its leader considerable popularity abroad, especially when the situation of artists in Italy was compared with what was then going on in the Third Reich. And indeed, Italy seems to have been the only dictatorial state in that period in which artistic freedom was not smaller than in democratic countries, while at the same time the artists enjoyed the support of state patronage. Foreign media paid much less attention to the behind-the-scenes rivalry of various coteries supported by prominent fascist officials, and to the universal use of manipulation, such as the staged criticism of 'unrecommended' composers. Nevertheless, it was a fact that Luigi Dallapicolla could write his opera Volo di notte (Night Flight, dedicated to the triumphs of aviation) in the twelve-note technique, while interventions of the censors and bans on performances, as painfully experienced for instance by Gian Francesco Malipiero in the case of his opera La favola del figlio cambiato (1934), concerned not so much the technique as the text ${ }^{364}$. One could say that in strictly musical terms, composers were given free choice, and Mussolini the 'musicista' showed equal respect to the futurist avant-garde trends and to all kinds of 'neo-' styles, viewing all of them as expression of the broadly conceived

363 Quoted after: Institute of Jewish Affairs, Hitler's Ten-Year war on the Jews, Kessinger Publishing, 2007, p. 283.

364 It has been suggested that Goebbels was disgusted with the libretto during the German premiere, and Mussolini shared his objections. Ben Earl claims that the reservations concerned large portions of Act Two, set in a brothel. Cf. Ben Earle, Luigi Dallapicola and Musical Modernism In Fascist Italy, (Cambridge: CUP, 2013), p. 162. 
contemporary national Italian spirit. Festivals of contemporary music were generously subsidised by the state and they presented a wide spectrum of European music, including Bartók, Szymanowski, Hindemith, Berg, and Schönberg, with particular emphasis on the music of Stravinsky, whom Mussolini was widely known to admire. The composer himself (evidently naïve in political matters, though not more than the majority of Europe's public opinion at that time) fully reciprocated this sentiment, calling the Italian dictator "a great man, saviour of Italy and Europe," and enthusiastically commenting on his time spent with the Duce, which he counted among the happiest moments in his life ${ }^{365}$.

A similar though less emotional tone can be found in British press reports from contemporary music festivals held in the early 1930s in Italy. Writing on the World Music Days in Florence in the spring of 1934, Richard Capell noted that while in some countries music is much harmed by the attitudes of politicians and their policies, in Italy it can always count on the authorities' favour, regardless of the nationality, race, religion or political views of its composers ${ }^{366}$. Arnold Cooke, in his review of the same ISCM Festival in "The Chesterian", stressed the encouraging fact that in the times of intensely developing nationalism, a society with such aims and ideas as ISCM is so hospitably hosted by a country to which music owes a great debt, all because of the personal patronage of the Duce ${ }^{367}$. An anonymous correspondent of "The Musical Times" admired the organisation of the Contemporary Music Festival in Florence (1937, personally attended by Stravinsky), and in particular - the ingenious concept of incorporating the works of a great Venetian from the past, Antonio Vivaldi, in the programme, which he described as "a stroke of genius" on the part of the head of the repertoire committee, Alfredo Casella ${ }^{368}$. Previously, in a letter to Mussolini (dated 15th September 1928) summing up the ISCM Festival in Siena, the ISCM president Edward J. Dent expressed his admiration not only for the open, liberal atmosphere in Italy, but also for the Italian national spirit in both its traditional and current version; all, naturally, owing to the wise rule of "your Excellency."369

365 Quoted after: Fiamma Nicolodi, Musica e musicisti nel ventennio fascista, (Fiesole: Discanto Edizioni, 1984), pp. 284-285. See also: Erhardt, Strawiński, 265-267.

366 Richard Capell, “The Florence Festival”, Monthly Musical Record, LXIV, May 1934, p. 83, quoted after: Levi, “The Reception of Italian Music", p. 23.

367 Arnold Cooke, "The International Music Festival in Florence”, The Chesterian MayJune 1934, p. 137, quoted after: Levi, “The Reception of Italian Music”, p. 23.

368 F.B. (anon) "Modern Music at Venice", The Musical Times Vol. 78, No. 1136 (Oct. 1937), p. 914.

369 Quoted after: Fiamma Nicolodi, “Aspetti di politica culturale nel ventennio fascista”, in: Illiano (ed.) Italian Music., p. 108. 
Paeans of praise for fascist Italy as 'the promised land' of contemporary art were then published quite commonly throughout Europe, also in the German press (e.g. in Hans Stuckenschmidt's texts published before 1934, shortly before the ban on his writings). Also in Poland it was stressed that - unlike in Germany the Italian

"[fascist] party behaves more like a wet nurse than a policeman. It organises exhibitions and concerts for artists, attracts crowds to these events, finds buyers for works of art, and where there are no buyers, offers government commissions to artists. And this would be about all... The fascists leave an aesthetic appraisal of artistic trends to the ultimate critic, which is natural selection that comes with time." ${ }^{370}$

It must be stressed, however, that the enthusiasm for the idea of universal modernisation, of changing the image of Italy as one huge museum and kingdom of the opera, as well as longing for Roman greatness and the related imperial ambitions - were not the invention of the fascists. These tendencies had already appeared before the outbreak of World War I and took root in the collective imagination of the generation born in the 1880s. According to Wiarosław Sandelewski, the famous virulent (and rather curious) criticism of Puccini by a leading Italian musicologist, Fausto Torrefranca (1912), resulted from an illaddressed protest against the absolute reign of the opera in Italian music life, while the crucial forms of modern instrumental music once invented in that country (the concerto, sonata, sinfonia) were given up voluntarily to the French and the Germans ${ }^{371}$. In the first decade of the 20th century, possibly in relation to Northern Italy's industrial modernisation, this region saw the rise of the most provocative and 'noisy' of the European avant-gardes, represented by the futurists, whose musical visions only came true in the musique concrète of the late 1940s. Even before the fascist era, in the shadow of the Great War, a wave of patriotic enthusiasm swept through Italy, attracting the memory of the national community toward the Latin version of the Blut und Boden ideology, and therefore looking for the roots of its own 'national revival' in the glorious past, looking back to ancient Rome.

370 Waldorff, “Totalistyczne impresje”, p 76.

371 W. Sandelewski, Puccini, (Kraków: PWM, 1973), pp. 169-170. 


\section{The Musical Apologies of Rome in the Service of Fascist Imperial-Historical Nationalism}

Maurice Halbwachs had already claimed before World War $\mathrm{II}^{372}$ that individual memory is relative and depends on the society which shapes it in accordance with its own current rules. The society makes use of collective memory spanning many generations to build a collective vision of the past that corresponds to current ideological norms. In our specific context, collective memory activated such images of the past that corresponded to the nationalist call for a 'national revival' amid the dramatic struggles and the great apocalypse of the Great War. But collective and national memory works in two directions, both backwards and forwards, as Jan Assmann aptly observed ${ }^{373}$. While reconstructing the past, it also imposes the effects of those reconstructions on the present and the future. In the case of the collective memory of a large community such as an entire nation, such reconstructions are carried out most effectively by the state authorit ies. It was the key mission of fascist dictatorial rule as well as Mussolini's personal obsession to project national memory onto the future and bestow a propagandist direction upon this trend.

As we have mentioned, from the moment of seizing power in Italy, Mussolini consistently promoted the mythic romanit $\dot{a}^{374}$ in all spheres of life, from the omnipresence of Roman motifs in urban iconography and the insignia of state authority, to anniversary ceremonies in honour of eminent Roman artists and politicians, to architecture, urban planning (including the demolition of whole quarters of buildings in order to expose monumental Roman ruins), to theatre, film and music ${ }^{375}$. The artists' response for the call for works on Roman subjects

372 Maurice Halbwachs, Społeczne ramy pamięci [The Social Framework of Memory], transl. M. Król, (Warsaw: PWN, 1969). Engl. edition: On Collective Memory, ed. by and transl. by Lewis A. Coser, (Chicago and London: The University of Chicago Press, 1992).

373 "Kultura pamięci” [The Culture of Memory], in: Pamięćzbiorowa i kultura, Wspótczesna perspektywa niemiecka [Collective Memory and Culture. The Contemporary German Perspective], ed. Magdalena Saryusz-Wolska, (Kraków: Universitas, 2009) p. 73, see also: Jan Assmann, John Caplicka, "Collective Memory and Cultural Identity" New German Critique, No. 65, (Spring - Summer, 1995), pp. 125-133.

374 Cf.: Luca Scuccimarra, "Romanità", in: Dizionario del fascismo, ed. Victoria de Grazia e Sergio Luzzatto, (Torino: Einaudi, 2002-2003), vol. II, pp. 539-541.

375 The relation between changes in Rome's urban space and the organisation of musical life in the city was noticed by the foreign press, as exemplified by a 1937 report in The Musical Times approvingly describing the reconstruction of the Augusteum related to the policy of the romanità ("back to B.C. movement"), and to "the increasing 
was a whole series of operas by composers of various generations and stylistic preferences, including: Mascagni's Nero (1935), Malipiero's Giulio Cesare (19341935) ${ }^{376}$ and Antonio e Cleopatra (1936), Respighi's Lucrezia (1936) and Ennio Porfino's Gli Orazi (1941). However, none of these works had such powerful impact on the Italian audience as two compositions on Roman themes (differing in genre and style) which, paradoxically, were written or conceived still before the fascist era. From the point of view of fascist propaganda, the time of composition was irrelevant. What counted was the composers' fame and, most of all, enormous audience acclaim, which led the fascists to include both in the canon of the officially supported 'state music' - as the most desirable sound image of the romanità. These two were: the now almost forgotten and marginalised Inno a Roma (Hymn to Rome, 1919) by Giacomo Puccini, extremely popular in interwar Italy, and Ottorino Respighi's cycle of spectacular symphonic frescoes known as the Roman Trilogy, inaugurated in 1917 with Fontane di Roma (Fountains of Rome) a 4-movement poem, followed by more musical pictures of the Eternal City: I Pini di Roma (Pines of Rome, 1924) and I Feste di Roma (Roman Festivals, 1929).

Puccini and Respighi were perhaps the two most eminent individuals in Italian music of that period. They differed not only in the generation they represented; Puccini, then at the height of his worldwide fame, whose oeuvre can be described as the 'swan song' of the great 300-year period of the Italian operatic tradition - closed an epoch, while Respighi, of Szymanowski's generation, successfully put into practice the postulates of his contemporaries, 'restoring' to Italian music the once lost realm of instrumental music, taken over for centuries by other European nations. Respighi was considered as the great hope of Italian symphonic music, which was expected to win a permanent place in international concert repertoire alongside German, Russian and French works. Though poles apart in age and style, these two artists were clearly identified as national icons, and stole the hearts of the Italian audience in the interwar period as bards of Rome nonpareil. This was naturally noted by the fascist regime, which appropriated both masterful musical incarnations of the officially promoted romanità to such an extent that they were viewed as 'fascist music' for a long time afterwards,

importance of music in Italian social and political life." Cf. anon., "Musical Notes from Abroad - Italy”, The Musical Times, vol. 78, No. 1128 (February 1937), p. 170.

376 Cf. Allessandro Turba, Il mito di Giulio Cesare e il culto della romanità nel teatro musicale dell'Era Fascista: i casi di Gian Francesco e Riccardo Malipiero, PhD diss., Universita degli studi di Milano 2016. file://C:/Users/Dell/Downloads/phd_unimi_ R10055.pdf. Accessed: 01.12.2018. 
which affected their postwar reception. Sometimes - in blatant defiance of the obvious chronology (the dates of composition of the Hymn to Rome and the first part of the Roman Trilogy) - both composers met with accusations of conformism. However, the international position of Puccini, and soon also of his younger colleague in the early 1920s was so strong and significant that they did not need the support of the regime. It was the regime that needed them, and even more - their music.

\section{1 “Salve Roma divina!": Hymn to Rome by Giacomo Puccini}

We usually associate Puccini's Roman fascinations with the famous Tosca, considered as one of his greatest achievements, an opera written in the late 1890s, in which the Eternal City only served as a colourful historical backdrop for the verist drama of life's brutal rules. It is a different case with Inno a Roma. In April 1918, the Roman authorities addressed the then well-known poet Fausto Salvatori with a request for an occasional ode commemorating the victories of the Italian army during World War $I^{377}$. Puccini was soon commissioned to set this text to music. He completed this commission, albeit without much enthusiasm, as evident from his correspondence. The premiere, planned for 21st April 1919 , the anniversary of the legendary foundation of Rome, was to be particularly solemn and festive $\mathrm{e}^{378}$.

Inno a Roma is a piece in the style of a solemn march, made up of two stanzas separated by a lofty, highly patriotic refrain. The text, inspired by Horace's Carmen saeculare, is in some sections (such as the famous reference to the "testimony of the sun" in the refrain) merely an Italian rendering of the Latin original. Musically speaking, the work is typical of Puccini's style with its truly operatic sense of drama, extreme flexibility in the musical expression of textual meanings, and, naturally, the unrivalled simple and highly original melodies, unique to this composer. Both stanzas pulsate with youthful energy that resembles (both in terms of rhythm and melody) one of Rodolfo's leading motifs from Act One of La bohème, and moves from fanfare-underlined invocations to "divine Rome,"

377 The hymn was also an expression of patriotic pride with the fact of the annexation to the Italian state of all the provinces inhabited by Italians that had previously been under Austrian rule. On the wave of national enthusiasm, World War I was usually considered in Italy - despite tremendous economic costs and human losses - as a completion of the great task of the risorgimento.

378 The premiere was cancelled due to a violent storm, and eventually held on 1st June 1919. 
"our fortress and pride," to the description of armed troops stretching as far as the horizon, armour glittering in the sun and the valiant cries of "Sta la Vittoria!" The solar motif, indispensable in the Latin-culture version of the Blut und Boden ideology, here becomes a metaphorical dominant feature of the text. The sun as a witness to both old and recent history of this land lends its glory to Italy and confirms the global uniqueness of Rome. This message is expressed by the refrain, in which, after the final fanfares, the music subsides to a piano dynamic, the punctuated rhythms give way to a mood of solemn concentration, while the inspired song, oscillating around the fifth degree of the scale and combining the qualities of a hymn with the melodiousness of an operatic aria, addresses the "free and joyous" (libero e giocondo) sun rising above the hills: "tu non vedrai nessuna cosa al mondo maggior di Roma!" This conclusion, which stresses the magnitude and magnificence of Rome, is of utmost importance; nothing in the world can compare to Rome. Whether or not this refers to the Eternal City itself or to the entire empire is left to the audience's interpretation ${ }^{379}$. Musically the piece contains such melodic Italianisms which, as a timeless quintessence of Italianness, were adopted by Benjamin Britten in his Seven Sonnets of Michelangelo. They are melodies dominated by progressions based on the intervals of a third, a fourth and steps of a second. It is highly suggestive and has a very strongly impact on the emotions of the audience - at least in Italy. Toward the end of this hymn, the refrain is repeated with full force, as in the Romantic 'repriseapotheoses', while the emotional impact is reinforced by modulating up a fourth.

The British Puccini scholar Julian Budden argues that ${ }^{380}$ Inno a Roma may have been modelled on two marches, both enjoying huge popularity in their respective countries and belonging to the canon of national cultures: The Strips and Stars Forever by John Philip Sousa (1897), which is the official National March of the United States by an act of the U.S. Congress, and the famous Pomp and Circumstance No. 1 in D Major by Edward Elgar (1901), which from the very start has aroused enthusiasm among a wide British audience. Budden criticises Puccini's march as definitely inferior to both its Anglo-Saxon prototypes in terms of catchy tunes and refrain, which in the Hymn to Rome, he claims, becomes helplessly suspended on the 5 th degree of the scale, negatively affecting the value of beauty in the melody. This opinion, however, may result from the author's rooting in Anglo-Saxon culture and from his incomprehension of

379 The British, who, as we know, created an ever larger empire, equally willingly drew on the solar metaphors, stressing that "the sun never sets" on the British Empire.

380 Julian Budden, Puccini. His Life and Work, (Oxford: OUP, 2005), pp. 417-418. 
Puccini's task - which was to write a hymn rather than a popular instrumental march. Budden also most likely forgot that Puccini had been part of a rather different type of national musical culture, in which the vocal-operatic tradition reached very high standards. It is an interesting coincidence that the refrain "Sole che sorgi libero e giocondo..." begins identically as the old Polish national anthem God, Thou Who Hast Poland ${ }^{381}$, in which the 5th degree is also the central (though perhaps not so strongly prominent) pitch. In both cases the ascent to the 8th degree comes with the semantic conclusion - the words "in front of Thy altars we implore, restore freedom to our fatherland" in God, Thou Who Hast Poland (in other periods - a request to bless the country, depending on the political circumstances). In the Hymn to Rome the melody reaches this this top pitch on "tu non vedrai," and the emphatic repetition of "maggior di Roma!" It is, therefore, a clearly rhetorical device stressing the pride of Rome's greatness, as well as probably an iconic representation of the sun rising to its summit to testify that indeed, there is nothing more splendid and greater than Rome.

Regardless of the opinions of foreign critics and of Puccini himself, the Hymn to Rome (variously scored and arranged) became in the interwar period Italy's unofficial national anthem and an indispensable element of all fascist party ceremonies, which compromised the composition as a 'fascist song' and a musical symbol of Italy in that era ${ }^{382}$. However, Puccini's biographers confirm that he was not interested in politics and rejected the offer of honorary membership of the Fascist Party, but gladly accepted the title of senator of the Italian Kingdom, which he received in recognition of his contributions to national culture. He died several months after this nomination. Shortly before his death, he discussed with Mussolini the project of a national theatre in Viareggio, but there is no evidence

381 This hymn was written in so called "Congress Poland" in connection with the planned coronation of Tsar Alexander I as King of Poland. Its text draws on the English "God save the King" and it originally closed with a solemn invocation of "Lord, please protect our King." Soon, however, as the political situation changed, and the hopes placed in the Russian ruler proved vain, the supplication of the refrain turned from that of loyal subjects into a prayer for national liberation. The music also changed in the 19th century, and took its current form in the 1860s, most likely during the January uprising. Cf. Krzysztof Bilica, “'Boże coś Polskę’ Felińskiego-Kaszewskiego. Inspiracje i echa" [ "God, Thou Who Hast Poland” by Faliński-Kaszewski. Echoes and Inspirations], in: Pieśń polska [The Polish Song - A Reconnaisance], ed. Mieczysław Tomaszewski, (Kraków: Akademia Muzyczna 2002), p. 197.

382 About the significance of Inno a Roma for Italy at that time - and for Rome in particular - we can also read in the Polish musical press, which stressed that the City Council purchased the rights to this work. Cf. "Muzyka Polska" No. 2, 1939, p. 106. 
that such meetings served his own interests, or the promotion of himself and his music.

The death of Italian opera's last great master was a shock to the Italian musical world, but also for the regime, aware of the fact that - with the demise of this world class artist - the long period of Italian hegemony in opera had come to its close, and the void could hardly be filled by any living musical personality. The state funeral celebrated the artist as one who expressed the spirit of the nation, and initiated with great pomp the cult of the dead Maestro. This did not conflict at all with support for modernist trends in music. The regime embraced modernity, but attached great significance to the cultivation of tradition at the same time ${ }^{383}$. On 24th August 1930 at Torre del Lago, a Puccini Festival was ceremoniously inaugurated, and the fascist l'Organizzazione Nazionale Dopolavoro (a leisure-organising body, literally 'after-work') played a prominent role in the organisation of this event, tellingly advertised as "una festa unicamente popolare." All this aimed at both general education of the nation and the nationalist propaganda of Italy's cultural superiority to other nations ${ }^{384}$. Naturally, Puccini's music played a key role in the travelling shows and spectacles held in picturesque historical scenery. But, paradoxically, his 'Paris' opera La bohème proved more to the regime's taste than the 'Roman' Tosca. This may have to do with the prophetic Act Two of the latter opera - possibly the first such artistic vision of the terrifying brutality and omnipotence of the secret political police, which was of key importance to all 20th-century dictators.

Puccini - well-known as a man of the world - does not seem to have yielded to any form of chauvinist exaltation promoted by fascists and appears not to have reciprocated in any way the ostentatious admiration of the regime. In unofficial conversations at international conferences dedicated to the political context of music in that period one can often hear that his untimely death in

383 The whole Italian territory was traversed by travelling theatres, the so-called thespian trucks (carri di tespi), which presented the national operatic legacy to those social groups that had previously had no contact with such elitist art. Fascism was notably pluralist in its attitude to the aesthetics of all artistic discplines. Modern steeland-glass edifices were erected throughout Italy alongside neo-Classicist Roman stylisations. Cf.: Marla Susan Stone, The Patron State: Culture and Politics in Fascist Italy, (Princeton, N.J.: Princeton University Press, 1998), p. 4.

384 Michela Nicolai, Puccini "compositore di stato?" Strumentalizzazione di un personaggio publico durante ilfascismo, a paper delivered at the International Musicological Conference "Music and Propaganda in the Short Twentieth Century", Pistoia (Italy), 18th-20th May 2012. 
1924 'saved' the Maestro (known for his skilful care for his own interests) from a compromising flirtation with Mussolini's regime. Nevertheless, all such claims are just groundless speculations.

\section{2 "Tutto che al mondo è civile, grande, augusto, egli è romano ancora!" Ottorino Respighi's Roman Trilogy and the Nationalist Musical Aesthetics of the Fascist Era}

While the Hymn to Rome was marginal to Puccini's output, Respighi's Roman Trilogy is undoubtedly one of his greatest and most representative achievements, which overshadowed all his other works, including a large number of operas and ballets. Already in the composer's lifetime, the compositions forming the cycle broke all records of popularity, receiving thousands of performances in Italy and abroad, which turned Respighi into a true champion and a leading figure in Italian contemporary music. The popularity of the successive parts to the Trilogy soon translated into material prosperity for the composer, while the universal admiration he received, his masterful orchestrations which earned him a place among Europe's leading orchestral virtuosi, as well as the success with which he applied his skills to promote the artistic vision of the romanità - all brought him the regime's recognition. As Harvey Sachs aptly observes, Respighi was the only representative of his artistic generation who earned the support of the regime without any efforts on his side, and in fact - without need for such support $^{385}$. He was also the only one to fulfil the postulates of his generation effectively enough to win the status of Italy's first great symphonist in a few centuries, whose orchestral skills matched those of the greatest masters of orchestral music - Ravel, Strauss, and Stravinsky.

We should remember that Mussolini provided considerable support for orchestral music ${ }^{386}$. The reason was not only the national ambition to regain an artistic field of expression once lost to the French and the Germans. The orchestra was for Mussolini a metaphor of a perfect society, an expression of collective discipline and of submitting individuals to totalitarian authority - that of the conductor. Though in the opera - the traditionally Italian genre - organisation and discipline are also necessary, the figure of the conductor is definitely

385 Harvey Sachs, Music in Fascist Italy, (London: George Weidenfeld \& Nicolson, 1987), p. 132.

386 This support also manifested itself in the formation of new, permanent symphony orchestras, among others in Florence, Turin and Rome (Radio Orchestra). Cf. Earle, Luigi Dallapiccola, pp. 71-72. 
overshadowed by the great stars of the stage, whose personalities, whims and other eccentricities make the functioning of absolute leadership, so typical of the orchestra, virtually impossible. What was also important for the new fascist-type nationalism was the need to revise historical stereotypes rooted in 19th-century traditions. This is why in 1931 Italian diplomatic posts received a note from Mussolini, which ordered them to actively promote a modern image of Italy, with particular emphasis on fighting the stereotype of an Italian "tenor with a mandolin." 387

It was undoubtedly Respighi who contributed the most to overcoming this stereotype. Each successive work in the cycle proved highly successful, but the culmination of his career came with Pines of Rome, and in particular - the impressive final march, which could be interpreted as a nostalgic memory of Rome's former power and a glorious vision of Italy's contemporary imperial ambitions. The work was received enthusiastically by the Italian public and soon after by concert-goers worldwide. At the same time, as Christoph Flamm points out in his study ${ }^{388}$, the nationalist Italian critics noted with great satisfaction that Italian national symphonic music had made significant progress. In the context of the success of Pines of Rome, Nino Rossi summed up the orchestral achievements of Malipiero, Pizzetti, Alfano and Respighi, which formed a kind of crescendo leading to the Bolognese composer's momentous work ${ }^{389}$. Having traced back this buoyant development, Rossi went into raptures over Respighi's most recent work, describing it as imbued with healthy power, profoundly Italian and Roman, a confirmation of the old truth that "Tutto che al mondo è civile, grande, augusto, egli è romano ancora!" ("All that is civil, great and august in the world is still Roman!" $)^{390}$ Rossi's admiration was echoed by Alberto Gasco,

387 Cf.: Richard Taruskin, “The Dark Side of the Moon”, in: Taruskin, The Danger of Music, p. 208.

388 Christoph Flamm, " $<\mathrm{Tu}$, Ottorino, scandisci il passo delle nostre legioni $>$. Respighis "Romische Trilogie" als musikalisches Symbol des Italienischen Fascismus?" in: Italian Music in the Fascist Period, ed. Roberto Illiano, (Turnhout: Brepols 2004). pp. 348-350.

389 Nino Rossi's appraisal was confirmed in the 1930s by many foreign correspondents. E.g. Nancy Fleetwood stressed the significant increase in the presence of Italian orchestral music and of renowned Italian symphony orchestras in the programmes of German concert halls. Similar conclusions can be drawn from Otto Meissner's reports from Berlin printed in the Polish press. Cf.: Nancy Fleetwood, "Musical Notes from Abroad - Germany,” The Musical Times, Vol. 78, No. 1138, December 1937, p. 1073.

390 Nino Rossi, “'Pini di Roma””, il Resto di Carlino, 5th June 1925, quoted after: C. Flamm, "<Tu, Ottorino>", p. 348. 
a leading ideologist of the national revival among Italian critics, who called the final march of I Pini di via Apia "an orgiastic apotheosis of Rome," and claimed it made the composer worthy of honorary citizenship of the Eternal City. Gasco noted that the recording of a nightingale's song played back from a gramophone record toward the end of the 3rd composition of the cycle was, according to some opinions, too realistic, but this possible flaw was quite forgotten while listening to the final march, with its note "di romanità stupenda." ${ }^{391}$

The opinion of a critic as influential as Gasco, who had already in 1917 hailed the success of Fountains of Rome as a reflection of "our land, race and today's passions" (nostra terra, nostra razza e nostri passioni odierni) reflects very well the nationalistic exaltation that accompanied the reception of the Roman Trilogy. Most significant, however, was the view presented in the official fascist magazine L'Arte fascista four years after the success of Pines of Rome. The author of this extensive review, Nicola Melchiorre, discussed the first two parts of the Trilogy composed at that time, praising Respighi for creating his own individual and national style, and in fact presenting him as a model to imitate:

\footnotetext{
"We can say without exaggeration that Respighi, with his strong personality, is one of the few contemporary artists who, while not losing contact with the cultural achievements of recent European thought, knew how he could employ those achievements to carry out his own personal ideas, which are perfectly in tune with the country's cultural traditions and respond to the needs of our time." ${ }^{392}$
}

Thanks to Respighi's symphonic poems, Melchiorre argued, such values as "beauty and purity of form," clarity of artistic expression, and an attempt to look objectively at the world outside - all attributes of the Italian way of thinking and emotionality - were restored to music. Italians, writes Melchiorre, were never fond of exploring shades of indefinite realities and the irrational depths of human nature. Respighi distances himself from the vagueness of impressionism, though he had learnt much from this trend, as well as from a psychological-subjective type of expressiveness. He rejects all the external, superficial and mechanistic sound experiments, and does not yield to the temptation of a simplistic

391 Alberto Gasco, I Pini di Roma del m.o Respighi, "La tribuna", 16th December 1924, quoted after: Flamm, “<Tu, Ottorino,>”, p. 347.

392 Nicola Melchiorre, "Respighi ed i sui poemi”, Larte fascista, III/10-11, 1928, p. 398: "Senza dubbio il Respighi è una robusta personalità, e uno dei pochissimi maestri moderni che, senza perder d'occhio le conquiste spirituali del pensiero europeo dell'ultimo ventennio, ha saputo sottomettere le conquiste medesime ad un concetto proprio, personale, aderente perfettamente alle tradizioni culturali del proprio paese ed anche ai bisogni del tempo." 
borrowing from the closed chapters of the past, though he does not negate that past - as had sometimes been done by Stravinsky and his followers. Respighi replaced impressionistic vagueness with formal clarity and rationality, as well as distance from tradition - with a modern and creative approach to tradition. In this way, as Melchiorre emphasises, he created an individual style that can at the same time be universally understood, and thus restored to Italian orchestral music the position that it had occupied centuries before, making music reflect present-day life. To sum up, he argues that in his Roman symphonic poems:

"Respighi is a true classic, if by classicism we understand the ability to express one's own ideas while preserving formal clarity, balance and eurhythmic quality. He rejects all that is superficial and redundant, nor does he elevate to the status of art that matter that is still in the process of fermentation." ${ }^{393}$

Melchiorre's only criticism of Respighi's two pieces concerned their imperfect internal unity, which means that organic unity is not distinctly audible on the purely musical level. Still, in the last section of his review, the author doubts the legitimacy of such criticism in the context of Italian national traditions:

"Music indeed is a combination of many parts that make up a composition, whose formal unity is desired because it enhances the music. But we all know that this unity is more apparent (apparente) than real, more intentional than natural, more external than internal..." 394

Melchiorre does not expand on this subject, but from his frequently emphasised references to the uniqueness of "our national way of thinking (nostro pensiero nazionale)" we can glean that he was distrustful - in a typical Italian and Mediterranean fashion - with regard to the speculative, abstract and autonomous aspects of music composition and understanding. This distrust, combined with the dislike of intellectualism openly declared by the fascists and their glorification of action, vitality, the laws of life, becomes clear why such criticism, which would probably be taken much more seriously on the other side of the Alps, melted in the face of the enthusiastic reception of Respighi's music by a wide audience. The neo-impressionist illustrative quality and naturalistic tendencies of that music were greeted as an aesthetically legitimate and desirable attempt at an objective representation of the world. It was assumed that they not only

393 Melchiore, "Respighi”, p. 398: "Insomma il Respighi in questi lavori e un vero classico, se classico vuol dire esprimere le proprie idee con compostezza ed eurytmia di forme ed equilibrio di part, mettendo la banda tutto cio che e vano e superfluo, e non assumere a dignita di arte quello che e ancora materia In fermentazzione."

394 Melchiore, "Respighi”, p. 400. 
exhibited a type of unity, but that this unity would be perceived by every person who at least becomes acquainted with the titles of the successive movements of the two poems, with no need for an analysis of their musical contents. Unity of time, of imagined space (though in Pines of Rome unity of time is dubious) inevitably released a wealth of impressions, memories and emotions related to the city of Rome. In this case, the subject matter itself guarantees unity, more on the level of narration and associations than that of musical form. One can hardly fail to observe that, despite applying the advanced technical tools of the modern symphony orchestra, Respighi's way of integrating his instrumental symphonic cycle is similar to that used previously by Vivaldi, for instance in his famous Le quattro stagioni. For Vivaldi, the unifying factor was the imitazione della natura resulting from the Renaissance and Baroue artistic apology of the laws of nature, manifesting itself in all latitudes ${ }^{395}$. Respighi, in his turn, refers to those attributes of the Roman metropolis that are known both to its inhabitants and to Rome's admirers in the country and worldwide. In this context, the complete agreement between Respighi's cycle and the canons of "national thinking and feeling" (stressed by Melchiorre and variously confirmed by other reviewers) explains why the Roman Trilogy was hailed as a symbol of the recently accomplished national revival.

\subsection{From Rimsky-Korsakov to Giannotto Bastianelli: Transformations in Respighi's Aesthetic Stance on His Way to the "National Revival"}

Let us now trace back the evolution of Respighi's style against the background of the developing identity of the generation referred to in Italian musicology as the generazione dellaottanta. Early in the 20th century, motivated by similar impulses as the eminent representatives of Young Poland with Karłowicz at the head of this movement, Respighi left Italy to learn from the greatest masters of the symphonic tradition at that time. In Poland this trend was described as "snatching the knowledge from the Germans," but Respighi started with St.

395 Notably, it was largely thanks to the musicological preoccupations of composers belonging to Respighi's generation (Casella, Malipiero, and others) that Vivaldi's concertos were restored to musical practice and the wealth of Baroque Italian instrumental music was rediscovered.Cf:. Catherine Paul, "Ezra Pound, Alfredo Casella, and the Fascist Cultural Nationalism of the Vivaldi Revival", Quaderni di Palazzo Serra 15 (2008), pp. 91-112: http://www.lcm.unige.it/ricerca/pub/15/05.pdf, accessed: 16.10. 2017. 
Petersburg, where he took, from what we know, several lessons in orchestration from Rimsky-Korsakov himself. Later he travelled to Berlin to study composition with Max Bruch. Understandably as this decision may be from the Polish perspective, it could also come as a surprise. After all, the young Respighi had his great compatriot Giacomo Puccini much closer at hand. The latter's orchestra though subordinated to the principles of operatic art - sparkled with all colours and its sound was no less magnificent than that of Wagner or Debussy, a far cry from the stereotypical orchestral accompaniments of earlier Italian operas. Possibly the much overworked Maestro had no time for pupils at the height of his fame, but it is equally probable that for Respighi, Puccini's music was aesthetically 'out of the way', as in fact suggested by the opinions of young Italian composers (surprising to the Polish ears), who claimed that music in their own country was in a state of 'crisis', and which was their task to overcome. One reliable exponent of that generation's aesthetic views was Alfredo Casella, who, like the previously quoted Fausto Torrefranca, viewed verismo in opera as 'commercial', not as $\operatorname{art}^{396}$.

In 1910, in obvious imitation of the Russian Five (the Mighty Handful) Respighi, Gian Francesco Malipiero, Ildebrando Pizetti, Renzo Bossi, and Giannotto Bastianelli (a leading modernist critic) formed the Italian Five (Cinque Italiani), whose aims were similar to other earlier national schools, but significantly modernised ${ }^{397}$. Similarly the Young Poland aesthetics saw modernisation as an urgent need, and this view was shared by such different personalities

396 It is highly characteristic of that period that so many outstanding Italian composers of that generation chose to study abroad in Europe's main music centres. Casella studied composition with Gabriel Faure in Paris (his fellow students at Paris Conservatoire included Ravel and Enescu) Malipiero - with Max Bruch in Berlin, and later in Paris, Franco Alfano - with Sitt and Jadassohn in Leipzig.

397 Nevertheless, in 1932 the artistic paths of Respighi and Malipiero diverged. Dailies in Milan, Rome and Turin published a "manifesto of Italian musicians," authored by Alcesto Toni, which defended 19th-century Romantic traditions. This text, also signed by Respighi and Pizzetti, was directed against Casella and Malipiero, though no specific names were mentioned. Characteristically, all the aesthetic options of that time - post-Romantic, neo-Classical and modernist - considered themselves as exponents of the national spirit. More on debates on nationalism in music as far as the Respighi's generation was concerned see in: Thomas S. Vitzhum, Nationalismo e Internazionalismo - Ottorino Respighi, Alfredo Casella und Gian Franco Malipiero und die kultururplitischen Debatted zwischen 1912 und 1938 in Italien, $\mathrm{PhD}$ diss, Regensburg University, 2007, https://epub.uni-regensburg.de/10768/1/Dissertation_ Vitzthum.pdf, accessed 10.12. 2018. 
as Przybyszewski, Karłowicz and Szymanowski, also echoing some statements from members of the Mighty Handful.

The main ideologist and spokesperson for the Cinque Italiani was Bastianelli. His views on Italian opera were not as radical and devastatingly critical as those of Fausto Torrefranca, who - as a Schopenhauer enthusiast - saw instrumental music as a 'pure art', elevating it to nearly religious status as a path to spiritual self-knowledge. Bastianelli entered into a polemic with this view. He believed that a real work of art, as an ideal blend of intuition and expression, can be physically expressed by means of any medium. In his opinion, viewing one artistic genre as 'pure' and another as automatically 'impure' is just a fabricated concept resulting from overestimating the value of intellectual speculations ${ }^{398}$. Bastianelli highly valued the music of Mascagni (at least the latter's Cavalleria rusticana), and dedicated one of his books to this verist composer. However, he did share Torrefranca's view that after 1750, Italian opera had entered a period of decadence. Bastianelli also viewed the majority of early 20th-century European music as overshadowed by decadence, which did not stop him from going into raptures over Scriabin's late sonatas, the music of R. Strauss and Stravinsky ${ }^{399}$. According to Bastianelli, what was needed to overcome decadence was "a new diatonic system," which could serve as an alternative for the "chaotic ocean of post-Wagnerian chromaticisms." A return to the historical roots of Italian music, to Monteverdi and the Baroque masters, was postulated; it is in their music that one could look for creative impulse which, properly modernised, would further the 'national revival' in $\operatorname{art}^{400}$.

Respighi's stylistic transformation from darkly expressive, still very 'decadent' and bombastic (in the Northern fashion) post-Wagnerian textures and the rich chromaticisms of Sinfonia drammatica (1914) to the bright and transparent 'new modality' of Concerto gregoriano (1921) show that his aesthetic progress largely agreed with Bastianelli's postulates. Still, it was not the Concerto gregoriano but

398 More on Bastianelli's aesthetic views in: Miriam Donadoni Omodeo, Giannotto Bastianelli, Lettere e documenti editi e inedtii, (1883-1915), 2 vols., (Florence: Leo S. Olschki, 1989-1992).

399 Gianotto Bastianelli, La crisi musicale europea, (Pistoia: Pagnini, 1912). Bastianelli was notably also a composer. His late works, such as Natura morta, 1915 (dedicated to the memory of Scriabin) demonstrate evident influences of the Russian messianist and modernist. Cf. C.G.Waterhouse, "Bastianelli Gianotto", The New Grove's Dictionary of Music and Musicians, Vol. 2, 1980, pp. 280-281.

400 Quoted after: Ben Earle, Luigi Dallapicola and Musical Modernism In Fascist Italy (Cambridge: CUP, 2013) p. 44. 
the much earlier Fountains of Rome that were unanimously hailed by critics and the public as a symbol of the Italian national revival in music.

Christoph Flamm, a German scholar previously quoted as an expert on the music of Respighi, made interesting observations concerning the diametric difference of opinions in the Italian press between Sinfonia drammatica and (just two years later) the first part of the Roman Trilogy ${ }^{401}$. The significant rise in nationalistic sentiments during World War I had led critics to trace and condemn all distinct stylistic influences and borrowings from musical cultures north of the Alps, and German influences were criticised much more severely than French or Slavic ones. This may have had to do with Italy joining the Entente in 1915 , but also with traditional sympathies and antipathies rooted in Italian mentality. Be it as it may, Respighi's Sinfonia drammatica - which Flamm describes as a mature work demonstrating a high level of mastery and technique - proved a failure. Critics did not like its overly intellectual aura, its subjectivism and sombre moods, which seemed at odds with Italy's national traditions. Most of all, however, writers criticised the evident influences of Wagner, Strauss and Mahler. Actually, as Flamm observes, Fountains of Rome were not free of these influences, either. Still they were hailed as typically Italian. Flamm explains this inconsistence with heightened chauvinism, which clearly stopped Italian critics from 'hearing the music clearly'. In the above quoted excerpts from Melchiorre's review, however, we can find a clear distinction depending on the degree to which foreign influences are reworked by Italian composers. Assimilation itself is commendable, as long as the achievements of other cultures are properly assimilated and adapted to suit the national tradition. The musical world of Fountains of Rome, complemented (as in Vivaldi's case) by the composer's programme notes and constituting - according to Respighi himself - the artistic result of his own impressions and views of the Eternal City - is closer to the Mediterranean tradition than the world of Sinfonia drammatica. ${ }^{402}$. It was probably this turn toward illustrative, impressive orchestral music that employed all the musical and extra-musical sources in the service of the two key nationalistic categories of that time - those of italianita and romanità - that influenced the success of the Fountains. The later Concerto gregoriano, though maintained in bright 'Latin'

401 Flamm, “<Tu, Ottorino>" p. 340.

402 Flamm fails to notice to what extent some of Respighi's Wagner and Mahler inspirations are distinctly filtered through the tradition of French impressionism, much closer to the Italian tastes of that time. 
colours and quite devoid of the 'decadent' qualities pointed out by Bastianelli did not win such applause.

Though the superlatives with which a fascist journal greeted Respighi's work significantly contributed to this composer later being associated in the public view with the regime of Mussolini, which cast a shadow on the postwar reception of his music, Melchiorre's emphasis on the prominently national qualities of the first two parts of the Roman trilogy still deserves our attention, especially in the context of the suggestion of some supra-historical 'Italian-ness' or 'Romanity' supposedly essentially contained in the Trilogy, and the interpenetration of these two concepts. Paraphrasing Szymanowski's famous statements, one could claim that Respighi tapped into the 'racial' sources of the Italian (or, more broadly, Latin-cultural) soul. There may be some truth in this conclusion, especially in the categories of the cultural continuity of Rome as the Eternal City.

\subsection{Prophetic Aspects: The Roman Trilogy in the National and International Context}

If we now travel in time from the interwar period not to ancient Rome, but to the second half of the 20th century, to one of Federico Fellini's greatest films, the world famous blockbuster Roma of 1972, widely distributed and watched by cinema-goers (also in communist Poland) - we may recall the final scene, in which a group of bikers ride in the night along Rome's ring road toward the brightly lit ruins of the Colosseum. They bring a youthful dynamic into the revered ancient scenery, and the roar of engines symbolises modern technology. They pass the picturesque ruins and melt into the darkness of the Eternal City, which lies asleep. The opening scene of the same film, a model lesson of 'crossing the Rubicon', shows Rome at dawn, probably some time in the late 1930s. In this film there are many oneiric wanderings through the dark corners of Rome, many evenings, nights and daybreaks, but this main direction from dawn to dusk does find its clear parallel in Respighi's earlier Fountains of Rome. The same is true about the sharp and garish clashes of modernity and tradition, loftiness and triviality, and especially the trips in time represented in the other two parts of the Roman Trilogy. In the film, these are limited to periods preserved in Fellini's own personal memories of his first visits to Rome in the 1930s, while the ancient past is revived in each case 'through the agency' of modern times - of the director's youth and mature years. Thus, the scene of Julius Caesar's assassination later turns out to belong to a theatrical spectacle. We also have a symbolic scene of vanishing Roman frescoes discovered during the construction of Rome's 
underground railway, as well as references to Rome as a centuries-old centre of Catholicism, for instance in the surrealistic-grotesque scene of a 'church fashion show' taking place seemingly outside the temporal framework, at the house of a Roman aristocrat who had not left her house for years and had lost contact with external reality.

Numerous parallels inevitably lead to the (unanswerable) question concerning the extent to which Fellini drew on Respighi's concept of travels in time and the other elements of the latter composer's scenario for the Roman Trilogy. Respighi's symphonic poems clearly anticipate many of the Hollywood soundtracks of super-productions set in ancient Rome as well. His music has a film-like quality in its modern panoramas - one could say that Respighi sensed this quality still in the era of silent movies. Did the cityscape of Rome really influence the composer's creative imagination as strongly as it did many years later with Fellini? The question seems relevant in that the anticipation of filmtype thinking can be found in Rome-inspired stage and musical works already in an earlier period, for instance in the great final scene of Act One of Puccini's Tosca, which opens with Scarpia's ominous order of "Tre sbirri - una carozza," and ends with a powerful Te Deum sung at Rome's Church of St Andrew - one of the earliest operatic prefigurations of collective film scenes. Only a camera, as we know, can bring out the full significance of the sharp contrast between collective a thanksgiving ritual and the police chief's sordid schemes motivated by a fatal passion; only a film close-up zooming in on the face can reveal the full force of this figure's acting.

On the other hand, musical fascinations with great metropolises have their international context. They appeared in the 20th century, first in a cosmopolitan sphere, at a time when turn-of-the-century nationalisms still produced post-Romantic paeans dedicated to natural landscapes while big cities were usually perceived as a source of evil and the loss of national spirit. One of the first portraits of the world's great cities in music is the symphonic poem Paris: A Song of a Great City (1898) by Frederick Delius, a Briton of Dutch-German descent residing in France. The composition, as we read in the composer's own enthusiastic motto attached to the score, extols the French metropolis as a symbol of the powerful laws of life. Delius's stance is similar to those of Feruccio Busoni, known for his anti-nationalistic views, for whom great cities (Berlin in particular) offered a fascinating example of how humans can tame nature. Busoni's urban fascinations are not reflected in his music, but Ralph Vaughan Williams expressed such sentiments (in his case - with a nationalist colouring) before World War I in his monumental London Symphony, which inaugurated the trend of representing metropolitan cities in music not just as unique phenomena of 
civilisation, but as symbols of the nation's achievements and an expression of the sense of a national community's love for their capital.

Musically speaking, Respighi's music is very different from that of Vaughan Williams, but the Italian artist clearly shared his English colleague's national motivation. The whole of the Roman Trilogy exploits those historical attributes of Rome that no other great European capital could boast - manifest references to the power of the Roman Empire and the previously mentioned 'trips in time'. As compared to the two other parts of the Trilogy, Fountains of Rome does not contain flashbacks to the Antiquity, and the journey in time (as in A London Symphony) takes place between dawn (when the city wakes up to life) and dusk. Vaughan Williams did not include such detailed topographic notes as Respighi, but he gave indirect clues in the music itself, for instance by quoting the tune of Big Ben as well as then well-known songs that represented urban folklore or - in present-day terms - the audiosphere of London at that time ${ }^{403}$. Nor did Vaughan Williams fail to represent the famous early morning mist over the Thames or the modern industrial face of the city, present in the piercing roar with which the first movement properly begins, thus illustrating the awakening of the industrial giant.

Rome did not have such well-developed industry at that time, but it had its own unique aura, mythology and history. As we know, Respighi added titles and detailed literary references which leave us in no doubt as to the location of each Roman fountain. He also drew on myths and legends related to the places he portrayed. The melancholy-pastoral intro of the first movement (Andante mosso) depicts the Villa Giulia fountain at daybreak, while the spectacular and lively second movement (Vivo), abounding in post-impressionistic effects and also containing powerful post-Wagnerian culminations, is a morning vision of the Fontana del Tritone. The composer plays with the audience's imagination here, bringing the mythological Naiads and Tritons and for the first time in this piece, attracting the listeners' attention to the city's ancient past. The solemn and dignified third movement (Allegro moderato) depicts the Trevi Fountain around noon, exploiting at the same time the theme of Neptune's pageant moving along the sunlit surface of the water. The nostalgic fourth movement (Andante) brings typical Respighi-esque 'percussive-metal-bar' pentatonic ostinato progressions, his

403 More on the concept of 'audiosphere' in: Maksymilian Kapelański, Wspomnienia dźwiękowe z mojego dzieciństwa we Wrocławiu i w Toronto [Acoustic Memories of My Childhood in Wrocław and Toronto], in: Audiosfera Wrocławia [Wrocław's Audiosphere], (Wrocław: Wydawnictwo Uniwersytetu Wrocławskiego, 2014), pp. 338-345. 
highly characteristic type of melody, as well as impressionist effects: evocations of evening bells, bird songs and the whisper of nature falling asleep in the big city. Respighi probably did not know A London Symphony, so the similarities are most likely a reflection of the 'spirit of the age', the inclusion of post-impressionist cityscape fascinations in a modernised version of musical nationalism in the 1910s. What underlies the successive symphonic frescoes dedicated to the great cities and constitutes its ideological-emotional undercurrent is a wide range of patriotic sentiments, from simple nostalgia in Gershwin's An American in Paris to the titanic struggle with the enemy in Shostakovich's Symphony No. 7 'Leningrad', to the heroic and tragic tones of Bolesław Woytowicz's Warsaw Symphony, to the patriotic aura of Richard Addinsell's famous Warsaw Concerto (written for the purpose of a feature film based on wartime events). It is interesting that the finale of Pines of Rome and the 1st movement of the Leningrad Symphony contain the most effective and best known examples of a march-based crescendo in 20th-century symphonic music. Written in two totalitarian states, both compositions were eagerly employed by the propaganda machines of their respective countries. As we know, this association did not harm the reputation of Shostakovich, who represented the victorious coalition. Things were different with the Roman Trilogy. After 1945, Respighi was accused of conformism, of promoting 'false Romanity', and collaboration with the regime, of which he was admittedly a favourite. This criticism was refuted by Respighi's widow Elsa, who reminded readers (in a letter published in 1945 in "Il mondo musicale") ${ }^{404}$ that Fountains of Rome had been written in 1916, while the finale of Pines of Rome (so frequently associated with a fascist apotheosis of power) was sketched in the early $1920 \mathrm{~s}^{405}$. Until his death, Respighi refused membership of the Fascist Party. Elsa Respighi rejected claims of the composer's debolezza morale (moral weakness) and suggested that his worldview evolved toward some form of tacit opposition, proof of which was supposedly to be found in the final verses of Lucretia that he still managed personally to set in music, and which condemned tyranny. It cannot be ruled out that Respighi (who died of heart attack in 1936) may have felt disappointed and worried in the last years of his life by the growing aggressiveness of fascism in the international scene. He may also have heard of the atrocities and crimes committed by legionaries of the 'New Rome' in Abyssinia. It also seems natural that in the conditions of a totalitarian state, only his closest

404 Quoted after: Flamm, “<Tu, Ottorino>”, p. 334.

405 Elsa Respighi, Ottorino Respighi: His Life Story, trans. Gwyn Morris (London: G. Ricordi, 1962), pp. 89-90. 
family could know of the composer's anxieties and doubts. His personal discomfort suggested by the author of the letter may also have resulted from the realisation of the degree to which the Roman Trilogy had been appropriated by fascist propaganda - and the consequences of that fact, as well as the ominously prophetic nature of the final march from Pines of Rome in the context of the events of 1935, which must have appeared to the composer as the irony of fate ${ }^{406}$. On the other hand, we know very well that not being a party member in a totalitarian state does not automatically entail refusal of acceptance for the system, and one must maintain some degree of distance to the memories of widows to prominent cultural figures. Research conducted by Fiamma Nicolodi does confirm that Respighi was apolitical ${ }^{407}$. Little is known of his views since he did not write any reviews or feuilletons, disliked public speeches, and was reluctant to give interviews. The surviving documents from Mussolini's office show that he strove to maintain distance to political authorities. On the other hand, though, he held so many prominent posts in numerous cultural committees, corporations, etc., absurdly inflated by fascist bureaucracy, that his identification with the fascist state's official musical life comes to us as no surprise. One can hardly escape the question of why he accepted all these posts, despite worldwide fame and material prosperity if he really did not quite accept the official ideology. He had no need to promote himself and his oeuvre. Leaving aside the fact that composers were frequently associated with official artistic life and the governing elites of totalitarian states, despite not being party members and remaining apolitical in their own view - there is also the question of the convergence between some aspects of their aesthetics and official demands. The compositional process of the Roman Trilogy undoubtedly started before the fascist dictatorship, as an expression of the composer's own authentic fascinations with the Eternal City. The cycle is his individual artistic vision and impression of the metropolis, whose landscape was, as he would say, dominated by fountains and pines. On the other hand, the illustrative quality in his music comes at times dangerously close

406 On 3rd October 1935 Italian armed forces invaded Abyssinia thus starting a war which was then seen by fascist propaganda as the first step into putting Roman-imperial dreams into action.

407 Fiamma Nicolodi, Musica e musicisti nel ventennio fascista, Fiesole 1984, p. 151. These conclusions are corroborated by Alessia Angela E. Macaluso, Fascist Disenchantment and the Music of Goffredo Petrassi, PhD diss., (Toronto, Ontario: York University,2017), pp. 58-60, (https://yorkspace.library.yorku.ca, accessed: 10.12.2018) and by Jadwiga Marczyńska-Negri: “Respighi, Ottorino”, Encyklopedia Muzyczna Kraków: PWM, vol 7, 2004, p. 368. 
to the garish demonstrativeness of the 'iconic' type of message as promoted by fascist propaganda $\mathrm{a}^{408}$, devoid of intellectual content but ensuring a direct impact on a very wide scale. The above-mentioned 'trips in time' in the 2 nd and $3 \mathrm{rd}$ parts of the trilogy bring in strong expressive contrasts and a 'Roman' realisation of the principle of 'unity in diversity', anticipating, as suggested above, the later film techniques. On the other hand, they also constitute a kind of parallel to how fascist propaganda handled the mythology of Rome, disregarding such 'issues of secondary importance' as historical truth, but drawing arbitrarily on the Empire's and the city's history, as well as the entire Roman culture, in ways which were politically convenient at that time.

Naturally, this similarity cannot be used as a charge against Respighi the composer, who had the right to feel and interpret Rome as his artistic conscience suggested to him. One can also hardly blame the author of the Roman Trilogy and other Italian composers of his generation for the lack of open opposition to fascism. Like the majority of the Italian society, those composers greeted the regime's modernising efforts with approval. The myth of romanita proved to be an ingenious and highly effective tool in the hands of propagandists. Not only did it work on the mass imagination, but it authentically integrated the whole society. The situation only started to change after 1935, which gradually led to a collapse of the Roman myth and - as a result of wartime events - expose the theatrical, superficial character of the ostensibly reborn 'empire'. The key turning point in politics and ideology, which was also the first step on the downward path that led fascist Italy to a catastrophe, was the subordination of that country to the aggressive policies of the Third Reich, and especially passing the racial acts, which stood in contradiction to the ideological foundations of Italian fascism and to that interpretation of the mythic romanità which Mussolini intensively promoted among his compatriots back in 1934. But this was a change that Respighi - perhaps luckily for him - did not live long enough to see.

408 According to Janet and John C.G. Waterhouse: "Parts of Pini di Roma (...) evoke something of atavistic pageantry that became associated with fascist propaganda", see: "Respighi, Ottorino", The New Grove's Dictionary of Music and Musicians, vol. 21, p. 215. Polish authors, on the other hand, tend to associate the characteristic garishness of Respighi's music with Italian national qualities rather than with politics, see: Bogusław Schaffer, “Ottorino Respighi”, in: Schaffer, Muzyka XX wieku [Music in 21th Century], (Warszawa: Wydawnictwo Literackie, 1975), pp. 69-71. 



\section{From the Myth of Romanità to Fascist Racism: Italian Musical Thought in the Face of Political-Ideological Changes in the late 1930s}

While the traditional nationalist category of Italian-ness (italianita) drew on the community of language, culture, religion and historical traditions developed in the last few centuries, and on the Italian Peninsula's natural and climatic conditions, the notion of 'Romanity' (romanità) provoked much wider associations. Apart from internal Italian context, Romanity opened up broader international perspectives which allowed Italians to look down on other countries with a sense of cultural and historical superiority. The broadest, pan-European perspective referred to ancient Rome's civilising missions and its effects, beneficial for the entire continent (laying the foundations for many aspects of contemporary Western civilisation, a commonly known fact which fascist propaganda then emphasised). In his speeches, Mussolini never failed to remind his audience about the origins of the triumphal arches scattered across Europe, of the aqueducts found throughout the ancient Empire's territories, Roman law, and cities founded by the Romans such as London or Cologne.

The second, much narrower perspective, derived from the community of Romance countries, the peoples that emerged from under the direct influence of Greco-Roman culture and spoke languages that were descendants of the complex known as lingua Romana. These peoples lived in the sunlit Mediterranean Basin and were referred to in the interwar period as the Mediterranean or Latin race (razza latina). Characteristic examples of apologies for this race can be found even in the writings of such (then) world famous artists as the composer and futurist painter Luigi Russolo. This is how he described (in 1933) the expressive qualities of Sardana catalana, the Catalan national dance:

"The gravity and dignity of gestures, the lightness and agility of movement, the solemnity of the ritual. The serenity of youth, joy of life, nobility of gesture. The noble and eternal youth of the race, the Latin race, which discovers so much beauty, cheerfulness, youthful spirit in itself, so many fresh modes of development. And despite all this, this 
race has been submitted to an invasion of American dances that can be described as an epileptic gift (regalo epilettico), such as the foxtrot, the Charleston, and the Black Bottom." 409

Later, in the same text, the author opposed the socially integrating model to some sinister 'anti-model', alluding to the "barbarian invasions" of Rome, and the later, equally barbarous treatment of ancient remains, which leads him to a rhetorical question: What is the fate that a race, submitted to constant invasions of the barbarians, must suffer ${ }^{410}$ ? Some talk of decadence, says Russolo, but what does this decadence really affect? Possibly the political institutions, but definitely not the physiological strength of the race itself. Human races, like every organism, seem to need sleep and rest. What comes after that sleep is an awakening. It may possibly be taking place right now, claims Russolo, and will let the race shake off all the "barbaric, parasitic growths," because - he concludes - "though the names of the barbarians change, as do the continents and methods of invasion, they always remain one and the same thing - common barbarians."

This way of thinking, very widespread in the 1930s, became a foundation that defined the inherently 'Latin' form of racism partially based on the works of Italian anthropologist Giuseppe Sergi and his concept of the Mediterranean race ${ }^{411}$. One cannot fail to notice, however, that the arguments quoted by Russolo have a very

409 “Serietá dei volti compostezza leggerezza agilitá dei movimento. Serieta di rito. Serenitá di giovinezza - gioia di vivere nobilta dei tipi e dei gesti dei movimenti. Nobilta eternamente giovane della razza. Eternita della razza latina. Questa razza che ritrova in se stessa tanta bella serenita di gioia, tanta giovenile e fresco maniera di espanderla, si è lasciata invadere tuttavia dalle danze - regalo epilettico d'America Foxtrot, Charleston, Black-Botton". Luigi Russolo, La sardana catalana - a paper in manuscript, prepared for publication in "Dinamo Futurista"; the original spelling and punctuation have been preserved. Quoted after Gianfranco Maffina, Luigi Russolo e l'arte dei rumori, (Torino: Martano, 1978), pp. 295-296. See also: Carlo Piccardi, "La parabola di Renzo Massarani, compositore ebreo nell'ombra del facismo", in: Music and Dictatorship In Europe and Latin America, ed. Roberto Illiano, (Turnhout: Brepols, 2009), p. 316.

410 Interestingly, a similar opinion was also expressed in 1926 by Mascagni, who wrote from a radically different aesthetic standpoint. He claimed that jazz was a "convulsiveasthmatic" product of "barbarism" similar to opium and cocaine. Cf. Vincenzo Alaimo, "La razza in musica nel ventennio fascista", in: Illiano (ed.), Italian Music, p. 238.

411 Cf. Giuseppe Sergi, The Mediterranean Race: A Study of the Origins of European Peoples. (London: Walter Scott, 1901). According to Sergi's theory, which opposed the theory of 'Nordic race' supremacy, the Mediterranean race was an autonomous one and not derived from the peoples of the North. It is to the Mediterranean race, he argued, that we owe the flourishing of the ancient world's greatest cultures: Egypt, Greece, and Rome. It was also from that race, Sergi believed, that the peoples of lighter 
long history and look back to the beginnings of the conflict between Rome's sophisticated culture and the 'barbaric Germanic tribes' as well as other invaders from the North. Notably a similar historiosophic model underlies the thesis promoted by Vincenzo Galilei and other prominent intellectuals of the Italian Renaissance that the light of all the arts and sciences had only been restored by the Renaissance after Europe had been plunged into the ignorance of the Middle Ages and that the Renaissance awoke culture from the lethargy into which it had been pushed by the barbarian invasions of Rome ${ }^{412}$. We know that the North did not remain silent in this controversy. Already Martin Luther voiced his deep-rooted distrust of the Roman Catholic Church as an institution that was a transformed and disguised form of old Roman imperialism. However, the major offensive of the 'Germanic North' only took place three centuries later.

Aaron Gillette observes ${ }^{413}$ that it was early German Romanticism that rejected the claim of the fundamental significance of the Roman heritage for European culture. Herder promoted the thesis that nations had their collective psyches, which turned individual cultures into manifestations of the nations' collective spirit (Geist). The myth of the Aryan race, from which the ancient Greeks, Romans and Germanic peoples had supposedly descended, is attributed to K.W.F. Schlegel. Since Germans dominated this field in the 19th century, it comes as no great surprise that in most cases they saw only Germans and possibly also Scandinavian and other Nordic peoples as representatives of the 'true', non-adulterated Aryan race. As Germany was turning into an economic power and the leader of civilizational-technological progress after the country's unification, while at the same time preserving the status of the 'land of philosophers, composers and poets', the view that Germans were closer to ancient Romans than Italians was voiced more and more frequently. The eminent German historian, lawyer and writer Theodor Mommsen openly claimed that the noble and creative Hellenes and Romans had been of the Aryan race, while contemporary Italians are merely their degenerate copy that had lost its original qualities as a result of numerous racial mixes. ${ }^{414}$ Similar views were also expressed by the

skin inhabiting the regions north of the Alps took their origin. As a result of migration and settlement in various parts of Europe, the Mediterranean race began to lose its original physical traits determined by the Mediterranean climate.

412 Vincenzo Galilei, Dialogo della musica antiqua e della moderna, ed. Fabio Fano, (Milano: Manuziano, 1947). Cf. Enrico Fubini, History of Music Aestethics, (London: Palgrave Macmillan 1991).

413 Aaron Gillette, Racial Theories in Fascist Italy, (London: Routledge, 2002), p. 11.

414 Gillette, Racial Theories, p. 12. 
already mentioned 'classics' of racism: Gobineau and Chamberlain. The latter quoted the clear civilizational primacy of the Germanic North over the Romance South as an argument. At the turn of the 19th century, he wrote:

\begin{abstract}
"The less Germanic a given country, the less civilised it is. From London to Rome one travels from mist into full sunshine, but also from sophisticated civilisation and high culture into a half-barbaric reality - dirt, ignorance, lies and poverty. Despite this, Italy has never ceased to be the centre of a highly developed civilisation, if we were to judge only by the convictions, attitudes and poses assumed by its inhabitants." ${ }^{415}$
\end{abstract}

Chamberlain did not agree with the then popular view that these civilizational contrasts were the result of the decadence of the South. On the contrary, he saw Italian reality as a legacy of Roman imperial culture. The problem was, as Wagner's brother-in-law and bard of Germanic nature concludes, that the backward South had stayed in the backwater of the local culture while the world had made significant headway ${ }^{416}$. Undeniably the view of the racial inferiority of Italians to 'pure Aryans' and the Germanic peoples as supposedly the only legitimate heirs of ancient Rome - is in complete defiance of the impressive artistic achievements of the Italian Renaissance and Baroque. Chamberlain attempts to explain these paradoxes with the aprioristic ideological assumption that, as he argues, many of the great Renaissance masters had descended from Germanic families that had settled in Italy.

Chamberlain's theses were developed in 1905 by Ludwig Woltmann, whose work on the Italian Renaissance ${ }^{417}$ also continued to give rise to controversy and debates in the 1930s, dividing historians and theoreticians of racism in Germany and Italy. Naturally, the publications of apologists of Nordic culture as racially the most perfect of all Aryan cultures could hardly meet with a favourable reception

415 “...je weniger germanisch ein Land, um so uncivilisiert ist es. Wer heute von London nach Rom reist, tritt aus Nebel in Sonnenschein, doch zugleich aus raffinierter Civilisation und Hoher Kultur in halbe Barberei - in Schmutz, Ignoranz, Lüge, Armut. Nun hat aber Italien nicht einen einzigen Tag augehört, ein Mittelpunkt, hochentiwickelter Civilisation zu sein; schon die Sicherheit seiner Bewohner in Bezug auf Haltung und Gebärde bezeugt dies...”: H. S. Chamberlain, Die Grundlagen des neunzehnten Jahrhunderds, (München: F. Bruckmann Verlag, 1944), Zweite Haelfte, p. 693.

416 These conclusions can be taken as referring to the entire Mediterranean Basin because, Chamberlain concludes, there is more European-ness to be met in New York than in Athens or Seville.

417 Ludwig Woltmann, Die Germanen und die Renaissance in Italien, (Leipzig: Thüringische Verlagsanstalt, 1905). 
in Italy. Italian nationalists such as Carlo Pisacane and Vinzenzo Gioberti were unshakeable in their view that the Italian nation was an heir to the three most civilised ancient European peoples: Greeks, Etruscans and Romans. It was emphasised that ancient Rome's values and achievements had been saved from oblivion in the Middle Ages by the Catholic Church, which - after the fall of the Empire - became the repository of Roman civilization. Italians also reminded their readers that Europe had plunged into chaos and ignorance as a result of barbarian invasions. Rome had given birth to a great civilisation, while the Huns, Ostrogoths and other barbarians only left ruins and charred remains behind ${ }^{418}$.

We have already explained that until the late 1930s racist doctrines played little role in the public life of fascist Italy, and anti-Semitism was not a social problem in this country. It did not go beyond common European resentments related to economy or religion. As in Poland, the teachings of the Catholic Church seem to have restrained the dissemination of racist doctrines. Also the fascist myth of the romanità did not facilitate the spread of racism, especially in its biological version advertised by the Nazis. In his speech in Forum Romanum delivered on 4th June 1924, Mussolini stressed that the fates of humankind had once been decided in that very place, and that Rome had put its visions into practice combining "power and wisdom." The Empire, invariably tough and ruthless in times of war, once the enemy had recognised its superiority, received its opponents "with open arms," bestowing on them Roman rights and citizenship, sharing the benefits of its civilisation, but also respecting the customs and religion of every people: "There is a place for each God in the Pantheon - including the unknown god..."419

This situation changed diametrically, however, in 1938, when it suddenly turned out that the Romans were racists after all. Strict racial segregation was introduced in all the colonies, separating the indigenous population, while in Italy itself the same kind of laws affected the Jews. In July 1938 the journal "Il Giornale d'Italia" printed an article entitled Fascism and the Problems of Race (Il fascismo e i problemi della razza), later known as 'The Manifesto of Race, which officially announced the new 'findings', supposedly confirmed by contemporary anthropological research. The traditional Mediterranean identity of Italians was replaced by Aryan-ness. The onset of a new type of anti-Semitism was also declared, in which cultural-religious criteria were supplanted by biological ones.

418 Gillette, Racial Theories, p. 15.

419 Quoted after: Andrea Giardina, “The Fascist Myth of Romanity”, Estudos Avancados 22(62) 2008, p. 67. 
The main author of this collective manifesto was Dr Guido Landra - head of the Expert Committee for Racial research, established by Mussolini in 1938. He was a lecturer in anthropology at the University of Rome, well known for maintaining close contacts with the Nazis. The Grand Council of Fascism soon passed the infamous racial laws that largely resembled the Nuremberg Laws. The new law forbid Jews to work in state enterprises, employ more than 100 workers in their own private companies, own more than 50 hectares of arable land, serve in the army, take up studies, and belong to the fascist party. "In defence of race" mixed marriages were also forbidden ${ }^{420}$.

The question is, what were the reasons and impulses for this sudden change? Until recently, most scholars believed that it was caused by German influence in the context of a formal alliance with the Third Reich. The latter alliance was the inevitable consequence of Italy's isolation in the international scene after the invasion of Abyssinia. However, in the latest studies the role of internal factors is also taken into consideration. The first of these was the deteriorating economic situation after 1936, which led to social unrest and protests within the fascist party leadership itself. Mussolini responded with a campaign against the 'bourgeois mentality', embodied by the Jews. The second factor was, according

420 More on the persecutions of Jews in fascist Italy after 1938: M. Sarfatti, The Jews in Mussolini's Italy: From Equality to Persecution, (Madison: University of Wisconsin Press, 2000). Notably, the Polish press of that time commented on the Italian racial laws quite widely, and their assessment depended on the political bias of the given press title. Socialist and liberal journalists presented negative opinions about the new laws, while the extreme nationalist writers more or less openly approved of them. Some of the latter, for instance Karol Zbyszewski, even presented fascist Italy as a model for imitation, and sharply criticised the Polish authorities for the lack of similar restrictions in Polish law. Zbyszewski argued that the racial laws were proof that Italy joined the growing camp of 'common sense' - the group of countries that passed anti-Semitic acts, among which he listed Germany, England, Hungary, Turkey, and others. He writes with regret that "in the Polish state bureaucracy, not a single order or law has been passed against the Jews. Nothing! They can ride on trams, work in PAT (Polish Telegraphic Agency - note by AT), be heads of departments, and they are not obliged to wear the yellow patch. They can obtain subsidies, own all the tenement houses, establish secret unions, buy estates, make business, and represent Poland... anything that comes to their heads. The Sanation [Polish government - translator's note] boasts that it has built the first strong and strict state authority in Poland since [King Stephen] Báthory. Indeed it has, but it is strict only for Poles, not for Jews." Cf. Karol Zbyszewski, "Blok zdrowego sensu" [The Common-Sense Bloc], Prosto z mostu No. 39, 1938, p. 8. 
to Andrea Giardina ${ }^{421}$, the need to prevent Italians from "fraternising" with indigenous populations in the new empire, and the last - the need to transform society into a nation of warriors and conquerors. Giardina's opinion is corroborated by Dante L Germino ${ }^{422}$, who believes that identification with the Aryan 'master race' was to accelerate this process and erase the image of the old Italy from the nation's collective memory. Aaron Gilette ${ }^{423}$ suggests that the imposition of a racial identity on Italians and providing them with an 'anti-model' in the form the Jewish race that was a threat to that identity (represented as a more or less openly acting, internal enemy) was to lead, in Mussolini's intention, to the nation's strong internal integration in the direction of an ideal fascist society grounded in the concept of the new uomo fascista. Mussolini naturally decided about everything, but - as Galeazzo Ciano commented - he was, despite all appearances, a wavering person, acting on impulse and yielding to the pressure of various party factions ${ }^{424}$. In this case, especially significant was the influence of a high official, journalist and publisher, Telesio Interlandi ${ }^{425}$, who was also a fanatical racist. Interlandi believed that the achievements of the German Rassenkunde represent modern scientific thought which the 'backward' Italian academics are unable to catch up with. He postulated a resolute modernisation project also in this area. His time came in the mid-1930s, when the young generation of intellectuals came to the fore. Many of them shared Interlandi's admiration for what was happening in the Third Reich. One of these intellectuals was Giulio Cogni - a composer, music theorist and historian from Tuscany, who was also educated in the fields of philosophy and anthropology. During his studies in Germany, Cogni became acquainted with the racial doctrine and for some time was a pupil of the previously mentioned Hans Günther. Cogni wrote a number of texts on racist subjects, published in Interlandi's magazines ("Quadrivio" and "Il tenere"). In 1936 Interlandi introduced his protégé to Mussolini. Most likely

421 Giardina, The Fascist Myth, p. 68.

422 Dante L. Germino, The Italian Fascist Party in Power: A Study in Totalitarian Rule, University of Minnesota, Minneapolis 1959, pp. 27-28.

423 Gillette, Racial Theories, op.cit.p.4.

424 Cf. Roberto Illiano, Massimalo Sala, "Italian Music and Racial Discourses during the Fascist Period", in: Western Music and Race, ed. J. Brown, Cambridge (UK) 2007, pp. 182-200.

425 Cf. Elizabeth Cassina Wolff, "Biological Racism and Antisemitism as Intellectual Construction in Italian Fascism: The Case of Telesio Interlandi and 'La difesa della razza' ', in: Racial Science In Hitler's Europe 1938-1945, ed. Roy Yeomans, Anton WeissWendt, (Lincoln and London: Univeristy of Nebrasca Press, 2013), pp. 175-199. 
at the Duce's personal suggestion, Cogni soon wrote two books (partly based on his earlier articles): Il razzismo (Racism) and I valori della stirpe italiana (The Values of the Italian Heritage, 1937). The former presented the principles of biological racism in Günther's version and praised fascism for its defence of the Nordic race. In the latter he defended the thesis that the Italian nation was indeed a Nordic one, and strove to demonstrate the common roots of Germans and Italians. Notably, neither of these books contained any anti-Semitic accents, which Nazi critics saw as a major fault. Nor were his books favourably received in Italy itself. Elisabeth Cassina Wolff ${ }^{426}$ argues that many of the fascist activists did not like the overly pro-German attitude of the author and the ideas that he promoted, which were alien to traditional Mediterranean thought. The Italian intelligentsia received his ideas with indifference, but the Catholic Church resolutely condemned both publications as neo-paganism and placed them on the Index Librorum Prohibitorum (Index of Forbidden Books).

Undaunted by Cogni's failure, Interlandi employed several journalists of German origin and with them began an aggressive campaign of promotion for Nazi racist anti-Semitism. He also found himself a new protégé - the aforementioned Guido Landra, whom he introduced to Mussolini late in 1937. The Duce, who made up his mind to side with the Germans, soon ordered to prepare the public opinion for the racial laws. The formerly mentioned Expert Committee, chaired by Landra, began its work at the beginning of 1938, and in August of the same year an Office for Racial Affairs (Ufficio per la Razza) was established at the Ministry of Popular Culture. One of its first decisions was to provide financial support for Interlandi's new fortnightly "La difesa della razza" ("Defence of the Race"), which became the main press platform for racism in fascist Italy. Its wide distribution was taken care of by the Minister of Education, Giuseppe Bottai, who was Interlandi's friend. On the minister's orders, subscription for the new fortnightly became obligatory for all university and school libraries in Italy ${ }^{427}$.

In this way, Landra and Interlandi (for whom racist propaganda also proved a real bargain) became Italy's main promoters of 'Nordic' biological-type racism of German Nazi provenance, opposed to the national-Mediterranean type derived from the myth of the romanità and from Sergi's theories. The latter

426 E. Cassina Wolff, “Biological Racism”. p. 182.

427 This order was issued on 5th August 1938, the time of the publication of the fortnightly's first issue. Cf.: Mostra "La difesa della razza" - ideologia e applicazione delle leggi anti-ebraice all' Universita di Torino, 1938-1943, Archivio Storico Universita degli Studi di Torino, Torino: 2010. www.istoreto.it/didattica/Difesa_della_razza. Accessed: 10.01.2014. 
view, however, based on cultural and not biological criteria, still enjoyed greater popularity in Italy and provoked less opposition in ecclesiastical circles. It soon turned out that, rather than integrating Italian society, the racial laws had the opposite effect. They provoked an internal conflict among the elites of the fascist movement, which divided the adherents of the two racial theories, while racial purges at universities and in state institutions created an unhealthy atmosphere of denunciation and intimidation ${ }^{428}$. Landra proved so zealous in his collaboration with Hitler's machine of racial terror, including with Himmler in person, that it began to worry Mussolini. Eventually Landra was dismissed and replaced by an enthusiastic adherent of the romanità ideology - Sabato Visco.

Despite this apparent triumph of the Mediterranean orientation, the apologists of the Nordic race did not lay down their arms. They took advantage of Mussolini's irresoluteness and his difficulties with reacting to the new political situation. The anti-Semitic laws were not withdrawn, but various loops were found in them which made it possible to evade them. For instance, those who could prove that at least one of their parents was Aryan and declared themselves as Roman Catholic, could avoid repressions in this way.

These 'inconsistences' drew sharp criticism from the followers of Interlandi and Landra, who published their texts in "Difesa della razza". As Italy's main platform for the Rassenkunde, this magazine printed, among others, Giulio Cogni's extensive treatise on the relationship between race and music, largely influenced by Eichenauer's Musik und Rasse (see above), though it represented an attempt at a compromise that could end the centuries-long competition of the Romance South and Germanic North for cultural hegemony in Europe.

The historiosophic model proposed by Cogni is based on the assumption that the key driving force of European music is the dialectic of opposites, represented by the two main centres of music composition on both sides of the Alps - the Latin-Romance and the Germanic genius. Mario Pilatti seems to have been the first composer and scholar who understood the laws of music history in this way, and in doing so he anticipated the later political Rome-Berlin $\mathrm{Axis}^{429}$. He wrote in 1933 that, despite true art's ability to cross the boundaries of time,

428 More about this atmosphere, clearly reflected in the correspondence between the composers, in official documents and ministerial orders, can be read in: Roberto Illiano, Massimiliano Sala, "The Politics of Spectacle: Italian Music and Fascist Propaganda”, Musikologija/Musicology, Belgrade, XIII, 2012, pp. 9-26.

429 more on planned cultural German-Italian Axis in late 1930s and early 1940s - see in: Benjamin G. Martin, The Nazi-Fascist New Order for European Culture, (Cambridge (Mass) London: Harvard University Press, 2016). 
geographic and racial borders, Nordic art can hardly acclimatise itself in the warm Mediterranean, while Mediterranean art is unable to "warm up and light up the cloudy aura of the North." Despite these obvious differences, there are some mutual dependencies between the two regions:

\begin{abstract}
"The history of musical art may be viewed in most general categories as a constant mutual exchange between the Latin and the Germanic genius. Can anyone imagine Bach without earlier Italian vocal polyphony and organ music, without our oratorios, our violin and symphonic music? Or German instrumental music, from which the great symphonists were to emerge, without Italian harpsichordists and 18th- / early 19th-century Italian opera? If it is true that (...) now, also in the field of art, we are reviving the great traditions of our fatherland, which have long been forgotten, neglected or even denied - there is no doubt that we cannot disregard in our project the magnificent experiences resulting from two centuries of German hegemony in the field of pure music (musica pura)." ${ }^{30}$
\end{abstract}

Cogni's concept is similar, but is presented in racial terms. He starts with the conviction - borrowed from his German preceptors - that music, as an art close to "the sources of the laws of life", like no other art reflects the character of a given race. Cogni first looks at Italian music for those qualities that help authenticate his thesis (presented in earlier publications) of the common roots of Germans and Italians. He finds those roots in religious music. The Italian church, he claims, cultivated for many centuries $^{431}$ the high and solemn traditions of

430 "Cè ancora da osservare che, in grandissime linee, la storia dell'arte musicale potrebbe compendiarsi in uno scambio constante e alterno fra il genio latino e quello germanico. Potrebbe forse concepirsi un Bach senza la preesistenza della polifonia vocale e dell'arte organistica italiana, del nostro oratorio e della nostra arte violinistica e sinfonica? E lo strumentalismo tedesco da cui vennero I grandi sinfonisti, senza i nostri clavicembalisti e senza l'opera italiana del '700 s perfino del primo ' 800 ? Se è vero che (...) noi siamo finalmente sul punto di ritrovare anche in arte noi stessi nelle grandi tradizioni della patria - per tanto tempo dimenticate, o neglette, o addirittura negate - è indubbio che nel nostro lavoro di riconstruzione non si potrà prescindere dall'esperioenza grandiose accumulatasi in due secoli che viderono l'egemonia tedesca nel campo di musica pura." The quoted text is an axcerpt from a paper given by Pilati at the conference on the 1st centenary of Johannes Brahms' birth in Palermo (Conferenza tenuta al Circolo della Stampa di Palermo per l'Associazione Fascista Donne Professioniste e Artiste). Quoted after: Marta Poggesi, "Mario Pilati e l'ombra del regime", in: Arte, Musica e Spettacolo. Annali del dipartimento di Storia delle Arti e dello Spettacolo, Firenze, V (2004) pp. 30-31. See also: mariopilati.net/styled-6/ code-19/page28.html, access: 18.10.2018.

431 “[...] si continuo nella Chiesa l'álta e solenne tradizione dell’anima ariana mediterranea, che fonde al senso nordico della vita, la vastita solenne e melancholica, ma in fondo 
Aryan-Mediterranean spirituality, based on the "Nordic sense of life," which combined solemn and melancholy vastness (vastità) with "the brightness and serenity of horizons in the South." Cogni also discovered a Nordic quality in the alleged prevalence of major keys in the Italian North; he claimed that as early as the era of the Ambrosian chant evidence of the use of the Ionian mode was documented.

These and many other arguments, claimed Cogni, testify to the common origins of Germans and Italians, which allows him to reinterpret Nazi historiosophic concepts as presented by Matzke and Eichenauer, transforming them into a 'bipolar' model of racial supremacy in the cultural map of Europe. Analyses of several church chant melodies of Italian origin as compared with J.S. Bach's Fugue in C Sharp Minor from Volume I of Das wohltemperierte Klavier lead him to the conclusion that the 'spatial' quality of this music, resulting, among others, from its solemn character and slow tempi, is eminently favourable to contrapuntal and harmonic progressions, potentially already contained in the chant melodies. These "vast harmonic melodies are the true mothers of counterpoint," ${ }^{32}$ he writes, and characteristically concludes that we should not forget their roots in "such a way of being and living in the world" as is typical of the Nordic spirit. Not all peoples have an equally developed spatial sense and imagination. The Aryans are particularly privileged in this respect, since they are sensitive to the laws of organic growth in nature itself. Nature does not create any life limited to just one dimension (una sola dimensione). Cogni considers the sense of harmony and counterpoint as the musical equivalent of the spatial sense, and he observes that the former is manifested in the music of different European peoples to a different extent. He describes complex polyphony as "the faithful image of a well-constructed organism, organised with the same expertise and sensitivity to the laws of motion that governs complicated engineering systems. Mechanics and counterpoint are two ways of expressing the same spirit." Though talents of this kind are exhibited by all European peoples, Germanic peoples particularly excel in these areas since "the Germanic vision of the world is essentially organic, which means that each thing is viewed in terms of organisation." In the field of music, this is reflected in excellent control over vast complexes of sound. So, for instance, a Greek temple exemplifies the typically Aryan ability to

chiara e serena degli orizzonti del sud." G. Cogni, "Razza e musica" (II), Difesa della razza V/8, 20 February 1942, p. 11.

432 "Sono dunque soltanto le larghe melodie armonioso le verte madri del contrappunto", Cogni, "Razza e musica” (V),.No. 11 (V/11), 1942, p. 18. 
organise three-dimensional space, but it represents a simple type of organisation, based on the domination of a single line. Rome added a new dimension to this kind of spatial organisation, transplanting it also into the sphere of sound. This in turn inspired the medieval imagination of the Germanic peoples, thanks to whom polyphony gradually developed on a vast scale. The heritage of this tradition is present in the great sound complexes of Wagner, Reger and Strauss, to whom massive polyphony is just as natural as bel canto is to Italians.

It is highly characteristic, writes Cogni, that the era of polyphony was the work of the Germanic peoples, and the great symphonic tradition was a fruit of German culture. However, unlike Eichenauer and especially unlike Matzke, Cogni does not perceive this historical process in terms of "victory in the battlefield of spirit." Italians, he claims, contributed to musical culture no less valuable elements which have been adopted worldwide. It was the Latin South, claims the Tuscan author, that invented all forms of monody from church chant to the accompanied vocal dramatic forms to classical homophony in which the melody dominates and determines all dimensions of musical structure. This finds its justification in the spiritual qualities of the race, or rather that branch of the Aryan race that has lived for many millennia in blazing sunshine. According to Cogni, the man of the South always sees music as monody. This type of perception is not limited to music only. In the Southerner's way of viewing the world, a single horizontal line always dominates the whole picture. This line is, however, perceived in an Aryan fashion as a kind of 'flight' above the vast expanses of sound or visual stimuli. This is a quality that Cogni finds in Mediterranean architecture, where single horizontal lines tend to dominate over complexes that only exhibit scarce details but are characterised by classical simplicity and noble monumentalism. Graphic equivalents of homophony can be found in Roman architecture, in Italian Renaissance palaces and in contemporary buildings erected during the fascist era. In all of them, Cogni recognises "a breath of the Aryan spirit," and all derive from the aesthetic model that inspired "great Aryan art" - namely, the Greek temple.

Thus in Cogni's view, the greatest achievements of the European musical tradition are the result of mutual transmission and creative development of artistic values that originated in the Aryan genius of the South and the North. These values have been cultivated by nations on both sides of the Alps, which share common origins, but are very different in their perception of, and reactions to, the world. This interpretation, as I have already suggested, is consistent with Cogni's earlier assumption that the mixing of Northern and Mediterranean Aryans was beneficial to culture. On the other hand, according to Cogni, one can hardly compare the Aryan Italian North with the South, whose inhabitants 
have just as much Aryan as Asiatic and African blood in their veins. This view may not be specially emphasised in Cogni's work, but one can sense that the author, who represented the highly developed region of Tuscany, did not consider his compatriots from the South as his 'racial equals', and therefore also equally creative. Though he did not distinctly refer to Chamberlain's theses, his stand was still not satisfying to the supporters of a nationalistic interpretation of the Mediterranean option, which did not mean to give up their claims. Taking advantage of Mussolini's irresolution, the proponents of Sergi's theory presented a definite and inflexible standpoint. Their leader was now Giacomo Acerbo, an influential party activist. In 1941, taking advantage of the institutional protection of the Consiglio Superiore della demografia e della razza (Supreme Council for Demography and Race), Acerbo and his people attacked the apologists of the cultural supremacy of "Aryans from the North," and questioned the myth of the Aryan race, accusing their opponents of ignoring the findings of archaeology, ethnology, and anthropology. How, they asked, could the less numerous Northern hordes change the racial identity of the inhabitants of ancient Italy? Considering the obvious and overwhelming civilizational superiority of Greece and Rome over primitive Germanic tribes, they argued, the alleged 'cultural debt' of Italy is highly dubious. ${ }^{433}$

It might seem that the two camps of Italian racists focused on mutual conflict and never-ending polemics, and left the Jewish question aside. Cogni only mentioned this topic perfunctorily, echoing the tone of the German publications mentioned above (mainly Eichenauer). Thus Cogni draws a parallel between the "excessive chromatisation" which he sees as an evident symptom of decadence in early 20th-century Western music and a similar phenomenon that signalled the decadence of Greek culture in ancient times. In both cases he attributes these phenomena to the intermixing of races and to the influence of the Orient, from which Jewish culture also derives. He believes that flat melodies devoid of the Aryan tendency toward 'spatiality', which he describes as "cantilena melismatica del nomade," might constitute an authentic and wholesome "call of the blood" in the East, but degenerate when transplanted onto Western soil. It should be remembered, warns Cogni, that the Jews as a race have a morbid predilection to all kinds of mixtures and hybridisation, which makes it doubtful whether they remain an authentic race.

Such conclusions provided 'scientific' arguments for a forcible 'Aryanisation' of Italian musical life that began in 1938. Soon after the racial laws went 
into effect, there began the exodus of composers of Jewish origin. Mario Castelnuovo-Tedesco, who left his native Florence in the autumn of 1939, and (largely thanks to the support of Arturo Toscanini) managed to settle in the United States, where he later notched up successes as a composer of film music. The new legal framework proved less of a shock to his friend Vittorio Rieti, who had already resided in Paris for a long period. Renzo Massarani suffered the greatest internal drama and conflict ${ }^{434}$. This pupil of Respighi and great hope of Italian music in the 1930s was an important figure in the official musical life of the fascist state. He was a veteran of the fascist movement, had taken part in the famous march on Rome, and before that - fought in the Italian army during World War I. He considered himself as a patriot dedicated to the case of the 'national awakening. His major status in the Italian arts is evident in the fact that, as late as 1936, his Danza atletica for orchestra was performed during the Berlin Olympics. He was generally highly regarded by critics, who frequently wrote with approval about the 'national distinctiveness' of his music. As of the autumn of 1938, however, performances of his music in Italy were no longer possible. Marginalised and embittered, he emigrated with his wife and three children to Brazil, where he obtained citizenship in 1945 and stayed there until the end of his life. He broke all ties with his native Italy, withdrew all his works and did not agree to any performances, even after the war. It is a historical paradox that in the last several years Italian musicologists have been at the forefront of rediscovering the musical oeuvre of this composer, officially supported and favouritised until 1938. His personal motivation remains a mystery. It is possible that his embitterment had to do with the standpoint of Italian composers, of whom only Luigi Dallapiccola condemned the racial laws - and he did not do it publicly. Like most of his compatriots, Dallapiccola had previously backed up the fascist 'national awakening', but around this time he began composing his famous Canti di prigionia, usually interpreted as the first significant artistic protest against the racial laws. The composer himself suggested such an interpretation in $1953^{435}$, when he recalled Mussolini's radio speech of 1st September 1938 (informing about the new regulations to be introduced) as a shock that provoked in him a need to protest, and turned into a creative impulse for the first part of the cycle - The Prayer of Mary Stuart (Preghiera di Maria Stuart). By 1941, he had completed the other two parts of his triptych: The Invocation of

434 Cf. C. Piccardi, “La parabola di Renzo Massarani”, pp. 171-330.

435 Luigi Dallapicola, “The Genesis of the Canti di Prigonia and Il Prigioniero; An Autobiographical Fragment”, Musical Quarterly, 39/3, 1953, pp. 355-372. 
Boethius (Invocazione di Boezio) and Girolamo Savonarola's Farewell (Congedo di Girolamo Savonarola). The enormous expressive power of this work, its extremely original contrapuntal combinations of the twelve-tone series with quotations from the medieval sequentia of Dies irae, and the theme of imprisonment (frequent in this composer's output) - all speak in favour of his declaration made in 1953. Nevertheless, in recent publications some scholars have expressed their doubts as to the authenticity of these postwar claims ${ }^{436}$. The composer's presentation of dodecaphony as a symbol of 'opposition' toward the regime is questioned, and critics point out the complete lack of any verbal references that could be interpreted as an expression of solidarity with the persecuted Jews. The composer's personal disinterestedness is also put in doubt. His wife, Jewish by descent, had lost her job at the National Library as a result of the new laws, which must have painfully affected the home budget.

Regardless of some researchers' doubts concerning the actual context of the creation of Canti di prigionia, it must be noted that the introduction of the racial laws did dampen the enthusiasm of many prominent Italian musicians for fascism. One of them was Alfredo Casella, who - like Dallapiccola - had a Jewish wife and so was as personally (though indirectly) affected by the restrictions. It was then, in the late 1930s, that the myth of romanita began to lose its credibility in the eyes of many Italians. Fascist propaganda attempted to 'adjust' it to the new political reality by opposing Italians (as contemporary Romans) to the Jews (as descendants of the Carthaginians) ${ }^{437}$. Romanity was presented as stability, patriotism, a sense of loyalty to and respect for the state, while the 'Carthaginian' Jews were to embody a cosmopolitan stance and stood in opposition to the above values. All the same, every observer of current political events would have had to ask, more and more frequently, how Rome could possibly accept secondary status at the side of a stronger ally. The real downfall of the myth came with the realisation during the war campaigns of the blatant discrepancy between the alleged imperial greatness of the 'New Rome' and its evident weakness resulting in compromising military defeat ${ }^{438}$. It was in that period that Mussolini began to be derisively described as a 'Caesar made of plaster', and modern Italians - as 'stucco Romans'.

436 Cf. Ben Earl, Luigi Dallapiccola, pp. 200-202.

437 Giardina, “The fascist myth", p. 67.

438 Giardina, “The fascist myth", p. 68. 



\section{The "New Rome" Clashes with the "Third Greek Civilisation" - The Decline of the Myth of Romanità}

It was the irony of fate, one could say, that this total fiasco - especially in the eyes of its German ally - was caused by a policy inspired by the myth of modern Italy as a continuation of imperial Rome. Like many other 20th-century dictators, Mussolini seems to have fallen victim to his own propaganda and came to believe the reality of the fascist state's theatrical pretence. History was to repeat itself and - as in the Antiquity - 'New Rome' was to incorporate Greece in 1940. But history played a trick on the Italians, and the Greeks repelled the attack successfully enough for the humiliated Duce to have to fall back on Hitler's support.

Back in the 1930s, Italian-Greek relations had been excellent, and the ruling elites in Athens observed the organisation of the fascist state with evident interest. The then dictator of Greece, Ioannis Metaxas, enthusiastically introduced many institutional solutions based on well-tested Italian models, for instance in the fields of public life organisation, social insurance, education and control over the press ${ }^{439}$. Most important, however, was probably the inspiration that sought for an ideology that could effectively integrate Greek society, and especially its young generation. Thus, partly as a response to the propagandist success of the myth of romanità in Italy, Metaxas promoted the idea of "a Third Greek Civilisation," which was to provide the foundation for a great 'national awakening' by creating a synthesis of the country's greatest ancient and medieval achievements. In the face of the contemporary world's challenges, it was necessary, as he often found out during his meetings with young people ${ }^{440}$, to reject 'alien, destructive and decadent models' and return to the life-giving source of one's own culture, which in the case of Greece, as Metaxas never failed to emphasise, was identical with the true foundation of European culture at large. However, similarly as in the case of Poland's Endecja (National Democrats), the

439 Tadeusz Czekalski, Pogrobowcy Wielkiej Idei. Przemiany społeczne w Grecji w latach 1923-1940 [Epigones of the Great Idea. Social Transformations in Italy, 1923-1940], (Kraków: Towarzystwo Wydawnicze "Historia Iagiellonica" 2007), pp. 33-36.

440 Cf. Kathy Romanou, "Exchanging Rings under Dictatorships", in: Music and Dictatorship in Europe and Latin America, ed. R. Illiano, M. Sala, Turnhout: Brepols, 2009 , p. 31. 
Athenian dictator's nationalism did not shun a critical appraisal of the country's cultural history. Each stage of its development had its strong and weak sides. The ancient "First Greek Civilisation" reigned supreme in art, science and philosophy, providing models commonly accepted in European culture as the most perfect. However, according to Metaxas, that civilisation failed to create a strong religious spirit. Under its Byzantine successors, spiritual life and statehood flourished at the expense of science and art. What contemporary Greece needed to do was draw on the strongest aspects of both these cultures of the past and create a "Third Greek Civilisation," ${ }^{411}$ which would dazzle the world with the greatest achievements of mind, spirit and the heart for the benefit of a new state with totalitarian ambitions.

As we may guess, this political programme earned wide social support, similar to Mussolini's Roman dreams and ambitions. A return to ancient roots, the revival of the spirit of ancient Athens - all this could hardly fail to attract applause. Still, the implementation of these ambitious plans was a thing of the (remote) future. In the late 1930s, many leaders of the Greek 'national revival' clearly believed that the spirit of ancient Athens had indeed been revived, but in the German Third Reich. This is the impression that recurs in reports from Berlin written by the main founder of the Greek National School in music, founder and long-time director of the National Conservatory in Athens, Manolis Kalomiris.

Despite official political sympathies for Italy and Metaxas' private esteem for British achievements, Greek culture and economy in that period remained under strong German influence. Kalomiris himself had completed his comprehensive music studies (composition, music theory and piano) in Vienna and was a great admirer of Wagner, whose concept of music drama he saw as a revival of the spirit of ancient Athens. His stay in Russia and contact with the views and music of the Mighty Handful also had some impact on his personal 'national awakening' ${ }^{442}$. However, his travels in 1930s Europe and observations of Germany's flourishing economy and achievements in the field of mass dissemination of culture led Kalomiris to the conclusion that the Reich was the only place where "matter did not dominate over spirit." Music in Germany gained a nearly religious status and acted as a strongly integrating factor for the national community, overcoming

441 Cf.: Romanou, "Exchanging Rings", p. 32.

442 More on Kalomiris's way to national music, in: Ioannis Tsagkarakis, The Politics of Culture: Historical Moments in Greek Musical Modernism Vol. I, PhD diss, Royal Holloway University of London, 2013, https://pure.royalholloway.ac.uk/portal/files /18019596/2013TsagkarakisIPhD.pdf, accessed: 01.12.2018. 
class barriers. Under the National Socialist government, each citizen had access to the greatest achievements of music. Consequently, only Germany, by combining a cult of art with military power and state-of-the-art technology deserved the name of a contemporary successor of ancient Athenian traditions, which in Greece still waited to be revived ${ }^{443}$. In his feuilletons and public statements, Kalomiris wrote with great approval of Goebbels, whose 'highly enlightened' stance, he claimed, could serve as a model for politicians elsewhere. Naturally, Goebbels accepted the effusive Greek's compliments with satisfaction, and - considering the Greek government's favourable attitudes to the Reich and the openly Germanophile attitudes of a large proportion of the Greek establishment - he spared no effort and no expense to promote German culture in Greece ${ }^{444}$. This promotion was also widely commented on in the Polish press, which wrote approvingly (and with unconcealed envy) that "Germany radiated its culture as far as Greece." 445 The German Kulturpolitik was held up as a model to imitate for the Polish authorities. Part of this promotional campaign was the presentation of Wagner's cycle of The Ring of the Nibelung by Frankfurt-am-Main State Opera in Athens (November 1938). In February 1940, the cultural exchange ironically referred to by Katy Romanou as "the exchange of Rings under dictatorial rule"446 also led to a staging of Kalomiris' The Mother's Ring at Berlin's Volksoper. The composer evidently naively believed that his opera was presented in the German capital for the sake of its inherent artistic value. Such politically motivated gestures, meant to achieve a short-term propagandist effect, indeed succeeded in convincing a large proportion of the Greek cultural environment that a true awakening was taking place in the field of music drama, once so deeply rooted in ancient Greek culture, and that Greek music had successfully joined the mainstream of Western art. This conviction was strengthened by the foundation in 1940 of the Royal Lyric Stage in Athens ${ }^{447}$, whose director - journalist and playwright Costas Bastias, the Greek dictator's right-hand man for culture shared Kalomiris' opinion that Wagner's dramas were superior to Italian opera. Undeniably, opera was also rooted in the ancient Greek dramatic tradition, at

443 Cf.: Romanou, "Exchanging Rings", p. 51.

444 Tsagkarakis, The Politics of Culture, pp. 84-88.

445 Anon. Kronika: "Niemcy - Nowe hasła" [Chronicle - Germany - The New Slogans], Muzyka Polska, No. I, 1936 p. 82.

446 Romanou, "Exchanging Rings", pp. 24-67.

447 About the Greek authorities' decision to establish "a national Greek opera” in the old royal theatre house, the Polish press informed already early in 1939. Cf. anon. "Kronika - Grecja” [Chronicle - Greece], "Muzyka Polska” No. 2, 1939, p. 106. 
least at its initial stage of development. Besides, the audience expected and the political situation demanded a clear tribute to Italy. Thus on 24th October 1940 the Athenian theatre premiered Puccini's Madama Butterfly in the presence of the composer's son Antonio and his wife. The Italian ambassador Emanuele Grazzi, also present at the premiere, noted in his diary that he felt extremely uncomfortable knowing that, while the hospitable Greeks were celebrating the triumphs of Italian opera, Rome was planning the conquest of "that hapless country." 448 . In the evening of 27th October, Grazzi saw the Puccinis off to the railway station, and just several hours later handed to Metaxas, Mussolini's ultimatum. The demands, which questioned Greek's independence, were unthinkable, and there could only be one response. Greece refused, and the two countries were at war.

As it soon turned out, the 'New Rome', fixed on the myth of its imperial greatness, had underestimated the enemy's military power. Metaxas was an experienced military leader and proved a tough opponent. Greek commanders succeeded in luring their aggressors into a trap. Eventually the Italian troops were pushed into Albania, Greece triumphed, and Mussolini, humiliated, had to throw himself at the mercy of his powerful ally, who shortly joined in, attacking Greece and Yugoslavia on 8th April and crashing through the joint defences of both countries. On 27th April 1941 the Nazis were in Athens, which Metaxas (possibly luckily for himself) did not live to see (he had died in January). But the myth of romanità was definitively shattered - and for the wannabe fascist 'Roman Empire', this was the harbinger of an end.

After the war, supporters of the Nazis were called to account for their behaviour. Kalomiris, who had prospered under the German occupation, tried to justify his collaboration with the invaders as defence of "the interests of national Greek music," not failing to mention that others did pretty much the same. Italian composers were in a different situation. Nobody accused them of betraying the national cause, and the charge of 'collaboration' with a regime that grew out of their own culture was of an altogether different import. All the same, Italy paid a heavy price for its absurd involvement in the war, and the regime's crimes (which had grown worse as time progressed), and the gradual suppression of freedom gave rise to many uncomfortable questions which composers of music also had to answer. The most common one was astonishment at why they had continued to support Mussolini with their art for such a long time, and how they could naively believe in his fantasy of 'New Rome. The most convincing answer was given - on behalf of his entire generation - by Luigi Dallapicola, who made an

448 Romanou, “Exchanging Rings”. p. 37. 
honest attempt to come to terms with the past, correctly indicating the psychological and social causes of this mass 'delusion':

All of my generation is to blame and we have no excuse (...) It is commonly known, however, that the first cases of an unknown illness cause general confusion and helplessness. The same happened when humanity was confronted with a new secret weapon (...) more powerful than magnetic mines, or even the atomic bomb. The weapon I have in mind is much more subtle and its workings are not openly visible; it took many years to identify it and to reveal its secrets. Benito Mussolini was the first to use it on such a mass scale in the West. That weapon is propaganda... ${ }^{49}$

One can hardly fail to reflect that the much needed 'ammunition' for this weapon was provided by nationalism, chauvinism and racism. It was these ideologies that provided the propaganda with its destructive force on an unprecedented scale.

449 Luigi Dallapicola, "Prime composizioni corali (1961). Postscriptum, 29th January 1962". Quoted after: M. Sala, Preface, in: Music and Propaganda in the Short Twentieth Century, ed. Massimiliano Sala, (Turnhout:Brepols, 2014), p. IX. 



\section{Postscript: The Decline of Racism and Chauvinism, "Crypto-Nationalism" and the Demythologisation of Nationalist Concepts of Tradition after World War II}

To recall Einstein's metaphor once again, it seems that the apocalypse of World War II and the horrors of the holocaust finally began to cure humanity of its 'childhood diseases', though admittedly not the whole of humankind was cured, and not completely. The change was most evident among the inhabitants of Europe, who were probably the first to draw conclusions from these experiences. The memory of Auschwitz and other extermination camps undoubtedly put an end to aggressive biological racism and contributed to compromising other forms of racial doctrine, such as 'pragmatic' racism of the colonial type, though struggles with the latter continued after 1945, since segregation based on skin colour was practised even in the United States, that mainstay of democracy and freedom. Antisemitism in its various forms did survive the war, but was more frequently toned down and became more cultural-political than racist. It was a paradox of history that in the last years of his life, Stalin also gave ear to the theory of 'a global Jewish conspiracy', as though time had stopped for him in the 1930s. Hannah Arendt ironically commented on this change in the dictator's views, writing of brazen imitation of the most obvious symbol of Nazism worldwide, and referring to Stalin's hunt for the Jews as paying his last compliments to his now dead colleague and rival in the struggle for global domination, with whom, to his great frustration, he had been unable to reach a lasting agreement ${ }^{450}$. There is much truth in this commentary, but also some exaggeration, because Stalin in his paranoid mistrust smelled conspiracies literally in every environment, and does not seem to have planned a 'final solution' of the Nazi type. It is, however, also a paradox that late in his life the "great driver of the train of history" managed to combine such seemingly contradictory ideologies as nationalism and Marxism-Leninism, which is reflected in his famous directive to create a socialist art for the Soviet empire that would be socialist in content and national in form (whatever this was supposed to mean) ${ }^{451}$. Polish composers in the postwar period

450 H. Arendt, The Origins of Totalitarianism, p. 356.

451 Włodzimierz Sokorski in his book Sztuka $w$ walce o socjalizm [Art's Place in the Struggle for Socialism], Warszawa 1950, pp. 47-48) stressed that the "agony of 
also had to cope somehow with this paradox, which led (as researchers have frequently pointed out) to a huge number of folklore stylisations before 1956 and an equally massive rejection of this trend after the political thaw. Another wave of ostentatious manifestations of the national sentiment in Polish music under communism came in 1975, as part of the aesthetic of "New Romanticism". It was sometimes signalled by such titles as Krzysztof Meyer's Polish Symphony and Krzysztof Penderecki's A Polish Requiem. One could say, by analogy to Maciej Gołąb's concept of the fluctuations of modernism, that - at least in postwar Poland - we have had something like "fluctuations of nationalism", whose social-cultural role was similar as under the earlier Partitions of Poland. Just as 19th-century nationalism in both its Romantic and National-Democratic forms was an important integrating factor for the Polish nation divided by the Partitions of the country, so its modernised version also effectively integrated all social classes in the 1980s. In the past, Polish nationalism was a response to the imperialism of states that occupied Polish territories. Later, in communist Poland, it became an efficient ideological weapon against Soviet imperialism, and a confirmation of the thesis presented back in 1912 by Zygmunt Balicki that "nationalism as a national and social trend appears wherever national interests are not (sufficiently) secured by the state..." 452 The pontificate of Pope John Paul II led to an unprecedented revival of Polish religious art and to another paradox resulting from Dmowski's stereotype of "a Pole means a Catholic," which strove to combine nationalism with this (apparently) most universalist Christian confession. The Catholic religion, as before, played a vital role in the preservation of the nation's unity (an important historical precedent), while under communism it became an effective antidote for the 'dialectic materialism' officially preached by the state, but also for the cynical opportunism and moral relativism of the ruling classes.

Generally speaking, however, the Polish nationalism of the 'Solidarity' period (apart from evident historical references to its Romantic counterpart, including the very idea of solidarity as a way of building relations within and outside the country) was much more 'discreet' in its manifestations than in the interwar period. Representatives of Polish culture, such as writers, composers and filmmakers, manifested their Polishness more through (consciously or not) references to selected elements of the national tradition than through open

capitalism" does not mean that nations would melt and disappear. Quite the opposite, it leads to their flourishing in a new, "non-antagonistic" form.

452 Balicki, Nacjonalizm, p. 414. 
ideological declarations. This resulted partly from obvious limitations of censorship, since the only then acceptable way of thinking about Poland's political aspirations was 'the Polish way to socialism'. All the same, an attentive audience capable of reading "between the lines" (which was necessary with reference to all texts published under "real socialism") was aware of the obvious parallels between the manifesto of "New Romanticism" in Stanisław Barańczak's Trusting Distrust $^{453}$ and Maurycy Mochnacki's appeals (from before the November Uprising of 1830-31) that opposed Romantic ethos of struggle to Classicist conformism. These parallels led to comparisons between communist Poland and the old Congress Poland ${ }^{454}$ (under Russian rule, after 1815), while the obvious conclusion was that both these protectorates of the Russian empire proved incapable of satisfying the Polish nation's aspirations for freedom.

This type of 'cryptic nationalism' was not always presented in opposition to the regime. Sometimes it was used as a way of demonstrating the national

453 Stanisław Barańczak, Nieufni i zadufani. Romantyzm i klasycyzm w młodej poezji lat sześćdziesiątych [Trusting Distrust. Romanticism and Classicism in the Young Poetry of the 1960s], (Wrocław: Ossolineum, 1971), cf. also: Paweł Strzelecki, "Nowy romantyzm" w twórczości kompozytorów polskich po roku 1975 [The "New Romanticism" in the Works of Polish Composers after 1975], (Kraków: Musica Iagellonica, 2006), pp. 494-495.

454 The Congress Kingdom of Poland (also known as "Congress Poland") was created at the Vienna Congress in 1815 on the initiative of Russian Emperor Alexander I. This was a semi-autonomous state with its own parliament, government, army, constitution (then one of the most liberal constitutions in the world) and currency, it encompassed the largest portion of the territory of the former Polish-Lituanian Commonwealth. Politically and military it was controlled by Russia by means of personal union and command over the Polish Army by Russian Governor in Warsaw. This agreement worked reasonably well till the rather mysterious death of Alexander I (probably the most liberal and most pro-Polish Russian Tsar in the history). Unfortunately Alexander's successor - Nicolai I - announced that he would not continue the liberal experiments of his predecessor, whereupon a hardline course towards Poland was taken which ultimately led to dramatic November Uprising and open Polish-Russian war (1830-1831).In spite of some initial local military successes the Polish Army was crashed by the overwhelming forces of the Imperial Russian Army which was supported by the second partitioner of Poland - Prussia. As it was widely believed that the Uprising saved France and Belgium from the danger of Russian invasion, the November Uprising enjoyed considerable support and sympathy in both countries. As a result, a large number of Polish soldiers, political activists, scientists and artists emigrated to Paris thus making the French metropolis de facto a Polish "spiritual capitol" for the entire 19th century. 
foundations of the ruling ideology. This was the case with one of most likely the last normative theories of socialist realism in music, formulated as late as 1979 (!) by Walther Siegmund-Schulze ${ }^{455}$. For obvious reasons, the author makes numerous references to the writings of Lenin, Gorky and Sholokhov, but the obvious majority are quotations from Marx, Engels, Eisler and Brecht, while musical examples were selected mostly from the works of the most 'progressive' German masters, including classics of socialist East Germany (such as Hans Eisler's Lenin-Kantate) ${ }^{456}$.

Various concealed nationalist motivations, not always fully realised and not necessarily political or ideological, were also to be found on the other side of the 'iron curtain'. One of these were the distinct repertoire preferences evident in the concert life of different European countries, as well as the tendency found in some musicological publications to select subjects for analyses and form value judgments based on a nationalist bias. This tendency was part of a wider phenomenon of 'cryptic nationalism' in aesthetic views, sometimes referred to as 'national musicology'. This is a phenomenon that I will discuss in some more detail.

\section{1 "Crypto-Nationalism" and "National Musicologies"}

The impact of tradition and nationality on the choice of research subjects in musicology is probably obvious. In the Polish context, this phenomenon has been described by Maria Trochimczyk as 'national musicology'457, but to a lesser or greater extent it may be observable in any culture. Though the international canon of musical masterpieces is researched by enthusiasts and researchers all over the world, we take for granted that the majority of studies dedicated to individual composers are (or should be) taken up in the countries which those artists themselves considered as their proper homelands. The case may be a little

455 Walther Siegmund-Schultze, “Theorie und Methode des sozialistischen Realismus in der Music”, in: Siegfried Bimberg, Handbuch der Musikaesthetik, (Leipzig: Deutscher Verlag für Musik, 1979), pp. 160-183.

456 Manipulated ideological references to authentic or invented national traditions can be found in socialist realist discourse of all the countries of the then Soviet bloc. Cf.: Sławomir Wieczorek, Na froncie muzyki. Socrealistyczny dyskurs o musyce w Polsce w latach 1948-1955 [At the Music Front. Socialist realist Discourse on Music in Poland, 1948-1955], (Wrocław: Wydawnictwo UWr, 2014).

457 Maja Trochimczyk, "W stronę muzykologii narodowej: muzykolodzy wobec muzyki polskiej" [Toward a National Musicology: Musicologists Write about Polish Music], "Muzyka" 47, Nos. 3-4, pp. 129-143. 
more complicated with eminent émigrés, who are claimed as 'theirs' by both their countries of origin and those of their permanent residence ${ }^{458}$. Also in the international research environment, representatives of various national cultures are expected to be especially competent with regard to music and works by a composer in their own respective cultures.

Usually the very choice of subject for analysis is tantamount to a positive assessment of its artistic value. Sometimes, however, the values of a given tradition determine a negative choice, and the scholar takes up the study of such elements of technique and composition which he or she considers as aesthetically inferior. As I have already written elsewhere ${ }^{459}$, this was for instance the case with Carl Dahlhaus's risky 'analytic stunts' aiming to prove his aprioristic thesis that the Andante from Tchaikovsky's Symphony No. 5 is kitschy ${ }^{460}$. This led the researcher to rather comic pedantry (such as looking for 'banality' in the dominant seventh chords containing a suspended fourth that appears in the first four measures) as well as to vague accusations such as that "Tchaikovsky's cantilena smacks of kitsch because it is used for something more than emphasis." The author's conclusion suggests that he dislikes the "theatrical bathos" that attempts "to reach some ideal heights." In is naturally impossible to demonstrate analytically what the purpose and meaning of Tchaikovsky's cantilena might be and how it is related to some "ideal heights." We may only guess that all this reasoning was an attempt at rationalising Dahlhaus's personal negative feelings concerning Tchaikovsky's style, and the analysis was an attempt to demonstrate which categories of the composer's technique translated into the author's negative aesthetic experience. But in another of Dahlhaus's texts we find the suggestion that kitsch essentially concerns the sphere of expression, and not of technique, because "kitsch may be

458 This concerns mainly those émigré composers whose greatest achievements took place before they left their countries of origin. A classic example is the career of Sergey Rachmaninov, who in the interwar period was one of the greatest authorities of music life in the USA, as Artur Rubinstein also confirms. The Soviet Russia of that period banned Rachmaninov's music and person completely from its public space for political reasons, but after World War II this ban was lifted, and henceforth the authority of this last of great virtuoso-composers and conductors constantly grew in his fatherland. Presently many Russian musicians and musicologists are convinced that Rachmaninov's music best embodies "the depths of the Russian soul."

459 Andrzej Tuchowski, "Music Analysis in the Light of National Traditions", in: Analiza dzieła muzycznego [Analysis of the Music Work], ed. Anna Granat-Janki, (Wrocław: Akademia Muzyczna im. K Lipińskiego, 2014), pp. 169-185.

460 Carl Dahlhaus, "Über musikalischen Kitsch", in: Dahlhaus (ed.) Studien zur Trivialmusik im 19. Jahrhundert (Regensurg: Gustav Bosse, 1972), pp. 63-67. 
technically irreproachable." ${ }^{461}$ If this is true, then how can one prove analytically that, apart from the author's subjective feeling, for instance the instrumentation of the main theme of a given movement or the relationship between harmonymelody and articulation-volume can be considered as inferior and classified as kitschy?

As evident from the above example, such argumentation has more to do with music criticism than with analysis. The tone of Dahlhaus's charges against Tchaikovsky shows that they consider exaggerated emotional expression, the bathos typical of this composer, which Dahlhaus considers as 'intrusive', and emotional effusiveness, which he finds 'garrulous'. But these are ways of expressing emotional characteristics, not just of Tchaikovsky's style but of all Russian culture, found in speech intonation, acting, and music performance style (the famous string vibrato), even in the visual arts. In terms of Elizabeth Tolbert's anthropology, these qualities are the socio-emotional essence of Russian culture, a kind of unofficial social contract which defines the verbal and nonverbal ways of expressing emotions ${ }^{462}$. One could just as well see kitsch in the art of the Russian Orthodox Church, since their aesthetics are different from the one that prevails in Prussian Berlin. The anthropological category I refer to determines the forms of music's functioning and reception. It would therefore be reasonable to accept the warning found in another Dahlhaus's text that "it is a mistake to make judgments concerning one manner of existence [of music note by AT] using the norms of another." ${ }^{\prime 63}$

Our claim that Dahlhaus judged the products of one culture using the norms of another may seem exaggerated. After all, his criticism of kitsch concerned one specific work, not the entirety of Russian music. Nevertheless, a closer reading of his Idea of Absolute Music and Studien zur Trivialmusik im 19. Jahrhundert does confirm our suspicions. The Berlin scholar usually discovers kitsch in music from the Slavs, less commonly - the Latin-Romance cultural sphere, and he selects his examples without justifying his choice. He could easily discover melodic and

461 Dahlhaus, "Uber die 'mittlere Musik' des 19. Jahrhunderts", in: Helga de la MotteHaber (ed.) Das Triviale in Literatur, Musik und Bildender Kunst, (Frankfurt am Main: Klostermann, 1972) p. 134, Polish edition: Idea muzyki absolutnej, Kraków: PWM, 1978., p. 474.

462 Elisabeth Tolbert, "Music and Meaning: An Evolutionary Story", Psychology of Music, 2001, Vol. 29, No. 1, pp. 84-94.

463 C. Dahlhaus, “Trivial Music and Aesthetic Judgment”, in: Christopher Washbourne and Maiken Dermo, Bad Music: The Music We love to Hate, (New York-London: Routledge, 2004) p. 345. 
harmonic banality in German music as well, to mention only Schubert's piano pieces or Beethoven's famous 'hit' Für Elise. But he may have considered this as blasphemy, as evident from Dahlhaus's reaction to Hans Georg Naegeli's claims concerning the banality of some harmonic progressions in Mozart's Symphony No. 41 in C Major 'Jupiter', which Dahlhaus rejected as "narrow-minded" because they focus on details disregarding the context. ${ }^{464}$. His own 'expert opinion' concerning the qualities of Tchaikovsky's work could well be rejected on the same grounds.

The only arbitrator in this 'debate of authorities' - Tchaikovsky and Dahlhaus can be the international community of competent listeners (artists-performers, critics, composers and musicologists). But life itself, in the form of global concert repertoires, can solve this conflict. Can we accuse world class conductors and orchestras (not only from a Slavic cultural background) who perform this composition of being deluded by the easy charm of kitsch? Is their artistic taste really less reliable than the sophisticated taste of the Berlin scholar?

\section{From Nationalism to Universalism}

As we come to the end of the 20th century in our study, cases of 'negative selection' of subjects for analysis motivated by national sentiments become rare, which may be the fruit of gradual globalisation. Also the typical repertoire preferences and prejudices of early 20th-century audiences and critics, as exemplified by Artur Rubinstein's report of the French audience's dislike of Brahms and by the German academic music circles' dislike of Debussy - began to disappear. Another sign of progressive international integration is the universal acceptance and application of such theories and composition techniques that originally derived from specific national traditions, and whose authors sometimes represented extreme nationalistic views. The universalisation of those theories and techniques is accompanied by their 'transplantation' into other cultural contexts, the 'acculturation' of their ideological contexts and the demythologisation of the understanding of music traditions that was represented by their creators before World War II.

One typical example of this process is the spectacular career of two Viennese theories from the early 20th century, which, owing to the industry and effectiveness of émigrés from this cultural environment dominated theoretical thought and analytic practice in the most important (English-speaking) musicological

464 Dahlhaus, “Trivial Music and Aesthetic Judgment”, p. 342. 
centres of the contemporary world. These two theories - Schenkerism and (slightly overshadowed by the former) Reti's evolutionism - were distinct from each other but complementary, and essentially based on the same ideological assumptions of looking for a hidden unity behind the apparent multiplicity and diversity of specific manifestations. How is that law of nature that reflects the divine unity of being reflected in music, in which it is a sign of genius? As we know, Schenker saw this unifying principle in the archetypal Ursatz which constituted the harmonic-contrapuntal 'skeleton' of the organisation of the musical work in the period when the tonal system reigned supreme. Reti, on the other hand, focused on cyclic instrumental forms, looking for the unifying combinations of fundamental intervallic cells hidden behind the 'façade' of sound. He shared with Schenker a fascination with musical genius, while the final version of his theory (as frequently stressed in literature of the subject) was largely influenced by another eminent Viennese artist, Arnold Schönberg, and his composition technique based on an evolutionary development of musical discourse by transforming an original idea composed of several simple intervallic cells. The metaphysical foundation of this concept was the dichotomy of unity and multiplicity, the Schönbergian 'unity of musical space'. Serial procedures, writes Marcin Trzęsiok, symbolise the illusory "spatial and temporal" dimensions of reality. "Behind the apparent multiplicity, there is a unity that an ordinary human mind cannot grasp. Each 'point' in time and space already contains the whole in itself." 465

Though the theoretical thought of the above-mentioned Viennese thinkers and Schönberg's composition technique became universal values, they are deeply rooted in the German musical tradition and intellectual reflection, as confirmed by Eero Tarasti's well-known statement concerning speculative German 18th/19th-century philosophy, usually discussed in terms of universal values, which was, nevertheless, a typical product of German intellectual culture of that time: "all this tradition claims to be universal. But we all know that it is essentially German." ${ }^{666}$

465 Marcin Trzęsiok, "Narodziny dodekafonii z ducha teozofii - Schönberg, Swedenborg i metempsychoza" [The Birth of Dodecaphony from the Spirit of Theosophy Schönberg, Swedenborg and metempsychosis], in: Ewa Zając and Marta Szoka (ed.), Kompozytor i jego swiat [The Composer and His World] - Bronisław Przybylski in memoriam, (Łódź:Akademia Muzyczna im. G.K. Bacewiczów, 2012), by p. 43.

466 EeroTarasti, "Portrait of a European Scholar: Eero Tarasti interviewed by Lina Navickaite", Res facta nova, No. 10, PTPN 2008, p. 12. 
According to Joseph Kerman, the strong position of Shenkerian thought in English-speaking countries, especially in the United States, results from the domination of musical life in those countries by the great German musical tradition. Such domination is not observed in Romance countries, which focus on their own traditions ${ }^{467}$. Schenker's frequently quoted pantheon of musical geniuses consists almost entirely of Germans ${ }^{468}$, and his theories were undoubtedly inspired by Hegel and Goethe, which makes Schenkerism a system based on German traditions and analytically confirming those traditions. Does this pantheon prove, however, that Schenker himself was motivated by nationalism? Not more, it seems, than time and place could have influenced his thinking. It was a common view during that period that nature divides talents among races and nations as it does among individuals - unequally. The obvious conclusion was that some nations are more musically gifted than others. Fascinated with the phenomenon of musical genius, Schenker strove to consider the largest possible collection of techniques and strategies of composition found in pieces of music which were then commonly (not only in German culture) considered as works of genius. All the civilised world sought universal values in the music of Bach, Mozart and Beethoven. It seemed, therefore, that the expansion of German music was something natural and that its greatest masters discovered some secret laws that were the key to immortal artistic value, globally and quite above the considerations of historical development. As Pierre Bourdieu observed many years later, each culture demonstrates a socially determined tendency to view its arbitrary forms of order, developed into a canon, as products of the laws of nature ${ }^{469}$. The Schenkerian 'Teutonism' (if I may be allowed to draw again on Maciej Gołąb's terminology) was therefore a spin-off and result of what then seemed as an indisputable fact in Vienna and Berlin - namely, that German music was superior to, and so won the competition with any other music, even in its own territory.

467 Joseph Kerman: "How We Got into Analysis, and How to Get out", Critical Inquiry 1980, Vol. 7, pp. 311-331.

468 The exceptions were Scarlatti and Chopin, but the latter, as German authors frequently emphasise, was educated under the guidance of a Polonised German (Elsner), whose models were mainly Bach and Mozart.

469 Pierre Bourdieu, Outline of a Theory of Practice, transl. by Richard Nice, (Cambridge: Cambridge University Press, 1977), p. 164. See also: Bourdieu, Distinction: A Social Critique of the Judgment of Taste, transl. by Richard Nice, (Cambridge, Massachusetts: Harvard Univeristy Press:1984). 
Schönberg not only saw his own music compositions and theoretical thought as rooted in German musical heritage, but also drew directly on nationalist doctrines popular in the interwar period. Let me refer once again to the statement he made in his essay Nationale Musik (1931): "Remarkably, nobody has yet appreciated that my music, produced on German soil, without foreign influences, is a living example of an art able most effectively to oppose Latin and Slav hopes of hegemony and derived through and through from the traditions of German music..." ${ }^{470}$. Richard Taruskin observes that Schönberg reels off here in one go the names of Bach, Mozart, Beethoven, Brahms, Wagner, Strauss, Reger and Mahler, listing the elements of technique that he owes to them, and then adds - disarmingly and highly characteristically: "I shut myself off from no one." ${ }^{\text {" }}$ Schönberg's quoted statement contains echoes of Volkist and Blut und Boden ideology, and represents a typically nationalist view of one's own culture as a separate universe, which, naturally, is as legitimate a view for an artist to hold as any other. Webern, on the other hand, came close to chauvinism in his exalted praise of Teutonic music. "If we wish to understand philosophy," he taught his students in the 1930s, "we must turn to the ancient Greeks. To know and understand music, we must turn to Haydn, Mozart, Beethoven and other masters of the Austro-German tradition. [...] The music of the greatest composers from other countries is but a faint reflection of the creations of German masters. Berlioz is a French Beethoven, Tchaikovsky - a Russian Schumann, and Elgar - an English Mendelssohn." ${ }^{472}$

Today it is obvious that this vision of tradition conceived as an unbroken line of evolution of sound language from Bach to Schönberg is a myth, just like Schenker's 'epoch of geniuses' - a concept so suggestive that 30 years ago Maria Piotrowska still defended it in "Ruch Muzyczny" magazine in a polemic with Tadeusz Zieliński ${ }^{473}$. It has been proved many

470 A. Schönberg, "National Music (2) 1931”, p. 173.

471 Richard Taruskin, “Alte Musik' or 'Early Music'?” Twentieth-Century Music, Cambridge Univeristy Press, Vol. 8, No. 1, 2011, pp. 3-28.

472 Quoted after: Taruskin, “'Alte Musik'?, p. 17.

473 The author herself did not refer to Schenker's theory in her text, but from the context of her argument it transpires that she considered that Geniezeit as coinciding with the period of the supremacy of functional harmony, and especially with its heyday in the era of Classicism. Zieliński polemically pointed out that talents and geniuses have emerged in different periods of history and in many different places worldwide. Cf. Maria Piotrowska "Harmonika według Zielińskiego" [Harmony According to Zieliński], Ruch Muzyczny, No. 5, 1985, pp. 24-26, Tadeusz A. Zieliński "Geniusze i modele" [Geniuses and Models], Ruch Muzyczny No. 12, 1985, pp. 3-4. 
times $^{474}$ that the German tradition from which Bach and Handel were born ended with them, and the Viennese classics had more in common musically with the Italian opera buffa than with Bach. This tradition was formed more by the community of verbal than musical language, and therefore the myth in question can be counted among Gellner's ${ }^{475}$ cases of 'inventing tradition' to justify historiosophic theses, which in turn sanctioned the nationalist point of view.

It is a great paradox of history and the irony of fate that after 1933 all the abovementioned eminent representatives of the Second Viennese School were pushed outside the margins of the culture that they identified with, that they glorified and described in terms of absolute value. Schenker and Schönberg, as we mentioned before, were banned as 'non-Aryans', accused of the Verfalschung and Vergiftung of the great German tradition, while Webern and Berg were condemned as their Aryan 'passive tools', copying destructive ideas that came from an alien cultural space and so leading their own culture to inevitable degeneration.

The adaptation of Schenker and Schönberg's theoretical thought in the AngloAmerican world seems to have taken the form - again in Jim Samson's terms ${ }^{476}$ - of a 'transplantation' of key theoretical ideas accompanied by gradual 'acculturation' that got rid of their original ideological context. Other famous theories also derived from the same cultural context, such as Freud's psychoanalysis, underwent a similar process. The transformation of Freud's theories on the other side of the ocean, as analysed by Danuta Danek ${ }^{477}$, took a similar and parallel course as the process of 'Americanising Schenkerism' ${ }^{478}$ described by William Rothstein. In both cases, ideological concessions were made to technocracy, academic scientism and pragmatism. In the case of Schenker's theory, this process had two stages:

1. A departure from metaphysics, from axiological subtexts and dogmatic subjectivism of argument in favour of specifying the vague elements of the theory and details of

474 Cf.: D. Heartz, Approaching a History of 18th-Century Music, "Current Musicology" 9, 1969, pp. 92-95; Cf. Taruskin, “'Alte Musik'?”, pp. 17-18.

475 Gellner, Nations and nationalism, p. 72.

476 Jim Samson, "Little Stories from the Balkans", in: Florian Scheding, Eric Levi (eds) Music and Displacement, (Toronto: Lansham, 2010), pp. 181-194.

477 Danuta Danek, Introduction to Gustaw Bychowski’s treatise Słowacki i jego dusza. Studium psychoanalityczne [Słowacki and His Soul. A Psychoanalytic Study] Warsaw 1930, reprinted by: Universitas, Kraków, 2002, p. VI.

478 William Rothstein, “The Americanization of Heinrich Schenker”, in: Hedi Siegel (ed.) Schenker Studies, Cambridge University Press, 1990, pp. 193-203. 
analytic procedure ${ }^{479}$. One of the leading advocates of Schenkerism (and the translator of Schenker's works into English) John Rothgeb, wrote that, though Schenker may have considered his teachings as an integral part of his worldview, it was not logically dependent on his extra-musical speculations ${ }^{480}$. A similar opinion was expressed by the other eminent advocate of the 'Schenkerisation' of America and of 'Americanising' Schenker - Allen Forte ${ }^{481}$.

2. An even more distinct concession to 'typically Anglo-American' pragmatism, consisting in freeing Schenkerism from the dogma of Ursatz and in a fundamental transformations of his theoretical-analytic procedures, whereby his methodology lost its speculative-deductive character in favour of empirical-inductive techniques. In this way, the primacy of musical works from the "epoch of geniuses" was rejected, and the speculations concerning the Ursatz, which in the orthodox version of Schenker's theory determined the direction of all analyses, were replaced by an empirically derived network of linear-vertical nods of sound organisation, considered as the 'structural backbone' of a given piece of music. As we know, this is the direction that post-Schenkerian 'revisionist' methodology was to take.

479 Rothstein lists the verbal oppositions that illustrate the differences between Shenker's rhetoric in its original, Viennese form and its American version. I quote this list below:

Original (Viennese)
poetic
poet
fire
flowery
dogmatic
claim to truth
philosophical
prophet

American
sober
scientist
dispassionate
dryness
objective
scholarly
rationalism
cool taxonomist

Quoted after: Rothstein, “The Americanization ”op. cit., p. 198.

480 Robert Snarrenberg, “Competing Myths: The American Abandonment of Schenker's Organicism", in: Theory, Analysis and Meaning in Music, ed. Anthony Pople, (Cambridge: Cambridge Univeristy Press, 1994), pp. 29-57.

481 David C. Berry notes that elements of Schenker's theory were introduced into the syllabuses of systematic courses of harmony as early as 1925 by a New York theory teacher, George A. Wedle, lecturing at the Institute of Musical Art. Cf. David C. Berry, "Schenker's First 'Americanization': G. Wedle, the Institute of Musical Art. and the 'Appreciation Racket'", Gamut Online Journal of the Music Theory Society of the Mid-Atlantic, 2011, Vol. 4, No. 1, http://trace.tennessee.edu/gamut/vol4/iss1/ accessed: 12.10. 2014 
A similar departure from nationalistically-minded metaphysics and speculations in favour of sober empiricism can be observed in the reception of the ideas of Schönberg and Reti, as exemplified by Alan Walker's empirical studies in which he attempted to prove the truth of the main theses of the evolutionist concept of 'unity-in-multiplicity' ${ }^{\prime 482}$. Walker studied perception on the example of representative groups of professional musicians in order to prove the key role of subconsciously perceived 'organic unity' in forming value judgments.

482 Alan Walker, A Study in Musical Analysis, London: Barrie and Rockliff, 1962. 



\section{Conclusion}

The above described migrations of theoretical thought, accompanied by inevitable concessions and transformations in its original ideological base, considered anachronous in the second half of the 20th century, were undoubtedly a signum temporis and a symptom of growing European integration. As mentioned above, many postwar composers drew more or less consciously on their respective national heritage and confirmed their genuine patriotism with both their music and their lives. Both brilliant contemporaries born in 1913, Witold Lutosławski and Benjamin Britten, were undoubtedly patriotically minded. Despite his resentment toward communism, which badly affected his family, Lutosławski never considered emigration. In the 1950s this may also have had to do with a pragmatic and realistic attitude. He knew the fate of Roman Palester and other émigrés who, deprived of the Polish state's protection, had to struggle in order to survive in the world of art. On the other hand, Lutosławski did not leave Poland also in later times, when he was already a world-famous composer and his country was still ruled by a regime whose ideology he never came to accept. Britten - as we have mentioned - despite his pacifist views returned to England in 1942, risking his life at the most dramatic moment of the country's struggle for survival. Moreover, as a homosexual he was returning to a country in which the law had criminalised homoerotic relations. Both composers were born and died in their fatherland and their homelands - Britten in Suffolk, Lutosławski in Warsaw. Their music, attitudes and life philosophies prove that they were heirs to their respective national traditions. When we compare their statements, however, we can observe just how much they differed from the views presented in the interwar period by their predecessors - Szymanowski and Vaughan Williams. Though Britten did agree with the latter that rooting in a culture is crucial to an artist, and applied this view also to himself, one can hardly find in his statements any fear of competition from the musical traditions of other nations or any suggestions of a cultural 'alliance' against the real or imagined hegemony of other cultures. Also in Szymanowski's writings we can find mention of such 'defensive alliances' between Slavic and Romance-Latin artists to oppose German domination. The 'openness' of Szymanowski's and Vaughan Williams's respective nationalisms (to refer to Kohn's classifications again) was evidently relative or selective and depended on the current political situation, aesthetic stance and recent fascinations. On the other hand, a similar though most sharper rhetoric of 'policy and war' can also be found in those statements from the interwar period 
that represent a 'closed' type of nationalism or even chauvinism. Schönberg defends the privileged position of his culture from the perspective of traditional hegemony, and boasts that his music effectively opposes the expansion of LatinRomance and Slavic cultures. Webern, who was not afraid of their expansion, spoke from the position of condescending superiority about the derivative character of music by foreign masters, who, he claims, borrowed from 'the only genuine' great tradition - the German one. Apart from the aggressive rhetoric of the 'incessant struggle in the field of spirit' and hegemonic ambitions of Nazi writers, we should also consider in this context the reception of Respighi's Roman Trilogy in prewar Italy, the above-quoted reviews and analyses of his work (though the composer himself did not write on these subjects), which represent the same view of nationalism as the one formulated by Balicki in his above-quoted definition of 1912. This Polish National Democratic activist postulated - as an indispensable condition of transforming patriotism into nationalism - "a central idea that would systematically aim at achieving certain aims with the view of a nation's defence, reinforcement and expansion." This "central idea," transplanted into the field of music and of culture in general became a distinguishing characteristic of all types of nationalism in the first three decades of the 20th century.

Did this 'defensive-offensive' type of nationalism come to an end together with World War II? At present, the progressing globalisation and integration of European nations (in the spirit of Vaughan Williams) suggest that this nationalist ideology is a thing of the past, and that contemporary political culture, by respecting all traditions as civilizational heritage, has definitely disposed of such forms of public discourse on music as those presented in this book. Possibly the lack of the need to 'defend, reinforce and expand' will lead to the formation of a modern equivalent of nationalism suited to present-day conditions of international coexistence, to the existing economic-political and cultural structures. It is even possible that a new European identity (or even 'nationality') will emerge, for which Poland, Germany and Italy will be just regions of one common fatherland in the same sense, in which the Crown, Lithuania and Samogitia were parts of one Polish-Lithuanian Commonwealth. On the other hand, the above mentioned 'fluctuations' similar to those described by Maciej Gołąb for modernism in art are still possible, and today's 'ebb' may be followed a 'high tide', especially if a global empire revives the rhetoric of 'reinforcement and expansion', translating it into expansive economic, military and cultural policies, which may inevitably provoke other countries to take a 'defensive' stance. A return of 'open', 'positive' nationalisms is still also possible - in such forms and attitudes toward other cultures as those represented by Polish Romanticism and expressed in the artistic-spiritual form in Chopin's music, in the verbal-ideological form 
by Mickiewicz (his address to 'the Muscovite friends', alliance with Mazzini, the concept of fighting 'for your and for our freedom'), by Czartoryski (the idea of international solidarity), Cieszkowski and Libelt (each nation is created by God, and it is therefore our duty to respect each nation). Such openness and a generous attitude toward other nations, as can be found in the national Romantic thought of Poles, Italians and Germans, could revive a more positive understanding of the concept of 'nationalism', provided it takes root in social consciousness and obliterates the heritage of the 'closed' nationalisms of the interwar period and their political aftermath. Whether this really happens in the future, however, is beyond our capacity to predict. 



\section{Bibliography}

\section{Primary Sources}

Auden, Wystan H., "Psychology and Art To-day.", In: The Arts To-day, Geoffrey Grigson (ed.), London: Bodley Head, 1935, pp. 1-21.

Balicki, Zygmunt, Egoizm narodowy wobec etyki, Lwów: Towarzystwo Wydawnicze, 1903.

Balicki, Zygmunt, "Nacjonalizm a patriotyzm." Przegląd Narodowy, No. 5, May 1912, pp. 449-457.

Bastianelli, Giannotto, La crisi musicale europea, Pistoia: Pagnini, 1912.

Bell, Michael, "Music in Nazi Germany," The Musical Times, Vol. 79, No. 1140, Feb. 1938, pp. 99-101.

Berl, Heinrich, Das Judentun in der Musik, Stuttgart: Deutsche Verlags-Anstalt, 1926.

Blessinger, Karl, Die musikalische Probleme der Gegenwart und ihre Lösung, Stuttgart: Filser Verlag, 1919.

Blessinger, Karl, Judentun und Musik - Ein Beitrag zur Kultur- und Rassenpolitik, Berlin: Hahnefeld, 1944.

Capell, Richard, “The Florence Festival.” Monthly Musical Record, LXIV, May 1934, p. 83.

Cooke, Arnold, “The International Music Festival in Florence." The Chesterian, May-June 1934, p. 137.

Chamberlain, Houston S., Die Grundlagen des XIX Jahrhunderts, München: Bruckmann, 1900.

Chamberlain, Houston S., Richard Wagner, Sechste Auflage, München: Bruckmann, 1919.

Chase, Gilbert, "The State and the Fine Arts in France”, The Musical Times, Vol. 75, No. 1101, Nov. 1934, pp. 977-980.

Claus, Ludwig F., Die Nordische Seele, München: Lehmann, 1936.

Cogni, Giulio, “Razza e musica." Difesa della razza, Nos. 5- 11, 1942: No. 5, pp. 10-12, No. 8, pp. 9-11, No. 9, pp. 9-10, No. 10, pp. 14-16, No. 11, pp. 17-18.

Czekanowski, Jan, Zarys antropologii, Lwów: Lwowska Biblioteka Slawistyczna, 1930.

Dahlhaus, Carl, “Über musikalischen Kitsch”, In: Studien zur Trivialmusik im 19. Jahrhundert, Carl Dahlhaus (ed.), Regensurg: Gustav Bosse, 1972, pp. 63-67. 
Dahlhaus, Carl, “Über die 'mittlere Musik' des 19. Jahrhunderts.” In: Das Triviale in Literatur, Musik und Bildender Kunst, Helga de la Motte-Haber (ed.), Frankfurt am Main: Klostermann, 1972, pp. 131-147.

Dahlhaus, Carl, “Trivial Music and Aesthetic Judgment.” In: Bad Music: The Music We love to Hate, Christopher Washbourne, Maiken Dermo (eds.), New York-London: Routledge, 2004, pp. 341-362.

Dallapicola, Luigi, “The Genesis of the Canti di Pigonia and Il prigioniero; An Autobiographical Fragment.” Musical Quarterly, Vol. 39, No. 3, 1953, pp. 355-372.

Dallapicola, Luigi, "Prime composizioni corali (1961). Postscriptum, 29th January 1962”, Quoted after: M. Sala, “Preface.” In: Music and Propaganda in the Short Twentieth Century, Massimiliano Sala (ed.), Turnhout: Brepols, 2014, p. IX.

Dmowski, Roman, Myśli nowoczesnego Polaka, Kraków: Towarzystwo Wydawnicze, 1904.

Dmowski, Roman, “Szowinizm”, In: Dmowski, Pisma, Vol. 3 Dziesięć lat walki, Częstochowa: Antoni Gmachowski i S-ka, 1938.

Donadoni Omodeo, Miriam, Giannotto Bastianelli, Lettere e documenti editi e inediti, Vol. 2, Firenze: Leo S. Olschki, 1989-1992.

Eichenauer, Richard, Musik und Rasse, München: Lehmann, 1937.

Einstein, Alfred, “The Present State of Music in Germany." The Musical Times, Vol. 74, No. 1089, November 1933, pp. 977-978.

Fleetwood, Nancy, "Musical Notes from Abroad: Germany." The Musical Times, Vol. 75, No. 1096, June 1934, p. 555.

Fleetwood, Nancy, "Musical Notes from Abroad: Germany." The Musical Times, Vol. 75, No. 1097, 1934, p. 655.

Fleetwood, Nancy, "Musical Notes from Abroad: Germany." The Musical Times, Vol. 76, No. 110, August 1935, p. 749.

Fleetwood, Nancy, "Musical Notes from Abroad: Germany." The Musical Times, Vol. 78, No. 1138, December 1937, p. 1073.

Fleetwood, Nancy, "Musical Notes from Abroad: Germany." The Musical Times, Vol. 79, No. 1142, April 1938, p. 305.

Fuhrmann, Heinz, “Zum Tonkünstlerfest 1937 des Allgemeinen Deutschen Musikvereins in Frankfurt a.M. und Darmstadt." Niedersächsische Tageszeitung (Hannover), Nr. 136, 15 June 1937, quoted after: Kohler, Grey C, Acceptable, pp. 157-158.

Gasco, Alberto, “I Pini di Roma del m.o Respighi." La tribuna, 16th December 1924, quoted after: Flamm, “<Tu, Ottorino,>”, p. 347. 
Gerigk, Herbert, "Problematisches Opernwerk auf dem

Tonkünstlerfest:,,Carmina Burana“ von Carl Orff.” Völkische Beobachter (Berliner Ausgabe), Nr. 167, 16 June 1937, p. 5.

Gerigk, Herbert, “Schweigen die Musen?” Musik im Kriege, II/7-8, 1944, pp. 121-122.

Gerlach, Kurt, Begabung und Stammesherkunft im deutschen Volke. Feststellungen über die Herkunft der deutschen Kulturschöpfer in Kartenbildern, München: Lehmann 1929.

(anon.) G.F.D. "Letters to the Editor: 'Music in Nazi Germany"' The Musical Times, Vol. 79, No. 1142, April 1938. pp. 286-287.

Gobineau, Joseph A. de, Esai sur l'inegalite des races humaines, Paris: FirminDidot fréres, 1853.

Goebbels, Joseph, “Zehn Grundsätze deutschen Musikschaffens.” Amtliche Mitteilungen der Reichsmusikkammer, Vol. 5, No. 11, 1938.

Goldbeck, Fred, "La musique dans l'exposition internationale de 1937." Numero special de la Revue Musicale, 1937.

Grabowski, Zygmunt, "Niemcy po przewrocie." Życie sztuki, No. II, 1935, pp. 286-339.

Graf, Otto, “Organizacja życia muzycznego w Niemczech.” Muzyka Polska, VI, 1935, pp. 113-126.

Gross, Walter, Der Rassengedanke im neuen Geschichtsbild, Berlin: Junker und Dünnhaupt, 1936.

Günther, Hans, Rasse und Stil, München: Lehmann, 1926.

Günther, Hans, Rassenkunde des deutschen Volkes, München: Lehmann, 1930.

Henderson, Neville, Failure of a Mission: Berlin 1937-1939, New York: G.P. Putnam's Sons, 1940.

Hlond, August, List pasterski 'O katolickie zasady moralne’, Poznań: Ośrodek Postulatorski Towarzystwa Chrystusowego, 29 Feb.1936, www.patrymonium. chrystusowcy.pl.

Huntington, Elsworth, "Exploding the Idea of Race." The Saturday Review, 29 Feb.1938, p. 5.

Huxley, Julian and Haddon, Alfred C., We Europeans: A Survey of "Racial" Problem, London: Cape, 1935.

Korolec, Jan, "Czy slowo zaklęcia będzie powiedziane po polsku?” Prosto z mostu, No. 3, 1935, p. 4.

(anon.) "Kronika." Muzyka, No. 3 (113), 1934, p. 136.

(anon.) "Kronika - Niemcy: Nowe hasła." Muzyka Polska, No. I, 1936, pp. 80-84. 
(anon.) "Kronika - Włochy." Muzyka Polska, No. I, 1936, p. 80.

(anon.) “Kronika - Włochy.” Muzyka Polska, No. IV, 1936, p. 368.

(anon.) "Kronika - Niemcy." Muzyka Polska, No. II, 1939, p.106.

(anon.) "Kronika - Niemcy." Muzyka Polska, No V, 1938, p. 249.

(anon.) “Kronika - Grecja." Muzyka Polska, No. II, 1939, p. 106.

(anon.) "Kronika - Włochy." Muzyka Polska, No. II, 1939, p. 106.

Lagarde, Paul de, Deutsche Schriften, Göttingen: Dieterich, 1878.

Langbehn, Julius, Rembrandt als Erzieher, Leipzig: Hirschfeld, 1900.

Lexikon der Juden in der Musik, ed. Theo Stengel, Herbert Gerigk, Berlin, 1944.

Libelt, Karol, O miłości ojczyzny, Brody: Feliks West, 1907.

Lissa, Zofia, "Problem rasy w muzyce." Muzyka, No. 3 (113), 1934, pp. 108-112.

Lissa, Zofia, W sprawie rasy Fryderyka Chopina, “Wiadomości literackie”, No. 778, 1938, p. 7.

Lockspeiser, Edward, (review) “'Musik und Rasse' by Richard Eichenauer." Music and Letters, Vol. 11, No. 2, Apr. 1933, pp. 185-186.

Ludwig, Emile, Talks with Mussolini, London: G. Allen \& Unwin, 1932.

Marylski, Antoni, Dzieje sprawy żydowskiej w Polsce, Warszawa: Gebethner i Wolff, 1912.

Matzke, Herman, Über Deutschen Musikausdruck und deutsche Musikpflege, Breslau: Hoppe, 1933.

Matzke, Herman, Wege zu deutscher Hausmusik, Breslau: de Wit, 1936.

Meissner, Max, "Stosunki muzyczne w Trzeciej Rzeszy.” Muzyka, No. 3 (113), 1934, pp. 125-126.

Melchiorre, Nicola, "Respighi ed i sui poemi." Larte fascista, III/10-11, 1928, pp. 398-400.

Mieses, Mateusz, Polacy-chrześcijanie pochodzenia żydowskiego, Warszawa: Wydawnictwo M. Fruchtmana, 1938.

Mochnacki, Maurycy, O literaturze polskiej w wieku XIX, Kraków: Krakowska Spółka Wydawnicza, 1923.

Mostra, "La difesa della razza" - ideologia e applicazione delle leggi anti-ebraice all' Universita di Torino, 1938-1943, Archivio Storico Universita degli Studi di Torino, 2010: http://www.istoreto.it/materiali/Leggi\%20razziali/doc/794_ Difesa_della_razza.pdf, accessed: 08.05.2019.

Mussolini, Benito, Doktryna faszyzmu, trans. Stanisław Gniadek, Lwów: Filomata, 1935.

Müller-Blattau, Josef, Germanisches Erbe in deutscher Tonkunst, Berlin: Vieweg \& Teubner, 1938. 
(anon.) F.B. "Modern Music at Venice." The Musical Times Vol. 78, No. 1136, Oct. 1937, p. 914.

(anon.) (M.D.C.) review: “"Musik und Rasse' by Richard Eichenauer.” The Musical Times, Vol. 75, No. 1091, p. 40.

(anon.) "Musical Notes from Abroad - Italy." The Musical Times, Vol. 78, No. 1128, Feb. 1937, p. 170.

(anon.) "Notes of the Day." The Monthly Musical Record, No. LXIII, May 1933, p. 78. Nowaczyński, Adolf, "Italia i Polonia." Prosto z mostu, No. 34, 20 Aug. 1939, p. 8.

Oboussier, Robert, "Der schaffende Musiker in neuen Deutschland. Erster deutscher Komponistentag." Deutsche Allgemeine Zeitung, 19 Feb. 1934, quote after: Garberding, "We Take Care", p. 7.

Paderewski, Ignacy J. “Myśli, uwagi, refleksje.” Muzyka, No. 2 (112), 1934, pp. 49-51.

Pessenlehner, Robert, Wom Wessen der Deutschen Musik, Regensburg: Bosse, 1937.

Przybyszewski, Stanisław, Szopen a naród, Kraków: Spółka Nakładowa "Książka”, 1910.

Przybyszewski, Stanisław, Szlakiem duszy polskiej, Poznań: Spółka Nakładowa "Ostoja”, 1917.

Quidam, “O Polakach pochodzenia żydowskiego.” Wiadomosci Literackie, No. 774, 1938, p. 6.

Raabe, Peter, Die Musik im dritten Reich, Regensburg: Bosse, 1935.

Rauschning, Hermann, The Voice of Destruction, New York: G. P. Putnam's Sons, 1949.

Raynor, Henry B. and Stevens, Robert, "Letters to the Editor - Fascism and Ministry of Fine Arts." The Musical Times, Vol. 75, No 1098, Aug. 1934, pp. 737-738.

Reiss, Józef, “Dusza żydostwa w muzyce.” Muzyk Wojskowy, Nos. 9-14, 1928: No 9, pp. 1-4, No 10, pp. 2-3, No 11, pp. 2-3, No 13, pp. 1-2, No 14, pp. 1-2.

Rensis, Raffaello de, Mussolini musicista, Mantua: Edizioni Paladino, 1927.

Reusch, Fritz, Musik und Musikerziehung im Dienste der Volksgemeinschaft, Berlin: Zickfeldt, 1938.

Rock, Christa and Brückner, Hans, Judentum und Musik: mit dem ABC judischer und nichtarischer Musikbeflissener, München: Hans Brückner, 1936.

Rossi, Nino, 'Pini di Roma.' il Resto di Carlino, 5 June 1925, quote after: Flamm, “Tu, Ottorino”, pp. 347-348.

Russel, Thomas A., "Letters to the Editor: Music in Nazi Germany." The Musical Times, Vol. 79, No. 1141, March 1938, p. 216. 
Sachs, Julius, Der Jüdische Musikalien - Katalog: Die wichtigsten Werke Jüdischer Komponisten, Breslau: Brandreis, 1936.

Schemann, Ludwig, Rasse in den Geistwissenschaften, München: Lehmann, 1930.

Schönberg, Arnold, "National Music.” In: idem: Style and Idea, Leonard Stein (ed.), Los Angeles: University of California Press, 1984.

Schroeder, Christa, He Was My Chief: The Memoirs of Adolf Hitler's Secretary, trans. Geoffrey Brooks, Barnsley, Yorkshire: Frontline Beeks, 2012.

Schulze-Naumburg, Paul, Kunst und Rasse, München, Lehmann, 1935.

Sergi, Giuseppe, The Mediterranean Race: A Study of the Origins of European Peoples. London: Walter Scott, 1901.

Shaw, George B., “The Future of British Music.” The Outlook, 19th July 1919. Quoted after: Louis Crompton (ed.), The Great Composers. Reviews and Bombardments by Bernard Shaw. Berkeley: University of California Press, 1978, pp. 356-362.

Siegmund-Schultze, Walther, "Theorie und Methode des sozialistischen Realismus in der Music.” In: Handbuch der Musikaesthetik, S. Bimberg (ed.), Leipzig, 1979.

Stege, Fritz, "Die Reinigung des deutschen Opernspielplans." Zeitschrift fur Musik, Jahrgang 100, 1933, pp. 487-488.

Stege, Fritz, "Der Deutsche Komponistentag." Der Berliner Westen, 19 Feb. 1934, Quoted after: Garberding, "We Take Care of the Artist", p. 8.

Stege, Fritz, statement in: "Volkische Musikerziehung. Monatschrift für das Musikerziehungsweise”, III, 1936, quote after: Wulf, Musik im Dritten Reich, p. 247.

Stege, Fritz, "Die gegenwartige Lage der deutschen Musik." La Revue Internationale de Musique, Vol. 1, No. 1, March-April 1938, pp. 77-84.

Stengel, Theo and Gerigk Herbert (eds.), Lexikon der Juden in der Musik, Berlin: Hahnefeld, 1944.

Szymanowski, Karol, In: Pisma muzyczne, Kornel Michałowski (ed.), Kraków: PWM, 1984.

Szymanowski, Karol, Pisma literackie, Teresa Chylińska (ed.), Kraków: PWM, 1989.

Tippett, Michael, Those Twentieth Century Blues: An Autobiography, London: Hutchinson, 1991.

VaughanWilliams, Ralph, National Music and Other Essays, Oxford: OUP, 1987. Vaughan Williams, Ralph, "Who Wants an English Composer?" RCM Magazine, Vol. IX No. 1, 1912, quoted after: Manning ed. Vaughan Williams on Music, p. 41. 
Walldorf, Jerzy, “Totalistyczne impresje.” Muzyka Polska, No. 2, 1939, p. 76.

Wieniewski, Ignacy, "Habend sua fata - insignia." Filomata, Lwów, No. 101, 1938, pp. 527-531.

Woltmann, Ludwig, Die Germanen und die Renaissamce in Italien, Leipzig: Thüringische Verlagsanstalt, 1905.

Wójcik-Kepreulian, Bronisława, (review) "Richard Eichenauer 'Musik und Rasse.” Kwartalnik Muzyczny, Nos. 19-20, 1933, pp. 172-176.

Zbyszewski, Karol, “Blok zdrowego sensu." Prosto z mostu, No. 39, 1938, p. 8.

(anon.) “Ze świata.” Muzyka Polska, January 1936, p. 78, March 1936, p. 30, May 1936, p. 428.

(anon.) "Żydowskie kasy bezprocentowe stwarzają konkurencję polskiemu rzemiosłu." Dziennik Narodowy. No. 52, Poznań 21st August 1935, p. 5.

\section{Secondary Sources}

Adams, Byron, "Scripture, Church and Culture: Biblical Texts in the Works of Ralph Vaughan Williams." In: Vaughan Williams Studies, Alain Frogley (ed.), Cambridge: Cambridge University Press, 1996, pp. 99-117.

Alaimo, Vincenzo, "La razza in musica nel ventennio fascista." In: Italian Music during the Fascist Period, Roberto Illiano (ed.), Turnhout: Brepols, 2004, pp. 225-252.

Arendt, Hannah, The Origins of Totalitarianism, San Diego-New York- London: Harcourt, Brace \& World, 1979.

Assmann, Jan, "Kultura pamięci." In: Pamięć zbiorowa i kultura, Wspótczesna perspektywa niemiecka, Magdalena Saryusz-Wolska (ed.), Kraków: Universitas, 2009, pp. 59-100.

Assmann, Jan and Czaplicka, John, "Collective Memory and Cultural Identity." New German Critique, No. 65, Spring-Summer, 1995, pp. 125-133.

Bailey, Robert W., Performing for the Nazis: Foreign Musicians in Germany, 1933-1939, MA diss. University of Calgary, Alberta, 2015, https://prism. ucalgary.ca.

Barkan, Elazar, The Retreat of Scientific Racism: Changing Concepts of Race in Britain and the United States between World Wars, Cambridge: Cambridge University Press, 1992.

Bent, Ian, "Heinrich Schenker, Chopin and Domenico Scarlatti." Music Analysis, Vol. V, No. 2-3, 1986, pp. 131-149.

Berry, David C., 'Schenker's First 'Americanization': G. Wedle, the Institute of Musical Art. and the 'Appreciation Racket", Gamut Online Journal of the 
Music Theory Society of the Mid-Atlantic, 2011, Vol. 4, No. 1, http://trace. tennessee.edu/gamut/vol4/iss1/ accessed: 12.10. 2014.

Bilica, Krzysztof, “'Boże coś Polskę’ Felińskiego-Kaszewskiego. Inspiracje i echa." In: Pieśń polska, Mieczysław Tomaszewski (ed.), Kraków: Akademia Muzyczna, 2002, p. 197-221.

Bourdieu, Pierre, Outline of a Theory of Practice, transl. by Richard Nice, Cambridge: Cambridge University Press, 1977.

Budden, Julian, Puccini. His Life and Work, Oxford: OUP, 2005.

Carpenter, Humphrey, Benjamin Britten. A Biography, London: Faber and Faber, 1992.

Ciesielski, Rafał, Refleksja estetyczna w polskiej krytyce muzycznej okresu międzywojennego, Poznań: PTPN, 2005.

Cobbe, Hugh, "Vaughan Williams, Germany, and the German Tradition: A View from the Letters." In: Vaughan Williams Studies, Alain Frogley (ed.), Cambridge: Cambridge University Press, 1996, pp. 81-98.

Czekalski, Tadeusz, Pogrobowcy Wielkiej Idei. Przemiany społeczne w Grecji w latach 1923-1940, Kraków: Historia Iagiellonica, 2007.

Dahlhaus, Carl, “The Esthetics of Feeling and Metaphysics." In: The Idea of Absolute Music, Carl Dahlhaus (ed.), Chicago and London: University of Chicago Press, 1989.

Danek, Danuta, "Introduction." In: Słowacki i jego dusza. Studium psychoanalityczne, Gustaw Bychowski (ed.), Warszawa, 1930, reprint: Kraków: Universitas, 2002, pp. I-VI.

Dennis, David B., Beethoven in German Politics, 1870-1989, New Haven and London: Yale University Press, 1996.

Dennis, David B., War on Modern Music and Music in Modern War: Voelkischer Beobachter Reception of 20th Century Composers, Chicago: Loyola University, 2010, p. 7, https://ecommons.luc.edu/history_facpubs/28/, access date: 10.11.2018.

Dennis, David B., Inhumanities: Nazi Interpretations of Western Culture, New York: Cambridge University Press, 2012.

Dümling, Albrecht, and Girth, Peter, (eds.). Entartete Musik: eine kommentierte Rekonstruktion, Düsseldorf: Servicedruck Kleinherne, 1988.

Dziadek, Magdalena, Polska krytyka muzyczna w latach 1890-1914. Koncepcje $i$ zagadnienia, Katowice: Wydawnictwo Uniwersytetu Śląskiego, 2002.

Dziadek, Magdalena, "Karol Szymanowski as Chancellor of the Higher School of Music In Warsaw. New Facts, New Light." In: Karol Szymanowski: Works - Reception - Contexts, Zofia Helman (ed.), "Musicology Today”, Musicology 
Section of the Polish Composers' Union, Institute of Musicology, University of Warsaw, 2008, pp. 94-117.

Earle, Ben, Luigi Dallapicola and Musical Modernism in Fascist Italy, Cambridge: CUP, 2013.

Erhardt, Ludwik, Igor Strawiński, Warszawa: PIW, 1978.

Evans, Joan, "Stravinsky's Music In Hitler's Germany," Journal of the American Musicological Society, No. 56, 2003, pp. 525-594.

FitzGibbon, Katherine, Deutsches Heldenrequiem: Secular Requiem in the Third Reich as an Extension of German tradition, paper delivered at the international conference State Music and Dictatorship, Paris, EHESS, 14-16 May 2009.

FitzGibbon, Katherine, “Gottfired Müller's Deutsches Heldenrequiem (1934): Nazi Ideology Cloaked in Historic Style." In: Composing for the State. Music in Twentieth-Century Dictatorships, Esteban Buch, Igor Contreras Zubillaga, Manuel Deniz Silva (eds.), Abingdon: Ashgate, 2016, pp. 70-82.

Flamm, Christoph, $<\mathrm{Tu}$, Ottorino, scandisci il passo delle nostre legioni $>$. Respighis "Romische Trilogie" als musikalisches Symbol des Italienischen Fascismus? In: Italian Music in the Fascist Period, Roberto Illiano (ed.), Turnhout: Brepols, 2004, pp. 331-370.

Friedrich, Carl and Brzeziński, Zbigniew, Totalitarian Dictatorship and Autocracy, New York: Harvard University Press, 1961.

Friedrich, Carl and Brzeziński, Zbigniew, Totalitarian Dictatorship and Autocracy, New York: Harvard University Press, 1961.

Frogley, Alain, "Constructing Englishness in Music: National Character and the Reception of Ralph Vaughan Williams." In: Vaughan Williams Studies, Alain Frogley (ed.), Cambridge: Cambridge University Press, 1996, pp. 1-22.

Fromm, Erich, Escape from Freedom, New York: Holt, 1941.

Garberding, Petra, "We Take Care of the Artist': The German Composers' Meeting in Berlin, 1934." Music \& Politics, Vol. 3, No. 2, Summer 2009,https:// quod.lib.umich.edu/m/mp/9460447.0003.204/--we-take-care-of-theartist-the-german-composers-meeting? $r g n=$ main;view=fulltext, accessed 12.05.2019.

Geisler, Ursula, "Political Music Censorship: Some Remarks on Nazi Music Regulations 1933-1945." Danish Musicology Online Special Edition, 2015, pp. 77-89, http://www.danishmusicologyonline.dk.

Gellner, Ernest, Nations and Nationalism, Oxford: Blackwell, 1983.

Germino, Dante L., The Italian Fascist Party in Power: A Study in Totalitarian Rule, Minneapolis: University of Minnesota, 1959. 
Giardina, Andrea, “The Fascist Myth of Romanity." Estudos Avancados, Vol. 22, No. 62, 2008, pp. 55-76.

Gilette, Aaron, Racial Theories in Fascist Italy, London: Routledge, 2002.

Gołąb, Maciej, "Analiza i dzieło." Muzyka, No. 4, 1986, pp. 25-41.

Gołąb, Maciej, Józef Michał Chomiński. Biografia i rekonstrukcja metodologii, Wrocław: Wydawnictwo UWr, 2008.

Gołąb, Maciej, Musical Modernism in the Twentieth Century. Between Continuation, Innovation and Change of Phonosystem, Frankfurt am Main: Peter Lang, 2015.

Grunberger, Richard, A Social History of of the Third Reich, London: Weidenfeld\&Nicolson, 1971.

Grynberg, Karol and Otręba, Bolesław, Joachim von Ribbentrop, Warszawa: Książka i Wiedza, 1995.

Halbwachs, Maurice, On Collective Memory, ed. by and transl. by Lewis A. Coser, Chicago and London: The University of Chicago Press, 1992.

Halczak, Bogdan, "Cele polityki endeckiej wobec mniejszości żydowskiej w Polsce w latach 1919-1939.” Biuletyn Żydowskiego Instytutu Historycznego, Nos. 3/95-2/96, pp. 37-47.

Halczak, Bogdan, "Stosunki polsko-niemieckie w publicystyce obozu narodowego w latach 1922-1939." Przeglad Zachodni, No. 3, 1995, pp. 118-127.

Hall, John A., "Nationalisms: Classified and Explained." Deadalus, Summer 1993, No. 3, pp. 1-28.

Hanau, Ewa, "Die musikalischen Aktivitäten des Jüdischen Kulturbundes in Frankfurt am Main.” In: Verfemte Musik, Joachim Braun and others (eds.), Frankfurt am Main: Peter Lang, 1995, pp. 79-91.

Helgason, Hallgrimur, "Leifs Jon." Musik in Geschichte und Gegenwart, Vol. 10, 2003, pp. 1523-1524.

Helman, Zofia, "Karol Szymanowski's Songs in tne Literary and Musical Context of His Times." In: The Songs of Karol Szymanowski and His Contemporaries, Zofia Helman, Teresa Chylińska, Alistair Wightman (eds.), Los Angeles: Polish Music Center at University of Southern California, 2002, pp. 1-10.

Helman, Zofia, "Dylemat muzyki polskiej XX wieku - styl narodowy czy wartości uniwersalne?” In: Dziedzictwo europejskie a polska kultura muzyczna $w$ dobie przemian, Anna Czekanowska (ed.), Kraków: Musica Iagellonica, 2005, pp. 175-200.

Helman, Zofia, "Émigrés by Choice." Musicology Today, Vol. 8, 2011, pp. 5-25.

Hobsbawm, Eric J., Nations and Nationalism since 1780: Programme, Myth, Reality, Cambridge: Cambridge University Press, 1990. 
Hynes, Samuel, The Auden Generation - Literature and Politics in England in the 1930s, London: Faber and Faber, 1979.

Illiano, Roberto and Sala, Massimiliao, "Italian Music and Racial Discourses during the Fascist Period." In: Western Music and Race, J. Brown (ed.), Cambridge: CUP, 2007, pp. 182-200.

Illiano, Roberto and Sala, Massimiliano, "The Politic of Spectacle: Italian Music and Fascist Propaganda." Musikologija/Musicology, Vol. XIII, 2012, pp. 9-26.

Jonca, Karol, "Noc kryształowa" i casus Herschela Grynszpana, Wrocław: Wydawnictwo Uniwersytetu Wrocławskiego, 1998.

Kater, Michael H., "Carl Orff in Dritten Reich." Vierteljahrshefte für Zeitgeschichte, Vol. 43, No. 1, January 1995, pp. 1-35, ifz-muenchen.de.

Kater, Michael H., The Twisted Muse: Musicians and Their Music in the Third Reich, Oxford: Oxford University Press, 1997.

Kater, Michael H., Composers of the Nazi Era - Eight Portraits, Oxford: Oxford University Press, 2000.

Kerman, Joseph, "How We Got into Analysis, and How to Get out." Critical Inquiry, Vol. 7, 1980, pp. 311-331.

Kohn, Hans, The Idea of Nationalism. A Study in its Origins and Background, New York: The Macmillan Company, 1947.

Kohn, Hans, The Mind of Germany. The Education of a Nation, New York: Charles Scribner's Sons, 1960.

Kohn, Hans, Reflections on Modern History, Princeton: Van Nostrand Company, 1963.

Kohler, Andrew S., “Grey C', Acceptable”: Carl Orff's Professional and Artistic Responses to the Third Reich, PhD diss. University of Michigan, 2015, http:// deepblue.lib.umich.edu/bitstream/2027.42/111359/1/askohler.

Köhler, Joachim, Wagner's Hitler - the Prophet and his Disciple, English trans.: Ronald Taylor, Oxford: Polity, 2001.

Levi, Eric, Music in the Third Reich, New York: St. Martin's Press, 1994.

Levi, Eric, "The Reception of Contemporary Italian Music in Britain during the Fascist Period." In: Italian Music during the Fascist Period, Roberto Illiano (ed.), Turnhout: Brepols, 2004, pp. 3-40.

Levi, Eric, "Appeasing Hitler? Anglo-German Music Relations, 1933-1939.” In: Music and Propaganda in the Short 20th Century, Massimiliano Sala (ed.), Turnhout: Brepols, 2014, pp. 19-36.

Levi, Eric, “'Those Damn Foreigners': Xenophobia and British Musical Life during the First Half of the Twentieth Century." In: Twentieth-Century Music 
and Politics, Pauline Fairclough (ed.), London and New York: Routledge, 2016, pp. 81-96.

Levi-Strauss, Claude, The View from Afar, English transl. by Joachim

Neugroschel and Phoebe Hoss, Chicago: University of Chicago Press, 1992.

Macaluso, Alessia A. E., Fascist Disenchantment and the Music of Goffredo

Petrassi, PhD diss., Toronto: York University, 2017 https://yorkspace.library. yorku.ca, accessed: 10.12.2018.

Maffina, Gianfranco, Luigi Russolo e l'arte dei rumori, Torino: Martano, 1978.

Malvano, Laura, Fascismo e politica dell'immagine, Torino: Bollati Boringhieri, 1988.

Martin, Benjamin G., The Nazi-Fascist New Order for European Culture, Cambridge: Harvard University Press, 2016.

McClatchie, Stephen, "Wagner Research as 'Service to the People': The RichardWagner Forschungsstätte 1938-1945." In: Music and Nazism: Art under Tyranny, 1933-1945, Michael H. Kater, Albrecht Riethmuller (eds.), Laaber: Laaber Verlag, 2003, pp. 150-159.

Micewski, Andrzej, Roman Dmowski, Warszawa: Verum, 1971.

Mitchell, Donald, Britten and Auden in the Thirties, London: Faber and Faber, 1981.

Moseley, Ray, Mussolini's Shadow. The Double Life of Count Galeazzo Ciano, New Haven: Yale University Press 1999.

Mosley, Leonard, On Borrowed Time, London: Pan Books Ltd, 1969.

Mosse, George L., The Crisis of German Ideology: Intellectual Origins of the Third Reich, New York: Grosset and Dunlap, 1964.

Mosse, George L., "The Political Culture of Italian Futurism." Journal of Contemporary History, Vol. 25, Nos. 2/3, 1990, pp. 253-268.

Nicolai, Michela, Puccini “compositore di stato?" Strumentalizzazione di un personaggio publico durante ilfascismo, paper delivered at the International Musicological Conference "Music and Propaganda in the Short Twentieth Century”, Pistola, 18-20 May 2012.

Nicolodi, Fiamma, Musica e musicisti nel ventennio fascista, Fiesole: Discanto Edizioni, 1984.

Nicolodi, Fiamma, "Aspetti di politica culturale nel ventennio fascista." In: Italian Music, Roberto Illiano (ed.), Turnhout: Brepols, 2004, pp. 97-122.

Osmond-Smith, David, "Masculine Semiotics: The Music of Goffredo Petrassi and the Figurative Arts in Italy during the 1930s." Twentieth- Century Music, Nos. 1-2, 2012, pp. 11-37.

Painter, Karen, Symphonic Aspirations: German Music and Politics, 1900-1945, Cambridge: Harvard University Press, 2007. 
Painter, Karen, "Musical Aesthetic and National Socialism." In: Music and Dictatorship in Europe and Latin America, Roberto Illiano, Massimiliano Sala (eds.), Turnhout: Brepols, 2009, pp. 121-140.

Painter, Karen, "Polyphony and Racial Identity: Schönberg, Heinrich Berl, and Richard Eichenauer." Music and Politics, Vol. V, No. 2, Summer 2011 http:// quod.lib.umich.edu/m/mp/9460447.0005.203?view=text;rgn=main.

Paul, Catherine, "Ezra Pound, Alfredo Casella, and the Fascist Cultural Nationalism of the Vivaldi Revival." Quaderni di Palazzo Serra, 15 (2008), pp. 91-112: http://www.lcm.unige.it/ricerca/pub/15/05.pdf, accessed: 16.10.2017. Pennybacker, Susan D., From Scottsboro to Munich - Race and Political Culture in 1930s Britain, Princeton and Oxford: Princeton University Press, 2009.

Piccardi, Carlo, "La parabola di Renzo Massarani, compositore ebreo nellombra del facismo." In: Music and Dictatorship in Europe and Latin America, Roberto Illiano (ed.), Turnhout: Brepols, 2009, pp. 171-332.

Plantinga, Leon, Romantic Music, New York: Norton, 1984.

Poggesi, Marta, "Mario Pilati e l'ombra del regime." Arte, Musica e Spettacolo. Annali del dipartimento di Storia delle Arti e dello Spettacolo, Vol. V, Firenze, 2004, pp. 24-35.

Polony, Leszek, Polski kształt sporu o istotę muzyki, Kraków: Akademia Muzyczna, 1991.

Pruszyński, Mieczysław, Tajemnica Piłsudskiego, Warszawa: Polska Oficyna Wydawnicza, 1997.

Read, Donald, Edwardian England, London: Harrap, 1972.

Respighi, Elsa, Ottorino Respighi: His Life Story, trans. Gwyn Morris, London: G. Ricordi, 1962.

Riethmüller, Albrecht, "Musik, die "deutscheste" Kunst." In: Verfemte Musik: Komponisten in den Diktaturen unsers Jahrhunderts, Joachim Braun, Vladimir Kabusicky, Heidi Tamar-Hoffmann (eds.), Frankfurt am Main: Peter Lang, 1995, pp. 91-97.

Romanou, Katy, "Exchanging Rings under Dictatorships." In: Music and Dictatorship in Europe and Latin America, Roberto Illiano, Massimilliano Sala (ed.), Turnhout: Brepols, 2009, pp. 27-64.

Rothstein, William, “The Americanization of Heinrich Schenker." In: Schenker Studies, Hedi Siegel (ed.), Cambridge: Cambridge University Press, 1990, pp. 193-203.

Sachs, Harvey, Music in Fascist Italy, London: George Weidenfeld \& Nicolson, 1987. Salaris, Claudia, Artecrazia:l'ávanguardia futurista negli anni del fascismo, Firenze: La nuova Italia, 1992. 
Sandelewski, Wiarosław, Puccini, Kraków: PWM, 1973.

Sarfatti, Michele, The Jews in Mussolini's Italy: From Equality to Persecution, Madison: University of Wisconsin Press, 2006.

Schaffer, Gavin, Racial Science and British Society 1930-62, Basingstoke: Palgrave Macmillan 2008.

Schubert, Giselher, "The Aesthetic Premises of a Nazi Conception of Music." trans. Steven Lindberg and Joan Evans, In: Music and Nazism: Art Under Tyranny, 1933-1945, Michael H. Kater, Albrecht Riethmüller (eds.), Laaber: Laaber-Verlag, 2003, pp. 64-74.

Scuccimarra, Luca, "Romanità", In: Dizionario del fascismo, Victoria de Grazia, Sergio Luzzatto (eds.), Torino: Einaudi, 2002-2003, Vol. II, pp. 539-541.

Siegmund-Schultze, Walther, "Theorie und Methode des sozialistischen

Realismus in der Music." In: Handbuch der Musikaesthetik, Siegfried Bimberg (ed.), Leipzig: Deutscher Verlag für Musik, 1979, pp. 160-183.

Smith, Anthony D., National Identity, Reno-Las Vegas- London: University of Nevada Press, 1993.

Smith, Anthony D., Nationalism and Modernism, London: Routledge, 1998.

Snarrenberg, Robert, "Competing Myths: The American Abandonment of Schenker's Organicism." In: Theory, Analysis and Meaning in Music, Anthony Pople (ed.), Cambridge: Cambridge University Press, 1994, pp. 29-57.

Sponheuer, Bernd, “The National Socialist Discussion on the 'German Quality' in Music." In Music and Nazism: Art Under Tyranny, 1933-1945, Michael H. Kater, Albrecht Riethmüller (eds.), Laaber: Laaber-Verlag, 2003, pp. 32-42.

Steinweis, Alan E., Art., Ideology and Economics in Nazi Germany: The Reich Chambers of Music, Theater, and the Visual Arts, North Carolina: University of North Carolina Press, 1993.

Stone, Maria S., The Patron State: Culture and Politics in Fascist Italy, New Jersey: Princeton University Press, 1998.

Strzelecki, Paweł, "Nowy romantyzm" w twórczości kompozytorów polskich po roku 1975, Kraków: Musica Iagellonica, 2006.

Studdert, Will, "'Happy Hour in the Afternoon' and 'Station Debunk': Two Nazi Jazz Projects of World War II." In: Music and Propaganda in the Short Twentieth Century, Massimiliano Sala (ed.), Turnhout: Brepols, 2014, pp. 37-56.

Studdert, Will, "'Happy Hour in the Afternoon' and 'Station Debunk': Two Nazi Jazz Projects of World War II." In: Music and Propaganda in the Short Twentieth Century, Massimiliano Sala (ed.), Turnhout: Brepols, 2014.

Taruskin, Richard, “The Dark Side of the Moon.” In: The Danger of Music and Other Anti-Utopian Essays, Los Angeles: University of California Press, 2009, pp. 202-216. 
Taruskin, Richard, “Can We Give Poor Orff a Pass at Last?” In: The Danger of Music and Other Anti-Utopian Essays, Taruskin (ed.), Los Angeles: University of California Press, 2009, pp. 161-167.

Taruskin, Richard, “Alte Musik' or 'Early Music'?” Twentieth-Century Music, Cambridge University Press, Vol. 8, No. 1, 2011, pp. 3-28.

Taylor, Alan J. P., English History 1914-1945, Oxford: Oxford University Press 1975.

Tempesti, Fernando, Arte dell'Italia fascista, Milano: Feltrinelli, 1976.

Ternon, Yves and Helman, Socrate, Histoire de la Medecine SS ou le mythe du racisme biologique, Tournai: Casterman, 1969.

Tolbert, Elizabeth, "Music and Meaning: An Evolutionary Story." Psychology of Music, 2001, Vol. 29, No. 1, pp. 84-94.

Trevelyan, George M., A Shortened History of England, Harmondsworth: Penguin Books Ltd, 1981.

Trochimczyk, Maria, "W stronę muzykologii narodowej: muzykolodzy wobec muzyki polskiej." Muzyka, Vol. 47, Nos. 3-4, pp. 129-143.

Trzęsiok, Marcin, "Narodziny dodekafonii z ducha teozofii - Schönberg, Swedenborg i metempsychoza." In: Kompozytor i jego swiat- Bronisław Przybylski in memoriam, Ewa Zając, Marta Szoka (eds.), Łódź: Akademia Muzyczna im. G.K. Bacewiczów, 2012, pp. 39-56.

Tsagkarakis, Ioannis, The Politics of Culture: Historical Moments in Greek Musical Modernism Vol. I, PhD diss, Royal Holloway University of London, 2013, https://pure.royalholloway.ac.uk.

Tuchowski, Andrzej, "Narodowy a uniwersalny wymiar muzyki w świetle refleksji estetycznej Ralpha Vaughana Williamsa a Karola Szymanowskiego." In: Karol Szymanowski w perspektywie kultury muzycznej przeszłości i współczesności, Zbigniew Skowron (ed.), Kraków: Musica Iagellonica; Warszawa: Institute of Musicology of the University of Warsaw, 2007, pp. 49-78.

Tuchowski, Andrzej, "Music Analysis in the Light of National Traditions." In: Analiza dzieła muzycznego, Anna Granat-Janki (ed.), Wrocław: Akademia Muzyczna im. K Lipińskiego, 2014, pp. 169-185.

Tuchowski, Andrzej, "Racism in Nazi Historiography and Concepts of Music Theory." In: Nationality vs. Universality: Music Historiographies in Central and Eastern Europe, S. Żerańska-Kominek (ed.), Cambridge: Cambridge Scholar Press, 2016, pp. 212-238.

Turba, Allessandro, Il mito di Giulio Cesare e il culto della romanità nel teatro musicale dell'Era Fascista: i casi di Gian Francesco e Riccardo Malipiero, PhD diss., Universita degli studi di Milano, 2016. file://C:/Users/Dell/Downloads/ phd_unimi_R10055.pdf. Accessed: 01.12.2018. 
Vaughan Williams, Ursula, A Biography of Ralph Vaughan Williams, Oxford: Oxford University Press, 1992.

Versari, Maria E., "Futurist Machine Art, Constructivism, and the Modernity of Mechanization." In: Futurism and the Technological Imagination, Günter Berghaus (ed.), Amsterdam: Rodopi, 2009, pp. 149-170.

Vitzhum, Thomas S., Nationalismo e Internazionalismo - Ottorino Respighi, Alfredo Casella und Gian Franco Malipiero und die kultururplitischen Debatted zwischen 1912 und 1938 in Italien, PhD diss, Regensburg University, 2007, https://epub.uni-regensburg.de/10768/1/Dissertation_Vitzthum.pdf, accessed 10.12.2018.

Walicki, Andrzej, Philosophy and Romantic Nationalism. The Case of Poland, Oxford: Oxford University Press, 1982.

Walicki, Andrzej, Naród, nacjonalizm, patriotyzm, Kraków: Universitas, 2009.

Wapiński, Roman, Historia polskiej mysli politycznej XIX i XX wieku, Gdańsk: ARCHE, 1997.

Wiatr, Jerzy J., Zagadnienia rasowe w socjologii amerykańskiej, Warszawa: PWN, 1959.

Wightman, Alistair, "Szymanowski’s Writing on Music - A Comparative Study." Res facta, No. 9, 1982, pp. 18-49.

Wójtowicz, Ewa, “'Muzyka nie jest kosmopolityczna’ - Ludomira Michała Rogowskiego myśli o muzyce narodowej." In: Karol Szymanowski w perspektywie kultury muzycznej przeszłości i wspótczesności, Zbigniew Skowron (ed.), Kraków-Warszawa: Musica Iagellonica, 2007, pp. 79-92.

Wolff, Elizabeth C., "Biological Racism and Antisemitism as Intellectual Construction in Italian Fascism: The Case of Telesio Interlandi and 'La difesa della razza." In: Racial Science In Hitler's Europe 1938-1945, Roy Yeomans, Anton Weiss-Wendt (eds.), Lincoln and London: University of Nebrasca Press, 2013, pp. 175-199.

Wulf, Josef, Musik im Dritten Reich: Eine Dokumentation, Frankfurt am Main: Ullstein Verlag, 1983.

Young, Percy M., A History of British Music, London: Ernst Benn, 1967. 


\section{Index}

A

Acerbo, Giacomo 205

Adams, Byron 32, 37, 239

Addinsell, Richard 189

Alaimo, Vincenzo 194, 239

Alexander I (Tzar of

Russia) 176, 217

Alfano, Franco 179, 183

Arendt, Hannah 18, 83, 215, 239

Arulenus, Rusticus 108

Assmann, Jan 172, 239

Atterberg, Kurt 88-90

Auden, Wystan Hugh 150, 233

B

Bach, Johann Sebastian 28, 35, 43, $62,65,66,75,77,93,97,125,156$, 202, 203, 223-225

Bailey, Robert Warren 84, 239

Balicki, Zygmunt 9, 10, 12, 216, 230, 233

Barańczak, Stanisław 217

Barkan, Elazar 141, 142, 239

Bartok, Bela 42, 48

Bastianelli, Gianotto 182-184, 186, 233, 234

Bastias, Costas 211

Bax, Arnold 26

Beck, Józef 132, 162

Beecham, Thomas 145

Beethoven, Ludwig van 24, 28, 33, $65,66,79,90,95,96,118,127$, 221, 223, 224, 240

Bell, Michael 138-141, 233

Bellini, Vincenzo 79

Bent, Ian 75, 239

Bèrard, Carol 88

Berg, Alban 170

Berghaus, Günther 167, 248
Berl, Heinrich 65, 67-69, 74, 117, $122,126,233,245$

Berlioz, Hector 224

Berry, David C. 226, 239

Bilica, Krzysztof 176, 240

Bimberg, Siegfried 218, 238, 246

Bizet, Georges 118, 120

Blessinger, Karl 58, 59, 70-77, 79, $80,96,233$

Bliss, Arthur 26, 145

Bossi, Renzo 183

Bottai, Giuseppe 200

Bourdieu, Pierre 94, 223, 240

Brahms, Johannes 28, 29, 66, 90, 96, 97, 202, 221, 224

Braun, Joachim 58, 69, 242, 245

Brecht, Bertolt 218

Bresgen, Cesar 97

Britten, Benjamin 19, 25, 48, 49, 148-154, 175, 229, 240, 244

Brod, Max 121

Brooks, Geoffrey 95, 238

Broszat, Martin 51, 83

Brown, Julie 199, 243

Bruch, Max 29, 140, 183

Bruckner, Anton 95, 96

Brückner, Hans 70, 237

Bruno, Giordano 123

Brzeziński, Zbigniew 83, 241

Brzękowski, Jan 168

Buch, Esteban 97, 241

Budden, Julian 175, 176, 240

Busoni, Feruccio 187

Bychowski, Gustaw 225, 240

C

Caesar Julius Gaius 166, 169, 186, 207

Calmettes, Joël 158

Camrose, William Berry 52 
Capell, Richard 170, 233

Caplicka, John 172

Carlyle, Thomas 21, 59

Carpenter, Humphrey 154, 240

Casella, Alfredo 168, 170, 182, 183, 207, 245, 248

Cassina, Wolff Elizabeth 199, 200

Castelnuovo-Tedesco, Mario 206

Chamberlain, Houston Stewart 52, $55,56,59,61,70,146,154,196$, 205,233

Chamberlain, Neville 133, 149

Charlemagne (Charles the Great) 34

Carpenter, Humphrey 154, 240

Chase, Gilbert 137, 138, 176, 233

Cherubini, Luigi 162

Chomiński, Józef Michał 110, 242

Chopin Fryderyk 12, 13, 15, 22-24, $26,34,42,75,81,118,126-133$, $223,230,236,239$

Chopin, Nicolas 130

Chybiński, Adolf 110

Chylińska, Teresa 26, 38-40, 53, 238, 242

Ciano, Galeazzo 161, 162, 199, 244

Ciesielski, Rafał 105, 106, 240

Cieszkowski, August 231

Claus, Ludwig Ferdinand 63, 141, 159, 233

Cobbe, Hugh 29, 46, 47, 144, 240

Cogni, Giulio 199-205, 233

Cooke, Arnold 170, 233

Cortot, Alfred 135

Coser, Lewis A. 172, 242

Crompton, Louis 24, 238

Czartoryski, Adam Jerzy 231

Czekalski, Tadeusz 209, 240

Czekanowska, Anna 42, 242

Czekanowski, Jan 104, 122, 233

D

Dahlhaus, Carl 36, 37, 100, 219-221, 233, 234, 240
Dallapicola, Luigi 169, 184, 206, 212, 213, 234, 241

Danek, Danuta 225, 240

Darwin, Charles 37, 55, 62, 123, 147

Davies, Norman 83

Debussy, Claude 183, 221

Delius, Frederic 187

Dennis, David B. 84, 96, 100, 240

Dent, Edward J. 170

Depero, Fortunato 166

Dermo, Maiken 220, 234

Dickens, Charles 150

Diederichs, Eugen 54

Dmowski, Roman 10-12, 22, 107-109, 111, 161, 216, 234, 244

Donadoni, Omodeo Miriam 184, 234

Donizetti, Gaetano 162

Dümling, Albrecht 84, 240

Dunstable, John 125

Dziadek, Magdalena 41, 106, 109, 110,240

Dziębowska, Elżbieta 60

E

Earl, Ben 169, 207

Eichenauer, Richard 61, 63-65, 104, $126,131,133,134,201,203-205$, $234,236,237,239,245$

Einem, Gottfried von 99

Einstein, Alfred 16, 123, 134, 136, 215,234

Eisler, Hans 218

Elgar, Edward 145, 175, 224

Eliot, Thomas Stearns 156

Elsner, Józef 223

Emmanuel, Maurice 92

Enescu, George 183

Engels, Friedrich 218

Erdlen, Hermann 97

Erhardt, Ludwik 101, 170, 241

Evans, Joan 89, 99, 101, 241, 246 


\section{F}

Fauré, Gabriel 183

Fellini, Federico 186, 187

Finck, Heinrich 66

Fitelberg, Grzegorz 113

FitzGibbon, Katharine 97, 241

Flamm, Christoph 179, 180, 185, 189, 234, 237, 241

Fleetwood, Nancy 98, 136, 137, 139, 179,234

Forte, Allen 226

Freud, Siegmund 141, 225

Friedman, Ignacy 81

Friedrich, Carl Joachim 83, 241

Froberger, Johann 66

Frogley, Alain 27-29, 32, 239, 240, 241

Fromm, Erich 56, 67, 241

Fubini, Enrico 195

Fuhrmann, Heinz 100, 234

Funk, Walther 87-89, 94, 137

Furtwängler, Wilhelm 88

G

Gabrieli, Antionio 118, 134

Geisler, Ursula 84, 241

Galilei, Galileo 123

Galilei, Vinzenzo 195

Garberding, Petra 88, 89, 237, 238, 241

Garibaldi, Giuseppe 162

Gasco, Alberto 179, 180, 234

Gates, Reginald 142

Gellner, Ernest 13, 47, 225, 241

Gentile, Giovanni 164

Gerigk, Herbert 70, 73, 100, 235, 236, 238

Gerlach, Kurt 63, 235

Germino, Dante L. 199, 241

Gershwin, George 189

Giardina, Andrea 163, 197, 199, 207, 242

Gilette, Aaron 199, 242
Gioberti, Vincenzo 197

Girth, Peter 84, 240

Gluck, Christoph Willibald 62, 134

Gnessin, Mikhail 122

Gniadek, Stanisław 164, 236

Gobineau, Joseph Arthur de 55, 56, 196, 235

Goebbels, Joseph 78, 84-87, 94, 99, $101,102,136,155,158,159,169$, 211, 235

Goethe, Johann Wolfgang 223

Goldbeck, Fred 92, 235

Gołąb, Maciej 17, 75, 110, 216, 223, 230, 242

Göring, Hermann 153

Grabowski, Zygmunt 104-106, 235

Graf, Otto 85, 91, 94, 235

Granat-Janki, Anna 219, 247

Grazia, Victoria de 172, 246

Grazzi, Emanuele 212

Grigson, Geoffrey 150, 233

Grobler, Adam 15, 16

Gross, Walter 58, 59, 235

Grunberger, Richard 58, 67, 242

Grynberg, Karol 143, 242

Grynszpan, Herszel 153-155, 158, 159,243

Günther, Hans 57, 63, 64, 131, 199, 200, 235

$\mathrm{H}$

Haddon, Alfred Cort 142, 235

Halbwachs, Maurice 172, 242

Halczak, Bogdan 53, 242

Hanau, Ewa 69, 242

Handel, George Friedrich 24, 125, 156,225

Hänel, Wolfgang 51

Hanslick, Edward 62, 71, 74, 144

Haydn, Joseph 93, 224

Hegel, Georg Wilhelm Friedrich 13, $28,34,223$

Heine, Heinrich 119 
Helgason, Hallgrimur 98, 242

Helman, Socrate 57, 247

Helman, Zofia 33, 39, 42, 106, 240, 242

Henderson, Neville 52, 235

Herder, Johann Gottfried 28, 34, 195

Herennius, Senecio 108

Herold, Ferdinand 79

Herz, Henri 72

Hilberg, Frank 86

Himmler, Heinrich 57, 158, 201

Hindemith, Paul 88, 91, 170

Hitler, Adolf 51-53, 55, 56, 83-85, 93-95, 99, 108, 112, 113, 133, 134, $136,140,141,143,146,149,153$, 154, 165-169, 199, 201, 209, 238, 241, 243, 248

Hlond, August 110, 111, 112, 114, 115,235

Hobsbawm, Eric J. 22, 23, 27, 242

Hoffmann, Ernst Theodor

Amadeus 58, 120, 245

Holst, Gustav 30, 32

Homer 33, 35

Horace 174

Hoss, Phoebe 15, 244

Horthy, Miklos 18

Howes, Frank 47

Huberman, Bronisław 135

Hünten, Franz 72

Huntington, Elsworth 142, 235

Husserl, Edmund 67, 68

Huxley, Julian 142, 235

Hynes, Samuel 134, 147, 148, 243

I

Illiano, Roberto $73,170,179,194$, 199, 201, 209, 239, 241, 243, 244, 245

Interlandi, Telesio 199-201, 248

Isherwood, Chrostopher 148
J

Jachimecki, Zdzisław 39

Jadassohn, Salomon 119, 183

Janaček, Leoš 98

John Paul II (the Pope) 216

Jonca, Karol 153, 155, 156, 243

Jung, Carl Gustav 151, 156, 158

K

Kalinowski, Witold 58

Kalomiris, Manolis 210-212

Kapelański, Maksymilian 188

Karłowicz, Mieczysław 12, 24, 47, 48, 182, 184

Kater, Michael Hans 85-87, 89, 96, 99-102, 243, 244, 246

Keller, Hans 49

Kennedy, Michael 30, 45

Kerman, Joseph 223, 243

Kienzl, Wilhelm 88

Klemperer, Otto 135, 146

Kochański, Paweł 113

Kohler, Andrew S. 100, 102, 234, 243

Köhler, Joachim 55, 243

Kohn, Hans 10, 11, 21, 27, 28, 147, $164,229,243$

Korolec, Jan 107, 235

Koryś, Piotr 10

Król, Marcin 172

Krzyżanowska, Justyna 129

L

Lagarde, Paul de 54, 236

Lammers, Hans 86

Landra, Guido 198, 200, 201

Langbehn, Julius 54, 73, 236

Leifs, Jon 97, 98, 242

Lenin, Vladimir 218

Levi, Erik 45, 94, 136, 143, 145, 146, 225,243

Lévi-Strauss, Claude 15, 52, 143, 145,244 
Libelt, Karol 13, 14, 23, 231, 236

Lipiner, Siegfried 120

Lipski, Józef 112, 113

Lissa, Zofia 123-127, 129-132, 236

Liszt, Ferenc 34, 42, 118

Lockspeiser, Edward 134, 236

Lorenz, Konrad 64

Lualdi, Adriano 88

Ludwig, Emile 103, 236

Luther, Martin 195

Lutosławski, Witold 25, 93, 229

Luzzatto, Sergio 172, 246

\section{M}

Macaluso, Alessia Angela

E. 190,244

Maffina, Gianfranco 194, 244

Mahler, Gustav 54, 66, 69, 73, 74, 77, $79,113,115,118-122,140,185,224$

Malipiero, Gian Francesco 169, 173, 179, 182, 183, 247, 248

Malvano, Laura 163, 244

Mann, Heinrich 58, 119

Mann, Thomas 58, 108

Marchand, Louis 35

Marczyńska-Negri, Jadwiga 190

Marinetti, Filippo

Tommaso 166-168

Martin, Benjamin G. 201, 244

Marx, Adolf Bernhard 74

Marx, Karl 218

Marylski, Antoni 114-116, 236

Mascagni, Pietro 166, 173, 184, 194

Massaka, Iwona 95

Massarani, Renzo 194, 206, 245

Matzke, Hemann 59-64, 71, 75, 126, 203, 204, 236

Mazzini, Giuseppe 231

McClatchie, Stephen 86, 244

Meissner, Max 105, 135, 179, 236

Melchiorre, Nicola 180-182, 185, 186, 236
Metaxas, Ioannis 209, 210, 212

Meyer, Krzysztof 216

Meyerbeer, Giacomo 73, 76, 77, 79, $119,120,140$

Micewski, Andrzej 109, 244

Michahelles, Ernesto (Thayaht) 166

Michałowski, Kornel 24, 26, 41-44, 238

Mickiewicz, Adam 22, 162, 231

Mierczyński, Stanisław 110

Mieses, Mateusz 128-130, 236

Milton, John 34

Mitchell, Donald 151, 244

Mochnacki, Maurycy 13, 22, 217, 236

Mommsen, Theodor 195

Moniuszko, Stanisław 48

Monteverdi, Claudio 184

Moore, George Edward 37

Morris, Gwyn 189, 245

Moseley, Ray 161, 244

Mosley, Leonard 52, 112, 155, 244

Mosley, Oswald 52

Mosse, George Lachmann 53, 54, $56,67,73,166,244$

Motte-Haber, Helga de la 220, 234

Mozart, Wolfgang Amadeus 62, 66, $79,90,93,127,221,223,224$

Müller, Gottfried 97, 241

Müller, Rolf-Dieter 113

Müller-Blattau, Josef 66, 80, 236

Murray, Gilbert 33

Mussolini, Benito 164, 213, 236

Mussolini, Romano 165, 178, 179, 209, 210, 212

Mussorgsky, Modest 34, 48, 118

Myaskovsky, Nicolai 93

$\mathbf{N}$

Navickaite, Lina 222

Neugroschel, Joachim 15, 244

Neusiedler, Hans 118 
Nice, Richard 223, 240

Nicolai, Michela 177, 217, 244

Nicolodi, Fiamma 170, 190, 244

Nietzsche, Friedrich 59, 69

Noskowski, Zygmunt 41

Nott, Josiah Clark 16

Nowaczyński, Adolf 162, 163, 237

O

Octavian, Augustus (Roman emperor) 169

Oboussier, Robert 89, 237

Offenbach, Jacques 77, 118, 120

Omodeo, Miriam

Donadoni 184, 234

Orff, Carl 93, 99-102, 168, 171, 235, 243, 247

Orwell, George 148

Osmond-Smith, David 167, 168, 244

Otręba, Bolesław 143, 242

Owen, Wilfred 148, 156

$\mathbf{P}$

Paderewski, Ignacy Jan $12,111,127$, 132, 237

Painter, Karen 65, 73, 83-85, 95-97, 168, 193, 244, 245

Paladino, Franco 165, 237

Palester, Roman 229

Palestrina, Giovanni Pierluigi 64

Parry, Hubert 28, 34

Paul, Catherine 182, 245

Pauman, Conrad 66

Penderecki, Krzysztof 93, 216

Pennybacker, Susan D. 134, 135, 141, 245

Pessenlehner, Robert 58, 59, 61, 65, 66, 237

Petrassi, Goffredo 167, 190, 244

Pfitzner, Hans 69, 97, 100

Piccardi, Carlo 194, 206, 245

Pilati, Mario 73, 202, 245
Piłsudski, Józef 18, 108, 109, 112, 245

Piotrowska, Maria 224

Pirandello, Luigi 166

Pisacane, Carlo 197

Pizzetti, Ildebrando 179, 183

Plantinga, Leon 27, 245

Podwysocka, Magdalena 95

Poggesi, Marta 202, 245

Poliński, Aleksander 41

Polony, Leszek 42, 245

Ponchielli, Amilcare 162

Pople, Anthony 226, 246

Porfino, Ennio 173

Prampolini, Enrico 166-168

Prokofiev, Siergei 48, 93

Prosnak, Karol Mieczysław 106

Pruszyński, Mieczysław 108, 245

Przybyszewski, Stanisław 12, 184, 237

Puccini, Antonio 212

Puccini, Giacomo 171, 173-178, 183, 187, 212, 240, 244, 246

Pessenlehner, Robert 58, 59, 61, 65, 66, 237

Poliński, Aleksander 41

Pound, Ezra 182, 245

Przybyszewski, Stanisław 12, 184, 237

Purcell, Henry 34

$\mathbf{R}$

Raabe, Peter 59, 101, 139, 140, 237

Rachmaninov, Sergei 122, 219

Rath, Ernst von 155, 159

Raynor, Henry B. 138, 237

Rausching, Herman 51

Rauter, Ferdinand 46, 49

Ravel, Maurice 30-32, 48, 92, 144, $155,177,178,183,186,187$, 196, 210

Read, Donald 22, 245 
Regamey, Konstanty 33

Reiss, Józef 14, 114, 116-122, 142, 237

Renan, Ernst de 22

Rensis, Raffaello de 165, 237

Respighi, Elsa 189, 245

Respighi, Ottorino 19, 90, 173, 178-191, 206, 230, 234, 236, 241, 245,248

Reti, Rudolf 222, 227

Reusch, Fritz 57, 59, 62, 71, 78, 237

Ribbentrop, Joachim von 112, 143, 145,242

Riethmüller, Albrecht 58, 86, 89, 96, 244, 245, 246

Rieti, Vittorio 206

Rimsky-Korsakov, Nicolai 118, 122, 182,183

Rock, Christa 70, 237

Rogowski, Ludomir Michał 42, 248

Romanou, Katy 209, 210-212, 245

Rosenberg, Alfred 57, 71, 84, 99, 101

Rossi, Nino 179, 237

Rossi, Salomone 118

Rossini, Gioacchino 79, 162

Rothgeb, John 226

Rothstein, William 225, 226, 245

Różycki, Ludomir 106

Rubinstein, Anton 113, 118, 120

Rubinstein, Artur 128, 219, 221

Russell, Bertrand 28, 37

Russel, Thomas A. 140, 237

Russolo, Luigi 193, 194, 244

S

Sachs, Harvey 178, 245

Sachs, Julius 81, 238

Sala, Massimiliano 73, 78, 94, 199, 201, 209, 213, 234, 243, 245, 246

Salaris, Claudia 168, 245

Salvaneschi, Nino 132
Salvatori, Fausto 174

Samson, Jim 225

Sandelewski, Wiarosław 171, 246

Sarfatti, Michele 198, 246

Saryusz-Wolska, Magdalena 172, 239

Scarlatti, Domenico 75, 223, 239

Schaffer, Bogusław 191

Schaffer Gavin 141, 246

Schubert, Giselher 89, 246

Schubert, Franz 29, 90, 221

Scuccimarra, Luca 172, 246

Scheding, Florian 225

Schemann, Ludwig 64, 238

Schenker, Heinrich 75, 222-226, 239, 245, 246

Schering, Arnold 66

Schlegel, Friedrich 195

Schleiermacher, Friedrich 36

Schönberg, Arnold 29, 48, 65, 69, $72,73,99,102,121,140,168$, $170,222,224,225,227,230,238$, 245, 247

Schopenhauer, Arthur 184

Schroeder, Christa 95, 238

Schubert, Franz 29, 89, 90, 221, 246

Schulze-Naumburg, Paul 64, 238

Schumann, Otto 29, 66, 79, 88, 224

Schumann, Robert 119

Schutz, Heinrich 134

Scriabin, Alexander 122, 184

Shaw, George Bernard 24, 238

Shostakovich, Dmitri 93, 102, 122, 153, 189

Shkliar, Ephraim 122

Shirer, William L. 95

Sholokhov, Mikhail 218

Sibelius, Jean 98, 145

Siegel, Hedi 225, 245

Siegmund-Schultze, Walther 218, 238, 246

Silva, Manuel Deniz 97, 241 
Simon, John 52

Sitt, Hans 183

Skowron, Zbigniew 21, 42, 247, 248

Smith, Anthony David 9, 22, 23, 46, 47, 49, 246

Snarrenberg, Robert 226, 246

Sokorski, Włodzimierz 215

Sousa, John Philip 175

Speer, Albert 95

Spohr, Ludwig 79

Sponheuer, Bernd 94, 95, 246

Stalin, Josef Vissarionovich 83, 151, 165,215

Stege, Fritz 86, 89, 90, 93, 94, 96, 98-100, 238

Stein, Leonard 99, 238

Steinweis, Alan E. 84, 246

Stengel, Theo 70, 236, 238

Stęszewski, Jan 70

Stevens, Robert 138, 237

Stone, Marla Susan 177

Strauss, Richard 86, 88, 100, 118, $139,143,145,184$

Stravinsky, Igor 42, 48, 99-102, 122, $170,178,181,184,241$

Strzelecki, Paweł 217, 246

Stuckenschmidt, Hans

Heinz 86, 171

Studdert, Will 78, 246

Sullivan, Arthur Randall 34

Swingler, Randall 152, 153

Szoka, Marta 222, 247

Szymanowski, Karol 12, 19, 21, 24-26, 28-32, 36-45, 47-49, 53, $67,90,106,110,113-116,132$, $170,173,184,186,229,238,240$, $242,247,248$

T

Taine, Hippolyte 42

Tallis, Thomas 31, 34

Tansman, Aleksander 33
Tarasti, Eero 222

Taruskin, Richard 100, 179, 224, 225, 246, 247

Taylor, A.J.P. 140, 141, 149, 247

Taylor, Ronald 55, 243

Tchaikovsky, Pyotr 122, 219-221, 224

Ternon, Yves 57, 69, 247

Tempesti, Fernando 165, 247

Thayaht, Ernesto 166, 167

Thomson, Dorothy 158

Tieck, Ludwig 36, 58

Tippett, Michael 19, 149-151, 154-156, 158, 238

Tolbert, Elizabeth 220, 247

Toni, Alcesto 183

Tomaszewski, Mieczysław 176, 240

Torrefranca, Fausto 171, 183, 184

Toscanini, Arturo 135, 206

Towiański, Andrzej 22

Trochimczyk, Maria 218, 247

Trzęsiok, Marcin 222, 247

Tsagkarakis, Ioannis 210, 211, 247

Twardowski, Kazimierz 126

Turba, Allessandro 173, 247

V

Vaughan Williams Ursula 146

Vaughan, Williams Ralph 19, 21, 23, $24,25,27,122,143,144,187,238$, 239, 241, 247, 248

Versari, Maria Ellena 167, 248

Visco, Sabato 201

Vitzhum, Thomas Sebastian 248

W

Walicki, Andrzej 11, 248

Walker, Alan 227

Walldorf, Jerzy 239

Walter, Bruno 146

Walton, William 48, 145

Wapiński, Roman 107, 109, 161, 248 
Washbourne, Christopher 220, 234

Waterhouse John C.G. 184

Waterhouse, Janet 191

Wiatr, Jerzy Józef 16, 248

Wieczorek, Sławomir 218

Weiss-Wendt, Anton 248

Wieniewski, Ignacy 108, 239

Wightman, Alistair 39, 45, 242, 248

Władysław II Jagiełło (King of Poland) 14

Władysław IV Waza (King of Poland) 14

Wójcik-Kepreulian, Bronisława 104, 116,239

Wójtowicz, Ewa 42, 248

Woltmann, Ludwig 196, 239
Woytowicz, Bolesław 189

Wulf, Josef 96, 238, 248

Y

Yeomans, Roy 199, 248

Young, Percy M. 28, 248

$\mathbf{Z}$

Zając, Ewa 222, 247

Zbyszewski, Karol 198, 239

Zieliński, Tadeusz A. 224

Zubillaga, Igor Contreras 97, 241

Zumsteeg, Johann Rudolf 79

Zerańska-Kominek, Sławomira 51

Zweig, Stephan 86

Zychowicz, Piotr 112 



\title{
Eastern European Studies in Musicology
}

\author{
Edited by Maciej Gołąb
}

Vol. 1 Paweł Gancarczyk / Lenka Hlávková-Mráčková / Remigiusz Pośpiech (eds.): The Musical Culture of Silesia before 1742. New Contexts - New Perspectives. 2013.

Vol. 2 Laura Vasiliu/Florin Luchian/Loredana laţeşen/Diana-Beatrice Andron (eds.): Musical Romania and the Neighbouring Cultures. Traditions-Influences-Identities. Proceedings of the International Musicological Conference July 4-7, 2013, Iaşi (Romania). 2014.

Vol. 3 Barbara Przybyszewska-Jarmińska: Marcin Mielczewski and Music under the Patronage of the Polish Vasas. Translated by John Comber. 2014.

Vol. 4 Tomasz Jasiński: The Musical Rhetoric of the Polish Baroque. Translated by Wojciech Bońkowski. 2015.

Vol. 5 Bogusław Raba: Between Romanticism and Modernism. Ignacy Jan Paderewski's Compositional CEuvre. Translated by John Comber. 2015.

Vol. 6 Maciej Gołąb: Musical Modernism in the Twentieth Century. Translated by Wojciech Bońkowski. 2015.

Vol. 7 Wojciech Bońkowski: Editions of Chopin's Works in the Nineteenth Century. Aspects of Reception History. 2016.

Vol. 8 Ivana Perković / Franco Fabbri (eds.): Musical Identities and European Perspective. An Interdisciplinary Approach. 2017. 
Vol. 9 Bożena Muszkalska (ed.): The Kolbergs of Eastern Europe. 2018.

Vol. 10 Renata Tańczuk / Sławomir Wieczorek (eds.): Sounds of War and Peace. Soundscapes of European Cities in 1945. 2018.

Vol. 11 Tomasz Jeż: The Musical Culture of the Jesuits in Silesia and the Kłodzko County (1581-1776). 2019.

Vol. 12 Magdalena Walter-Mazur: Musical Culture of Polish Benedictine Nuns in the 17th and 18th Centuries. 2018.

Vol. 13 Andrzej Tuchowski: Nationalism, Chauvinism and Racism as Reflected in European Musical Thought and in Compositions from the Interwar Period. 2019.

www.peterlang.com 